\title{
ANTROPOLOGÍA Y METANTROPOLOGÍA \\ EN ABELARDO LOBATO: \\ Nuevo horizonte de comprensión del humanismo cristiano en el contexto universitario.
}

Universitat Abat Oliba CEU

FACULTAT DE CIÈNCIES SOCIALS

Programa de doctorado en Estudios Tomísticos

Departamento de Humanidades y Ciencias de la Educación 
En verdad uno tiene muchos profesores, pero no muchos maestros.

ABELARDO LOBATO.

La gloria del maestro es la vida honesta del discípulo.

SANTO TOMÁS DE AQUINO. 


\section{Resumen}

En este trabajo de investigación se expone la vida y obra del pensador dominico Abelardo Lobato Casado. Así mismo, trata de la originalidad de su propuesta antropológica llamada metantropología, en virtud de su fundamentación metafísica, del humanismo cristiano como horizonte de su pensamiento y de los olvidos radicales de la cultura moderna, a saber: el olvido del ser, el olvido de Dios, el olvido del alma, el olvido de la verdad y el olvido de la virtud. Se describe la cultura actual como una cultura sin pedagogos y referentes. Además se promueve un desarrollo del pensamiento lobatiano en el contexto de la Universidad Santo Tomás de Colombia en orden a conocer lo que caracteriza la cultura universitaria, sus desafíos y retos en el siglo XXI. En efecto, se llega a la conclusión de que la universidad en el presente siglo debe caracterizarse por ser facientes humanitatis, es decir, hacedora de humanidad. De igual manera el gran reto y desafío de la universidad es la formación humanista integral que promueva al hombre: hacer del hombre plenamente hombre. La Universidad Santo Tomás ha de seguir fortaleciendo el humanismo cristiano desde la perspectiva encarnacional como clave de la formación humanista integral.

\section{Abstract}

This research presents the life and work of the Dominican thinker Abelardo Lobato Casado. This paper deals with the originality of his anthropological proposal tittled metanthropology, based on his metaphysical foundation, by means of Christian humanism as a horizon of his thinking and of the radical forgetfulness of modern culture: the forgetfulness of being, the forgetfulness of God, the Forgetfulness of the soul, the forgetfulness of the truth and the forgetfulness of virtue. Current culture is described as a culture without pedagogues and referents. In addition, Lobatian thought is developed in the context of Saint Thomas University in Colombia in order to understand about the characteristics of the university culture, its challenges for the 21 st century. In fact, it is concluded that the university, in the updated century, must be characterized asfacientes humanitatis, that is to say, the universtiy must become in a maker of humanity. Likewise, the great challenge of the university is to offer an integral humanist formation that promotes man and make man fully man. Saint Thomas must continue to strengthen Christian humanism from an incarnational perspective as a key to an integral humanist formation.

\section{Palabras claves}

Abelardo Lobato - Metantropología - Formación - Tomismo - Humanismo Cristiano - Integralidad

Abelardo Lobato - Metanthropology - Formation - Thomism - Christian Humanism - Integrality 


\section{SUMARIO}

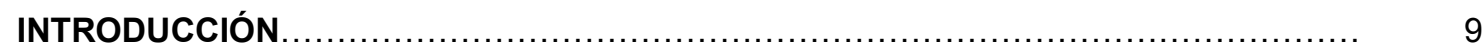

CAPÍTULO I: PRESUPUESTOS FUNDAMENTALES DEL PENSAMIENTO LOBATIANO.. 13

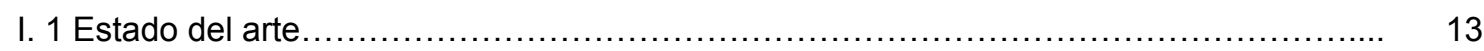

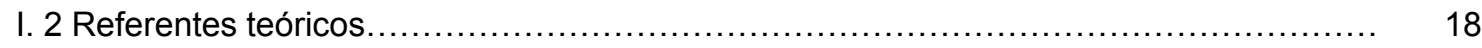

I. 3 Insumos fundamentales del pensamiento tomista que inciden en la respuesta lobatiana ante los olvidos de la cultura actual................................................................ 25

CAPÍTULO II. ESTADO DE LA CUESTIÓN................................................. 33

II. 1. La cultura contemporánea: una cultura sin pedagogos.................................. 33

II. 2. Las desventuras de una cultura sin pedagogos......................................... 38

CAPÍTULO III. TAMIZAJE BIO-BIBLIOGRÁFICO DE ABELARDO LOBATO................. 47

III. 1 Abelardo: la vida de un humanista y tomista........................................ 47

III. 2 Las principales líneas de interés e investigación del pensamiento lobatiano............... 57

III. 2. 1 La categoría 'Tomismo'........................................................... 60

III.2.2 Categoría 'Metafísica' .................................................................... 68

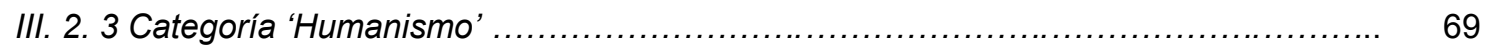

III. 2. 4 Categoría 'Antropología'............................................................. 70

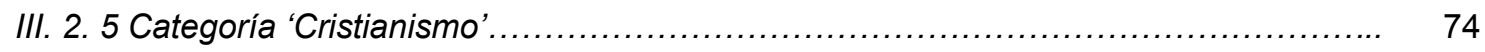

III. 2. 6 Categoría 'Dominicanismo' ........................................................... 77

III. 2. 7 Categoría 'Anotaciones' .......................................................... 78

III. 2. 8 Categoría 'Apuntes de clase'...................................................... 80

III. 2. 9 Categoría 'Conferencia'......................................................... 81

CAPÍTULO IV METANTROPOLOGÍA EN ABELARDO LOBATO......................... 85

IV. 1 La incidencia de Tomás de Aquino en Abelardo Lobato ..................................... 85

IV. 1. 1 Tomás de Aquino como humanista............................................. 85

IV. 1. 2 El humanismo en el pensamiento tomista....................................... 89

IV. 1. 3 La antropología tomista............................................................ 91

IV. 1. 4 El hombre es por naturaleza animal político y social............................... 96

IV. 1. 5 La familia humana.................................................................. 98

IV. 1.6 El conocimiento del hombre .......................................................... 99

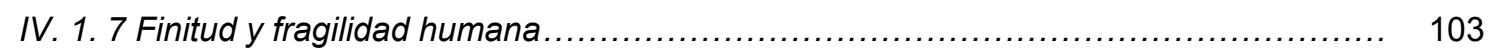

IV. 1. 8 La persona humana.................................................................... 105

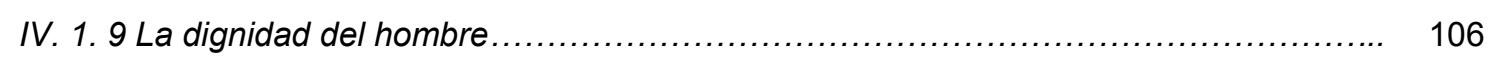

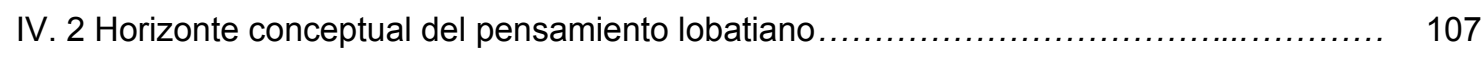


IV. 2. 1 Las vías de acceso al hombre en la actualidad...................................... 108

IV. 3 La antropovisión en el pensamiento lobatiano......................................... 119

IV. 3. 1 Metantropología como fundamento ................................................ 120

IV. 3. 2 El 'homo viator' como desarrollo ................................................... 123

IV. 3. 3 El humanismo cristiano como culminación ........................................... 143

CAPÍTULO V DESAFÍOS Y RETOS DE LA UNIVERSIDAD DESDE EL HORIZONTE

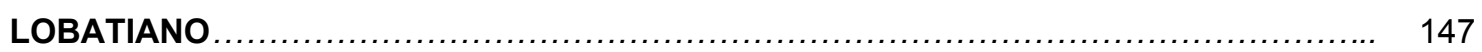

V. 1 La universidad en el pensamiento lobatiano .......................................... 147

V. 2 La Universidad Santo Tomás en Colombia................................................... 151

V. 3. La identidad universitaria tomasina ................................................... 156

V. 4. Campos de intersección entre el pensamiento lobatiano y la USTA - Colombia......... 161

V. 5. Metodología, análisis y resultados ................................................... 162

V. 5.1. Metodología de la teoría fundamentada ............................................ 163

V. 5.2. Instrumento de investigación...................................................... 163

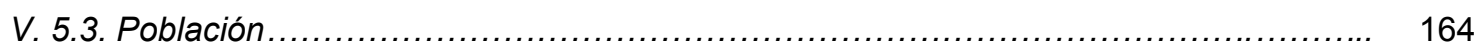

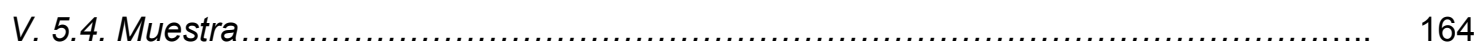

V. 5.5. Resultados de las encuestas. .......................................................... 165

V. 5.6. Interpretación y análisis de los resultados............................................... 188

V. 5.7. FACIENTES HUMANITATIS: Hacia un nuevo humanismo en la educación universitaria para el siglo XXI............................................................ 190

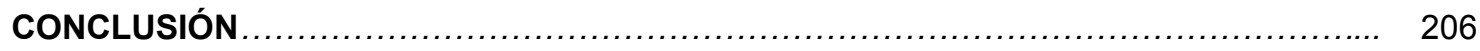

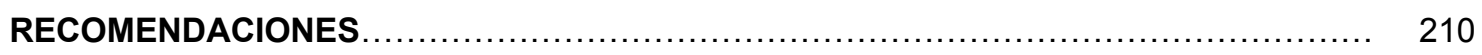

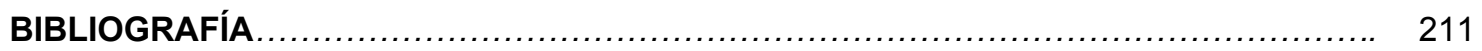

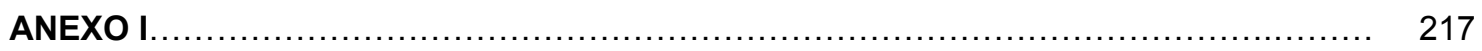

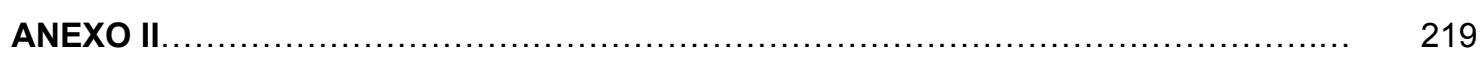




\section{INTRODUCCIÓN}

El presente trabajo de investigación asume por título Antropología y metantropología en Abelardo Lobato. De modo que trata sobre la comprensión del hombre según el pensador dominico y de su propuesta antropológica original que llama metantropología en virtud de su fundamentación metafísica. El subtítulo: nuevo horizonte de comprensión del humanismo cristiano en el contexto de la Universidad Santo Tomas - Colombia, indica la aplicación del pensamiento lobatiano a la compresión de la cultura universitaria y el contexto en el que se lleva cabo la investigación. Así mismo, el espacio es la Universidad porque así lo sugiere la misma obra de Lobato, quien ha pensado la formación o educación del hombre y ha considerado la universidad como lugar de humanización con miras a este objetivo: el hombre llamado a hacerse hombre. De ahí que el horizonte del pensamiento lobatiano sea el humanismo cristiano porque la persona de Cristo es el nuevo modelo de humanidad.

Abelardo Lobato fue un pensador dominico y uno de los mejores conocedores del pensamiento tomista en el presente siglo. De hecho, en sus escritos está siempre el Aquinate como referente teórico. Así mismo, Tomás de Aquino fue el maestro principal de Lobato y su doctrina era la fuente de inspiración para el desarrollo de su propio pensamiento. De modo que por los diversos temas tratados, los abundantes escritos y el desarrollo de ideas que son constantes en su obra se puede hablar con propiedad de doctrina o pensamiento lobatiano. De igual manera, Abelardo fue un pensador siempre atento a los signos de los tiempos, es decir, conocedor de los problemas o interrogantes del hombre en la cultura actual. Sus respuestas constituyen un programa pedagógico o una pedagogía de la respuesta, en la medida que ilumina los problemas pensando siempre en la humanización del hombre.

Para Lobato el hombre es y se hace. El concepto hacerse hombre es una de las ideas principales del humanismo cristiano en el pensamiento lobatiano. De ahí el interés por rescatar el tema de las virtudes morales que ayudan a la realización del hombre. Además, consideró y exaltó los lugares donde se forma al ser humano, que según el pensador eran cuna o útero para la formación y desarrollo de la humanización del hombre.

Ahora bien, entre los principales lugares para formar al hombre y para hacer al hombre en cuanto hombre están la familia, la escuela y la universidad, espacios donde se forja la 
humanidad del hombre. De manera que para el pensador dominico la comprensión del hombre y su formación humana fueron sus principales temas de interés. Asimismo, centró su atención y preocupación por la humanización del hombre, como quedó plasmado en su pensamiento, escritos y en su enseñanza o intervenciones en los diferentes centros de formación institucional.

De ahí nació el interés de Lobato por desarrollar una teoría o comprensión del hombre que ha llamado metantropología -por su fundamentación metafísica-, con el fin de conocer la verdad integral del hombre, y así presentar una antropología integral frente a la atomización antropológica en la cultura actual. En el marco del pensamiento antropológico de Lobato y de la universidad como lugar de humanización del hombre ha surgido la pregunta de investigación planteada: ¿De qué manera la comprensión del hombre desde la metantropología en Abelardo Lobato posibilita un horizonte de conceptualización del humanismo cristiano en el contexto universitario?

Para desarrollar el presente trabajo de investigación a la luz del tema y la pregunta planteados se han propuesto los siguientes objetivos: El general es: Trazar derroteros que permitan la comprensión de la metantropología en Abelardo Lobato para un horizonte de conceptualización del humanismo cristiano en el contexto universitario.

Los objetivos específicos son los siguientes: 1) Señalar los principales estudios e investigaciones que se han realizado sobre la vida y obra de Abelardo Lobato, y de manera sintética los insumos fundamentales del pensamiento de Tomás de Aquino que Lobato articuló a su enseñanza. 2) Describir las teorías principales que orientan el pensamiento contemporáneo frente a las que Abelardo Lobato trata de dar respuesta a través de sus escritos y enseñanza. 3) Identificar los constructos categoriales humanistas en el pensamiento lobatiano. 4) Analizar los constructos epistemológicos en torno a la concepción de metantropología en Abelardo Lobato, que permiten la comprensión del humanismo cristiano. 5) Interpretar la concepción de metantropología como horizonte de conceptualización del humanismo cristiano en Abelardo Lobato en el contexto de la Universidad Santo Tomás de Colombia.

Así mismo, la hipótesis del trabajo de investigación que se plantea es la siguiente: El pensamiento lobatiano está orientado a la constitución y desarrollo de la metantropología; su comprensión permitiría la construcción de un horizonte de conceptualización del 
humanismo cristiano en el contexto propio de la Universidad Santo Tomás de Colombia. El enfoque que se sigue es cualitativo en cuanto se procede implementando la observación, la descripción y la comprensión del fenómeno que se está investigando.

En el mismo sentido, el método empleado es la teoría fundamentada en tanto metodología de investigación para desarrollar una nueva teoría. El método surge y se fundamenta del proceso de recolección, análisis y sistematización de datos. La teoría fundamentada asume como propósito final generar o descubrir una teoría, en este caso entre la metantropología y el contexto de la Universidad Santo Tomás-Colombia, donde se desarrolló la investigación. De ahí que en relación con la metodología se ha utilizado la técnica de la encuesta para la recolección de datos, y como herramienta el cuestionario.

Las categorías a las que se hará alusión y tejerán el desarrollo de la investigación son: metantropología, horizonte, formación, humanismo cristiano, integralidad. A su vez, éstas están tomadas en su concepción lobatiana, teniendo presente los textos y contextos en los que se han planteado por el autor. El entorno en el que se ha realizado la investigación es la Universidad Santo Tomás (USTA) de Colombia. Así mismo, la población o muestra son los estudiantes de los distintos programas que adelantan asignaturas propias del Departamento de Humanidades y Formación Integral de la USTA - Colombia.

Esta investigación está dividida en cinco capítulos:

El primer capítulo se titula Presupuestos fundamentales del pensamiento lobatiano, en el cual se señalarán los principales estudios realizados sobre el pensador dominico Abelardo Lobato. Se dividirá en tres acápites: en el primero se alude a los diferentes estudios abordados en torno a la vida, escritos y pensamientos de Lobato. En el segundo apartado se mencionarán los referentes o principios teóricos del pensamiento lobatiano, es decir, los principales temas de interés que constituyen olvidos radicales de la cultura contemporánea: el olvido del ser, el olvido de Dios, el olvido del alma, el olvido de la verdad y el olvido de la virtud. En el tercer apartado se desglosarán los principales insumos del pensamiento tomista que han iluminado la doctrina y enseñanza de Lobato, a partir de los cuales intentará responder a los principales problemas o interrogantes que se ha planteado el hombre en su contexto contemporáneo.

El segundo capítulo se titula Estado de la cuestión. En él se describirán las principales teorías que han conformado y orientado el pensamiento contemporáneo y a las que 
Abelardo Lobato debe afrontar con su enseñanza y escritos. De modo que se subdividirá en dos acápites: en el primero se subrayará cómo el pensar contemporáneo ha generado una cultura caracterizada como una cultura sin pedagogos. El hombre en su afán de reafirmarse en sí mismo ha proclamado la 'muerte de Dios', pero mediante ella ha devenido la muerte del hombre, que ha quedado sin fundamentos. En el segundo se advertirán las consecuencias o efectos de esta cultura sin pedagogos, entre ellas el mundo frágil, quebradizo, líquido y efímero.

El tercer capítulo se titula Tamizaje bio-bibliográfico de Abelardo Lobato, dentro del cual se identifican los constructos categoriales humanistas del pensador dominico. Además, se perfilará una presentación de su vida y obra. El tema se deslindará en dos partes: en la primera se resaltará la vida de Lobato, caracterizada por su humanismo y tomismo. En efecto, él siempre estuvo en defensa y promoción del humanismo del hombre, a la enseñanza del pensamiento tomista. En el segundo subtema se aludirá a las principales líneas de interés e investigación. De manera que se han parcelado y sistematizado los diferentes escritos temáticamente. Es abundante la bibliografía del pensador dominico y muy diversos los temas que trató.

El cuarto capítulo se titula Metantropología en Abelardo Lobato, tema medular alrededor del cual se analizan los constructos epistemológicos en torno a la concepción de metantropología, núcleo que permite la comprensión del humanismo cristiano. Se subdivide en dos tópicos: en el primero se resaltará la incidencia que ha tenido Tomás de Aquino en el pensamiento de Abelardo Lobato en cuanto a su personalidad y doctrina. El segundo tratará sobre el horizonte conceptual de Abelardo Lobato: el humanismo cristiano sobre la fundamentación de la metantropología y la cristología.

El quinto capítulo se titula Desafíos y retos de la Universidad desde el horizonte lobatiano. En él se subrayará el sentido y la finalidad de la universidad para el pensador dominico. A su vez, éste se subdividirá en dos apartados: el primero versará sobre el significado de la universidad como lugar de formación y educación de la persona, así como sobre el papel fundamental del maestro y del estudiante en el proceso de enseñanza-aprendizaje. En el segundo disertará sobre la facientes humanitatis, la educación en el siglo XXI. A la luz de la metodología de la teoría fundamentada, en la que se comparará y contrastará el pensamiento lobatiano con la cultura universitaria de la Universidad Santo Tomás, se formulará la teoría de la facientes humanitatis como una nueva forma de pensar la universidad y la formación humana: hacer al hombre plenamente hombre. 


\section{CAPÍTULO I}

\section{PRESUPUESTOS FUNDAMENTALES DEL PENSAMIENTO LOBATIANO}

El objetivo del primer capítulo es señalar los principales estudios e investigaciones que se han realizado sobre la vida y obra de Abelardo Lobato, y de manera sintética los principios fundamentales del pensamiento de Tomás de Aquino que Lobato articulaba a su enseñanza. De modo que el abordaje es tripartito: 1. Estado del arte, es decir, los principales estudios que hasta el momento se han realizado sobre la vida y obra de Lobato; 2. Referentes teóricos, es decir aquellos principios teóricos de la doctrina lobatiana; 3. Insumos fundamentales del pensamiento tomista que iluminaron la respuesta de Lobato a los principales problemas y omisiones radicales de la cultura actual.

\section{1 Estado del arte}

Sobre el pensamiento de Abelardo Lobato son muy pocas las investigaciones sistemáticas que se han realizado hasta el momento. No obstante, son varios los estudios que se han hecho sobre su vida y escritos. Entre estos estudios elaborados se pueden mencionar los siguientes en orden de fecha, de aparición y dignos de tener en cuenta por tratarse de uno de los representantes más idóneos del tomismo del presente siglo y a nivel mundial. De modo que entre los principales estudios biográficos y bibliográficos realizados sobre Lobato descuellan:

GUY, Alain. Historia de la filosofía española. Barcelona (España): Anthropos, 1985, 402 p.

DÍAZ DÍAZ, Gonzalo. Hombres y documentos de la filosofía española. Madrid (España): CSIC, 1991, Vol. IV, pp. 726-732.

CONTAT, Alain. "Bibliografía di P. A. Lobato". En: Sanctus Thomas de Aquino, Doctor hodiernae humanitatis. Miscellanea oferta dalla SITA al suo Directtore Prof. Abelardo Lobato per il suo LXX genetliaco a cura di Daniel Ols, O.P., Pontificia Accademia di S. Tommaso e di Religione Cattolica. Cittá del Vaticano: Librería Editrice Vaticana, 1995, pp. $11-19$

DÍAZ DÍAZ, Gonzalo. "Abelardo Lobato Casado". En: Sanctus Thomas de Aquino, Doctor hodiernae humanitatis. Miscellanea oferta dalla SITA al suo Directtore Prof. Abelardo 
Lobato per il suo LXX genetliaco a cura di Daniel Ols, O.P., Pontificia Accademia di S. Tommaso e di Religione Cattolica. Cittá del Vaticano: Librería Editrice Vaticana, 1995, pp. 20-23.

FORMENT, Eudaldo. "La antropología en Abelardo Lobato". En: Sanctus Thomas de Aquino, Doctor hodiernae humanitatis. Miscellanea oferta dalla SITA al suo Directtore Prof. Abelardo Lobato per il suo LXX genetliaco a cura di Daniel Ols, O.P., Pontificia Accademia di S. Tommaso e di Religione Cattolica. Cittá del Vaticano: Librería Editrice Vaticana, 1995, pp. 182-226.

FORMENT, Eudaldo. "Homenaje de la SITA de Barcelona al P. Abelardo Lobato". Cristiandad (1996), pp. 38-40.

FORMENT, Eudaldo. “El tomismo de Abelardo Lobato”. Espíritu (1996), pp. 209-222.

FORMENT, Eudaldo. Historia de la filosofía tomista en la España contemporánea. Madrid, España: Ediciones Encuentro, 1998, pp. 325-379.

FORMENT, Eudaldo. "La neoescolástica en la segunda mitad del siglo XX". En: GARRIDO, M. El lenguaje filosófico y científico del siglo XX. Madrid (España): Ediciones Cátedra, 2005, pp. 519-527.

MONDIN, J. B. La metafísica de S. Tommaso d Aquino e i suoi interpreti. Bologna, Italia: ESD, 2002, pp. 161-166.

Ahora bien, entre los estudios mencionados hay que acentuar principalmente sobre tres que sintetizan en su conjunto la biografía, los principales temas de interés de Lobato y gran parte de sus escritos. El primer autor es el sacerdote diocesano y filósofo Alain Contat de origen ginebrino (Suiza), asistente en los años 90 de Lobato en el Angelicum (Roma), y quien fue su director de tesis. En su artículo Bibliografía di P. A. LOBATO ha recogido una gran parte los diferentes escritos de Lobato que hasta el momento se habían publicado. Además menciona otros escritos del autor que no han salido a luz pública, fruto de su enseñanza e investigación.

Por su parte, Contat presenta la bibliografía de Abelardo Lobato dividida en los siguientes apartados: A) Libros: en los cuales menciona los que han sido propios o de la autoría de Lobato. Así mismo, menciona aquellos libros que han estado bajo la dirección del autor. B) 
Artículos: divididos en seis grandes apartados y en el siguiente orden: 1. Estudios tomistas. 2. Historia del pensamiento. 3. Metafísica. 4. Antropología. 5. Filosofía política. C) Cursos universitarios: en los cuales se hace alusión a los principales temas de su enseñanza universitaria. D) Recensiones. No obstante, este autor aclara que la bibliografía la ha reducido a lo esencial, es decir, a los escritos de carácter científico, sin mencionar toda la bibliografía. Pero al mismo tiempo es preciso resaltar que es uno de los estudios sistematizados de la bibliografía de Lobato.

El segundo autor es el filósofo, historiador y bibliógrafo español Gonzalo Díaz Díaz. En su escrito Lobato Casado, Abelardo, plasma una presentación sintética de la biografía, el pensamiento y la bibliografía de Lobato, resaltando tres aspectos del pensador:

1) La formación de los estudios iniciales y dominicanos. En este apartado señala los estudios en su pueblo natal y los lugares institucionales de la Orden, así como los maestros dominicos que fueron forjando la formación dominicana e intelectual de Lobato. Además se destaca la actividad docente que ejerció Lobato en diferentes instituciones educativas, pero principalmente en aquellos lugares o centros de formación dominicana por donde pasó.

Así mismo, las diferentes actividades académicas las codifica a partir de congresos relacionados con Tomás de Aquino. 2) Las principales líneas de pensamiento de Lobato, dentro de las que señala fundamentalmente tres: ontológica, en la que penetra en el conocimiento del ente y sus propiedades; antropológica que para Díaz se estructura en tres momentos: los fenómenos humanos, la esencia y las relaciones constitutivas. Aunque para Díaz en la comprensión del hombre en Lobato subyacen dos ideas fundamentales de inspiración tomista: 1. El alma quasi horizon et confinium y la antropología integral; 2. El tomismo, en el que siguen tres direcciones: 1. La comprensión histórica y análisis del contexto; 2. El conocimiento de la obra de Aquinate; 3. El diálogo con el pensar contemporáneo. 3) Finalmente, Díaz recoge y menciona una serie de escritos de Lobato, sobre todo libros y artículos de revista científica pero no mayor a la expuesta por Contat.

El tercer autor es el filósofo español Eudaldo Forment, catedrático de metafísica de la Universidad de Barcelona. Es probablemente uno de los mejores conocedores de la vida y obra de Abelardo Lobato que haya hasta el momento. En su escrito Historia de la filosofía tomista en la España contemporánea, dedica el capítulo IV intitulado Metafísica y Antropología: Abelardo Lobato, al estudio del pensador dominico. A lo largo del capítulo desarrolla de manera sucinta diez temas fundamentales, a saber: 1. La apertura del ente; 
2. Ente y unidad; 3. La verdad y la bondad; 4. La belleza y su trascendencia; 5. Metafísica del hombre; 6. El alma y el cuerpo en la antropología; 7. La individualidad personal; 8. La dignidad antropológica; 9. Filosofía de la libertad; 10. Trascendencia del fundamento humano.

Forment es uno de los filósofos que en sus escritos y exposición sobre la vida y obra de Lobato es el que más logra resumir y sistematizar las principales líneas de su pensamiento. De igual manera en su exposición del pensamiento lobatiano -al tratar cada uno de los temas propuestos- recurre a las fuentes del autor como lo indican las citas y notas marginales. Forment concluye citando del mismo Lobato: El reto del tercer milenio consiste en lograr, contra viento y marea, el desarrollo de la dignidad, en todos los hombres y en todo lo humano. Es un reto que afecta de modo peculiar a los cristianos, a los que profesamos la fe en Jesucristo, el Hombre perfecto, el ejemplar de toda dignidad.

Estos tres escritos se complementan mutuamente y se constituyen una introducción a la vida, escritos y líneas principales del pensamiento de Lobato. De igual manera son importantes para construir el tamizaje bio-bibliográfico del pensador dominico y profundizar sobre su pensamiento.

Hasta el momento existe una investigación sobre el pensamiento de Abelardo Lobato del sacerdote Mario Alanoca Chura: La Dignidad Humana en el pensamiento filosófico de Abelardo Lobato. La investigación fue presentada en la Facultad Eclesiástica de Filosofía de la Universidad de Navarra (2006), como tesis de licenciatura en filosofía, dirigida por el Dr. José Ángel García Cuadrado. El objetivo del autor fue profundizar en la noción de dignidad, resaltando en especial su fundamentación metafísica como base de los derechos humanos fundamentales.

Para lograr su propósito divide la investigación en tres capítulos: el primero está dedicado a El problema de la dignidad en el mundo de hoy. En éste realiza unas consideraciones sobre el concepto 'dignidad' en el siglo XX, seguido de la perspectiva científica, filosófica y teológica. Además realza las manifestaciones de la dignidad humana según Lobato -al decir de Alanoca-, la declaración de los derechos humanos, la libertad religiosa y la promoción de la mujer. En el primer capítulo llega a la conclusión de que el esclarecimiento de la dignidad humana implica una reflexión y un discurso sobre la persona. 
El segundo capítulo -La persona humana: dignidad ontológica-, profundiza sobre el concepto de persona desde la comprensión del hombre en el pensamiento de Lobato. Alanoca desarrolla la idea de Lobato de inspiración tomista: la persona constituida de cuerpo y alma. El cuerpo y el alma son los principios del hombre. En el segundo capítulo llega a la conclusión de que la persona es un ser digno por su propia naturaleza. Es esa su dignidad ontológica. Un regalo de Dios, que no puede perder en ninguna situación, por ningún motivo. La dignidad ontológica es inherente a su ser. Ningún acto puede ser capaz de borrar esta dignidad sustantiva, intrínseca de todo ser humano.

El tercer capítulo -La dignidad moral: una conquista del ser-, desarrolla la idea de Lobato sobre la dignidad como un don pero también una conquista por medio de las virtudes humanas. Así mismo, la dignidad moral es una conquista del ser, de la persona. El lugar de desarrollo y conquista de la dignidad es la persona y sus relaciones interpersonales. El autor concluye el capítulo afirmando que está en las manos del hombre conquistar la dignidad moral o perderla por el mal uso de la libertad.

Las conclusiones generales a las que llega el autor de la investigación son las siguientes: 1) Para Lobato hablar de la dignidad es hablar de la persona humana; 2) La correcta concepción de la persona o del ser del hombre sólo puede darse desde la metafísica o la metantropología; 3) La dignidad humana es connatural al hombre, el gran regalo de su propia naturaleza; 4) El ser humano es una subsistencia, un ser personal. 5) El fundamento último y definitivo de la dignidad humana se encuentra en Dios. 6) La persona está llamada a conquistar la dignidad moral a lo largo de su vida. 7) Sólo siguiendo el camino de la virtud se obtiene un verdadero desarrollo de la persona. 8) La persona humana necesita agruparse con los demás para lograr su perfección, pero también para difundir la que ya posee.

En cuanto a investigaciones que sobre el pensamiento lobatiano se hayan realizado hasta el momento podemos señalar tan sólo una, cuyo tema central ha sido la dignidad de la persona. Sin embargo, conviene subrayar el interés que han tenido muchos autores por resaltar la vida, los escritos y las principales líneas del pensamiento de Abelardo Lobato. Así mismo, el pensamiento lobatiano ha sido reconocido por sus múltiples intervenciones en centros de formación y por sus contantes publicaciones en revistas científicas. 


\section{2 Referentes teóricos}

Los referentes teóricos del pensamiento lobatiano a los que nos remitimos en el desarrollo de la presente investigación están suscitados por la misma obra de Lobato, como respuesta a los interrogantes que le surgieron en la cultura actual. Él fue el pensador que respondió a través de sus escritos a los diferentes problemas, retos y desafíos de la humanidad en el presente de manera crítica, mediante la cual abrió nuevos horizontes de comprensión y vías de solución a cada uno de los problemas planteados. De modo que podría afirmarse que gran parte de la obra escrita de nuestro autor estuvo dirigida a la constitución y desarrollo de la metantropología, como uno de los temas centrales de su pensamiento, y dirigida a superar los cinco olvidos y problemas de la cultura actual que la hacen frágil y vulnerable: el olvido del ser, el olvido de Dios, el olvido del alma, el olvido de la verdad y el olvido del bien. A propósito, en uno de sus últimos escritos evidenció el interés y esfuerzo de su pensamiento:

\footnotetext{
El siglo XX y el segundo milenio concluyen con una pesada carga y en un cierto abismo, que desdora sus notables triunfos. Nuestro mundo tiene menos luz y por ello menos esperanza. Heidegger hablaba de dos fenómenos típicos de nuestra hora, descritos en su lenguaje un tanto enigmático, como huida de los dioses y olvido del ser. No se puede menos de estar de acuerdo con esta descripción de las carencias de nuestra cultura. Hay olvidos radicales en ella, que la hacen frágil, quebradiza, inconsistente. Hay un olvido de Dios, que ha venido como consecuencia del olvido del ser. Ello ha hecho posible otros olvidos que inciden en la marcha de la dignidad. Hay que notar en esta lista otros tres olvidos radicales: el olvido del alma, el olvido de la inteligencia y el olvido de la virtud. Mientras no superemos todos estos olvidos estamos desmemoriados. La memoria integral es esencial a la cultura. Uno se pregunta cómo recuperar todo lo que se ha olvidado. Con tanto olvido este hombre de nuestro entorno no está para afrontar ningún examen. El tribunal más benévolo e indulgente tiene que suspenderlos ${ }^{1}$.
}

Por lo tanto, para Lobato uno de los aspectos que caracteriza la cultura actual es el olvido. Así mismo, éste ha sido radical en cuanto ha afectado los principios fundamentales del humanismo del hombre, de su esencia y existencia. $Y$ esto hace que de algún modo se pueda ubicar el pensamiento de Lobato en un horizonte anamnético en cuanto a la búsqueda y recuperación de lo que la humanidad ha perdido al reiniciarse en una novedad sin fundamentos. No obstante, una respuesta al cómo recuperar lo que se ha olvidado lo hace Lobato desde una tesis de inspiración platónico-tomista:

\footnotetext{
${ }^{1}$ LoвATo, A. Dignidad y aventura humana. Salamanca (España): Edibesa, 1997, p. 14.
} 
Para dar solución al problema del hombre y a los problemas humanos hay que situarlo, al estilo de los neoplatónicos, como anillo de conjunción entre dos horizontes, el de ser y el del hacerse, porque el hombre es y se hace. La esfera del ser lleva a la trascendencia, en la cual el hombre se entiende como la realización de uno de los modos de ser, y como fundado en el Ser, religado a Dios. Por este lado no hay posible antropología sin ontología y sin teología. En el otro extremo del anillo humano está el mundo creado por el hombre como ser libre, un mundo cultural envolvente, admirable, en el cual el hombre está llamado desde dentro y desde fuera a comportarse a lo que es y a lo que debe ser. Lo antropológico está sometido a la primacía de los valores culturales, éticos y religiosos ${ }^{2}$.

En este orden de ideas, aludimos a los lineamientos principales en los que Lobato referencia los cinco olvidos de la cultura actual y que la afectan en detrimento de la humanización del hombre. Así mismo, se recurre a los textos del autor en los que de alguna $u$ otra manera trató sobre estos olvidos y la manera como los afronta, y que se constituyen en los referentes de la presente investigación.

Primer olvido: el olvido del ser. Lobato es un profeta de nuestro tiempo que denuncia los grandes olvidos que empobrecen la cultura actual, al decir del pensador dominico: "Se da una alethofobia en la cultura empobrecida del s. XX, que ha perdido el ser, se ha alejado de los dioses y se ha contentado con lo relativo y provisorio. Es este un fenómeno de la modernidad $^{3}$. Entre las denuncias de Lobato estuvo el del olvido del ser. De modo que una de las ideas centrales y originales de Tomás de Aquino que retomó Lobato para su pensamiento fue la del ser como acto: "La novedad tomista consiste en el salto de una filosofía de la esencia a una comprensión del acto de ser”4.

En su escrito Ser y belleza estudió profundamente el ser y sus propiedades. Con respecto al tema de la belleza y sus propiedades afirmó lo siguiente:

Se trata de la belleza. Es de todo punto necesario decir dónde está y qué es, cuáles son las notas que la constituyen y la hacen diferente de todo lo demás, cuáles son las causas que la hacen posible. Para que esto sea firme y seguro, hay que recurrir al ser ${ }^{5}$.

Así mismo, consideró que es importante el retorno y elaboración de una auténtica filosofía del ser. Es así que el estudio del ser constituyó uno de los fundamentos para el desarrollo de su pensamiento.

\footnotetext{
2 Ibíd., p. 13.

${ }^{3}$ LobAto, A. "Tomás de Aquino, modelo de quienes buscan la verdad". Ius Publicum. (2002), núm. 8, p. 13.

4 LobATo, A. "La persona en Santo Tomás de Aquino". Ius Públicum. (2001), núm. 6, p. 22.

${ }^{5}$ LobAto, A. Ser y belleza. Barcelona: Herder, p. 12.
} 
Es posible que la superación de la situación se encuentre en un retorno a la elaboración de auténtica filosofía, la filosofía del ser, y auténtica teología, la teología que habla de Dios y todo lo ve a la luz de la fe. Y es posible que ambas sabidurías, la humana y la divina, sólo se desarrollen correctamente cuando se establece la relación de armonía, y el filósofo prepare los caminos al teólogo, y éste utiliza la sabiduría humana al servicio de la inteligencia ${ }^{6}$.

De igual manera, la filosofía del ser le sirvió para su comprensión del hombre en tanto salvaguarda de las diferencias en las que se realiza la humanidad. Como lo indica Lobato: "La teoría tomista del ser, como acto ha hecho posible esta concepción del hombre que salva las diferencias de la especie, de los individuos y de las personas singulares en las cuales se realiza la humanidad"7.

Segundo olvido: el olvido de Dios. Otro de las grandes omisiones que afecta radicalmente la comprensión del hombre es la de Dios. Como lo señala el mismo Lobato: "Hay en torno al hambre de absoluto, urgencia de encontrar un fundamento, necesidad de superar los grandes olvidos, el del ser, el de los valores y sobre todo el de Dios"8. Una de las ideas constante de Lobato es que el hombre solo se comprende de manera integral de cara a Dios. De manera que el hombre no se puede entender desde si mismo porque se convierte en un laberinto sin salida. Para Lobato:

El pensar contemporáneo se ocupa ante todo del hombre, se ocupa casi en exclusiva de él. Dejó a Dios por estimarlo inalcanzable en el mejor de los casos, dejó al mundo por estar sometido al poder y al dominio de las ciencias, y se quedó con el hombre, dejando el mismo hombre en el vacío, desligado de lo divino, y desenraizado del mundo ${ }^{9}$.

De modo que Dios queda desligado de toda realidad humana, al punto de una ausencia teológica en la vida del hombre y de la historia de la humanidad. Así mismo, el hombre quedó en una especie de vacío existencial, pero al mismo tiempo tranquilo e incluso hasta el extremo de la negación de Dios con el anuncio de su muerte.

\footnotetext{
${ }^{6}$ Lobato, A. "El uso y abuso de la filosofía en teología en el análisis de las primeras obras de Santo Tomás". En: S. Tommaso Teologo. Ricerche in occasiones dei due centenari accademici a cura di Antonio Piolanti. Città del Vaticano: Libreria Editrice Vaticana, 1995, p. 59.

${ }^{7}$ LobATO, A. "La antropología de Santo Tomás de Aquino y las antropologías en nuestro tiempo". En: LobAto, A. (Dir.) y otros. El pensamiento de Santo Tomás de Aquino para el hombre de hoy. Vol. I, El hombre en cuerpo y alma. Valencia: EDICEP, 1995, p. 45.

${ }^{8}$ Lobato, A. "El hombre y el misterio de Dios". En: Lobato, A. (Dir.)., y otros. El pensamiento de Santo Tomás de Aquino para el hombre de hoy. Vol. II, El hombre y el misterio de Dios. Valencia: EDICEP, 2007,

p. 19.
LoBAto, A. "Catequesis y pensamiento contemporáneo". Communio, Vol. 12 (1979), p. 58.
} 
Uno de los fenómenos más preocupantes de nuestra situación cultural es la ausencia, el olvido, el eclipse de Dios. En esta coyuntura al hombre de nuestro tiempo parece preocuparle más el silencio de Dios que el Dios del silencio, porque de hecho se instala tranquilo en la vaciedad del agnosticismo, o se confiesa impotente para una escala a la trascendencia, no tiene reparos de unirse al coro de los que gritan a lo loco que "Dios ha muerto", pero no puede tolerar que Dios siga callado ante el dolor. Sobre todo el dolor que califica de inocente e inútil. En una cierta fuga de lo divino, topa con sus huellas. El tema de Dios es inevitable, como si se tratara de una espina clavada en la carne ${ }^{10}$.

Según Lobato -y en seguimiento del Aquinate- el hombre es un proyecto de Dios y se realiza de manera plena en la persona de Cristo. Como lo indicó:

El hombre es para Tomás un proyecto de Dios, que se realiza plenamente en Cristo, y de modos infinitos en los seres humanos, que tanto crecen en humanidad en cuanto se conforman con Cristo. La humanidad de Cristo es punto de partida para el pensador cristiano ${ }^{11}$.

Otro de los textos de Lobato en que siguió esta misma idea del hombre como proyecto de Dios realizable en la persona de Jesucristo es el siguiente:

El proyecto hombre, que es ante todo un proyecto de Dios, se parte del dato del misterio de Jesucristo. En la vida íntima de Dios y en la obra ad extra de la Trinidad, Jesucristo ocupa un puesto singular. Está al principio, como origen de todo lo que procede en Dios, y de lo que procede de Dios. Todos los ríos de las perfecciones que brotan de Dios Creador vienen a unirse en Él, quien en verdad es el centro y el vértice de la creación. Y por él, por su obra, todo vuelve a sus principios para conseguir la plenitud para la cual fue creado. El proyecto hombre se realiza en Jesucristo. $Y$ en él está incluida toda la Creación. La fe y la teología del misterio de Jesucristo están en el centro del proyecto hombre, que tiene su origen y su término en Dios ${ }^{12}$.

Tercer olvido: el olvido del alma. En la comprensión del hombre la categoría fundamental en Lobato es la de antropología integral:

El ser humano tiene muchos interrogantes abiertos, en espera de respuesta y, entre ellos, los más inquietantes son los que se refieren a la propia comprensión. Todavía el hombre se pierde en su propio laberinto. Llevado por un cierto instinto connatural, desde la presencia que tiene de sí mismo, responde con certeza sobre su existencia, pero se siente incapaz de abarcar su ser y su

\footnotetext{
${ }^{10}$ LobAto, A. "El silencio de Dios y el Dios del silencio". Communio, Vol. 32 (1999), núm. 2., p. 273.

${ }^{11}$ LoBAto, A. "El hombre a la luz del misterio de Cristo". En: LOBATO, A. (Dir)., y otros. El pensamiento de Santo Tomás de Aquino para el hombre de hoy. Vol. II, El hombre, Jesucristo y la Iglesia. Valencia: EDICEP, 2007, p. 31.

12 LoBATO, A. "Jesucristo y el proyecto hombre" En: LoBATO, A. (ED), Actas del IV CONGRESO INTERNACIONAL DE LA S.I.T.A. Tomo I, Ponencias. Córdoba (España): Publicaciones Obra Social y Cultura Cajasur, 199, p. 300.
} 
destino. El hombre es enigma para sí mismo, un gran abismo, decía Agustín. El salmo 8 es una ayuda para plantear el problema ante Dios: ¿Señor, dueño nuestro, qué es el hombre? ${ }^{13}$.

Para Lobato el hombre era, como en Tomás de Aquino, un compuesto de alma y cuerpo. Más aún, él fue un defensor de la verdad integral del hombre y rechazó todo dualismo o reduccionismo antropológico. Al decir lobatiano:

Como ser finito, el hombre es un ser compuesto. Para comprenderlo es preciso partir de la unidad que acompaña siempre al ser, distinguir los diversos componentes por vía de análisis, para volver a recomponer la unidad en la vía de la síntesis. El resultado es una antropología integral ${ }^{14}$.

En otro de sus escritos sobre la unidad del hombre en el pensamiento tomista, comentó lo siguiente:

Tomás ha hecho del hombre una verdadera síntesis de los opuestos, un horizonte en el cual confluyen cuerpos y espíritus. El hombre es un ser de este mundo y el cuerpo es de su esencia. El hombre es al mismo tiempo en condición carnal, sometido al espacio y al tiempo. Situado en el confín del tiempo y de la eternidad, el misterio del hombre participa del misterio de las cosas porque todo confluye en su unidad superadora de lo múltiple, y refleja mejor que ninguna otra creatura algo del misterio de Dios ${ }^{15}$.

Para la comprensión de la verdad integral del hombre y evitar todo riesgos de reduccionismo y atomización antropológica, el pensador dominico consideró que es necesario su fundamentación y la integración de las diferentes formas de comprensión del hombre desde la metantropología. Así mismo, Lobato acuñó el concepto metantropología como nuevo horizonte de comprensión del hombre y propuesta antropológica que la denomina así por su fundamentación metafísica. Como él lo indicó:

La superación de la situación actual requiere poder realizar la fundamentación de la antropología en la metantropología, y la integración de aquella en las diversas antropologías. El discurso va del contexto a la comprensión, de ésta a la integración, y por ella a la fundamentación. El discurso filosófico no puede eludir el ser arqueológico, fundamental. Como el hombre se trasciende a sí mismo en cualquier situación, la antropología culmina en metantropología o metafísica. Sólo en esa trascendencia se hace posible la integración de las diversas perspectivas de las

\footnotetext{
${ }^{13}$ LoBATO, A. "La mujer y el varón cara a cara. El problema de la diferencia". Angelicum, Vol. 72, (1995), p. 541.

${ }^{14}$ LobAto, A. "La antropología de Santo Tomás de Aquino y las antropologías en nuestro tiempo". Op. Cit., p. 37.

${ }^{15}$ Lobato, A. "El humanismo de la ley según Santo Tomás. Verbo (1977), núm. 151-152, p. 81.
} 
antropologías actuales, en lo que presentan de valioso y permanente, y la radicación de lo humano en el ser por encima y más allá del aparecer ${ }^{16}$.

Cuarto olvido: el olvido de la inteligencia. Para Lobato el olvido de esta facultad humana es el olvido de la verdad, de la cual se nutre la vida del hombre. De manera que para Lobato: "La vida intelectual no se nutre de ideas, sino de verdades. Por ello necesita adecuarse a la realidad de las cosas, que existen en singular"17. Al mismo tiempo se ha convertido en una de las crisis de la cultura actual, para quien la verdad le resulta irrelevante. Para Lobato el hombre ha nacido para la verdad que se fundamenta en el ser:

Lo decisivo es el ser, desde el cual se llega a Dios y a la verdad. La crisis de la verdad afecta las raíces de la cultura de Occidente. El eclipse de Dios en nuestro tiempo es al mismo tiempo eclipse del ser y de la verdad. La superación de esta situación decadente de la cultura actual requiere una nueva actitud: frente a la huida de Dios se exige una puesta en marcha hacia el encuentro con Dios, una recuperación de la Trascendencia, una respuesta a la vocación intelectual de todo hombre a la verdad ${ }^{18}$.

Además, para Lobato el hombre por naturaleza desea y busca la verdad. La pasión por la verdad anida en el interior del hombre. De manera que:

El hombre nace con capacidad para la verdad, y por naturaleza tiende hacia ella. Pero sólo la encuentra cuando la busca con pasión. Tomás ha hecho de la búsqueda el principal ejercicio de su existencia. Una vez que la ha encontrado ha sentido el deber de comunicarla. En esta doble tarea de búsqueda y de comunicación ha pasado su existencia. Por ello, es modelo y es maestro de cuantos buscan la verdad, y logran encontrarla parcialmente en los entes, y en totalidad como horizonte siempre abierto, en su fundamento absoluto que es Dios, y en su realización integral, en Jesucristo. El ejemplo luminoso de Tomás -buscador de la verdad en su época- resalta con más fuerza sobre el fondo oscuro de nuestra situación cultural ${ }^{19}$.

Quinto olvido: el olvido de la virtud. Otro de los olvidos radicales en la cultura actual y que afecta la vida del hombre y la relación con los demás es el de la virtud, que hace bueno al sujeto y sus actos. Abelardo llama a esta situación crisis ética que afecta al hombre y sus fundamentos antropológicos. Fue así que Lobato acentuó la recuperación moral de la

\footnotetext{
16 LoBATo A. "Antropología y metantropología: Los caminos actuales de acceso al hombre". En: Antropologia e Cristologia ieri e oggi. Atti del CONVEGNO DI STUDIO DELLA SITA. Roma: Pontificia Universitá S. Tommaso D'Aquino, 1987, p. 7.

${ }_{17}^{17}$ LoBATO, A. Dignidad y aventura humana. Op. Cit., p. 108.

${ }^{18}$ LoBATO, A. "La paideia exigida por la verdad". En: Robert Christian, O.P. (Eds.). La formazione integrale domenicana. Bologna: 1996, p. 275.

${ }^{19}$ LoBATO, A. "Tomás de Aquino, modelo de quienes buscan la verdad". Ius Publicum (2002), núm. 8, p. 11.
} 
virtud, para el desarrollo de todas las facultades humanas que ayudan al hombre a hacerse hombre:

El drama se convierte en tragedia porque toda crisis ética es crisis del hombre. No es lícito dejar al hombre en el vacío, a la intemperie con peligro de perder su propia humanidad sólo por alienarlo en conquista de su mundo exterior. Una crisis ética de la humanidad es una crisis de fundamentos. El hombre de hoy se hunde y grita a su modo por la salvación. Y no hay salvación mientras no recupere su condición de ser moral, y con una ética de valores absolutos por los cuales se vive y se muere ${ }^{20}$.

Según Lobato el hacer humano debe estar orientado a su desarrollo integral, a la humanización del hombre. De igual manera los adelantos científicos y técnicos deben estar al servicio del auténtico progreso humano. Pues el resultado del hacer humano puede ser bueno o contraproducente para la humanidad cuando el hombre se convierte en medio y no en fin. Como lo indica el autor:

La regla definitiva de la producción humana ha de ser lo humano en cuanto tal, que es fin y no medio, el hombre como tal, al cual se ordenan los diversos productos. El ideal será siempre aspirar a que el hombre conquiste su genuina perfección, tanto individual como socialmente. Y por cuanto la perfección del hombre reside en el desarrollo pleno de su persona, como espiritual y como libre, en la adquisición del ser trascendente y de sus propiedades, el hacer tiene que tender en sus productos a facilitar esa perfección, a hacerla posible y real. Así, el hacer en su término recobra el humanismo pleno que tenía en su principio. Viene de la persona y vuelve a ella. Su tragedia puede consistir en no volver contra ella, como ocurre con excesiva frecuencia, y por ello adquiere un nuevo dramatismo el humano hacer ${ }^{21}$.

Para Lobato es central la formación moral del hombre en las virtudes morales, ya que hacen bueno al sujeto y los actos que realiza. Además cumplen a cabalidad la noción de virtud a tal punto que se convierten en el hombre en una segunda naturaleza en su forma de ser y actuar. Como lo señala Lobato:

Ya hemos topado con las virtudes dianoéticas y factivas, las de la mente y las de la técnica. Es necesario indagar también las virtudes de la praxis. En verdad son éstas las que realizan de modo pleno la noción de virtud. La virtud es un hábito operativo bueno. Es como una segunda naturaleza que capacita para realizar los actos, con modalidades de rapidez, facilidad y con deleite. Las virtudes no sólo hacen bien los actos que se piden a las potencias sino que hacen

\footnotetext{
${ }^{20}$ LoBATo, A. "Ética y futuro del hombre". Verbo (1994), núms. 321-322, p. 52.

${ }^{21}$ LoBATO, A. "El problema del hacer humano". Salmanticensis. Vol. 13 (1996), fasc. 2, p. 323.
} 
bueno al sujeto que las ejercita. Esta segunda nota no se cumple del todo en las otras virtudes, las intelectuales o factivas ${ }^{22}$.

\section{3 Insumos fundamentales del pensamiento tomista que inciden en la respuesta lobatiana a los olvidos de la cultura actual}

Los insumos fundamentales del pensamiento tomista que inciden en el pensamiento lobatiano o que van a iluminar su doctrina son importantes para comprender la manera como este dominico los articula a su enseñanza, y así poder responder a los olvidos radicales del hombre en la cultura actual. Así mismo Lobato ha desarrollo desde el Aquinate una pedagogía de la respuesta a los olvidos que han afectado en su esencia y existencia la humanidad del hombre. Tomás de Aquino como maestro no le aportó respuestas elaboradas a Lobato sino que le enseñó a responder por sí mismo. A continuación se traen a colación de manera sintética aquellos textos tomistas que fueron iluminadores en la enseñanza de Abelardo Lobato.

a) El ser como acto. La concepción del ser como acto es uno de los principios fundamentales del pensamiento tomista y un insumo importante para el pensamiento lobatiano. Es posible que a partir del estudio y la comprensión del ser como acto haya desarrollado y creado Lobato el concepto de metantropología y la consiguiente comprensión metantropológica del hombre. Para el Aquinate el ente es lo primero que el entendimiento capta, por ser el objeto formal propio del mismo, o el aspecto bajo el cual alcanza lo que conoce. Entre los textos de Santo Tomás en los que hizo alusión al ser como acto podemos citar los siguientes:

1. Todo ser es perfecto en cuanto está en acto:

El ente es lo primero que el entendimiento concibe como lo más conocido y en lo que resuelve todas las concepciones $(\ldots)^{23}$.

En este caso, el ente no puede entenderse sin lo verdadero, porque el ente no puede entenderse sin que concuerde o se adecúe al entendimiento ${ }^{24}$.

El mismo ser es lo más perfecto de todas las cosas, pues se compara a todas las cosas como acto, ya que nada tiene actualidad sino en cuanto que es. De ahí que el mismo ser sea actualidad

\footnotetext{
22 LoBATO, A. Dignidad y aventura humana. Op. Cit., p. 163.

${ }^{23}$ TOMÁs DE AQUINO. Q. D., sobre la verdad., a. 1.

${ }^{24}$ Ibíd., ad. 3.
} 
de todas las cosas y también de todas las formas. De hecho, no se compara a las otras cosas como el recipiente a lo recibido, sino en especial como lo recibido al recipiente. Pues cuando digo ser del hombre, o del caballo, o de otra cosa, este mismo ser es considerado como formal y recibido, no como algo al que le compete $\operatorname{ser}^{25}$.

(...) el ser es lo más íntimo de una cosa, lo que más la penetra, ya que es lo formal de todo lo que hay en la realidad $(\ldots)^{26}$.

Todo ser es perfecto en cuanto está en acto. Imperfecto, por el contrario, en cuanto está en potencia con privación del acto $^{27}$.

b) Sobre el conocimiento de Dios y su presencia en el mundo. Tomás de Aquino es un teólogo por vocación y en su comprensión teológica de la realidad concibió que todo cuanto existe ha salido de Dios y vuelve a Él. De manera que Dios está presente en todas las cosas por ser su causa y su fin último de todo lo que existe. Así mismo, el hombre puede llegar a tener un conocimiento de Dios en las cosas creadas o por sus efectos; sin embargo, se le ha dado a conocer de manera plena en la persona de su Hijo Jesucristo. De esta comprensión teológica en el Aquinate se sirvió Lobato para hablar de la presencia de Dios en la historia de la humanidad. Además es constante Lobato en afirmar que Dios no es enemigo del hombre sino que promociona su plena realización. Entre las afirmaciones del Aquinate sobre Dios podemos subrayar las siguientes:

\section{El conocimiento de Dios por sus efectos}

Cuando se demuestra la causa por el efecto, es necesario usar el efecto como definición de la causa para probar la existencia de la causa. Esto es así sobre todo por lo que respecta a Dios. Porque para probar que algo existe, es necesario tomar como base lo que significa el nombre, no lo que es; ya que la pregunta qué es presupone otra: si existe. Los nombres dados a Dios se fundamentan en los efectos, como probaremos más adelante (q.13 a.1). De ahí que, demostrando por el efecto la existencia de Dios, podamos tomar como base lo que significa este nombre Dios $^{28}$.

2. El nombre de Dios: El que es.

Tres razones explican por qué El que es es en grado sumo el nombre propio de Dios. 1) Por su significado, pues no significa alguna forma, sino el mismo ser. 2) Por su universalidad, pues todos

\footnotetext{
${ }^{25}$ TomÁs de Aquino. Suma de Teología, I, q. 4 a. 1 ad. 3.

${ }^{26}$ Ibíd., q. 8. a. 1

27 TOMÁS DE AQUino. Summa contra Gentiles, lib. 1 cap. 28.

${ }^{28}$ TomÁs de Aquino. Suma de Teología, I, q. 2, a. 3.
} 
los otros nombres o son menos comunes, o, si le son equivalentes, sin embargo le añaden algún concepto por el que, en cierto modo, lo informan y determinan. 3) Por el contenido de su significado, pues significa existir en presente. $Y$ eso en grado sumo propiamente se dice de Dios, cuyo existir no conoce el pasado ni el futuro, como dice Agustín en el V De $\operatorname{Trin}^{29}$.

\section{Dios está en todas partes:}

Como quiera que el lugar es una cosa determinada, estar en algún lugar puede entenderse de dos maneras: o como están las demás cosas, es decir, como algo está del modo que sea en otras cosas, así los accidentes del lugar están en un lugar; o como algo que está según el modo propio de un lugar, así los seres colocados están en un lugar. En cierta manera, de ambos modos está Dios presente en todo lugar, que es lo mismo que estar en todas partes. Del primer modo, porque así como está en todas las cosas dándoles ser, virtud y acción, así también está en todo lugar dándole virtud locativa. También porque las cosas colocadas están en un lugar llenándolo; y Dios lo llena todo. Pero no como cuerpo; pues se dice que el cuerpo llena un lugar en cuanto que no lo puede ocupar otro cuerpo. En cambio, el que Dios esté en algún lugar, no impide que otros estén allí. Precisamente, Él llena todos los lugares, porque da ser a todas las cosas colocadas que son las que llenan todos los lugares ${ }^{30}$.

\section{Dios se da a conocer de manera plena en Jesucristo:}

Dios, al encarnarse, no rebaja en nada su majestad; y por lo mismo no disminuye el motivo de nuestra reverencia hacia Él. Más bien aumenta por la ampliación de nuestro conocimiento. Al acercarse a nosotros por medio de la Encarnación, nos proporcionó un mayor conocimiento de Él ${ }^{31}$.

c) Antropología tomista. Para Tomás de Aquino el hombre es una unidad substancial de cuerpo y alma. Además para el Aquinate todo hombre es persona, es decir, un ser digno que conduce su humanidad a plenitud en la medida que desarrolla todas sus facultades naturales. Además, el hombre es un ser relacional, es decir, un animal social y político porque no es un ser autosuficiente.

La familia es la primera forma de vida social. Así mismo, el hombre y mujer o los padres son los primeros responsables de la educación y promotores de la persona. Esta concepción tomista del hombre dará origen a la antropología integral en Abelardo Lobato. De igual manera de la comprensión tomista del hombre se pueden mencionar los textos e ideas centrales:

\footnotetext{
${ }^{29}$ Ibíd., I, q. 11, a. 13

${ }^{30}$ Ibíd., I, q. 8, a. 2.

31 Ibíd., III, q. , a. 2 ad. 3.
} 


\section{Proporción y armonía del cuerpo humano:}

Pero el fin próximo del cuerpo humano es el alma racional y sus operaciones, pues la materia se ordena a la forma, y el instrumento a la acción del agente. Por lo tanto, decimos que Dios hizo el cuerpo humano en la mejor disposición para tal forma y operaciones. Si parece que hay algún defecto, hay que tener presente que se trata de una consecuencia necesaria de la misma materia que se precisa para que se dé la debida proporción entre el cuerpo y el alma y sus operaciones del alma ${ }^{32}$.

\section{El alma humana, forma del cuerpo:}

Si el alma no se uniera al cuerpo como forma, se seguirá que el cuerpo y sus partes no tendrían el ser específico por el alma, lo cual se ve claramente ser falso: porque cuando se va el alma ya no se dice ojo, o carne y hueso, a no ser de modo equívoco, como el ojo pintado o el ojo de piedra. Por lo cual es evidente que el alma es forma y esencia del ser de este cuerpo, es decir, aquello por lo cual este cuerpo tiene su razón de especie ${ }^{33}$.

\section{El cuerpo y la persona humana:}

Persona significa lo que en toda naturaleza es perfectísimo, es decir, lo que subsiste en la naturaleza racional. ${ }^{34}$

Pues, porque en las comedias y tragedias se representaba a personajes famosos, se impuso el nombre de 'persona' para indicar a alguien con dignidad. Por eso en las iglesias empezó la costumbre de llamar 'personas' a los que tienen alguna dignidad. Por lo cual algunos definen la persona diciendo que es la hipóstasis distinguida por la propiedad relativa a la dignidad. Como quiera que subsistir en la naturaleza racional es de la máxima dignidad, todo individuo de naturaleza racional es llamado persona $(\ldots)^{35}$.

\section{Hombre y mujer: la sociedad doméstica.}

Se refiere a la primera, que es la comunidad entre varón y mujer. Como es necesario dividir a la ciudad en sus partes mínimas, es preciso sostener que la primera combinación de las personas que no puede ser la una sin la otra es la de varón y mujer. Pues esa combinación se da en razón de la generación por la cual se procrean varones y mujeres. Se desprende de esto que no puede permanecer o ser el uno sin la otra ${ }^{36}$.

\footnotetext{
32 Ibíd., I, q. 91, a. 3.

33 TOMÁs DE Aquino. Q. D., de las Creaturas Espirituales, a. 1.

${ }^{34}$ Tomás de Aquino. Suma de Teología, q. 29 a. 3.

${ }^{35}$ Ibíd., a. 4.

${ }^{36}$ Tomás de Aquino. Comentario a la Política de Aristóteles, lib. 1, lec. 1.
} 
El hijo, en realidad, es naturalmente algo del padre. En primer lugar, porque, en un primer momento, mientras está en el seno de la madre, no se distingue corporalmente de sus padres. Después, una vez que ha salido del útero materno, antes del uso de razón, está bajo el cuidado de sus padres, como contenido en un útero espiritual. Porque, mientras no tiene uso de razón, el niño no difiere del animal irracional ${ }^{37}$.

\section{La formación humana:}

En efecto, la naturaleza no pretende únicamente la generación de la prole, sino también su progreso y desarrollo hasta conseguir su estado perfecto en cuanto hombre, o sea, el estado de virtud" $^{38}$.

Conducción y promoción al estado perfecto del hombre en cuanto hombre, que es el estado de virtud $^{39}$.

d) Búsqueda y comunicación de la verdad. La verdad es uno de los temas centrales en la vida y pensamiento de santo Tomás. En sus diversos escritos manifestó su interés por buscarla y comunicarla a los demás. Uno de los aspectos importantes de la verdad es su contemplación, búsqueda apasionada y comunicación. Para Lobato la verdad es una búsqueda constante de todo hombre porque ha nacido para ella, además es fundamental para la humanización del hombre. El hombre y la humanidad no pueden vivir sin la verdad. Así mismo, la verdad conquistada ha de ser trasmitida o enseñanza de una generación a otra porque es una búsqueda comunitaria. En Tomás de Aquino podemos señalar los siguientes textos en torno a la verdad:

\section{La verdad procede de Dios:}

Toda verdad, quienquiera que la diga, procede del Espíritu Santo en cuanto infunde en nosotros la luz natural y nos mueve a entender y expresar la verdad ${ }^{40}$.

\section{El bien del entendimiento humano es la verdad:}

El fin último del universo es, pues, el bien del entendimiento, que es la verdad ${ }^{41}$.

(...) la verdad es la adecuación de la cosa y del entendimiento ${ }^{42}$.

El hombre por naturaleza desea conocer la verdad ${ }^{43}$

\footnotetext{
${ }^{37}$ TOMÁS DE AQUINO. Suma de Teología, II-II, q. 10 a. 12

${ }^{38}$ TOMÁs DE AQUINO. Suplemento. q. 41 a. 1.

${ }^{39}$ TomÁs de Aquino. Comentario a las Sentencias de Pedro Lombardo, lib. 4 d. 26 q. 1 a. 1.

${ }^{40}$ Ibíd., I-II, q. 109, a. 1 ad. 1.

${ }^{41}$ TOMÁS DE AqUINO. Summa contra Gentiles, lib. 1 cap. 1.

42 TOMÁs DE AQUINO. Q, D., sobre la verdad, a. 1.
} 


\section{La contemplación y comunicación de la verdad:}

Por tanto, la vida contemplativa tiene un solo acto como término final de su perfección, es decir, la contemplación de la verdad, y muchos actos mediante los cuales llega a este acto final. De ellos, unos se refieren al conocimiento de los principios, desde los cuales se eleva a la contemplación de la verdad; otros pertenecen a la aplicación de esos principios a la verdad, cuyo conocimiento se busca, y el último acto completivo es la misma contemplación de la verdad ${ }^{44}$.

Esto se ve con claridad meridiana en el hecho de que es propio del hombre el hablar, por medio del cual una persona puede comunicar a otra totalmente sus ideas. En cambio, los otros animales expresan mutuamente sus pasiones por gestos comunes, como el perro su idea por el ladrido y otros animales diversas pasiones de distintos modos. Luego el hombre es más comunicativo para otro hombre que cualquier otro animal gregario que pueda verse, como la grulla, la hormiga y la abeja $^{45}$.

Por consiguiente, hay que decir que las obras de la vida activa son de doble clase. Unas se derivan de la plenitud de la contemplación, como son la enseñanza y la predicación (...) Y esto es más apreciado que la simple contemplación, puesto que, así como es más perfecto iluminar que lucir, así es más perfecto el comunicar a otros lo contemplado que contemplar exclusivamente ${ }^{46}$.

5. Para la búsqueda de la verdad, es preciso tener conocimiento de los diferentes argumentos:

Y así, es de suma importancia ver los argumentos de las opiniones contrarias, para tener conocimiento de la verdad ${ }^{47}$.

e) La vida del hombre basada en las virtudes morales: Tomás de Aquino ha sido un gran maestro en la formación de la persona. Para la formación de la persona se requiere el desarrollo de las facultades que por naturaleza posee. $Y$ la manera de poner en acto las potencias del hombre es por medio de las virtudes. Entre las virtudes intelectuales, morales y productivas el Aquinate dio una gran importancia para la educación del hombre a las virtudes humanas, es decir, aquellas que hacen bueno al sujeto y sus actos. Las virtudes están orientadas al crecimiento humano, a ser dueños de sus actos mediante la razón y la voluntad. De la vida moral del hombre Tomás de Aquino señala lo siguiente:

\footnotetext{
${ }^{43}$ TOMÁS DE AQUINO. Q. D., sobre el mal, q. 9 a. 1.

44 TomÁs de Aquino. Suma de Teología, II-II, q. 180, a. 3.

${ }^{45}$ TomÁs de Aquino. La Monarquía. Al Rey de Chipre, lib. 1, cap. 1.

${ }^{46}$ TOMÁs dE AQUINO. Suma de Teología, II-II, q. 188, a. 6.

47 TomÁs de Aquino. Comentario al libro de Aristóteles sobre el cielo y el mundo, lib. 1, lec. 22.
} 


\section{El hombre es dueño de sus actos:}

De entre las acciones que el hombre realiza, sólo pueden considerarse propiamente humanas aquellas que son propias del hombre en cuanto que es hombre. El hombre se diferencia de las criaturas irracionales en que es dueño de sus actos. Por eso, sólo aquellas acciones de las que el hombre es dueño pueden llamarse propiamente humanas. El hombre es dueño de sus actos mediante la razón y la voluntad; así, se define el libre albedrío como facultad de la voluntad y de la razón ${ }^{48}$.

\section{Las virtudes morales son las que hacen bueno al sujeto y sus actos:}

Se dice que el hombre es bueno absolutamente por las virtudes morales y no por las virtudes intelectuales $(\ldots)^{49}$.

Y como la virtud es la que hace bueno al que la tiene y que su obrar sea bueno, a tales hábitos se les da absolutamente el nombre de virtudes, porque hacen que su obrar sea bueno en acto, y hacen que sea absolutamente bueno el que los tiene ${ }^{50}$.

Pues el hombre es el mejor de los animales si en él se perfecciona la virtud hacia la cual posee natural inclinación. Empero, si vive sin ley ni justicia, es el peor entre todos los animales ${ }^{51}$.

\section{Las virtudes cardinales:}

Así, pues, podemos considerar las cuatro antedichas virtudes de dos modos. Uno, en cuanto a las razones formales comunes, y en este sentido se llaman principales, como generales a todas las virtudes, de manera que toda virtud que obre el bien en la consideración de la razón se llame prudencia; y que toda virtud que obra el bien debido y recto se llame justicia; y que toda virtud que cohíbe y reprime las pasiones se llame templanza; y que toda virtud que fortalece el alma contra cualquier pasión se llame fortaleza (...) Pero también pueden considerarse de otro modo, en cuanto que estas virtudes reciben su denominación de aquello que es principal en cada materia, y así son virtudes especiales, contradivididas de las demás. Se llaman, sin embargo, principales respecto de las otras por la principalidad de la materia. Así se llama prudencia a la que es preceptiva; se llama justicia a la que versa sobre las acciones debidas entre iguales; se llama templanza a la que reprime la concupiscencia de los placeres del tacto; y se llama fortaleza a la que causa firmeza ante los peligros de muerte.

De manera que estos principios fundamentales del pensamiento tomista son los principales insumos para el pensamiento lobatiano. Desde aquí Lobato elabora las diferentes

\footnotetext{
${ }^{48}$ TomÁs de Aquino. Suma de Teología, I-II, q. 1, a. 2.

${ }^{49}$ Ibíd., 63, a. 3.

50 Ibíd., q. 56, a. 3.

${ }^{51}$ TomÁs de Aquino. Comentario a la Política de Aristóteles, lib. 1, lec. 1.
} 
respuestas a los olvidos radicales del hombre en nuestra cultura actual. De manera que Tomás de Aquino es el maestro que va a orientar la enseñanza de Lobato, al abordar cada uno de los cuestionamientos planteados. 


\section{CAPÍTULO II ESTADO DE LA CUESTIÓN}

El objetivo del segundo capítulo es describir las teorías principales que orientan el pensamiento contemporáneo frente a las que Abelardo Lobato trata de dar respuesta a través de sus escritos y enseñanza. En la medida en que se conocen los principios teóricos de la cultura contemporánea se pueden conocer mejor sus proyectos, sus logros y fracasos. Además se conocerá el modo como los asumió el pensador dominico y la manera como fueron abordados en sus escritos. Para el desarrollo del presente capítulo se ha dividido en dos apartados: 1. La cultura contemporánea: una cultura sin pedagogos; 2. Las desventuras de una cultura sin pedagogos.

\section{1. La cultura contemporánea: una cultura sin pedagogos}

Los pedagogos han desempeñado una actividad fundamental en el proceso de humanización del hombre y de su historia en todas las culturas y en todos los tiempos. Así mismo, se han caracterizado porque entre sus actos está acompañar, guiar, promover, educar a quienes han tenido bajo su cuidado y responsabilidad. Los principales pedagogos han sido los padres, los maestros, quienes gobiernan una sociedad y Dios. De manera que existen una pedagogía humana y una pedagogía divina que han estado presentes en la historia de la humanidad.

Sin embargo, la cultura contemporánea se ha caracterizado porque es una cultura sin pedagogos y $\sin$ referentes. En ella se considera que el hombre no necesita de un acompañamiento o de un proceso de crecimiento y madurez humana. Una de las críticas constantes que precisamente formula el pensador Abelardo Lobato a la cultura contemporánea es la de una cultura sin Dios, sin padres y maestros. Al mismo tiempo, pareciera que nos hemos olvidado de ellos o se cree no son necesarios ni referentes para la humanidad. Una de las causas de esta situación cultural hay que buscarla en el fenómeno de la llustración. De hecho, a la pregunta ¿qué es la ilustración? el filósofo alemán Kant respondió:

La llustración significa el abandono por parte del hombre de una minoría de edad cuyo responsable es él mismo. Ésta significa la incapacidad para servirse de su entendimiento sin verse guiado por algún otro. Uno mismo es el culpable de dicha minoría de edad cuando su causa no reside en la falta de entendimiento, sino en la falta de resolución y valor para servirse del suyo 
propio sin la guía del de algún otro. Sapere aude! ¡Ten valor para servirte de tu propio entendimiento! Tal es el lema de la llustración $n^{52}$.

Aunque muy seductora la propuesta de la razón ilustrada para el hombre, ésta no dejó de tener sus consecuencias para la historia de la humanidad. Desde entonces el hombre se soltó de las manos de Dios, de los padres y de los maestros para reafirmarse sobre sí mismo, sin la guía de los pedagogos que han acompañado a la humanización del hombre. Así mismo, se desarrolló un humanismo radicalmente ateo que negaba explícitamente la existencia de Dios como condición necesaria para la dignificación del hombre. De igual manera era un proyecto que apuntaba hacia la emancipación del hombre de la tutela de Dios.

Por otra parte, el olvido de los pedagogos de la humanidad se ha convertido en el denominador común de la crisis que aqueja a la cultura contemporánea. No obstante, se ha venido recuperando en el pensamiento actual la memoria como una nueva categoría en el pensamiento filosófico y en la reflexión teológica que busca concientizar sobre las causas de las grandes crisis del hombre de hoy.

De manera que el mundo contemporáneo ha crecido huérfano de sus principales pedagogos y se ha autoalimentado de ideas que han provocado la 'muerte de Dios' y con ella, por ende, la muerte del hombre. Entre las ideas o tesis principales en las que se ha reafirmado el hombre en la contemporaneidad se pueden mencionar de manera principal las siguientes:

a) La proclamación de la muerte de Dios. El pensador alemán Friedrich Nietzsche es uno de los principales exponentes que proclamó la muerte de Dios y uno de los padres del ateísmo contemporáneo. Más aún, plantea que para ser hombre superado, tenemos que asesinar a Dios. La muerte de Dios inaugura una época de nihilismo y de superación de todo lo humano.

La 'muerte de Dios' fue tratada con toda su radicalidad en su escrito Así habló Zaratustra. En efecto, Zaratustra representa en su discurso y predicación al anticristo. Pues, según la fe cristiana Jesucristo al bajar de la montaña había proclamado las Bienaventuranzas como centro de su predicación del Reino de Dios presente en el mundo. Por el contrario, Zaratustra al bajar de la montaña proclamó a la humanidad que Dios había muerto.

${ }^{52}$ KANT, InMmANUEL. Contestación a la pregunta: ¿Qué es la ilustración? Madrid: Gredos, 2010, p. 3. 
Cuando Zaratustra descendió de la montaña y se encontró con un anciano eremita que se había retirado del mundo para amar sólo a Dios, después de una conversación, el profeta comentó para sí: “¿Será posible? ¡Este santo varón aislado en su bosque no se ha enterado todavía de que dios ha muerto!"53 Con la muerte de Dios el ser humano recuperó su libertad y su creatividad, y se tornó autosuficiente.

Nietzsche describió el camino hacia la plena libertad humana a través de diversas imágenes. La primera parte de Así habló Zaraustra se abrió con las tres trasformaciones del espíritu: del espíritu en camello, del camello en león y del león en niño. El primero se caracteriza por el sometimiento a la ley moral, el segundo por la liberación de los preceptos morales y de la voluntad divina, y el tercero se caracteriza por la libertad. El 'superhombre' es la alternativa al vacío dejado por la muerte cultural de Dios. De modo que el superhombre es la superación del hombre y la culminación de todas las cualidades proyectadas sobre el hombre.

b) Antropocentrismo: la teología es antropología. Otra de las ideas que nutre el pensamiento de la cultura contemporánea es la exaltación del hombre como centro de todo. Efectivamente, para el pensador Ludwig Feuerbach la religión surgió como conciencia del infinito; es decir, la conciencia del infinito y la conciencia de sí son inseparables. De manera que la idea central de la antropología trascendental de Feuerbach es: "Todo ser se basta a sí mismo. Todo ser es, más bien, en y por sí mismo infinito, tiene su Dios, su esencia más alta en sí mismo" ${ }^{24}$.

Más aún, para Feuerbach Dios es una creación del ser humano. En otras palabras, Dios no es otra cosa que proyección del ser humano. De esta manera Dios no sería el fundamento de lo humano, sino que lo humano es el fundamento de toda referencia a Dios. Es así que Dios dejó de ser el fundamento de lo que existe. Sin duda que este autor llevó hasta sus últimas consecuencias la más radical reducción de la teología a la antropología, al afirmar: “(...) el verdadero sentido de la teología es la antropología, que no hay diferencia entre los predicados del ser divino y los predicados del ser humano" ${ }^{\prime 55}$. En consecuencia, no es Dios el que ha creado el hombre, sino que es el hombre el que ha creado a Dios.

\footnotetext{
${ }^{53}$ NiETZCHE, FRIEDRICH. Asi habló Zaratustra. Madrid: Edimat Libros, S.A., 2004, p. 38.

${ }_{55}^{54}$ FEUERBACH, LUDWIG. La esencia del cristianismo. Salamanca: Ediciones Sígueme, 1975, p. 56.

${ }^{55}$ lbíd., p. 42.
} 
c) Ateísmo humanista. Otra de las ideas centrales de las que se ha alimentado el mundo contemporáneo es sobre un programa humanista para la construcción de la historia humana y del hombre. Así mismo, se trata de un humanismo caracterizado porque es ateísta y se fundamenta solamente en el hombre. No obstante, para promover este tipo de humanismo se deben abolir sus principales oponentes: Dios y la religión. Entre sus principales mentores y considerados padres del 'humanismo' contemporáneo están Sigmund Freud y Karl Marx. Junto con Nietzsche constituyen la tríada de los 'filósofos de la Sospecha'. Lo que han pretendido estos pensadores es devolverle al ser humano el poder que el hombre había proyectado en una Trascendencia divina para encontrarse consigo mismo y autoafirmarse como un ser libre y liberado.

Ahora bien, el principal descubrimiento de Freud ha sido el mundo del inconsciente. El hombre, lejos de ser un ser racional, se revela como un complejo de fuerzas, de instintos reprimidos. Para Freud la religión es una ilusión humana, fruto del deseo y la carencia. De manera que la religión -principalmente el cristianismo- es un estadio infantil de la humanidad, por lo que crea la necesidad de un 'Dios padre' que nos consuele de las inclemencias de la vida.

De esta manera Freud hizo descubrir que en el concepto de Dios recuperamos la imagen del 'padre' que, inconscientemente, necesitamos para sentirnos seguros. En este orden de ideas, para superar el infantilismo religioso y pasar a la adultez humana es importante la orfandad que renuncia a la dependencia de los padres y maestros. El 'complejo de Edipo' sería la última razón del comportamiento religioso del hombre, del culto al padre y de los sacrificios exteriores. Al decir de Freud:

Creo, en efecto, que gran parte de aquella concepción mitológica del mundo que perdura aún en la entraña de las religiones más modernas no es otra cosa que psicología proyectada en el mundo exterior ${ }^{56}$.

Asimismo, la vinculación de la religión con el complejo paterno es otra de las tesis centrales de la psicología freudiana de la religión. El psicoanálisis descubre la relación íntima entre el complejo del padre y la creencia en Dios. Ésta muestra que la raíz de la necesidad religiosa se encuentra en el complejo paterno-materno. La religiosidad va asociada biológicamente a la necesidad de protección que tiene el niño.

\footnotetext{
${ }^{56}$ FreUd, Sigmund. Psicopatología de la vida cotidiana. En: Obras Completas. Vol. I. Traducción directa del alemán por Luis López-Ballesteros y de Torres. Madrid: Editorial Biblioteca Nueva, 1968, p. 486.
} 
El psicoanálisis nos ha descubierto una íntima conexión entre el complejo del padre y la creencia en Dios, y nos ha mostrado que el Dios personal no es, psicológicamente, sino una superación del padre, revelándonos innumerables casos de sujetos jóvenes que pierden la fe religiosa en cuanto cae por tierra para ellos la autoridad paterna. En el complejo paterno-materno reconocemos, pues, la raíz de la necesidad religiosa ${ }^{57}$.

Por su parte, para Karl Marx los hombres alienan su ser proyectándolo en un Dios imaginario, sólo cuando la existencia real en la sociedad de clases prohíbe el desarrollo y la realización de la humanidad. Esto se debe al fenómeno religioso, que se constituye en un obstáculo más que en un punto de apoyo para la emancipación humana. De manera que Marx denunció que Dios y la religión son el narcótico del pueblo, el opio dirá. Entonces la manifestación de la injusticia social sólo cambiará revolucionariamente las estructuras económicas y sociales, y por consiguiente, la religión desaparecerá por completo del horizonte humano. De manera que para Marx:

La miseria religiosa es a un tiempo expresión de la miseria real y protesta contra la miseria real. La religión es la queja de la criatura en pena, el sentimiento de un mundo sin corazón y el espíritu de un estado de cosas embrutecido. Es el opio del pueblo ${ }^{58}$.

En efecto, no es la religión la que hace al ser humano ni es Dios quien lo crea, sino reiterativamente- es el hombre quien hace la religión y quien crea a Dios. Al decir de Marx: "El fundamento de la crítica religiosa es: el hombre hace la religión, la religión no hace al hombre" ${ }^{25}$. Por lo tanto, el hombre no alienado sería aquél que se realiza transformando la naturaleza con el fin de satisfacer sus necesidades. El hombre es un ser que trasforma el mundo a través de la praxis porque transforma la Naturaleza, las relaciones sociales y a sí mismo. El ser humano es, mientras el Ser supremo para el ser humano:

Ser radical es tomar la cosa de raíz. Y para el hombre la raíz es el hombre mismo. La prueba evidente del radicalismo de la teoría alemana, o sea de su energía práctica, es que parte de la decidida superación positiva de la religión. La crítica de la religión desemboca en la doctrina de que el hombre es el ser supremo para el hombre y, por lo tanto, en el imperativo categórico de acabar con toda las situaciones que hacen del hombre un ser envilecido, esclavizado, abandonado, despreciable ${ }^{60}$.

\footnotetext{
${ }^{57}$ FREUd, SIGMUND. Un recuerdo infantil de Leonardo da Vinci. En: Obras Completas. Vol. II, Op. cit. p. 486.

${ }^{58}$ MARX, KARL. El fundamento de la crítica. Madrid: Gredos, 2012, p. 12.

${ }^{59}$ Ibíd., p. 11.

60 Ibíd., p. 15.
} 
A todas luces, la libertad es otra de las ideas o conceptos que ha alimentado el espíritu moderno. Éste ha identificado su ser hombre con la libertad. Más aún su lema será: yo soy libertad. El primer filósofo moderno de la libertad es Johann Gottlieb Fichte, quien hará de la libertad el modo originario de filosofar, y proclamará que ha logrado el primer sistema de libertad. De modo que Fichte ha exaltado la libertad hasta atribuirle un poder creativo de los valores y de los fines. La moral de Fichte es absolutamente autónoma, como ética de la acción pura. Para él la acción de la libertad tiene el sentido y el fin de la libertad misma:

Pero lo que yo llamo mi yo, mi persona, no es la fuerza natural que forma al hombre, sino sólo una de sus manifestaciones; y de esta manifestación es de lo que yo tengo conciencia en cuanto soy yo, pero no de aquella fuerza de la cual sólo llego forzado por la necesidad de explicarme a mí mismo. Pero esta manifestación, según su actuación real, es algo, indudablemente, que procede de una fuerza originaria y autónoma, y debe representárseme como tal en la conciencia $^{61}$.

De manera que todas las tesis o teorías que comenzaron alimentando la vida del hombre en el mundo contemporáneo han conducido a la 'muerte' y al olvido de Dios. Se ha creído que para el hombre autoafirmarse no tiene otro fundamento que no sea él mismo. Al mismo tiempo, todas las corrientes de pensamiento contemporáneo develan una imagen negativa de Dios, como el que trunca todo proyecto de realización de la humanidad. No obstante, con la 'muerte de Dios' se ha producido la misma muerte del hombre, quien ha quedado sin fundamentos sobre los cuales edificar un proyecto humanista que ayude al hombre a hacerse hombre. Al decir de Lobato:

La autonomía del hombre relega a Dios, la afirmación del hombre es tentación para la negación de Dios. Puesto que nuestro mundo es un mundo fabricado por el hombre, fruto de la ciencia y de la técnica, ha dado origen a un humanismo radical. El fenómeno del ateísmo puede ser consecuencia directa de esta situación. Porque en realidad el ateísmo presenta muchas caras, tiene muy diversas manifestaciones: unos sólo prescinden de Dios en su vida, otros le quieren excluir de lo social, otros lo quieren sustituir por el hombre ${ }^{62}$.

\section{2. Las desventuras de una cultura sin pedagogos}

Los logros y adelantos del hombre han sido cada vez más sorprendentes en los últimos tiempos, sobre todo a nivel científico y tecnológico. Sin embargo, no hay certeza de qué tanto humanamente se han logrado. Además, si los adelantos científicos y técnicos han

\footnotetext{
${ }^{61}$ FICHTE, JOHANn GotTLIEB. El destino del hombre. Madrid: Gredos, 2013, p. 566.

62 LobATO, A. "Secularización y ateísmo". En: Communio. Vol. 1 (1968), Fasc. 1, p. 456.
} 
estado en verdad al servicio de la misma humanización del hombre o en su contra. Pues una cultura sin pedagogos tiene el riego de sus desventuras.

En la cultura moderna el hombre por sí mismo no ha logrado satisfacer todas sus necesidades de ningún orden o dimensión, es decir, corporales, físicas, personales y comunitarias. De manera que nos encontramos con una sociedad insatisfecha, que ha pasado de una cultura de la producción a una cultura del consumismo, pero que no logrado satisfacer ninguna necesidad fundamental humana. La crítica de esta situación actual ha surgido desde su interior: el hombre y la sociedad actual se caracterizan por el miedo, la desconfianza, la inseguridad, el vacío, la liquidez, lo efímero, el riesgo.

A decir verdad, uno de los estados emocionales que se ha apoderado del hombre en la cultura actual es la angustia existencial. Ésta ha generado, entre otras cosas, a nivel personal y comunitario la pérdida de confianza y con ella el sentido mismo de la vida social y política del hombre. Para el médico psiquiatra Vicente Madoz Jáuregui, unos de los principales miedos del hombre moderno es la angustia. Para él: "No deja de resultar curioso que, en esta época actual, en la que todos nos sentimos poseedores de múltiples conocimientos y dueños de un mundo dominado por la razón, esta especie de sinrazón abunde dentro de nuestra comunidad"63. Así las cosas, para el autor: "Se define la angustia como la sensación de miedo sin objeto, es decir, un miedo sin motivo aparente"64. Son angustias neuróticas y enfermizas que afectan la vida personal y social, desde la toma de decisiones hasta el encuentro con el otro.

Para el sociólogo alemán Ulrich Beck, vivimos en la sociedad del riesgo mundial. Y llama 'riesgo mundial' a una serie de acontecimientos destructivos que amenazan la humanidad a nivel global, entre ellas, la guerra, la crisis financiera, el cambio climático, las epidemias. Puede ser que algunas de ellas ya han sucedido, pero subyace la posibilidad de que surjan con más fuerza, lo cual moldea o cambia la vida social, política, religiosa y económica. Como resultado el miedo se ha instalado radicalmente en la vida del hombre contemporáneo. Para Beck:

La categoría del riesgo se refiere por lo tanto a la realidad discutible de unas posibilidades que no es mera especulación, pero tampoco una catástrofe efectivamente acaecida. En el momento en

\footnotetext{
63 JÁUREgUI MAdOZ, VICENTE. 10 palabras clave sobre los miedos del hombre moderno. Pamplona (España): Verbo Divino, 1997, p. 11.

Ibíd., p. 12.
} 
que los riesgos se convierten en realidad - explota una central nuclear o se produce un atentado terrorista- se convierten en catástrofes. Los riesgos son siempre acontecimientos futuros que es posible que se presenten, que nos amenazan y, puesto que esta amenaza permanente determina nuestras expectativas, invaden nuestras mentes y guían nuestros actos, resultando así una fuerza política transformadora ${ }^{65}$.

A juzgar por tantas zozobras, nos encontramos ante políticas de seguridad nacional, de murallas, de fronteras bien definidas. Además, asistimos a una sociedad obsesionada más por la seguridad, que hace que la libertad y la igualdad pasen a un segundo plano. Se intercambia la libertad por la 'seguridad nacional'. Desafortunadamente, se restringen cada vez más los espacios públicos para la vida social y la amistad política:

Formulado de manera algo provocativa: lo que destruye las instituciones occidentales de la libertad y la democracia no es el acto terrorista, sino la escenificación global del mismo, así como las subsiguientes anticipaciones, acciones y reacciones políticas. La restricción de las libertades, sensibles en muchos terrenos -desde el incremento de las cámaras de vigilancia hasta el control de la inmigración- no es simplemente consecuencia de las catástrofes efectivas como, por ejemplo, actos terroristas. Es producto de dichas experiencias y de su anticipación globalizada, esto es, del intento de impedir que tales acontecimientos se produzcan en el futuro en cualquier lugar del mundo ${ }^{66}$.

Así mismo, todos estos acontecimientos que atomizan la vida personal y social del hombre crean nuevos sistemas de gobierno, que se apoderan de todos los miedos del hombre moderno para ofrecer una aparente libertad y seguridad. La psicopolítica ha sido uno de estos nuevos sistemas de gobierno. Se trata de un sistema de dominación que, en lugar de emplear el poder opresor, utiliza el poder seductor, inteligente, que consigue que los hombres se sometan por sí mismos al entramado de dominación. De este modo, el individuo se cree libre, cuando en realidad es el sistema el que está explotando su libertad.

En lugar de hacer de los hombres sumisos, intenta hacerlos dependientes. El poder inteligente, amable, no opera de frente contra la voluntad de los sujetos sometidos, sino que dirige esa voluntad a su favor. Es más afirmativo que negador, más seductor que opresor. Se esfuerza por generar emociones positivas y en explotarlas. Seduce en lugar de prohibir. No se enfrenta al sujeto, le da facilidades ${ }^{67}$.

\footnotetext{
${ }^{65}$ BECK, ULRICH. La sociedad del riesgo mundial: En busca de la seguridad perdida. Barcelona: Paidós, 2008 , p. 27.

${ }^{66}$ Ibíd., 28.

${ }^{67}$ Han, ByUng-Chul. Psicopolítica: Neoliberalismo y nuevas formas de poder. Barcelona: Herder, 2015, p. 29.
} 
Así, los cambios constantes e inesperados que se producen en la sociedad contemporánea han producido inestabilidad en la vida personal y en las relaciones interpersonales. Este fenómeno histórico fue descrito por el sociólogo polaco, Zygmunt Bauman, como mundo líquido. La 'liquidez' es una metáfora que utiliza el sociólogo para aplicarla al actual momento histórico de la humanidad.

Los elementos líquidos -a diferencia de los sólidos que son estables y firmes-, son aquellos frágiles, inestables que pierden la forma de manera constante. De ahí que la vida personal y las relaciones interpersonales se caracterizan por su inestabilidad, lo cual hace imposible tomar decisiones a largo plazo, hablar de proyectos y de compromisos. El hombre debe seguir el ritmo de los rápidos cambios que se van produciendo. Como lo señala Bauman:

En resumidas cuentas, la vida líquida es una vida precaria y vivida en condiciones de incertidumbre constante. Las más acuciantes y persistentes preocupaciones que perturban esa vida son las que resultan del temor a que nos tomen desprevenidos, a que no podamos seguir el ritmo de unos acontecimientos que se mueven con gran rapidez, a que nos quedemos rezagados, a no percatarnos de las fechas de caducidad, a que tengamos que cargar con bienes que ya no nos resultan deseables, a que pasemos por alto cuándo es necesario que cambiemos de enfoque si no queremos sobrepasar un punto sin retorno ${ }^{68}$.

Las relaciones interpersonales se hacen cada vez más frágiles y vulnerables en la sociedad líquida. Los medios de comunicación virtual han cambiado la manera de relacionarse una persona con otra. Así mismo, la comunicación corporal y escrita. La relación que implican la mirada y la corporeidad es suplida por las conexiones y redes, la comunicación deja de ser verbal y escrita, y se hace más emocional y cargada de imágenes. Además, afecta el compromiso interpersonal, de pareja, de amistad, de vida social y política. En las redes y las conexiones se está exento de responsabilidad u obligaciones.

Las conexiones son 'relaciones virtuales'. A diferencia de las relaciones a la antigua (por no hablar de las 'comprometidas', y menos aún de compromisos a largo plazo), parecen estar hechas a la medida del entorno de la moderna vida líquida, en la que se supone y espera que las 'posibilidades románticas' (y no sólo las 'románticas') fluctúen cada vez con mayor velocidad entre multitudes que no decrecen, desalojándose entre sí con la promesa 'de ser más gratificante y

\footnotetext{
${ }^{68}$ Bauman, Zygmunt. Vida líquida. Barcelona: Paidós, 2015, p. 10
} 
satisfactoria' que las anteriores. A diferencia de las 'verdaderas relaciones', las 'relaciones virtuales' son de fácil acceso y salida ${ }^{69}$.

Entonces, para Abelardo Lobato los medios de comunicación social han ampliado el horizonte de información, pero al mismo tiempo han puesto al hombre en una cultura más de la imagen o de la apariencia que de la verdad y lo auténtico. Además, han creado un clima o atmósfera de ceguera moral donde lo bueno y lo malo están en una misma escala de valores. Pero, a su vez, donde el vicio puede tener más espectadores y seguidores que la virtud. En clave lobatiana:

Vivimos en una cultura de la imagen, de los llamados medios de comunicación social, y con expresión más usada mass media. En realidad son medios ambiguos, como todo instrumento. Depende del uso que se hace de ellos. Amplía el horizonte de la información y hace del hombre un auténtico espectador de los eventos del mundo, de las maravillas del cosmos. Pero al mismo tiempo lo detienen en el estadio estético, donde cuenta más la apariencia que la verdad, tienden a ser alienantes, presentan todos los hechos, buenos y malos, en el mismo plano de valores. El espectador asiste pasivo a cuanto le ofrecen. El mal, el sexo, la violencia tienen más espectadores que la virtud. Hay una carrera alocada hacia lo último, a la moda, a lo que tiene resonancia, al escándalo y a la morbosidad. Los mass media colaboran a crear una atmósfera de ceguera y sordera a los valores auténticos ${ }^{70}$.

De igual manera, la revolución digital o la hipercomunicación han transformado las relaciones sociales y ha creado una nueva desrealidad (Baudrillard) llamada enjambre digital. "El enjambre digital consta de individuos aislados"71. Más aún, se caracteriza porque: "En ella los individuos particulares se funden en una nueva unidad, en la que ya no tienen ningún perfil propio" ${ }^{\prime 2}$. Esta nueva forma de vida social despersonaliza las relaciones humanas y nos aleja a unos de otros bajo la ilusión de que nos acerca.

Así mismo, en la cultura contemporánea la educación del hombre encaminada a un proceso estable y duradero en la construcción y adquisición del conocimiento como de la verdad han cambiado por la opinión, lo provisional, lo temporal e inmediato. En otros tiempos el valor de la verdad en el proceso de enseñanza y aprendizaje garantizaba una educación sólida en comparación con la educación liquida que hoy se ofrece, en la era

\footnotetext{
${ }^{69}$ Bauman, Zygmunt. Amor líquido: Acerca de la fragilidad de los vínculos humanos. México D. F.: Fondo de Cultura Económica, 2005, p. 13.

${ }^{70}$ LOBATO, A. "El sentido moral en situación de peligro en la cultura contemporánea". En: Angelicum, Vol. 72 (1995), p. 55.

${ }_{71}^{71}$ HAN, BYUNG-ChUL. En el enjambre. Barcelona: Herder, 2014, p. 26.

72 Ibíd., p. 27.
} 
light... Vistas así las cosas, la educación humana en otros tiempos -en comparación con la educación en la cultura contemporánea- estribaba en que en aquella: "El conocimiento tenía valor puesto que se esperaba que durara, así como la educación tenía valor en la medida en que ofreciera conocimiento de valor verdadero"73. Además, la memoria humana ha pasado de tener una función importante en la enseñanza como en la adquisición del conocimiento, al plano más relegado.

En efecto, la memoria ha sido un lugar donde se guardan los tesoros de la sabiduría divina y de la ciencia humana para compartirlos por medio de la enseñanza. Pero la memoria en la cultura contemporánea -por su liquidez a causa de los constantes cambios y la rapidez de la información- resulta siendo inútil, a tal punto que estamos más adaptados a borrar todo tipo de información y a reciclar aquello que puede servir para el momento:

En semejante mundo la memoria era un valor positivo, tanto más rico cuanto más lejos en el pasado lograra llegar y cuanto más tiempo se conservara. Hoy una memoria tan sólidamente atrincherada parece, en muchos casos, potencialmente inhabitable, en muchos más engañosa, y en la mayoría, inútil ${ }^{74}$.

Por lo tanto, la educación líquida no se caracteriza por aprender y acumular sino por el distanciamiento, la discontinuidad y el olvido. De manera que la educación no crea identidad o estabilidad en las personas porque el conocimiento de la verdad útil para toda la vida ha sido sustituido por el conocimiento del breve disfrute de las cosas.

El hombre en la cultura actual tiene muchas más oportunidades y posibilidades para realizarse; sin embargo, es un hombre insatisfecho. Paradójicamente, queriendo el hombre autoafirmarse en sí mismo, no ha encontrado consistencia. Además, se ha hastiado y ahogado en el vacío de su imagen y semejanza. De hecho, la imagen que mejor ilustra la situación del hombre presente es la del joven griego Narciso, en cuanto recrea el individualismo egoísta y se ha perdido en sí mismo:

En todas partes encontramos la soledad, el vacío, la dificultad de sentir, de ser transportado fuera de sí; de ahí la huida hacia delante en las experiencias que no hace más que traducir esa búsqueda de una experiencia emocional fuerte. ¿Por qué no puedo yo amar y vibrar? Desolación de Narciso, demasiado bien programado en la absorción de sí mismo para que pueda afectarle el

\footnotetext{
${ }_{74}^{73}$ BAUMAN, ZYGMUNT. Los retos de la educación en la modernidad líquida. Barcelona: Herder, 2008, p. 26.

${ }^{74}$ Ibíd., p. 37.
} 
Otro, para salir de sí mismo; y, sin embargo, insuficientemente programado ya que todavía desea una relación afectiva ${ }^{75}$.

Así mismo, el hombre narcisista ha buscado llenar el vacío existencial que se ha creado a través del consumismo que le ofrece la sociedad de la producción. No obstante, como el consumismo material no lo ha satisfecho, lo ha trasladado a su interior. El resultado ha sido mitigar los deseos de felicidad que anidan en su interior, pero que hasta el momento no ha logrado satisfacer. De manera que en el mundo contemporáneo:

El hiperconsumidor ya no está sólo deseoso de bienestar material: aparece como demandante exponencial de confort psíquico, de armonía interior y plenitud subjetiva y de ello dan fe el florecimiento de las técnicas derivadas del Desarrollo Personal y el éxito de las doctrinas orientales, las nuevas espiritualidades, las guías de la felicidad y la sabiduría. El materialismo de la primera sociedad de consumo ha pasado de moda: actualmente asistimos a la expansión del mercado del alma y su transformación, del equilibrio y la autoestima, mientras proliferan las farmacopeas de la felicidad ${ }^{76}$.

En la actual comprensión del hombre tiene cada más fuerza las neurociencias pseudofilosóficas, que no usan la palabra alma sino 'mente'. Del mismo estilo, el reduccionismo antropológico es evidente cuando se explica la complejidad del hombre desde una perspectiva única y en la mayoría de los casos material. Esta comprensión antropológica se ha convertido en un desafío para la filosofía y la teología, que han comprendido al hombre de manera integral y en todas sus dimensiones, del alma que permite iluminar y hacer razonablemente comprensible la relación del hombre consigo mismo, con los otros y con Dios.

El cambio de lenguaje indica una transformación radical de la perspectiva: en lugar de la filosófico-teológica se está asumiendo paulatinamente la científica. No importa si, junto a la mente, se coloca después la psiché o el ánimo o el alma, para designar el conjunto de la vida afectiva, emotiva, o la conciencia fenoménica y la interacción con el colectivo humano. El hecho es que las neurociencias parecen (a veces aseguran) estar en condiciones de explicar todas las reacciones de la persona humana. De esta manera, plantean un desafío tanto a la filosofía como a la teologías clásicas, cuya tradición, según proponen algunos, se debería considerar ya definitivamente superada ${ }^{77}$.

\footnotetext{
${ }^{75}$ LIPOVETSKY, GILLES. La era del vacío. Barcelona: Anagrama, 2003, p. 78.

${ }^{76}$ LIPOVETSKY, GILLES. La felicidad paradójica. Barcelona: Anagrama, 2007, p. 11.

${ }^{77}$ CANOBbio, Giacomo. Sobre el alma: Más allá de la mente y el cerebro. Salamanca: Sígueme, 2010, p. 19.
} 
El repertorio antropológico reciente es muy amplio. Además de la diversidad de enfoques en la comprensión del hombre, existe muchas veces oposición entre ellas. Lo que se ha buscado ante tal variedad es agruparlas en relación a un tema específico y por sus representantes. De modo que para una mejor comprensión se ha realizado la siguiente clasificación según el tema de interés antropológico, a saber: "relación con la realidad físico-biológica (antropo-biología); relación con el propio yo (antropología psicológica); relación con el ser en general (antropología filosófica); relación con el otro ('tú' humano, 'tú' divino: antropología social y teológica)"78.

Entre los mayores exponentes del primer grupo encontramos a: P. Laín Entralgo, $K$. Lorenz, Juan L. Ruiz de la Peña; en el segundo grupo están: C. G. Jung; en el tercer grupo tenemos: X. Zubiri, G. Vattimo; el cuarto grupo está conformado por: E. Levinas, René Girard, H. U. Von Balthasar, W. Pannenberg. Sin embargo, estudios más recientes señalan 24 propuestas diferentes de antropología ${ }^{79}$. En suma, en el marco de las diferentes propuestas antropológicas actuales, la comprensión lobatiana del hombre desde la metantropología se va a constituir en el fundamento de las diversas antropologías y las va a integrar en una antropología integral: En una cultura sin pedagogos y referentes han sido más las desventuras del hombre que sus logros humanos. La humanidad ha quedado a la deriva, sin fundamentos sólidos al soltarse de las manos de Dios. Así mismo, ningún proyecto humano ha traído algún tipo de salvación para la humanidad. Por el contrario, la misma cultura contemporánea ha tomado conciencia de que vivimos en la sociedad del riesgo mundial, de lo efímero o líquido. Expresado con Lobato:

Todo el pensamiento actual se centra en la consideración del mundo desde esta perspectiva humana. El mundo es la obra del hombre. Por muchos aspectos esta obra resulta sorprendente y maravillosa para el mismo hombre que la produce. El mundo interpretado como obra de Dios era un mundo re-ligado a su principio. Dios estaba presente en el mundo de un modo inmediato. Todo se prestaba a una sacralización del mundo. Pero en un mundo visto desde el hombre, referido inmediatamente a él, la religación sacra desaparece y en su lugar surge la autonomía, la independencia, el afán de liberación de todo vínculo. Dios queda relegado. Su puesto lo ocupa ahora el hombre ${ }^{80}$.

\footnotetext{
${ }^{78}$ De Sahagún LuCAS, JuAn. Nuevas antropologías del siglo XX. Salamanca: Sígueme, 1994, p. 11.

${ }^{79}$ Cf. Selles, Juan Fernando. Propuestas antropológicas del siglo XX. Tomos I-II. Navarra (España): EUNSA, 2007.

${ }^{80}$ LoBATO, A. "Secularización y ateísmo". Op. Cit., p. 457.
} 


\section{CAPÍTULO III}

\section{TAMIZAJE BIO-BIBLIOGRÁFICO DE ABELARDO LOBATO}

El objetivo del primer capítulo es conocer la vida y obra de Abelardo Lobato Casado para resaltar los elementos caracterizantes que armonizaron y unificaron su personalidad como los principios fundamentales de su pensamiento. Para el desarrollo del presente tamizaje bio-bibliográfico el capítulo está dividido en dos partes: 1) Abelardo Lobato: La vida de un humanista y tomista; 2) Las principales líneas de interés e investigación del pensamiento lobatiano.

\section{1 Abelardo: la vida de un humanista y tomista}

De los diferentes elementos que perfilaron la vida y obra de Abelardo Lobato tal vez los que mejor definieron su personalidad son humanismo y tomismo. Éstos se evidenciaron en su autobiografía intitulada: Abelardo, haz memoria. Las obras y los días. De Abelardo debemos comenzar afirmando que fue un hombre que anheló y buscó vivir en plenitud:

A uno le gustaría vivir, pero no a sorbos o de limosna, sino en plenitud, como vaso que se llena y desborda, como fuente que fluye y alimenta los arroyos, como árbol en primavera. La vida que uno desea es la buena vida, tan buena que pueda incluirse en esa lista envidiable de "vidas ejemplares". A uno le basta vivir, anhela la buena vida ${ }^{81}$.

Abelardo Lobato Casado nació el 20 de enero de 1925 en San Pedro de la Viña, Zamora (España). De su nombre nos dirá: "me pusieron un nombre medieval, porque así se llamaba mi padrino. Mi nombre debía ser el del santo del día, Sebastián, el Apolo cristiano" ${ }^{\text {"2 }}$. El día en que él nació moría su abuela Emilia. Así mismo, Abelardo al nacer era una persona de condición corporal frágil, a tal punto que presumían una muerte prematura, como se lo recordaba la señora Rosaura, comadrona de ocasión y quien lo asistió en su nacimiento:

Ay, Abelardo, cuando naciste estabas 'amarillín'. Tu madre y yo pensábamos que ibas a vivir muy poco, y decíamos: 'Angelitos al cielo'. No dábamos nada por tu vida. Te encomendamos a la Virgen, te dimos el agua de socorro y esperamos el milagro ${ }^{83}$.

\footnotetext{
${ }^{81}$ Lobato, A. Abelardo, haz memoria. Las obras y los días. Valencia, España: EDICEP, 2011, p. 48.

82 Ibíd., p. 596.

83 Ibíd., p. 49.
} 
Además de esta experiencia personal de vida -cercana a la muerte, como se lo recordaban-, a Abelardo lo marcó el fallecimiento de cuatro de sus familiares. En efecto, cuando Abelardo tenía cinco años murió su abuelo Santiago de manera repentina. La otra muerte fue la de su hermano Germán, accidentalmente envenenado cuando del lugar donde había llevado un saco de harina, para el alimento de la semana, por descuido había dejado al lado un veneno para roedores que se mezcló con la harina. Además, la muerte de su padrino Abelardo durante la guerra civil y la de su primo y religioso dominico Pedro López, asesinado en el Convento de Almagro.

De este contexto surgió una reflexión de convicciones profundas en torno a la vida. De su experiencia natalicia nos dirá: "Quizá por esa entrada temblorosa al nacer he tenido muy arraigada la convicción de que la vida es un don, pero está colgada de un hilo, y que para llevarla a plenitud es preciso nadar contra corriente" ${ }^{84}$. De la muerte de sus seres queridos afirmó: "Estas muertes cercanas, las únicas que nos acercan a la imposible experiencia de la muerte propia, me dejaron muy viva la lección de que la vida es un don, tesoro frágil, una herencia"85. De ahí que su vida se tornara una búsqueda de la verdad y una respuesta integral a la llamada de Dios. Para Lobato:

La vida es hermosa, pero hay valores por los cuales la vida se puede sacrificar, porque son los que dan valor a la vida misma. Uno de ellos es la verdad, pero el valor más alto es Dios mismo. Mi vida quiere ser una respuesta integral a su llamada ${ }^{86}$.

Los padres de Abelardo fueron Gumersindo Lobato y Agustina Casado. Tuvo cuatro hermanos: Pedro, Celestina, Baltasar y el ya mencionado Germán. Nació y creció en el seno de una familia labradora, como lo recordó Lobato: "Mi abuelo y mi padre eran a un tiempo agricultores, carpinteros y herreros. Eran muy trabajadores, siempre ocupados". De igual manera rememoró que colaboraba en el oficio de segador: "Iba a imitar a los segadores en verano. Yo mismo había ido a segar con la hoz cuando era niño. Mientras veía a los mayores llevar cuatro surcos a la vez, yo iba con uno solo y no los alcanzaba" ${ }^{27}$.

Inició su educación y promoción humana en su pueblo natal, en el Colegio La Virgen del Campo, en donde según Lobato: "Tuve la fortuna de aprender latín, a la luz del candil, en las largas noches de invierno, y de tener como maestro al sacerdote ejemplar Don Ángel

\footnotetext{
${ }^{84} \mathrm{Idem}$.

${ }^{85}$ Ibid., p. 51.

${ }^{86}$ Idem.

${ }^{87}$ Ibíd., p. 118.
} 
Saavedra". ${ }^{88}$ A los 14 años entró al Colegio de Almagro para hacerse dominico. Probablemente su primo de la Orden haya incidido indirectamente en esta decisión. De manera que el 15 de septiembre de 1942, a los 17 años profesó como religioso dominico. De igual modo, fueron siete años de formación religiosa y cultural en los centros de formación dominica de Almagro, Salamanca y Roma, de los que comentó: "Almagro fue la cuna, Salamanca, la ciudad universitaria de España, fue mi 'alma mater'. En Roma donde Cristo se ha hecho romano, tuve mi asiento por largos años en la Universidad Santo Tomás" ${ }^{89}$.

En la facultad de Teología de San Esteban de Salamanca inició su formación teológica, y recibió los títulos de Lector y Licenciado en Sagrada Teología, teniendo por maestros a sus hermanos dominicos Santiago Ramírez, Guillermo Fraile y Venancio Carro. Así mismo, allí recibió la ordenación sacerdotal el 16 de abril de 1949. Por otra parte, su formación filosófica la comenzó en el Angelicum de Roma, donde obtuvo en 1951 la Licenciatura en filosofía y en 1952 el Doctorado en filosofía. Realizó la tesis doctoral sobre Avicena y Tomás de Aquino. De igual manera, allí fue instruido por los dominicos Eugenio Toccafondi, Atanasio de Vos y Reginaldo Garrigou-Lagrange.

De regreso a España continuó con su profunda formación en la Escuela de Estudios Árabes y en la Universidad Complutense de Madrid, donde se licenció en 1956 con una monografía sobre La estética de Nicolai Hartmann, que había preparado durante una estancia en Alemania ${ }^{90}$. Su pasión por el diálogo con la cultura musulmán estriba en conocer la tradición filosófica y las fuentes del Aquinate, como él mismo lo señala: "Tuve una temprana pasión por el diálogo con el mundo musulmán, y me escribía como alumno en la escuela de Estudios Árabes de Granada para conocer mejor la tradición filosófica y las fuentes de Tomás de Aquino"91.

Ahora bien, los centros de formación dominicana de Abelardo fueron los primeros lugares de enseñanza. En 1952 comenzó enseñando Historia, Crítica y Cosmología en el Estudio General de los dominicos de Granada; desde 1960 hasta 1970 fue catedrático de Estética de la Pontificia Universidad de Salamanca, en la que sucedió a J. M. Sánchez de Muniaín

\footnotetext{
${ }^{88}$ Ibíd., p. 493.

${ }^{89}$ Ibíd., p. 52.

90 Cf. Santus Thomas de Aquino Doctor Hodiernae Humanitatis. Miscellanea Offerta Dalla Società Internazionale Tommaso D'Aquino al suo Direttore Prof. Abelardo Lobato, O.P. Per il suo LXX genetliaco a cura di Daniel OLS, O.P. STUDI TOMISTICI, núm. 58. Roma, Italia: Librería Editrice Vaticana, 1995, p. 20.

${ }^{91}$ Lobato, A. Abelardo, haz memoria. Las obras y los días. Op. Cit., 493.
} 
(1909-1981); desde 1963 hasta 1996 catedrático de metafísica en la Facultad de Filosofía de la Pontificia Universidad de Santo Tomás de Roma o Angelicum, y Decano de aquella Facultad desde 1972 -a los 47 años- y reelegido por quinta vez en 1989. De igual modo, enseñó y fue Decano del Instituto Regina Mundi de Roma. Desde 1996 hasta el 2001 fue Rector de la Facultad de Teología de Lugano, Suiza. Y al terminar su periodo aceptó ser profesor de Antropología en la Universidad LUDES. Además, desde el 2001 fue titular de la Cátedra de Santo Tomás en la Universidad San Pablo CEU, de Madrid; así mismo, fue titular de la cátedra de Santo Tomás de Aquino de la Universidad Católica San Antonio fundada en el 2005.

Abelardo -como Tomás de Aquino- fue un maestro, un pedagogo que dedicó gran parte de su vida a la enseñanza y a la formación del hombre. Abelardo describe el ambiente que recreaba cuando tenía que preparar sus lecciones: "Cuando voy a una clase o a una conferencia me gusta crear todo un ambiente cultural, me agrada ver la mesa llena de libros sobre el tema, aunque luego no abra ninguno. La sola vista me conforta y evoca su contenido" ${ }^{92}$. De todas maneras, las diferentes responsabilidades no interrumpieron su docencia. Al mismo tiempo se describió como un dominico y discípulo de Tomás de Aquino de pies a cabeza. Se sintió identificado con los centros de formación que llevaban el nombre de Santo Tomás, de modo particular del Angelicum. De su quehacer docente, carisma dominicano y referente tomista nos narra lo siguiente:

No pude cortar esta actividad ni siquiera en los ocho años que fui provincial de Andalucía. Cada año volaba a Roma, para dar algunas semanas de lecciones y tener un apretado cursillo. Pero las cosas de este mundo tienen su fin. Eso no era nuevo para mí, aunque hay cosas que uno estima como la propia vida, la cual nunca se quiere perder. ¡Dime lo que amas, te digo lo que eres! Pues yo era de pies a cabeza un dominico, discípulo de Tomás de Aquino, y profesor en esta Universidad, que debía ser entre todas las que llevan su nombre, la preferida. Aquí en célebres palabras papales, esculpidas, más que escritas, Tomás habita en su propia casa. Y a mí me gusta habitar donde Tomás de Aquino. A su lado se percibe mejor el esplendor de la verdad. ${ }^{93}$

Además de su constante actividad académica, fray Abelardo Lobato asumió una intensa actividad organizativa, entre ellas y muy destacada fue la organización y realización en 1974 del Congreso Internacional sobre Santo Tomás de Aquino con ocasión del VII centenario de su muerte. Esta actividad tomista encomendada por la Orden fructificó en la

92 Ibíd., p. 170.
93 Ibíd., p. 169. 
fundación de la Sociedad Internacional Tomás de Aquino, conocida por la sigla SITA. A este propósito comenta:

La escala de mi vida me presentaba otros peldaños: en 1972, a los 47 años, era Decano de la Facultad de Filosofía del Angelicum de Roma, que lograba tener inscritos más de 400 alumnos, y la Orden me encomendaba la preparación del Congreso Internacional con motivo del VII Centenario de la muerte de Santo Tomás, que resultó el acontecimiento cultural de mayor resonancia en el ámbito eclesial, y dio origen a la $\operatorname{SITA}^{94}$.

Igualmente, Abelardo fue promotor y director -desde la fundación en 1976-, de la Sociedad Internacional Santo Tomás de Aquino. De hecho, en 1997 fue elegido presidente de la prestigiosa sociedad tomista, en la que organizó cinco congresos internacionales. El primero de los socios fue el entonces Cardenal Karol Wojtyla, posteriormente el Papa Juan Pablo II, quien hizo su petición de afiliación como miembro de la SITA el 1 de febrero de 1978, a los dos años de puesta en marcha, y con quien estrechó Lobato una gran amistad. Sobre la SITA recuerda lo siguiente:

Puede decirse una flor de la primavera tomista, cuyo origen hay que situarlo en el Congreso tomista de 1974, al cumplirse en marzo de ese año los siete siglos de la muerte de Tomás de Aquino en Fossanova. Su nacimiento real tiene lugar en 1976 con ocasión del Congreso de Incontri Culturali, en Génova y Santa María Ligure. Pero su existencia oficial hay que datarla el 27 de mayo de 1978, cuando los 12 socios fundadores firman ante notario en el Convento Santa Sabina de Roma, los Estatutos de la sociedad ${ }^{95}$.

Además, Abelardo Lobato, en 1984, fundó el Instituto Fray Bartolomé de Las Casas en Sevilla, de la que también fue presidente. A su vez, fue fundador y director del Instituto de Santo Tomás en la Universidad de Santo Tomás de Roma. Así mismo, fue cofundador del Consejo Internacional de Universidades Santo Tomás de Aquino, conocida con la sigla ICUSTA, entidad cultural que agrupó las Universidades que llevan el nombre de Santo Tomás y las que se adhieren a sus principios.

Entre las responsabilidades asignadas a Abelardo Lobato cabe resaltar ser delegado de la Santa Sede en el Consejo de Europa para los Derechos Humanos desde 1982; el nombramiento por parte de San Juan Pablo II como Presidente de la Pontificia Academia de Santo Tomás de 1999 hasta el 2005, organizando en el 2003 un Congreso Tomista

\footnotetext{
94 Ibíd., p. 493

95 Ibíd., p. 569
} 
Internacional en Roma; ser elegido cabeza de la Provincia Dominicana de Andalucía en 1977 y reelegido para un segundo periodo en 1981; y ser asistente de la Compañía de Santa Teresa y miembro de la Comisión Internacional de Estudios de la Orden Dominicana.

De los reconocimientos o títulos otorgados podemos mencionar los siguientes: dentro de la Orden de Predicadores el grado de Lector; en 1987 fue nombrado Maestro en Sagrada Teología, título máximo dentro de la comunidad dominicana; el de hombre del año por el Biographical American Institute en 1999; el de ciudadano honorario de la ciudad italiana de Aquino en 2001; y el Doctorado Honoris Causa por la Universidad Católica San Antonio de Murcia en 2006.

En otro orden de ideas, Abelardo profesó una devoción especial y admiración por los santos, hombres y mujeres, por su grandeza de espíritu y humanismo. Entre ellos menciona los siguientes:

Mi Padre Domingo, el que llevo más cerca, mi preferido Santo Tomás, con quien camino, mi protector San Juan Macías, mi admirado paisano San Lucas del Espíritu Santo, fray Luis de Granada, la Madre Teresa Titos, la Madre Pilar Bermúdez, y tantos otros ejemplares de santidad que yo he conocido y admirado ${ }^{96}$.

No obstante, en su devoción dominicana, los santos con los que mantuvo una gran familiaridad y cercanía profunda desde la identidad de carisma, y vida intelectual hasta en lo cotidiano fueron Santo Domingo de Guzmán, Santo Tomás de Aquino y San Juan Macías. Además de admirar la grandeza humana y santidad de vida cristiana, le impactaba la concepción de vida que se construye mientras se camina; de ahí el concepto del hombre caminante, o el hacerse hombre mientras camina, o como le gusta decir: homo viator. Para Lobato: "El dominico, si quiere seguir el camino de Domingo, está invitado a hacerse caminante, un auténtico homo viator, tiene que hacer su camino al andar"97. En la vida de sus hermanos de comunidad y santos, Tomás de Aquino y Juan Macías, Abelardo Lobato experimentó su compañía en el camino de hacerse hombre junto con quienes admiraba su itinerancia:

Yo estaba seguro que Tomás de Aquino, itinerante que recorrió en los caminos medievales unos 15.000 kms., la mayor parte a pie, y sólo pocas veces en la nave por el mare nostrum y por el Ródano, y Juan Macías, que se atrevió a ir en barco de Sevilla a las Indias y desde Cartagena a

96 Ibíd., p. 105.
97 Ibíd., p. 377. 
Lima, caminando contracorriente por el río Magdalena y con no pocos peligros por el camino del Inca $(\ldots)^{98}$.

En efecto, Lobato consideró: "Tomás de Aquino nos enseña que Dios quiere de cada uno de nosotros, que lleguemos a la perfección, tanto humana como cristiana”99. De manera que es un programa de vida el hacerse hombre, en el que además de los propios esfuerzos de cada persona, Dios promueve la naturaleza humana y su divinización. Así mismo, Abelardo se propuso vivir a plenitud el humanismo cristiano, pero al mismo tiempo con Tomás de Aquino enseñarlo para humanizar al hombre: "Siento que debo dar gracias, colocar el amor a mí mismo en su puesto y dar nuevos pasos con Tomás, para promover el humanismo cristiano. Una voz interior me aconseja: Abelardo, agradece, ámate, humaniza ${ }^{100}$.

Ahora bien, en la ardua tarea de hacerse hombre y de humanizarlo, el encuentro con los demás es importante porque ayuda a crecer, a descubrir la propia humanidad y el sentido de la vida. Abelardo disfrutaba de la compañía de sus amigos, a quienes se dirigía llamándoles amigos del alma porque los consideraba como otro yo. Efectivamente, para Lobato: "Uno vuelve con gusto al encuentro de las personas con quienes ha compartido el gozo de vivir y te han ayudado a encontrar un sentido más profundo a tu propia vida" ${ }^{\text {101. }}$. Desde luego, consideraba que los amigos hacen parte en la construcción del camino de la vida: "Caminas y cantas. La vida es camino, itinerancia por el mundo, sendero hacia una meta. No es bueno caminar a solas. Es una delicia hacer el camino en buena compañía"102.

A todas luces, Abelardo fue homo viator en su propia vida como lo fue del humanismo y de Tomás de Aquino. De manera que su vida y doctrina mostró el amor e interés por la humanidad del hombre como por la enseñanza del pensamiento tomista. En los diferentes lugares donde hacía sus intervenciones acostumbraban a presentarlo como dominico, un humanista y tomista. Al decir del mismo Lobato: "Me presentaban como dominico español, delegado del Papa, especialista en derechos humanos y en Tomás de Aquino"103.

\footnotetext{
${ }^{98}$ Ibíd., p. 171.

99 Ibíd., p. 439.

100 Ibid., p. 587.

101 Ibid., p. 185

102 Ibíd., p. 117.

103 Ibíd., p. 245.
} 
Como humanista se interesó por el proyecto del hombre nuevo desde el humanismo cristiano inspirado en Santo Tomás. Así mismo, en la comprensión del hombre entendió la vida humana como ascenso, es decir, crecimiento y desarrollo de todas las dimensiones en las que se hace el hombre. La imagen que utilizó para describir la vida ascendente fue la espiral, en cuanto a su punto de partida, de altura y anchura a medida que avanza y termina en la persona de Cristo, el ejemplar del hombre. De manera que cada vuelta representa progreso y plenitud humana. Como lo señala Lobato: "El eje de la vida es un tanto diverso, y es preciso hacerlo en espiral. En cada vuelta uno se encuentra un poco más alto"104.

De igual manera, en su comprensión humanista del hombre consideró que éste está llamado a crecer, a la grandeza humana a pesar de su finitud. Fue así que en su visión del humanismo se dio cuenta de que el hombre está llamado a elevarse, a ser grande. "La aspiración a lo grande y la realidad de lo pequeño se dan cita en el hombre, en todo hombre, que siente la necesidad de ocultar sus miserias bajo un manto de esplendor" ${ }^{\prime 105}$. La anterior descripción antropológica surgió para Lobato de la misma naturaleza humana, es decir, cuerpo y alma, de lo humano y divino, de cuerpo viviente y de espíritu encarnado, pero como una realidad única, en la que se teje y desenlaza lo humano. Como lo señala el mismo Lobato:

\footnotetext{
El ser humano es un misterio para sí mismo. No es un elemento del mundo, es un microcosmos, donde confluyen todas las dimensiones, de naturaleza y cultura, de tiempo y eternidad, de persona y comunidad. Tiene ser corporal como las piedras, vida como las plantas, sensibilidad como las bestias, inteligencia como los ángeles, es capaz del bien y del mal, del amor y del odio, es capaz de Dios ${ }^{106}$
}

Así mismo, para Lobato es fundamental en el humanismo el vivir bien. La expresión no sólo hace alusión a una calidad de vida humana sino a una vida virtuosa. El hombre logra el desarrollo de todas sus facultades por medio de actos que engendran los hábitos buenos o virtuosos. Como lo manifiesta Abelardo en sus experiencias de viajes:

Es connatural al hombre no sólo amar la vida, cuidar la salud, dado que el bien primero y fundamental es la misma existencia, el gran regalo del cielo, sino también la calidad de vida, el

\footnotetext{
104 Ibíd., p. 302.

105 Ibíd., p. 380.

106 Ibíd., p. 611.
} 
vivir bien. Esto se experimenta en los viajes. El homo viator siente la atracción de conocer, descubrir, gustar de recorrer el mundo, lleno de maravillas ${ }^{107}$.

Como tomista, conoció la doctrina de Santo Tomás y la asumió como fundamento para su pensamiento. Además encontró en la doctrina del Aquinate los elementos sólidos para la promoción del hombre desde el humanismo cristiano: "Tomás es un sembrador de humanismo cristiano. Su doctrina es clave para la construcción del nuevo milenio con rostro humano y cristiano" ${ }^{\prime 108}$.

Para Lobato el Aquinate sigue siendo con su doctrina un pensador actual para la formación del hombre en su integridad. De ahí que la enseñanza del dominico español trasluce una fuerte impronta tomista. La enseñanza de la doctrina tomista en Abelardo Lobato no está orientada sólo al conocimiento del Aquinate sino a la educación o formación de la persona, a forjar hombres y mujeres desde lo humano. De manera que para Lobato:

Tomás de Aquino debe ejercer su rol de Doctor Humanitatis, tanto en la extensión, llegando a todos, cuanto en la intensidad, forjando las nuevas generaciones en el pleno desarrollo de la humanidad integral de cada hombre, ser personal siempre único y distinto ${ }^{109}$.

De igual modo, para Lobato todo hombre y cada generación es deudor de lo que se ha construido sobre la verdad del hombre. El filósofo cristiano referencia diferentes fuentes de las que bebe para continuar en la construcción de la verdad, que ha quedado plasmada en la historia de la humanidad y en su memoria colectiva. Para Lobato: "La memoria no es sólo la potencia o facultad del individuo humano, sino de la humanidad como un todo que progresa o se degrada en el tiempo" ${ }^{\prime 10}$. Más aún, Tomás se ha convertido para el hombre de hoy en una fuente para la promoción del humanismo integral. Así éste supo recoger de lo cultivado por sus predecesores, analógicamente Abelardo reconoce que no podemos olvidar la herencia tomista: "Hoy estamos llamados a asumir las dos tareas inseparables, la de recoger su herencia, y la de imitar su capacidad creativa en el futuro, de modo especial en los tres campos: antropología, ontología y teología, que son las bases de todo desarrollo"111.

\footnotetext{
${ }^{107}$ Ibíd., p. 379

108 Ibíd., p. 319.

${ }^{109}$ Ibíd., p. 221

110 Ibid., p. 615.

${ }^{111}$ Ibíd., p. 311.
} 
En consecuencia, Lobato reconoció que la doctrina tomista ha defendido el humanismo del hombre amerindio a través de sus discípulos formados en las escuelas de corte tomista. De hecho, la escuela de Salamanca representó un hito en el proceso de evangelización de América, pero también en la defensa y promoción de sus aborígenes. Como lo señala Lobato: "A pesar de la distancia temporal y geográfica, es muy cierto que Tomás ha sido uno de los arquitectos del hombre amerindio, a través de los discípulos que llevaron la doctrina desde las escuelas de Salamanca a las universidades y centros del nuevo mundo"112.

Tomás de Aquino fue promotor de un modelo de humanismo que es cristiano. Sin embargo, para Lobato la antropología cristiana propuesta por el Aquinate es amplia, es decir, integra diversos aspectos o dimensiones de la vida humana en las que el hombre se realiza, y que se conjugan para su realización plena. Para Lobato:

Tomás ofrece un panorama muy amplio para una antropología cristiana: fundamento cristológico, la predestinación del hombre y del mundo en Cristo, fundamento ontológico, la metafísica del ser creado y por ello compuesto, dependiente, en proceso, homo viator, fundamento axiológico y cultural por el encuentro de dos unidades: la de la naturaleza y la de la persona, el hacerse del hombre en el camino de la aventura humana, del ser libre entre la opción en sus manos, pero sólo por medio de la virtud que el aprender el oficio de ser hombre y el destino que lo trasciende, el fundamento absoluto del destino por la causa final que implica el conformarse con Cristo y convivir con Dios ${ }^{113}$.

De tal manera que para nuestro autor, Santo Tomás ha sido arquitecto de la vida universitaria y del hombre, y no puede estar ausente cuando se piensa en su promoción humana y menos de los centros de formación humana. Por consiguiente, la doctrina del Aquinate continúa siendo fundamental en la cultura actual para la formación humanista integral de la persona:

Con la presencia de la doctrina del Doctor de la Humanidad, no se trata sólo de algo que afecta a Tomás sino de algo mucho más hondo que toca los fundamentos de la cultura actual, y la futura. Tomás no puede estar ausente cuando está en juego el destino del hombre en el tercer milenio, dado que él ha sido uno de los arquitectos del segundo, quizá el de mayor peso específico ${ }^{114}$.

\footnotetext{
112 Ibíd., p. 319.

113 Ibíd., p. 331.

114 Ibíd., p. 366.
} 
No obstante, para Lobato el hombre logra la verdad integral sólo frente a Dios. El hombre es un ser re-ligado a Dios por su origen y su fin último. Para él uno de los problemas del hombre en la cultura actual es enfrentarse a Dios y verlo como enemigo de su libertad o realización. Y no le ha quedado más alternativa para su aparente realización sino la negación de Dios, pero ha quedado sin fundamento o sin sustento. De manera que para Lobato:

Sólo frente a Dios el hombre logra la verdad integral. Por su condición espiritual es teotrópico. La
dimensión religiosa o teologal da sentido a su origen por creación y a su destino de vida eterna en
comunión con Dios. La cultura de la modernidad ha tratado de enfrentarse a Dios como enemigo
del hombre. Sus argumentos son los mismos del 'insipiens' del salmo 13, que se reduce a tres: el
mundo autosuficiente, el de la existencia del mal y el de la libertad del hombre. 'Si Dios existe, yo
no soy libre; pero como yo soy libre... Dios no existe. Dios ha muerto y es preciso darle
sepultura' 115 .

En suma, Abelardo Lobato fue un humanista que además de amar la vida se constituyó en un promotor de la humanidad del hombre, dedicando gran parte de su reflexión a la comprensión del ser humano y de sus miserias -como acostumbra a decir-, pero más de las grandezas, a una vida humana llevada a plenitud. Así mismo, se consideró un discípulo de Tomás de Aquino, de quien conoció a fondo su doctrina y se sirvió e inspiró para el desarrollo del humanismo cristiano. Su ejercicio docente se centró en iluminar los problemas de la cultura actual desde la perspectiva tomista, y con facilidad y creatividad fue capaz de entablar un diálogo entre la cultura moderna y el Aquinate, en el que obtuvo como resultado una reflexión propia y diáfana. En efecto, la vida de Abelardo Lobato fue un servicio en pro de la humanidad del hombre y del pensamiento tomista para el hombre de hoy.

\section{2 Las principales líneas de interés e investigación del pensamiento lobatiano}

Abelardo Lobato se caracterizó por su espíritu de investigador y escritor. El núcleo de su pensamiento siguió tres vertientes fundamentales, a saber: la metafísica, la antropológica y el tomismo. Sin embargo, son diversos los temas que él trató a lo largo de su obra. Muchos de sus escritos son una respuesta a los problemas del hombre de hoy y el diálogo de Tomás de Aquino con la cultura actual. Así mismo, en sus diversos escritos de investigación dejó entrever que cada uno de los problemas planteados son actuales e

${ }^{115}$ Ibíd., p. 546. 
iluminados por la doctrina del Aquinate. De esta manera -como lo indica el bibliógrafo español Gonzalo Díaz Díaz-, los rasgos que van a definir el pensamiento lobatiano son dos:

Por un lado, la filosofía contemporánea que plantea problemas radicales para los cuales no tiene respuesta por estar entrizada en la inmanencia y ser propensa al nihilismo; por otro, la tradición tomista en peligro de anclarse en el pasado y contentarse con meras fórmulas vacías.

Con respecto al primer rasgo, Lobato realiza una crítica filosófica a la falta de fundamentos de la cultura actual. Además considera que la mayor indigencia del hombre en el presente es haberse cerrado a la trascendencia. De manera que para Abelardo:

Es pobre nuestra cultura porque está carente de fundamentos. Nuestra mayor indigencia es habernos quedado en un mundo voluntariamente cerrado a la trascendencia, un mundo que a fuerza de giros en torno al hombre, se torna cada día más inhumano mientras no encuentre la claraboya hacia la trascendencia a que está llamado ${ }^{116}$.

En cuanto al segundo rasgo, para este pensador es importante la fusión de horizontes entre nuestra cultura y el pensamiento tomista. Así mismo, es necesario crear un diálogo fecundo entre el tomismo y la cultura actual que permita construir la verdad y atender los problemas que se van suscitando. Según Lobato:

Todo Tomás está sólo en Tomás mismo. Por ello nuestra lectura de Tomás tiene que ser la propia de nuestra tiempo, la que haga posible la fusión de nuestro horizonte con el suyo y de esa fusión, que nunca es total, resulte la verdad que hoy podemos alcanzar en su estudio ${ }^{117}$.

De manera que para Abelardo dar respuesta a los problemas radicales que se plantea la filosofía actual centra su atención, por una parte, en la filosofía del ser y la antropología desde la paideia tomista, es decir, del ser como acto y del hombre en la unidad substancial de cuerpo y alma. En este sentido -como lo señala Gonzalo Díaz Díaz-, "su obra filosófica se despliega en torno a un núcleo que puede designarse como metafísico-antropológicotomista en las tres direcciones: la ontológica, la antropológica y la tomista (...).

Por otra parte, para no poner en riesgo la doctrina tomista de quedarse anclada en el pasado o que se convierta en un sistema de fórmulas vacías y prevenir su olvido, sigue lo que podemos llamar el método de estudio, comunicación y diálogo que ha sido planteado

\footnotetext{
${ }_{116}^{116}$ LoBAto, A. "La sociedad internacional de Santo Tomás". Vol. 56, Angelicum (1979), p. 6.

117 Ibíd., p. 26.
} 
por la Sociedad Internacional Tomás de Aquino para la difusión del tomismo. Como lo recuerda Lobato: "El proyecto total de la SITA puede desplegarse en tres campos complementarios: la investigación, la difusión y la proyección de Tomás de Aquino"118. De esta manera Abelardo reorienta, potencializa y vitaliza el tomismo para nuestro tiempo.

En cuanto a la investigación del pensamiento tomista señala: "Tomás de Aquino será más actual en la medida que la investigación sobre su época, su persona y su obra sea una realidad de los especialistas de nuestro tiempo" ${ }^{119}$. Sobre la difusión del tomismo manifiesta que es importante, por una parte, dar a conocer las investigaciones realizadas, y por otra parte hacerlo en un lenguaje claro y sencillo. Para Lobato:

La difusión de la obra de Tomás tiene que hacerse a dos niveles: dar a conocer los resultados de la investigación a nivel científico, que es la garantía, y divulgar al alcance de la mayoría, con lenguaje, estilo, presentación del gusto de la hora presente, lo esencial de la doctrina de Tomás $^{120}$.

Finalmente, en lo concerniente a la proyección del tomismo considera importante el diálogo con la cultura actual: "La proyección de Tomás en nuestros días depende de nuestra capacidad dialogante" ${ }^{121}$ De manera que Abelardo ha sido uno de los principales representantes y líderes del tomismo a nivel mundial en el presente siglo. Así mismo, son numerosos los viajes a diferentes partes del mundo en los que se hizo presente con sus reflexiones en torno a Santo Tomás y el humanismo cristiano, a su vez creando la SITA como medio de propagación y enseñanza del tomismo.

En la obra de Lobato son diversos los temas tratados. Muchos de ellos son fruto de las diferentes conferencias, cursos académicos e investigaciones. Igualmente, la crítica a la Modernidad estriba en lo que llamó la falta de fundamentos. No obstante, como tomista su postura fue dialógica y recuperó lo que hay de verdad en su construcción. Además, a lo largo de la obra de nuestro autor se encuentra una constante de sus ideas que las ha ido enriqueciendo con el tiempo, con su experiencia de vida y el diálogo con el pensamiento contemporáneo.

\footnotetext{
${ }^{118}$ Ibíd., p. 27.

119 Ibíd., p. 28.

120 Ibíd., p. 31.

121 Ibíd., p. 35.
} 


\section{2. 1 La categoría 'Tomismo'}

Sinapsis categorial: En la obra lobatiana son abundantes los escritos sobre Tomás de Aquino. Entre ellos tenemos libros, artículos, memorias de congresos, comentarios a la obra de tomista y recensiones, dedicados al conocimiento de la doctrina del Aquinate, a la actualidad de su pensamiento y al diálogo entre el Aquinate y la cultura actual. Entre sus escritos dedicados a la vida y obra del doctor dominico tenemos los siguientes:

"Avicena y santo Tomás en la teoría del conocimiento". Estudios filosóficos. Vol. 5. (1956), pp. 511-552.

La existencia de Dios en santo Tomás de Aquino. Granada: S. Matías, 1957, 118 p.

"Tomaso d'Aquino nel siso VII Centenario". En: Atti del Congresso internazionale. Napoli: Edizione Domenicane Italine, 1974, pp. 274-293.

"Santo Tomás de Aquino hoy". Teresianum. Vol. 25, 1974, núm. 1/2, pp. 5-27.

"Diálogo de nuestro tiempo con Tomás de Aquino". En: El pensamiento de Tomás de Aquino y los problemas fundamentales de nuestro tiempo. Roma: Herder, 1974, pp.7-23.

Il pensiero di Tommaso d'Aquino e i problemi fondamentali del nostro tempo. Roma: Herder, 1974, pp. 536.

"Il pensiero di Sciacca tra Agostino e Tommaso". Incontri Culturali. Vol. 9. (1976), pp. 406422.

"El principio libertad. El dinamismo originario de la voluntad en la cuestión VI De malo de Santo Tommaso de Aquino". En: Doctor Communis: Acta Pontificiae Academiae Romanae S. Thomae Aquinatis et religionis catholicae. Roma: Pontificia Accademia di S.Tommaso, 1977, pp. 33-81.

“El humanismo de la ley según Santo Tomás de Aquino". Verbo. (1977), 16, pp. 79-88.

"Tomismo y antitomismo a lo largo de cien años". En: Atti del convegno organizzato a Roma dalla societa internazionale Tomasso D'Aquino e dalla Pontificia Universita "S. Tomasso D'Aquino". Roma, 1979, pp. 101-136.

"Vigencia de la filosofía cristiana y del tomismo". Angelicum. Vol. 57 (1980), pp. 257-278. 
"San Tommaso, maestro di filosofía cristiana". Idea (1980), pp. 39-46.

"Tommaso d'Aquino e l' «Aeterni Patris». Presentazione". En: Tommaso d'Aquino nel I Centenario dell'Enciclica "Aeterni Patris». (Dirigido por A. Lobato). Roma: SITA, 1981, pp. 7-10.

"Santo Tomás de Aquino en el magisterio de la Iglesia desde la «Aeterni Patris» hasta Juan Pablo II". En: Atti del VIII Congresso Tomistico Internazionale. Roma: Editrice Vaticana, 1981, pp. 7-28.

"La filosofía de santo Tomás y su estructura dialógica". Angelicum (1984), núm. 61, pp. 6395.

"Experiencia y creatividad en Tomás de Aquino" En: Hombre magnánimo y libre. Sevilla: CET, 1984, pp. 261-293.

"Le thomisme de Étienne Gilson". En: Étienne Gilson, filósofo católico. Doctor Communis. (1985), pp. 234-242.

"La cogitativa en la antropología de santo Tomás de Aquino". Journal philosophique (1985), núm. 1, pp. 117-138.

"Maimónides, Averroes y Tomás de Aquino: Diálogo de tres culturas". Communio (1986), núm. 19, pp. 33-64.

"Verdad y libertad: san Agustín y santo Tomás, exégetas de Juan, 8, 32". Doctor Communis. (1986), núm. 39, pp. 329-338.

"L'attualitá di San Tommaso nel pensiero e nell'insegnamento del Santo Padre Giovanni Paolo II". Doctor Communis (1987), núm. 40, pp. 3-28.

L'anima nell antropologi di San Tommaso. En: Atti del Congresso della Societá Internazionale S. Tommaso d'Aquino (SITA). Massimo, Milano, 1987.

"El maestro en teología en el proyecto de santo Tomás de Aquino". Sapientia, vol. 42 (1987), pp. 177-198.

San Tommaso d'Aquino. Opuscoli filosofici. Roma: Cittá Nuova Editrice, 1988, 269 p. 
“Santo Tomás, Magister in Sacra Theologia. El 'principio' de su magisterio". Communio. (1988), núm. 21, pp. 49-70.

"Traduzione, introduzione e note". En: Opuscoli filosofici, L'ente e l'essenza; L'unita dell'intelletto; Le sostanze separate. Roma: Cittá Nuova Editrice, 1989.

"El lenguaje y la palabra en Tomás de Aquino. Santo Tomás, homo Loquens". Revista de filosofía (1989), núm. 65, pp. 132-148.

"Coscienza morale e storicita' dell'uomo in San Tommaso D'Aquino". En: Crisi e risveglio della coscienza morale nel nostro tempo. Roma: Edizioni Studio Domenicano, 1989, pp. 9-46.

"La dignidad del hombre en Tomás de Aquino". Carthaginensia, Vol. 6 (1990), pp. 139-153.

"Las <Quaestiones Disputatae> de Santo Tomás y su aportación a la vida universitaria". Doctor Angelicus (1991), núm. 2, pp. 7-19.

"Il rapporto medico-malato: la dimensione etica secondo San Tommaso". En: Etica dell'atto medico. Bologna: Edizioni Studio Domenicano, 1991, pp. 11-41.

"La humanidad del hombre en Santo Tomás de Aquino". En: San Tommaso d'Aquino Doctor Humanitatis. Studi Tomistici. Libreria Editrice Vaticana, 1991, núm. 40, pp. 51-82.

Juan Pablo II y santo Tomás 'Doctor humanitatis'. Milano: Studia Universitatis S. Thomae in Urbe, núm. 32, 1991, 32 p.

"Fundamento y desarrollo de los trascendentales en santo Tomás de Aquino". Aquinas. Vol. 34 (1991), pp. 203-222.

"El tratado de Santo Tomás de Aquino De motu cordis". En: Littera, sensus, sententia, Studi in onore di C.J. Vansteenkiste. Massimo, Milano, 1991, pp. 341-380.

"El ser y los trascendentales en el pensamiento de santo Tomás de Aquino". En: Veritatem in Caritate. Studi in onore di Cornelio Fabro in occasione del LXXX genetliaco, en Quaderni di Velia, 3, 1991, pp. 118-141. 
"Las <Quaestiones Disputatae> de Santo Tomás fruto de su magisterio universitario". Doctor Communis (1992), núm. 45, pp. 21-45.

"Introduzione". En: Le questioni disputate: testo latino dell'Edizione leonina e traduzione italiana, de santo Tomás de Aquino. Vol. 5. Bologna: Edizioni Studio Domenicano, 1992.

"El 'Novus Orbis' y el hombre nuevo. El triple legado del tomismo del S. XVI. Dignidad personal, comunidad humana y orden jurídico". En: Actas de las Jornadas de la Sociedad Internacional Tomás de Aquino (SITA). Barcelona, 1993, pp. 47-72.

"Presencia e influjo de santo Tomás en la evangelización de América". Doctor communis (1994), pp. 3-39.

"La antropología de santo Tomás de Aquino y las antropologías de nuestro tiempo". En: El pensamiento de santo Tomás de Aquino para el hombre de hoy. Tomo I. El hombre en cuerpo y alma. Valencia: Edicep, 1994, pp. 29-97.

"Introduzione allo studio della vitae delle opere di San Tommaso D'Aquino". En: «Studi 1994. Istituto San Tommaso», Pontificia Università di San Tommaso D'Aquino in Urbe, Roma, 1994, pp. 81-113.

"La situazione degli studi tomistici nel post Concilio attualità ed eclisse, come studiare san Tommaso oggi". En: Istituto San Tommaso Studi (nuova serie 1). Roma: Istit. san Tommaso Roma, 1994, 252 p.

"Fenomenología y metafísica: La filosofía cristiana de Edith Stein y el encuentro entre Husserl y Tomás de Aquino". Aquinas (1994), núm. 37, pp. 335-352.

La liberta' in S. Tommaso. Roma: Pontificia Universitas S.Thomae Aquinatis, 1995, 86 p.

El pensamiento de santo Tomás de Aquino para el hombre de hoy. Tomo I. El hombre en cuerpo y alma. Valencia: Edicep, 1995.

"Filosofía y teología: El uso y el abuso de la filosofía en la teología en las primeras obras de Tomás de Aquino". En: La obra 'San Tommaso Teólogo', a cura di A. Piolanti. Librería Editrice Vaticana, 1995, pp. 59-84. 
"El cuerpo humano en Duns Escoto y Tomás de Aquino". En: Atti del Congresso scotista in ocassione della beatificazione. Roma: Antonianum, 1995, pp. 325-355.

"Itinerario de la Sociedad Internacional Tomás de Aquino en sus primeros 20 años". (Miscellanea), 1995, pp. 24-46.

"Introducción a la edición italiana del <Compendium Theologiae> de Santo Tomás de Aquino". Bologna: Edizione Studio Domenicano, 1995.

"L'inculturazione della fede cristiana in S. Tommaso d'Aquino". Sacra Doctrina, Vol. 41 (1996), Núms. 3/4, pp. 34-80.

"La liberté et l'avenir de I'homme. La perspective thomiste". En: Actas del V Congreso Internacional de Filosofía cristiana. Lublin, 1997, pp. 357-370.

"El compendio de teología de santo Tomás de Aquino". Angelicum. Vol. 74 (1997), núm. 74, pp. 117-127.

"La sociedad internacional de santo Tomás". Angelicum (1979), núm. 56, pp. 3-41.

Santo Tomás de Aquino: Maestro del humanismo cristiano para el tercer milenio. Burgos: Monte Carmelo, 1997, $51 \mathrm{p}$.

"Dic mihi, quid est Deus? Diálogo y disputa de Tomás de Aquino con Averroes y Maimónides en torno al monoteísmo". Communio, Vol. 31 (1998), núm. 2, pp. 225251.

"San Tommaso nella storia della teologia". Sacra Doctrina, Vol. 43 (1998), núm. 2, pp. 99128.

"El horizonte estético del hombre medieval: La perspectiva tomista". Revista española de filosofía medieval. Vol. 6 (1999), pp. 57-68.

"Santo Tomás de Aquino en la formación del dominico del III milenio". Provincia Dominicana de Colombia. El Boletín de los dominicos de Colombia (2001), núm. 111, pp. 65-69. 
"El carisma profético y la teología: El comentario de Hans Urs von Balthasar al tratado de los carismas de santo Tomás de Aquino". Rivista teologica di Lugano, Vol. 6 (2001), núm. 1, pp. 105-122.

"Thomas von Aquin: Lehrer für das dritte Jahrtausend". Doctor Angelicus. Vol. 1 (2001), pp. $16-24$

"Tomás de Aquino maestro para el III milenio". Doctor Angelicus (2001), pp. 9-15.

“La persona en Tomás de Aquino". Ius Publicum (2001), núm. 6, pp. 11-31.

"Tomás de Aquino / 1: apasionada minuciosidad por la verdad del pensamiento". Nuntium, (2001), núm. 4, pp.164-172.

Tomás de Aquino: el santo, el maestro. Madrid: Edibesa, 2001, pp. 152.

El pensamiento de santo Tomás de Aquino para el hombre de hoy. Vol II. El hombre y el misterio de Dios. Valencia: Edicep, 2001.

"El hombre y el misterio de Dios". En: Abelardo Lobato (Ed.), El pensamiento de santo Tomás de Aquino para el hombre de hoy. Vol. II. El hombre y el misterio de Dios. Valencia: Edicep, 2001, pp. 17-31.

"Tomás de Aquino: modelo de quienes buscan la verdad". Doctor Communis (2002), pp. 23-45.

"Introducción". En: QQ.DD. De virtutibus cardinalibus, de santo Tomás. Bologna: ESD, 2002, pp. 26-27.

"El misterio de Cristo y de la iglesia en el comentario de santo Tomás al salmo 44 (45)". Communio, Vol. 35 (2002), pp. 5-34.

"Me brota del corazón un poema bello: comentario al salmo 44 (45) de santo Tomás de Aquino". Communio, Vol. 35 (2002), pp. 35-61.

"Santo Tomás de Aquino y la vía trascendental en filosofía". En: Die Logik des Transzendentalen: Festschrift für Jan A. Aertsen zum 65. Geburtstag, de Martin Pickavé. Berlín: W. de Gruyter, 2003, pp. 163-178. 
"El hombre a la luz del misterio de Cristo". En: Abelardo Lobato (Ed.), El pensamiento de santo Tomás de Aquino para el hombre de hoy. Vol. III. El hombre, Jesucristo y la Iglesia. Valencia: Edicep, 2003, pp. 23-44.

Santo Tomás de Aquino: arquitecto de la vida universitaria. El profesor ideal en la paideia tomista. Bogotá: USTA, 2003, pp. 57.

"Per riscoprire San Tommaso". En: Studi Battista Mondin (2003), pp. 368-373.

"León XIII y el neotomismo". En: León XIII y su tiempo, de José Barrado Barquilla, Ángel Galindo García (Cooord.). Salamanca: Publicaciones Universidad Pontificia, 2004, pp. 397-418.

"El hombre, síntesis de la creación". En: Actas del Congreso "La Síntesis de Santo Tomás de Aquino". Barcelona: Publicacions i Edicions, 2004, pp. 121-138.

L'emergenza storica di San Tommaso" Verbum, Vol. 6 (2004), núm. 1, pp. 7-24.

"La antropología tomista en las QQ. Quodlibetales de santo Tomás". Holanda, Rolduc, SITA, 2004.

"La carta de la Santa Sede sobre los derechos de la familia". Córdoba, SITA, 2004.

“Lectura del libro De Anima de Aristóteles”. Rumanía, lasi, SITA, 2004.

"L'umanesimo cristiano nell III millenio: la prospettica di Tomaso d'Aquino". En: Atti del congresso internazionale 21-25 September 2003, vol. 2. Vatican City: Pontificia Academia Sancti Thomae Aquinatis, Societá Internazionale Tommaso d'Aquino, 2005, pp. 1011.

Homo humanus; Santo Tomás de Aquino, doctor humanitatis: antropología, universidad y humanismo cristiano. Valencia: Universidad Católica de Valencia "San Vicente Mártir", 2005, 37.

"La Pontificia Academia de santo Tomás de Aquino: Historia y Misión". Anuario filosófico. (2006), pp. 309-328.

Tomás de Aquino. Maestro de maestros. Burgos: Monte Carmelo, 2006, 118 p. 
"Lo sacro y la religión en santo Tomás de Aquino": En: Il sacro: fenomenologia, filosofia, teologia, mistica e cultura del sacro: atti della V Sessione plenaria, 24-26 giugno 2005, Città del Vaticano, 2006, pp. 138-153.

"La verdad integral sobre el hombre: la antropología tomista". e-aquinas (2006), núm. 7, pp. 2-9.

Le fonti dell'antropologia tomista. En: Rossi, M. M.; Rossi, T. Persona Humana. Imago Dei et Christi in Historia. Atti del Congresso Internazionale, Roma, 6-8 Settembre 2000, Sentieri» (2002), pp. 235-266.

Le fonti dell'antropologia tomista. En: "Persona humana, imago Dei et Christi, in historia" . Atti del Congresso Internazionale, Roma, 6-8 Settembre 2000. Angelicum Univ. Press, Roma 2002, vol I. pp. 235-265.

Santo Tomas frente a Avicebrón y Averroes. En: Essere e persona: atti della IV Sessione plenaria, 25-27 giugno 2004 = Being and person: proceedings of the IV Plenary session, 25-27 June 2004. Città del Vaticano, 2006, pp. 29-44.

"Cicerone fonte dell'etica di San Tommaso". Aquinói Szent Tamás nyomán (2007), pp. 77100.

"El 'Ave María'. La Expositio de Santo Tomás". Communio, Vol. 40 ( 2007), núm. 2, pp. 141-149.

Cristianismo-Islam: encuentro y diálogo en santo Tomás de Aquino. Sphaera 15. Madrid: CEU Ediciones, 2008, pp. 4-12.

"I trent'anni della SITA. Fondazione, fondatori e attività". En: Studi sul pensiero di Tommaso d'Aquino. In occasione del XXX anniversario della SITA. Roma, 2009, pp. 15-36.

"El ser humano y su alma: introducción al tratado del alma en santo Tomas de Aquino". Angelicum, Vol. 87 (2010), pp. 657-681.

"28 de enero, santo Tomás de Aquino, presbítero, Doctor de la Iglesia, Patrono de las escuelas y estudios católicos”. En: Martínez Puche, J. A. «El año dominicano: 800 años de santidad en la Orden de Predicadores: santos, beatos, venerables y siervos de Dios». Madrid: Edibesa, 2016, pp. 134-151. 


\section{2. 2 Categoría 'Metafísica'}

Sinapsis categorial: Los escritos sobre metafísica de Abelardo Lobato están orientados a la explicación del ser como acto o el acto de ser, que es una intuición propia de santo Tomás. Además es el fundamento en gran parte de su pensamiento, sobre todo en el campo de la antropología, la persona y la dignidad. Para Lobato uno de los grandes olvidos de la cultura moderna es el olvido del ser, por la que el hombre ha quedado encerrado en sí mismo sin apertura a lo trascendente. Entre sus escritos de metafísica están los siguientes:

"La forma sustancial y la unidad del compuesto". Estudios Filosóficos, (1957), núm. 11, pp. 333-337.

“Orden, casualidad y analogía”. Ciencia Tomista (1963), núm. 90, pp. 471-479.

"La belleza en el despliegue nocional del ente". Salmaticensis (1964), núm. 11, pp. 323338.

Ser y belleza. Barcelona: Herder, 1965, 146 p.

Ontología: Pars Prima. Romae: Pontificia Universitas a S. Thoma. Facultad Philosophiae, 1967.

“Metafísica y secularización”. Communio (1971), núm. 4, pp. 145-178.

"Ontología de la persona humana, de Omine". En: Actas del VII Congreso Tomist. Roma, 1971.

"Secolarizzazione, sacralità e metafisica dell'essere". Incontri Culturali. Vol. 5, (1972), pp. 157-176.

"La persona humana en la dimensión ontológica". Acta VII Congressus thomistici internacionalis. Roma: Bibliotheca Pontificiae Academiae Romanae S. Thomae Aquinatis, 1972, pp. 205-209.

La persona: la historia. Perspectivas metafísicas. Roma: Pontificia Universitas A. S. Thoma, 1973, pp. 306

"La densidad ontológica del individuo humano". En: Parola e Spiritu. S. I., Paideia Editrice, 1983, pp. 1383-1410. 
"Antropología y metantropologia. Los caminos Actuales de Acceso al hombre". En: Antropologia e cristologia ieri e oggi 30, $\mathrm{n}^{\circ} 2$ (1987), pp. 175-211.

"Lectura de Averroes de la teoría aristotélica del acto". En: L'atto aristotelico e le sue ermeneutiche. Roma: Herder, 1990, pp. 107-147

"Prólogo". En: Eduardo Forment, Lecciones de metafísica. Madrid: Rialp, 1992, pp. 11-28.

"La dignidad humana desde una perspectiva metafísica". Sapientia (1996), núm. 51, pp. 309-326.

\section{2. 3 Categoría 'Humanismo'}

Sinápsis categorial: Los escritos sobre el humanismo de Abelardo Lobato están orientados a la reflexión de lo humano del hombre, a la dignidad y los derechos humanos. humanismo desarrollado en la obra de este tomista es cristiano. De manera que desde la perspectiva cristiana ofrece pautas para un nuevo humanismo que tiene como modelo la persona de Cristo. Entre sus escritos sobre humanismo tenemos los siguientes:

"Los derechos humanos en el pensamiento contemporáneo". Verbo (1980), pp. 1171-1197.

"La dignidad del hombre y los derechos humanos". Studium (1982), núm. 22, pp. 71-105.

"Los derechos humanos, expresión contemporánea de la ley natural". En: Actualité de la philosophie. Paris: Nouvelles Editions Latines, 1989, pp. 211-246.

"Los derechos del hombre, expresión contemporánea de la ley natural". En: Actualité de la Philosophie. París: Nouvelles Editionis Latines, 1989, pp. 211-246.

"Os direitos humanos e o direito a vida. Por uma Carta dos direitos do embriâo". En $S$. Ladusans Quaestiôes atuais de bioetica. Sáo Paolo: Ediçoes Loyol, 1990, pp. 337360.

"Ecologie et droits humains". Bulletin de l'union internationale des supèrieures générales. (1992), núm. 89, pp. 71-84.

Nuevos horizontes de los derechos humanos. La Iglesia y los derechos de los pueblos". Angelicum (1996), núm. 73, pp. 186-216. 
"La dignidad humana desde la perspectiva ética". Revista Agustiniana (1997), núm. 38, pp. 1065-1092.

"Senderos abiertos hacia el nuevo humanismo". Espíritu (2001), núm. 124, pp. 275-297.

"Nuevos derechos humanos". En: Lexicon: términos ambiguos y discutidos sobre familia, vida y cuestiones éticas. Madrid: Palabra, 2004, pp. 891-904.

\section{2. 4 Categoría 'Antropología'}

Sinápsis categorial: Los escritos antropológicos de Abelardo Lobato tratan diferentes aspectos del hombre, especialmente los relacionados con la persona, la libertad, la verdad, el lenguaje, la familia, la política, la sociedad, ética y moral. Así mismo, se interesó por la comprensión del hombre en todas las dimensiones. De ahí el desarrollo de una antropología integral desde su concepción del hombre como una unidad de cuerpo y alma, del hacerse hombre poniendo en acto las facultades humanas, su crecimiento personal y comunitario por medio de las virtudes humanas y abierto hacia lo trascendente.

"Inteligencia y libertad". Editado por Instituto «Luis Vives» del CSIC. En: III Semana Española de Filosofía, 1957, pp. 321-327.

“El valor y la libertad humana". Estudios Filosóficos (1959), núm. 17, pp. 117-123.

"Primacía de lo intelectual en la comunicación interpersonal". Revista de Filosofía (1962), núm. 21, pp. 84-94.

“La metafísica dell'uomo nella filosofia contemporanea”. Sapientia (1969), núm. 22, pp. 356406.

“L'uomo come soggettività”. Incontri culturali. Vol. 3 (1970), pp. 313-348.

"Soggettività e morale nel pensiero contemporaneo". Incontri culturali. Vol. 3 (1970), pp. 1130.

“El futuro como dimensión humana”. Angelicum (1972), núm. 54, pp. 162-195.

"La persona humana en su dimensión ontológica". En: De homine Studia hodiernae anthropologiae. Acta VII Congressus Thomistici Internationalis. Roma: Officium libri catholici - Catholic book agency, 1972, pp. 205-209. 
"La verdad como conquista humana". En: Sapientia Aquinatis, Vol. II. Roma: Herder, 1972, pp. 205-211.

Hombre y verdad I. Tres concepciones originarias de la verdad. Pontificia Universitas S. Thoma Aquinate in Urbe. Roma, 1972, 287 p.

“El hombre como subjetividad". Revista de filosofía (1973), núm. 13, pp. 53-86.

La pregunta por la mujer. Salamanca: Sígueme, 1976, 283 p.

"Riflessioni filosofiche sulla liberazione della donna". Incontri Culturali (1976), núm. 9, pp. 49-70.

“Uomo e libertá nella dialettica di politica e religione". Incontri Culturali (1976), pp. 406-422.

"Política y religión desde la perspectiva de la libertad humana". Verbo (1977), pp. 159-170.

“Experiencia radical de la libertad". Asprenas (1977), núm. 25, pp. 401-420.

"Le tre dimensioni dell'uomo: essere individuale, sociale, storico". Sapienza, Vol. 34 (1981), pp. 87-149.

"La agonía del lluminismo". En: Scritti in onore di Nicolà Petruzzellis, 1981, pp. 219-266.

"Libertad de expresión y de información en una sociedad democrática". Ecclesia (1986), pp. 26-30.

"El hombre, realidad personal". Actas del II Congreso Mundial de Filosofía Cristiana. Monterrey, México, 1986, pp. 346-356.

"La voz de la conciencia europea". Verbo (1986), pp. 1299-1324.

"Presentazione". En: Antropologia e Cristologia ieri e oggi (Director). Roma: SITA., 1987, pp. 3-6.

“Anima quasi horizon et confinium". En: L'anima nell'antropología di San Tommaso (Studia Universitatis S. Thomae in Urbe, núm. 28), Massimo, Milano, 1987, pp. 52-80.

"L'uomo e la machina". En: Abelardo Lobato (Ed). Homo loquens: Uomo e linguaggio. Pensiero, cervelli e macchine. Bologna: EDS, 1989, pp. 185-210. 
"Presentazione". En: Crisi e risveglio morale della coscienza nel nostro tempo (Director). Bologna: Edizioni Studio Domenicano, 1989, pp. 5-8.

Crisi e risveglio della coscienza morale nel nostro. Bologna: ESD, 1989, 192 p.

"La politica misura d'uomo". En: Coscienza morale e responsabilità politica, a cura di A. Lobato. Bologna: Edizione Studio Domenicano, 1990, pp. 111-137.

"Presentazione". En: Conscienza morale e responsabiltà politica. Bologna: Edizioni Studio Domenicano, 1990, pp. 5-8.

Etica dell'arto medico. Bologna: Edizioni Studio Domenicano, 1991, pp. 199.

Etica e societá contemporanea. Vol. 3 volumini. Librería Editrice Vaticana, 1992, 436 p. “Persona humana”. Vertebración. (1993), núm. 27, pp. 25-40.

"Europa Unita. Utopia o realtà? La filosofia risponde". En: Filosofia e cultura nell'Europa di domani, a cura di G,-B mondin. Roma: Città Nuova Editrice, 1993, pp. 123-131.

"El cuerpo humano". En: A. Lobato, A. Segura, E. Forment, El hombre en cuerpo y alma. Vol. I (1994), pp. 101-335.

"La famiglia umana, icona di Dio". En: La nuova evangeLlzzazione e il personalismo cristiano. Bologna: ESD, 1994, pp. 234-266.

“Amor humano y familia cristiana en el alba del S. XXI". Verbo (1994), pp. 713-759.

"Etica y futuro del hombre". Verbo (1994), pp. 41-71.

"El sentido moral en situación de peligro en la cultura contemporánea". Vertebración. Vol. 7 (1994), núm. 30, pp. 3-12.

"La mujer y el varón cara a cara. El problema de la diferencia". Angelicum (1995), núm. 72, pp. 541-577.

"El sentido moral en situación de peligro en la cultura contemporánea". Angelicum. (1995), núm. 72, pp. 41-61.

"Perdita del senso morale nella cultura contemporanea". En: L'Osservatore romano, 20 de abril de 1955, pp. 273-292. 
"La persona umana, dignità e diritti". En: Siracusa: Zangara Stampa Edittrice, 1996, pp. 3340.

"La paideia exigida por la verdad". En: La formazione integrale domenicana al servizio della Chiesa e della società. Bologna: ESD, 1996, pp. 273-292.

“El problema del hacer humano". Salmaticensis (1996), núm. 13, pp. 283-325.

Dignidad y aventura humana. Madrid: Edibesa, 1997, 273 p.

“Ancianidad y contemplación (I)”. Espíritu (1997), núm. 116, pp. 169-181.

“Ancianidad y contemplación (II)”. Espíritu (1998), núm. 47, pp. 19-30.

"La familia y la Communio Personarum". En: Actas Congreso Internacional. Educación, familia y vida. III: La Familia: comunidad de vida y educación. Murcia: Universidad Católica San Antonio. Pontificio Consejo para la Familia. Santa Sede, 2002, pp.1738.

"El hombre, síntesis de la creación". En: Actas del Congreso "La Sintesis de santo Tomás de Aquino". Barcelona: Publicacions i Edicions, 2004, pp. 121-138.

"Genitoriallidad". En: Lexicon: términos ambiguos y discutidos sobre familia, vida y cuestiones éticas. Madrid: Palabra, 2004, pp. 995-997.

"Personalización". En Lexicon: términos ambiguos y discutidos sobre familia, vida y cuestiones éticas. Madrid: Palabra, 2004, pp. 991-993.

"Persona y procreación integral". En: Lexicon: términos ambiguos y discutidos sobre familia, vida y cuestiones éticas. Madrid: Palabra, 2004, pp. 995-997.

"La familia y los derechos humanos". Familia et vita. Vol. 11 (2006), Núms. 1 / 2, pp. 135140.

"Historicidad del hombre. La dimensión histórica del homo viator". Revista de filosofía. Vol. 7 (2008), núm. 1, pp. 11-28.

“La Familia como 'spiritualis utero'. <Familia et vita>. Vol. 13 (2008), Núms. 2 / 3, pp. 8696.

“El ser y el quehacer político". Albertus Magnus, Vol. II (2009), núm. 2, pp. 121-132. 


\section{2. 5 Categoría 'Cristianismo'}

Sinápsis categorial: Los escritos de cristianismo de Abelardo Lobato están dedicados a temas relacionados con teología y la espiritualidad cristiana. En ellos trata el olvido de Dios en la cultura actual y la relación hombre y Dios. Además, diserta sobre el compromiso cristiano y sus desafíos frente al III Milenio en el proceso de evangelización y catequesis. Así mismo, sobre el papel fundamental de la Iglesia en la promoción del hombre y los derechos humanos. Entre los escritos sobre cristianismo tenemos los siguientes:

"Secularización y Ateísmo". Communio (1965), núm. 1, pp. 453-469.

"Il cristiano nel tempo". En: I/ cristiano nel mondo. Teresianum (1975), pp. 32-55.

“La secularización como problema”. Surge (1977), núm. 35, pp. 174-183.

“Catequesis y pensamiento contemporáneo". Communio (1979), núm. 12, pp. 53-86.

"La filosofía cristiana de la libertad". En: La filosofía del Cristiano, hoy. I Congreso Mundial de Filosofía Cristiana. Córdoba, Sociedad Católica Argentina de Filosofía, vol. III, pp. 1231-1258.

"L'Enciclica Aeterni Patris. Suoi riflessi nel tempo". En: Atti dell'VII Congresso Tomistico Internazionale. Città del Vaticano: Pontificia Accademia di S.Tommaso e di Religione Cattolica, 1981, pp. 496.

"The Task of the christian Philosopher". En: Symposium of the Inter. Congress of Philosophy. Taipei: Fu Jen Catholic University, 1981, pp. 219-226.

"Vida y pensamiento teológico de Edith Stein”. Asprenas (1981), núm. 30, pp. 357-377.

"Experiencia de Dios y palabra humana en Teresa de Jesús”. Angelicum (1982), núm. 59, pp. 323-354.

"La libertad cristiana". En: Actas del I Congreso Internacional de Filosofia. Córdoba, 1982, pp. 357-370.

"Experiencia de Dios y creatividad humana". Miscelánea Bueno Monreal (1983), pp. 426455.

"L'approccio cristiano dei diritti dell'uomo". En: Il diritti dell'uomo e la società. Lipari: Unesco, 1986, pp. 325-345. 
"L'Eglise et les droits de l'homme". En: Les mèdicins et les droits de l'homme. Estrasburgo, 1987, pp. 5-17.

“El nuevo itinerario de la filosofía cristiana”. Teresianum. Vol. 38 (1987), pp. 245-269.

"Edith Stein: el nuevo itinerario de la filosofía cristiana". Teresianum (1987), pp. 245-269.

"La felicidad en el humanismo cristiano". Ateismo e dialogo (1988), pp. 278-284.

"El obispo Garcés y la Bula Sublimis Deus". En: Los Dominicos y el nuevo mundo. Sevilla, 1988, pp. 739-795.

"El rol de la Filosofía en la formación del sacerdote". Seminarium (1989), pp. 37-53.

“Afirmación de Dios. Confirmación del Hombre”. Communio (1990), núm. 23, pp. 3-35.

La Filosofía cristiana en España. Su aportación en los siglos XIX y XX. Gèneve: Culture et Religio, 1990.

Maria modello della donna: antropoanalisi della 'Mulieris Dignitatem'. En: Come si manifesta in Maria la dignità della donna. Roma, 1990, pp. 124-156.

La teologia attuale davanti al «mysterium mortis». Roma: Filosofía e Teologia, 1990.

"Maria modello della donna: antropoanalisis della <Mulieris Dignatem>". En: Come si manifesta in Maria la dignità della donna. Roma: Centro di cultura Mariana, 1990, pp. 124-156.

L'uomo via della Chiesa. Studi in onore di Giovanni Paolo II. Studia Universitatis Sancti Thomae in Urbe 32, Massimo, Milano, 1991, pp. 13-32.

"Struttura personale ed esperienza di Dio". En: Edith Stein, mística e martire, a cura di ÇL. Boriello. Città del Vaticano: Libreria Editrice Vaticana, 1992, pp. 135-170.

"Presencia de san Juan de la Cruz en la filosofía moderna. Simposio del IV centenario della morte". Teresianum (1992), pp. 451-480.

"El eclipse de Dios en la cultura actual de occidente". En: Hombre y Dios en la sociedad de fin de siglo. España: Universidad Pontificia Comillas: Unión Editorial: 1992, pp. 93112. 
Pregón de la Virgen del Rosario. La religiosidad popular y la nueva cultura. Cádiz: Delegación Municipal de Fiestas, 1992, 35 p.

"Gli ostacoli all'incontro con Dio nella cultura odierna". En: L'incontro con Dio,. Bologna: ESD, 1993, pp. 11-35.

“Para qué y para quién es el nuevo catecismo?". Atlántida. (1993), pp. 164-170.

"La religiosidad de Occidente". En: Urena, Manuel; Prades, Javier (Ed). Hombre y Dios en la sociedad de fin de siglo. Madrid: Universidad de Comillas, 1994, 255 p.

Cristianesimo nella posmodernità e paideia cristiana della libertà. Bolonia: ESD, 1994, pp. $416 \mathrm{p}$.

"Itinerarium evangelizationis ieri e oggi". En: La nuova evangelizzazione e il personsalismo cristiano. Bologna: ESD, 1994, pp. 11-44.

"La religiosidad de Occidente en este final del siglo XX”. Espíritu, Vol. 45 (1996), núm. 113, pp. 5-17.

“El silencio de Dios y el Dios del silencio”. Communio (1999), núm. 2, pp. 273-297.

"Jesucristo y el proyecto hombre". En: Actas del IV Congreso Internacional de la SITA IV: Ponencias . Córdoba: Caja Sur, 1999, pp. 297-312.

"El humanismo cristiano frente al tercer milenio". En: Ética y Sociología: Estudios en memoria del profesor José Todolí Duque. Salamanca: San Esteban, 2000, pp. 635644.

"L'umanesimo cristiano alla ricerca del volto umano della globalizzazione". Doctor communis. (2002), pp. 22-32.

"Presentazione". En: Commento al Pater Noster a cura di S.E. Mons. Marcelo Sánchez Sorondo. Città del Vaticano: Pontificia Accademia di San Tommaso d'Aquino, 2002, pp. 3-112.

“El relativismo y la nostalgia del absoluto". Ius Publicum. (2005), núm. 15, pp. 11-19.

"La paideia cristiana de la libertad en la relación interpersonal varón-mujer". Sophia, Colección de Filosofía de la Educación (2007), núm. 3, pp. 33-76. 
"Los desafíos al difícil humanismo cristiano". Communio, Vol. 40 (2007), núm. 1, pp. 169184.

Los preámbulos de la fe cristiana. Murcia: Universidad Católica de San Antonio, 2010, 223 p.

\section{2. 6 Categoría 'Dominicanismo'}

Sinápsis categorial: Los escritos de dominicanismo del Abelardo Lobato están relacionados con los dominicos tomistas y humanistas. Se interesan por subrayar el papel fundamental que ha tenido la orden y algunos frailes predicadores en la evangelización y la promoción del hombre. Entre los escritos sobre dominicanismo tenemos los siguientes:

Vida y obra de Francisco Alvarado, O.P. Sevilla: Edit. Archivo Hispalense, 1955, 88 p.

"Francisco Alvarado y los eclécticos". Estudios Filosóficos (1960), núm. 9, pp. 265-304.

“Itinerario filosófico de R. Garrigou-Lagrange”. Angelicum (1965), núm. 42, pp. 53-116.

"Francisco Alvarado en el Colegio Santo Tomás (1776-1788)". Communio (1979), pp. 351391.

"La Orden de Predicadores en el camino de Puebla". Communio (1980), núm. 13, pp. 71118.

"La dignidad del hombre y derechos humanos en Fray Bartolomé de las Casas y en la doctrina de la Iglesia". Communio (1985), núm. 18, pp. 59-81.

“La dignidad humana en Fray Luís de Granada”. Communio (1988), núm. 21, pp. 415-433.

“Fray Luis de Granada, fraile predicador”. Ecclesia (1988), núm. 12, pp. 6-12.

"Zigliara, filosofo tomista". Angelicum (1988), núm. 65, pp. 241-270.

Giovanni di san Tommaso, O.P, nel IV centenario della sua nascita (1589): il suo pensiero filosofico, teologico e mistico: atti del Convegno di studio della SITA. Roma, 25-28 novembre 1988, $192 \mathrm{p}$.

“Juan de S. T. defensor del tomismo”. Angelicum. (1989), núm. 66, pp. 125-150.

"Fray Luis de Granada, maestro de oración". Anunciata (1989), pp. 74-80.

"La aportación de los dominicos en el S. XVI a la defensa y promoción del hombre". Angelicum (1993), núm. 70, pp. 363-415. 
"La antropología en fray Luis de Granada". En: Fray Luis de Granada. Su obra y su tiempo I: Actas del congreso Internacional Granada, 27-30 septiembre 1988. Granada: Universidad de Granada, 1993, pp. 451-466.

"Filosofía y "Sacra Doctrina" en la escuela dominicana del S. XIII". Angelicum, Vol. 71 (1994), pp. 3-42.

Yo, Juan Macías, amigo de los pobres. Salamanca: San Esteban, 1999, 166 p.

“El papa Juan XXI y los dominicos”. Mediaevalia. Textos e estudios (1995), Núms. 7 / 8, pp. 303-327.

"El obispo P. Francisco Barbado Viejo O. P". En: Semblanzas: Dominicos Béticos para la Iglesia Universal, de O. P. Manuel Uña Fernández, Córdoba: Publicaciones Obra Social y Cultural Cajasur, 2004, pp. 159-187.

"Convento de Almagro". En: Los Dominicos de Andalucía en la España contemporánea I, de Antonio Larios Ramos. Salamanca: San Esteban, 2004, pp. 44-128.

"La Orden de Predicadores y su misión doctrinal". Communio (2001), núm. 34, pp. 263-287.

Vida y obra del padre Francisco Alvarado, O. P. Valencia: Edicep, 2011, 272 p.

III. 2. 7 Categoría 'Anotaciones'

Sinápsis categorial: Los escritos de Abelardo Lobato sobre anotaciones están relacionadas con temas actuales de filosofía y teología. Abordan y desarrollan algunos conceptos claves de pensadores antiguos y modernos. Este dominico fue un pensador atento a los problemas del hombre en la actualidad y sus diferentes reflexiones y aportes a la problemática. Entre sus anotaciones podemos señalar las siguientes:

"La filosofía de Ortega y Gasset”. Ciencia Tomista, Vol. 85 (1958), núm. 266, pp. 313-324.

“En torno a la filosofía de Ortega y Gasset”. Ciencia Tomista (1959), núm. 86, pp. 129-151.

“Diálogo y Disputa: ‘Recontre’ del P. Ramírez con Julián Marías”. Ciencia Tomista (1960), núm. 51, pp. 168-193.

"La polémica en torno a "La filosofía de Ortega y Gasset»". Ciencia Tomista, Vol. 54 (1963), pp. 129-151. 
“Una nueva obra de X. Zubiri”. Ciencia Tomista (1965), núm. 92, pp. 101-104.

"Sobre la esencia: Una nueva obra de X. Zubiri". Ciencia Tomista (1965), núm. 56, pp. 100104.

"La metafísica cristiana de Duns Escoto". En: Acta Congressus de doctrina Duns Scoti. Oxford- Duns, 1967. Vol. II: Problemata philosophica. Roma, 1968, pp. 71-85.

"Grandeza e tragedia dell'uomo nel pensiero di Hegel". Idea (1970), pp. 8-20.

"Persona y naturaleza en Boecio". En: Miscelánea Manuel Cuervo, Salamanca, 1970, pp. 443-471.

"La libertad en el pensamiento de Muñoz Alonso". Incontri Culturale, Vol. 7 (1974), pp. 322342.

"Filosofía e Hispanidad". Angelicum (1977), núm. 54, pp. 240-258.

"El hombre andaluz, sujeto y objeto de la pastoral". Communio (1977), núm. 10, pp. 29-61.

"La persona en el pensamiento de Karol Wojtyla". Angelicum (1979), núm. 56, pp. 165-210.

"La agonía del Iluminismo". En: Scritti in onore di Nicolà Petruzzellis. Nápoles, 1981, pp. 219-266.

"Agustín Basave y el retorno de la Metafísica". En: Homenaje al Doctor Basave. Monterrey (México), 1984, pp. 535-551.

“Presencia y voz femenina”. Revista de filosofía (1987), núm. 60, pp. 438-454.

"Edith Stein e il problema dell'empatia". Studium (1987), pp. 119-121.

"Rosmini e l'idea del progreso". Revista Met., 1987, pp. 235-245.

"La persona eje del humanismo integral de J. Maritain". Angelicum (1987), núm. 64, pp. 628.

"El Obispo Julián Garcés, O.P., y la Bula Sulimis Deus". En: Actas del I Congreso Internacional sobre los Dominicos y el Nuevo Mundo. Sevilla, 21-25 de abril de 1987, Madrid, 1988, pp. 739-795. 
"La situazione degli studi tomistici nel post Concilio attualità ed eclisse, come studiare san Tommaso oggi”. En: Lorenz Dietrich (Ed). Instituto San Tommaso Roma, 1994, pp. 26-38.

"La persona umana nella Veritatis splendor" En: Comento a la VS. Roma: San Paolo, 1994, pp. 352-372

“La nuova fase anno 2000". Doctor communis (2001), pp. 17-37.

"Aproximación a la 'ley natural' en Francisco Suárez S. I.". En: Francisco Suárez y la ley natural: en la frontera de la modernidad, 2010, pp. 39-52

\section{2. 8 Categoría 'Apuntes de clase'}

Sinápsis categorial: Los escritos de Abelardo Lobato sobre apuntes de clase están relacionados con los temas de metafísica, antropología, persona y tomismo. Así mismo muchos de estos escritos se encuentran en máquina de escribir y no fechados. De igual manera, es preciso recordar que toda su vida dominicana la ejerció al servicio de la predicación docente. Entre sus apuntes de clase tenemos los siguientes:

Visione cristiana del creato [ad usum privatum studentium]. Roma, Institutum Mater Ecclecsiae, 1967, $174 \mathrm{p}$.

Commentarium in "De ente et essentia» Sancti Thomae Aquinatis ["ad usum privatum studentium»]. Roma, Pontificia Universitas a S. Thoma, 1968, 128 p.

Hombre y Verdad [«ad usum privatum atudentium»]. Roma, Pontificia Universitas a S. Thomas. I) Tres concepciones originarias de la verdad, 1972, 287 p., II) Tres actitudes de la moderna subjetividad, 1973, $404 \mathrm{p}$.

Ontología. Pars prima [«ad usum privatum studentium»]. Roma, Pontificia Universitas a S. Thoma, 1991, $284 \mathrm{p}$.

Ser personal, Roma, PUST [«ad usum privatum studentium»], 1994, 140 p.

De Hominis dignitate, Roma. PUST [«ad usum privatum studentium»], 1994, 153 p.

Ermeneutica tomistica. II principio della liberta. II dinamismo originario della volontà nella quaestio VI DE MALO di San Tommaso d'Aquino, $63 \mathrm{p}$.

Curso: Antropologia. Roma, 1977. 
Curso: Persona y relación (S. F.)

Curso: El Uno y los muchos (S. F.)

\section{2. 9 Categoría 'Conferencia'}

Sinapsis Categorial: Abelardo Lobato ha sido un gran conferencista. Aunque el público, los lugares y espacios han sido diversos, la gran parte de sus conferencias las compartió en el ámbito de la formación universitaria. Sus escritos de conferencia han quedado mencionados en su autobiografía Abelardo, haz memoria. Las obras y los días. Muchos de ellos posteriormente públicos en diferentes revistas. Aunque algunas están sin fechar y son de diferente índole, podemos agruparlas en seis grandes apartados: 1) Santo Tomás; 2) Antropología; 3) Ética y moral; 4) Política, Sociedad y Familia; 5) Formación Humana; 6) Espiritualidad.

1) Santo Tomás. El ayer y el hoy del tomismo (1998). Actualidad de Tomás (1998). La paideia en Tomás de Aquino: la centralidad de este tema de formar hombres que respondan al proyecto de Dios (1998). El humanismo cristiano. El exigente humanismo tomista para el tercer milenio (1998). La política según Tomás (2001). Santo Tomás arquitecto de la universidad (2001). Tomás a lo largo de la historia, ayer, hoy y mañana (2001). La emergencia de Tomás de Aquino a partir de su canonización en 1323 (2002). Lectura tomista del libro De Anima de Aristóteles (2004). Santo Tomás y el futuro de Granada (S. F.). Los desafíos del posmodernismo y la respuesta del tomismo (S. F.). El ser en Heidegger y en Santo Tomás (S. F.). La filosofía tomista y las bases del quehacer educativo (S. F.). Tomás de Aquino, maestro de pensamiento y de vida universitaria (S. F).

2) Antropología. La mujer y el núcleo de la antropología en nuestro tiempo (1998). La corporeidad (1998). La antropología en nuestros días (1996). La persona en el pensar actual (1996). Dignidad y persona humana (1996). Los derechos humanos, presente, pasado y futuro (1996). Humanismo cristiano (1998). La mujer y su papel en la actualidad (1998). El futuro de la mujer (2001). Dignidad humana y dimensión política del hombre (1998). La cultura en la actualidad (2001). El horizonte metafísico del pulchrum (2004). Los derechos humanos (S. F.). El año de la mujer y el congreso de la ONU en China (S. F.). La promoción de la mujer y la conferencia de Beiging (S. F.). El valor y el carácter inviolable de la vida humana (S. F.). Las diez palabras sobre la mujer (S. F.). 
3) Ética y moral. La crisis actual de la moral y la propuesta de solución en la Veritatis Splendor (S. F.). Los desafíos éticos del presente (S. F.). La defensa de la vida y los problemas éticos de la salud (S. F.). La moral en la vida social y política (S. F.). La teología moral fundamental y los problemas de nuestro tiempo (S. F.). La paz y los derechos humanos en Francisco de Victoria (S. F.). Las relaciones humanas en la empresa (S. F.). La crisis moral de nuestro tiempo: propuestas de solución (S. F.). La educación y la forja de la personalidad (S. F.). La felicidad (S. F.). Reflexiones éticas sobre el valor y la dignidad de la vida humana (S. F.).

4) Política, Sociedad y Familia. La dimensión política del hombre (1998). Servicio social y pobreza actual (1996). Formación moral y espiritual de los hijos (1996). La familia y los derechos humanos (2004). Familia y procreación humana (2004). La familia sujeto de derechos (2001). El rol de la familia en la educación (S. F.). La dimensión política del hombre en Aristóteles y santo Tomás (S. F.). La ecología: relación hombre-mundo en la conciencia actual (S. F.). La familia, núcleo de la vida (S. F.). El proyecto cristiano de la familia (S. F.).

5) Formación humana. La formación en el estudio (1996). El futuro de la libertad (1996). La verdad y la mentira en la información (1996). La educabilidad de la persona (1996). Verdad y libertad (1996). El profesor en la Universidad Católica (1998). La promoción del hombre en la universidad de estilo tomista (1998). La fuerza de la verdad (2001). USTA como uterus spiritualis (1998). La formación: el hombre es el árbol con las raíces hacia arriba (2001) La formación de la personalidad del joven (S. F.). El desarrollo de las virtudes dianoéticas, éticas y artísticas en la adolescencia (S. F.). Juventud, profesión social y futuro humano (S. F.). La humanidad en este fin de siglo y en el alba del tercer milenio: temores y esperanzas (S. F.). La lección de santo Tomás para nuestro tiempo (S. F.). La cultura y los valores (S. F.). Lectura evangélica de los derechos humanos (S. F.). Situación cultural y de Tomás de Aquino (S. F.). El rol del maestro (S. F.). El rol de la ética en la educación (S. F.).

6) Espiritualidad. El quehacer del filósofo cristiano (1979). Las relaciones de la filosofía y la teología en la formación sacerdotal (1996). Vita consacrata (1996). Cómo rezar el Padre Nuestro (1998). La experiencia del Espíritu Santo (1998). Cien años de la doctrina social de la Iglesia (1998). Los retos del tercer milenio y la perenne novedad doctrinal de Tomás de Aquino según la Fides et Ratio (1998). Cristianismo e Islam (2001). La formación dominicana (2001). La razón y la anti-razón en nuestro tiempo (S. F.). 
En resumen, los escritos que conforman la obra y el pensamiento lobatiano son abundantes y de contenido diverso. No obstante, en toda ella encontramos la fuente del tomismo y en diálogo con la cultura actual y los problemas del hombre de hoy. Además, se percibe como escritor la facilidad para abordar y desarrollar los diferentes temas que trata, como la búsqueda de los fundamentos desde el cual son afrontados y de la verdad. Así mismo, un interés por el humanismo cristiano, de la formación del hombre desde la paideia tomista. 


\section{CAPÍTULO IV}

\section{METANTROPOLOGÍA EN ABELARDO LOBATO}

El objetivo del segundo capítulo es analizar los constructos epistemológicos en torno a la concepción de metantropologia en Abelardo Lobato, que permiten la comprensión del humanismo cristiano. El presente capítulo está dividido en dos partes: 1) La incidencia de la vida y obra de Tomás de Aquino en Abelardo Lobato; 2) El horizonte conceptual del pensamiento lobatiano.

\section{1 La incidencia de Tomás de Aquino en Abelardo Lobato}

Tomás de Aquino es el pensador más influyente en la construcción del pensamiento lobatiano. Así mismo, el Aquinate es para Lobato un referente por su personalidad y doctrina. Es así que estos dos aspectos van a incidir en Lobato, en su vida y pensamiento. Pues la imagen que él asume de Tomás es la de teólogo y humanista. De ahí que Abelardo se refiera constantemente a Santo Tomás como Doctor humanitatis. De manera que para Lobato el Aquinate es ante todo un teólogo que hace uso de la razón humana para explicar la realidad bajo la perspectiva divina. Al mismo tiempo de su doctrina crea el concepto de metantropología, como centro y clave de su pensamiento y a partir de él desarrolla y propone una nueva vía de acceso a la comprensión del hombre.

\section{1. 1 Tomás de Aquino como humanista}

La incidencia del pensamiento tomista es fundamental en el desarrollo del pensamiento lobatiano. Además, Tomás de Aquino es el principal maestro o mentor para Abelardo Lobato. De manera que la doctrina lobatiana surge de la lectura asidua, profunda y en su contexto histórico del pensamiento tomista como de su enseñanza y diálogo con la cultura moderna y sus problemas. Es así que refiriéndose al Aquinate, afirma Lobato: "pienso que toda mi obra brota como agua de ese manantial inagotable" ${ }^{122}$. En efecto, si uno de los criterios para conocer la incidencia que ha tenido el pensamiento de un autor sobre la obra de otro se mide por el número de notas marginales, el pensamiento tomista aparece como referente constante en la obra o escritos de Abelardo Lobato.

Ahora bien, el horizonte del pensamiento lobatiano es el humanismo cristiano al que une la metafísica y el tomismo. Al decir del mismo Lobato: "Al horizonte de lo humano, se unen los

\footnotetext{
${ }^{122}$ LoBATO, A. Abelardo, haz memoria. Las obras y los días. Op. Cit., p. 113.
} 
otros dos, el de la metafísica y el del tomismo. Y los tres bien ensamblados" ${ }^{123}$. Con respecto a Tomás de Aquino, uno de los nombres a los que refiere constantemente Abelardo es el de Doctor humanitatis. Sin embargo, este título o reconocimiento le fue otorgado por san Juan Pablo II en el VIII Congreso Tomista Internacional, celebrado en Roma con ocasión del centenario de la Encíclica "Aeterni Patris", el 13 de septiembre de 1980. A este propósito comentó Lobato:

Para Juan Pablo II, Tomás merece este título de Doctor humanitatis porque además de haber develado los fundamentos de la humanidad del hombre, ha sabido comprender, en su ejercicio de carisma de teólogo de la Iglesia, la profunda raíz de la humanitas desde la luz de la fe que devela el misterio de Dios y la relación profunda del hombre con la divinitas. El misterio del hombre se devela mejor a la luz del misterio de Dios ${ }^{124}$.

Es probable que Lobato se dirigiese constantemente al Aquinate con este título y se debía a que consideraba que era el que mejor definía la personalidad de santo Tomás. Sin embargo, para Abelardo el humanismo tomista y la comprensión del título de Doctor humanitatis hay que hacerlo desde Tomás como Doctor divinitatis, es decir, en su vocación de teólogo que le permite penetrar en el fondo de la humanitas del hombre. Es así que para Lobato:

Por todo ello es claro que Tomás sigue siendo ante todo el Doctor divinitatis. Y es ahí donde adquiere su plano y cabal sentido el nuevo título de Doctor humanitatis, porque sólo desde una visión teológica se comprende bien su amplio tratado De homine, concebido en el marco del tratado de Dios Creador, y por ello ve al hombre como obra de las manos de Dios, hecho a su imagen y ordenado a la plena participación de la vida divina ${ }^{125}$.

Conviene subrayar una vez más que para Abelardo Lobato el Aquinate es un teólogo por vocación y que, por ende, su pensamiento es teológico. Así mismo su existencia es teotrópica, un buscador de Dios. Para Lobato, "Tomás ha sido un hombre de fe profunda y ha tenido el don de una inteligencia privilegiada que ha puesto al servicio de la fe"126. Sin embargo, la novedad del pensamiento tomista estriba en la distinción y el horizonte en el

\footnotetext{
${ }^{123}$ Ibíd., p. 112.

124 LoBATO, A. Juan Pablo II y santo Tomás "Doctor Humanitatis". Milano, Italia: Studia Universitatis S. Thomae in Urbe, 1991, p. 23.

${ }^{125}$ Idem.

${ }^{126}$ LobATO, A. "El hombre y el misterio de Dios". En: LoBATO, A. (Dir.)y otros. El pensamiento de Santo Tomás de Aquino para el hombre de hoy. Vol. II, El hombre y el misterio de Dios. Valencia, España: EDICEP, 2007, p. 25.
} 
que teje lo humano y lo divino. De ahí que su obra sea una síntesis que sólo logra hacerla desde la perspectiva teológica en la comprensión de la realidad como totalidad.

Para Lobato, Tomás debe ser contado entre los grandes antropólogos de la humanidad y esto se debe a tres perspectivas que merecen ser tenidas en cuenta, a saber: 1) por realizar en sí mismo un admirable modelo de vida humana; 2) por ocuparse en alcanzar durante su vida una comprensión cabal del hombre; 3) por dejar a la posteridad un legado doctrinal humanista. Estas tres perspectivas son tratadas y desarrollas por el autor español en su libro que lleva por título El pensamiento de Tomás de Aquino para el hombre de hoy, donde presenta una síntesis del pensamiento tomista y a su vez en diálogo con la cultura actual. Estas tres perspectivas de la personalidad del Aquinate son las que van a incidir en la vida y obra de Abelardo Lobato

En primer lugar, para él: "Tomás es un hombre en plenitud"127. El Aquinate es modelo de plenitud humana por el desarrollo personal de las virtudes humanas y teologales. Así mismo éstas fueron forjadas por la respuesta a su vocación humanista, cristiana y dominicana que se concretizó en la santidad de vida y sapiencia cristiana. De modo que para Lobato: "Santo Tomás de Aquino merece ser conocido, porque es uno de los más ilustres ejemplares de la humanidad" ${ }^{\text {"28 }}$. De donde resulta que santo Tomás no era sólo un teórico de la vida moral del hombre sino que escribió lo que vivía. Igualmente, para Abelardo el Aquinate desarrolla su propia humanidad y sus capacidades y por ello se convierte en modelo de vida, al punto que según este pensador:

El hombre en plenitud es posible pero raro. No tenemos una receta para producirlo, ni puede ser fruto de las circunstancias. El hombre que llamamos genial es un milagro de la Naturaleza y de la Gracia. Son bien contados los genios que han aparecido en la historia. Tomás de Aquino es uno de ellos, uno de los más grandes ${ }^{129}$.

Entre todos los aspectos humanistas por los que se caracterizó la grandeza de Tomás, el que más se resalta es la pasión por la verdad. Al decir de Abelardo: "la pasión superior del hombre es la verdad. Tomás la ha vivido y ha quedado fascinado" ${ }^{130}$. Además, para Lobato: "Tomás era respetuoso con los pensadores, pero sólo se dejaba vencer por la

\footnotetext{
${ }^{127}$ LoBATO, A. "La antropología de Santo Tomás de Aquino y las antropologías en nuestro tiempo". En: Lobato, A. (Dir.) y otros. El pensamiento de Santo Tomás de Aquino para el hombre de hoy. Vol. I, El hombre en cuerpo y alma. Valencia, España: EDICEP, 1995, p. 32.

128 Lobato, A. Santo Tomás de Aquino. Maestro de maestros. Burgos, España: Monte Carmelo, 2006. p. 5. ${ }^{129}$ Idem.

130 LoBATo, A. "Tomás de Aquino, modelos de quienes buscan la verdad". Ius Publicum. (2002), núm. 8, p. 18.
} 
verdad que recoge dondequiera que la encuentre, convencido de que siempre procede del Espíritu Santo" ${ }^{131}$. En efecto el Aquinate estaba convencido de la fuerza invencible de la verdad.

En segundo lugar, para Lobato, "Tomás es también un pensador sobre el hombre"132. Para el Aquinate -en su pasión constante por la verdad-, el hombre siempre ocupó en su pensamiento un lugar principal. Más aún: Tomás abordó el tema del hombre a lo largo de su vida y obra. Aunque en su vocación de teólogo se centró en el misterio de Dios, no obstante se preocupó de un modo constante en dar una respuesta al problema del hombre. El hombre es comprendido a la luz del misterio de Dios; en efecto, es una antropología teológica integral. De manera que para Lobato: "La visión antropológica de Tomás es siempre teologal y teocéntrica" ${ }^{\text {"133. }}$.

Tomás de Aquino incorporó los datos de la Revelación y de la tradición cristiana a su síntesis antropológica: Dios formó al hombre del barro de la tierra; en la plenitud de los tiempos el Verbo se hizo carne, y la resurrección del hombre en Jesucristo será integral. En clave lobatiana, la visión tomista del hombre desde la teología es integral, un aspecto muy importante para Lobato porque incorpora y salvaguarda todas las dimensiones del hombre. Además, en comparación con la antropología moderna, para éste: "La antropología tomista propone una comprensión del hombre como imago Dei, como fin del universo, y como sujeto personal que se va haciendo en la medida en que se conforma con el hombre en plenitud que es Jesucristo"134.

Finalmente, en tercer lugar, para Lobato, "Tomás presenta una doctrina sobre el hombre, una antropología bien fundada"135. Tomás de Aquino es consciente de que el hombre es un ser muy complejo en su estructura. De ahí el interés del español por las imágenes que usa Tomás cuando se refiere al hombre, para abordar su complejidad y como vías de acceso. Entre ellas, las que más llaman la atención son: la imagen del hombre como microcosmos y la de horizonte o confín. De manera que la primera imagen antropológica que usa el

\footnotetext{
${ }^{131}$ LoBATO A. "Dic mihi, quid est Deus? Diálogo y disputa de Tomás de Aquino con Averroes y Maimónides en torno al monoteísmo". Communio (1998), núm. 2, p. 229.

132 LoBATO, A. "La antropología de Santo Tomás de Aquino y las antropologías en nuestro tiempo". Op. Cit., p. 32.

${ }^{133}$ Lobato, A. Juan Pablo Il y Santo Tomás "Doctor Humanitatis". Op. Cit., p. 23.

134 LobATo, A. "El hombre, síntesis de la creación". En: José M. Petit Sullá - José M. Romero Baró (Eds.). Actas del congreso, La síntesis de santo Tomás de Aquino. Barcelona: Publicacions i edicions de la Universitat de Barcelona, 2002, p. 124.

${ }^{135}$ LobATO, A. "La antropología de Santo Tomás de Aquino y las antropologías en nuestro tiempo". Op. Cit., p. 33.
} 
Aquinate es de Demócrito y la segunda del neoplatonismo. Es así que para Tomás de Aquino el hombre viene siendo el punto de encuentro de los diversos seres de la creación. Pero además, para Lobato al teólogo Tomás le interesa la imagen del hombre como imagen de Dios revelada en la persona de Jesucristo. Porque el hombre se comprende a la luz de Dios, del misterio de la Encarnación, como centro de la revelación. De manera que para Abelardo las dos fuentes de la doctrina humanista de Santo Tomás son la razón humana y la iluminación divina, de donde surge un nuevo humanismo tejiendo la humanitas con la divinitas. Para Lobato: "La aportación más valiosa de Tomás a la cultura es la de

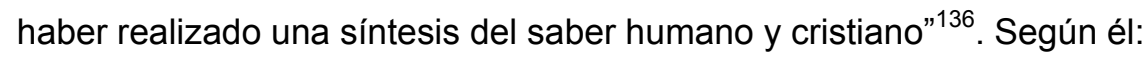

Para Juan Pablo II, Tomás de Aquino merece en justicia este título porque ha sabido develar los fundamentos de la humanidad del hombre, ha encontrado las profundas relaciones que lo unen con Dios, y como teólogo de la Iglesia, ha enseñado a los hombres los lazos que unen la humanitas con la divinitas ${ }^{137}$.

\section{1. 2 El humanismo en el pensamiento tomista}

Para Abelardo Lobato el nombre de Doctor humanitatis es el que mejor define la personalidad o vida del Aquinate. De modo que una vez tratado el humanismo en la persona de Tomás es importante resaltar con Abelardo la palabra humanitas en el pensamiento tomista. De igual manera para Lobato -por ser Santo Tomás teólogo- el humanismo que presenta es teológico y éste de carácter cristiano. De ahí que Abelardo desarrolló el humanismo cristiano en el Aquinate y a su vez constituyó el horizonte de su pensamiento como él mismo lo manifiesta.

Abelardo señala que la palabra humanitas se encuentra al menos en 753 textos de santo Tomás de Aquino. Además la humanitas tomista ofrece diversidad de sentidos, entre los que distingue Lobato los siguientes: lógico, cultural, histórico, filosófico y teológico. De modo que en lo humano del hombre -en sentido lógico- es substancia; en sentido cultural es filántropo; en sentido histórico es caminante; en sentido filosófico es alma y cuerpo; en sentido teológico es capaz de $\operatorname{Dios}^{138}$. Así que para Lobato el concepto humanitas no es ajeno ni está ausente en la vida y obra de santo Tomás.

\footnotetext{
${ }^{136}$ Lobato, A. "El hombre y el misterio de Dios". Op. Cit., p. 21.

${ }^{137}$ LOBATO, A. "La antropología de Santo Tomás de Aquino y las antropologías en nuestro tiempo". Op. Cit., p. 35.

${ }^{138}$ Cf. Ibíd., p. 56.
} 
No obstante, desde la lectura de Abelardo a la humanitas tomista hay que tener presente dos ideas importantes: la primera es que este vocablo latino es un constructo abstracto del hombre concreto; la segunda es que al Aquinate le interesó es la humanitas teológica. De ahí que para Lobato, "la humanitas de la cual Tomás es Doctor y el orientador cultural para nuestro tiempo, es sólo un abstracto del concreto homo, el cual se realiza en modos diversos en cada uno de los individuos singulares existentes"139. De manera que no existe el hombre platónico porque no es persona singular y sensible. El hombre del Aquinate es de cuerpo y alma o un cuerpo viviente.

El humanismo tomista además de ser teológico integra los demás sentidos de su antropovisión. La humanidad es para él el lugar privilegiado de todo lo creado como propósito para Dios manifestarse. Esto ha sucedido de modo superlativo al asumir nuestra humanidad en la persona de su Hijo Jesucristo. Al decir lobatiano:

Pero lo que a Tomás le interesa en la humanitas es el sentido teológico, que integra y supera todos los anteriores porque los abraza en una sola visión. Desde esta perspectiva la humanitas es el lugar privilegiado de la presencia de Dios en su obra del mundo visible ${ }^{140}$.

Tomás es un teólogo por vocación. Por lo tanto, la realidad es asumida desde una visión teológica sin desestimar los aportes de los diferentes pensadores de su tiempo. Es decir, el hecho de que sea abordado el hombre desde una perspectiva teologal es por su perspectiva de totalidad e integradora. Según el teólogo español:

La vía teológica, la que se propone ver las cosas desde Dios, es para Tomás la decisiva, porque es el modo de alcanzar la verdad toda entera del hombre, y ésta es la vía que Tomás ha elegido para su oficio de maestro. Desde la revelación se obtiene la visión del ser humano desde arriba, en orden descendente ${ }^{141}$.

La anterior es una idea constante en Abelardo cuando se refiere a santo Tomás y su pensamiento. Es así como reafirma una vez más el humanismo teológico del italiano:

Pero sobre todo, Tomás ha sabido penetrar a fondo en la humanitas del hombre, porque ha sido fiel a su vocación teologal, por la cual estaba llamado a ser hombre que habla de Dios y penetra, con la luz de la fe y el esfuerzo de la razón, en sus misterios. Su tarea es ver las cosas en Dios y

\footnotetext{
139 Idem.

${ }^{140}$ Idem.

141 LOBATO, A. "El horizonte estético del hombre medieval. La perspectiva tomista". Revista Española de Filosofía Medieval. (1999), núm. 6, p. 61.
} 
desde Dios. Nada se escapa a la comprensión del teólogo cuando ha sabido comprender su tarea de penetrar en el misterio de Dios $^{142}$.

En la antropovisión tomista el hombre es imago Dei y capax Deus. Para Lobato: "Tomás teólogo descubre el humanismo integral, el que se revela en Jesucristo, imago Dei, y se participa en todos los hombres, creados por Dios a su imagen"143. De modo que el hombre ha sido creado para relacionarse con su Creador por el conocimiento y el amor. Además la relación con Dios se constituye para el hombre en originaria, fundante y terminal. Todo sale de Dios y vuelve a Él, como lo desarrolla el Aquinte en su exposición teológica circular del exitus y reditus. Más aún, se hace superlativa en la persona de Cristo, la revelación plena de Dios. De modo que la humanitas tomista y su sentido teológico es una humanitas Christi. De esta manera surge uno los conceptos importantes en el pensamiento lobatiano: el humanismo cristiano.

\section{1. 3 La antropología tomista}

La concepción tomista del hombre es otro de los aportes fundamentales de la doctrina de santo Tomás al pensamiento lobatiano. Abelardo señala dos ideas importantes de acceso a la comprensión antropología del Aquinate: la primera es la comprensión que había acerca del hombre en su tiempo; y el segundo las vías para su conocimiento. Con respecto al primer aspecto, para Lobato:

Tomás se encontró con dos tipos de comprensión de hombre: uno que atendía más a la dimensión espiritual de ascendencia platónica; otro que indagaba la esencia de lo humano desde la base de la experiencia y la comunión con los demás seres del cosmos y se inspiraba en Aristóteles $^{144}$.

Para Abelardo el Aquinate acogió lo que hay de verdad en los pensadores griegos y lo incorporó a sus antropovisión. De manera que para Lobato:

Con los platónicos da preferencia a la dimensión espiritual del alma, pero se separa netamente de esa corriente al incluir la corporeidad en la esencia del hombre. Con los aristotélicos defiende la concepción del alma como forma del cuerpo, pero contra la deformación averroísta rechaza la

\footnotetext{
142 Lobato, A. Juan Pablo Il y Santo Tomás “Doctor Humanitatis”. Op. Cit., p. 22.

143 LOBATO, A. "El horizonte estético del hombre medieval. La perspectiva tomista". Op. Cit., p. 61.

${ }^{144}$ LobATo, A. "La antropología de Santo Tomás de Aquino y las antropologías en nuestro tiempo". Op. Cit., p. 56.
} 
teoría del alma única para todos los hombres, y hace del entendimiento y voluntad facultad del alma $^{145}$.

En cuanto a la segunda idea es que las vías de acceso a la comprensión del hombre son la vía ascendente y la vía descendente. La primera es propia del filósofo y la segunda es del teólogo. Aunque Tomás ha optado por la vía teologal no descarta la primera pues considera que las dos son necesarias y complementarias. De manera que Abelardo hablando de estas dos vías de acceso para el conocimiento del hombre en el Aquinate comenta:

La primera es la que compete al filósofo de la naturaleza, que ve al hombre en las relaciones que tiene con los cuerpos y los vivientes y en la peculiaridad que lo distinguen de estos grados del ser. La segunda es más propia del teólogo, que comprende al hombre desde el plan de Dios, quién lo ha creado y lo dirige hacia una vida de plena unión con él. Tomás ha preferido esta vía, pero no ha olvidado la primera ${ }^{146}$.

En Tomás de Aquino -por ser teólogo- su antropología tiene raíces bíblicas, es decir, semita y cristiana. Al mismo tiempo asume la comprensión del hombre, como se ha indicado con Lobato, el conocimiento antropológico que se tiene en la cultura árabe y griega. De manera que para Lobato el Aquinate estuvo siempre atento a todo lo que se ha dicho con respecto a la humanidad del hombre para dar una respuesta sobre su verdad integral. A este propósito afirmó el español:

Tomás, atento a la humanitas del hombre, escudriñador profundo de sus sentidos, no podía dejar pasar de largo esta visión de totalidad que le proporciona la revelación en diversos lugares. El salmo 8 es el lugar clásico de la pregunta y la respuesta por lo humano del hombre. Tomás en búsqueda de la humanitas del hombre ha encontrado en el salmo la verdad integral del hombre ${ }^{147}$.

Del Aquinate es preciso resaltar la capacidad de síntesis al momento de tratar los diferentes temas, entre ellos el del hombre. De igual manera, Tomás siempre busca bases sólidas o fundamentos para su comprensión antropológica integral e incluso recurre no sólo a lo que ya se ha dicho sino a lo que hay de verdad. Al decir de Lobato, "la antropología

\footnotetext{
145 LoBATO, A. "El hombre, síntesis de la creación". Op. Cit., p. 133.

${ }^{146}$ LoBATO, A. "La antropología de Santo Tomás de Aquino y las antropologías en nuestro tiempo". Op. Cit., p. 37.

${ }^{147}$ Ibíd., p. 55
} 
tomista, elaborada a partir de tres fuentes, bíblica, aristotélica y neoplatónica, es uno de los pilares más sólidos del tomismo, a la par de su metafísica y de su teología” ${ }^{148}$.

En efecto, desde la perspectiva bíblica el hombre es un compendio de la obra creadora. Al mismo tiempo el hombre ha sido creado a imagen y semejanza de Dios y re-creado en la persona de Jesucristo, quien es la imagen plena de Dios y la imagen de Dios para el hombre. De esta manera para Lobato:

El hombre pleno se ha realizado de modo perfecto en dos ejemplares diferentes: en el primer ser humano, creado por Dios a su imagen y semejanza (Gen 1, 26,28), y de modo singular en Jesucristo, la plena imago Dei en el mundo. Adán y Eva al principio, Jesucristo en la plenitud de los tiempos. Tomás propone a todos los hombres el itinerario humano de conformarse con Cristo para esa plenitud de lo humano ${ }^{149}$.

Desde la perspectiva aristotélica, el Aquinate aplicó al hombre la teoría del alma como forma del cuerpo, que había sido ideada por Aristóteles, pero no en todo su rigor se había aplicado a la concepción de hombre. Para Lobato, "la gran contribución de Aristóteles fue la definición del alma como acto primero del cuerpo físico orgánico, y la aplicación del hombre de la teoría hilemórfica" ${ }^{150}$. De modo que Tomás, al asumir y aplicar los aportes antropológicos del Estagirita a su concepción de hombre, lo concibe como una unidad sustancial de alma y cuerpo. Efectivamente, explicando la antropología tomista afirma Lobato, "en el hombre hay unidad de ser, dualidad de principios, y una infinidad de componentes" 151 .

Para Tomás de Aquino el hombre es cuerpo y alma. Sin embargo -como lo señala Lobato-, para el Aquinate la corporeidad está constituida desde la forma. Es que para Tomás lo decisivo en su antropología es la comprensión de la forma. De modo que para Lobato:

Confluyen en esta concepción de la espiritualidad del hombre, a través de la teoría del alma humana, forma sustancial del cuerpo, tres grandes aportaciones tomistas a la antropología: en primer lugar la teoría del ser como acto, que hace posible la diferencia de los entes y funda al singular concreto; en segundo lugar la aplicación al hombre de la teoría hilemórfica, que había sido ideada por Aristóteles, pero no había sido aplicada en todas sus consecuencias, y en tercer

\footnotetext{
148 LoBato, A. El hombre, síntesis de la creación. Op. Cit., p. 124.

${ }^{149}$ Ibíd., p. 137.

150 LOBATO, A. "La antropología de Santo Tomás de Aquino y las antropologías en nuestro tiempo". Op.

Cit., p. 105.

${ }^{151}$ Ibíd., p. 127.
} 
lugar, que el alma humana sea forma substancial única del cuerpo, pero no sea forma material sino forma espiritual y por ello forma emergente en medio del cosmos ${ }^{152}$.

Además, Tomás retoma la imagen del hombre en la tradición griega como microcosmos para resaltar su inserción en el mundo: el hombre es un mundo en pequeño. Al decir de Lobato, "el hombre puede ser designado como microcosmos, parvus mundus, como lo han designado los griegos después de Demócrito, de quien lo toma Aristóteles, porque realiza en miniatura lo que constituye el mundo en su tamaño natural”153 .

Al mismo tiempo, hablando de la imagen antropológica del hombre como microcosmos, afirma Lobato: "la más antigua que recoge Aristóteles y será muy del gusto de los medievales, designar al ser humano como mikrokosmos, mundo menor en medio del gran mundo" ${ }^{154}$. También desde la perspectiva neoplatónica el Aquinate acogió la imagen antropológica del hombre como horizonte o confín. Así lo indica Lobato:

La segunda imagen procede del mundo neoplatónico, el que concibió el cosmos como cascada descendente que plurifica la unidad irrompible del ser primero y más alto. Del uno brotan las inteligencias, el alma y el universo de los cuerpos. En esta perspectiva el hombre fue concebido como confín de dos mundos, como horizonte ${ }^{155}$.

Abelardo señala que para el Aquinate la imagen del hombre como horizonte es fundamental porque le sirve para distinguir y unir la materia y el espíritu. Según Lobato:

Por ello Tomás de Aquino ha apreciado la imagen de los neoplatónicos del hombre como horizonte, un confín en que se encuentran de modo real y bien trabado los don niveles del ser, el de la materia y el del espíritu, con todas sus implicaciones ${ }^{156}$.

Otra de las imágenes antropológicas propias del Aquinate y que le gustó resaltar a Lobato es la postura erguida del hombre. Para Lobato, "el hombre es un animal erecto, y en esto se distingue de los demás animales" ${ }^{157}$. De igual manera, siguiendo esta imagen antropológica tomista, según el español, "el hombre es como un árbol con la raíces hacia arriba, y como un animal pero con los sentidos en lo alto. La verticalidad es su privilegio" ${ }^{\text {158. }}$

\footnotetext{
152 Ibíd., p. 43.

${ }^{153}$ LOBATO, A. "El hombre, síntesis de la creación". Op. Cit., p. 128.

154 LoBATO, A. "La dignidad del hombre y los derechos humanos". Studium, Vol. 22, (1982), fasc. 1, p. 86.

155 lbíd., p. 87.

${ }^{156}$ LOBATO, A. "La antropología de Santo Tomás de Aquino y las antropologías en nuestro tiempo". Op. Cit., p. 33.

157 Ibíd., p. 145.

${ }^{158}$ LOBATO, A. "El horizonte estético del hombre medieval. La perspectiva tomista". Op. Cit., p. 64.
} 
Además de la postura erguida de la corporeidad humana, para Tomás de Aquino hay tres órganos del cuerpo a los que ha dedicado una especial atención en su reflexión antropológica y son -según Lobato-, las manos, la cabeza y el corazón. Las manos son una forma de expresión de la humanidad, que se manifiesta externamente en su obra. Comentando la importancia de las manos en la vida del hombre -según Santo Tomás-, comenta Lobato:

En el cuerpo humano tienen gran importancia las manos por los servicios que presta al hombre. Con ellas tiene que procurarse todo lo que la naturaleza dio a la los animales y negó al hombre, como son las defensas, la dureza de la piel, los cuernos, la abundancia de pelos y plumas, que no son compatibles con la delicadeza de la complexión humana que debía aumentar la sensibilidad. Las manos son el precioso instrumento para que el hombre supere a los animales en la preparación del vestido, la comida, la casa y la defensa ${ }^{159}$.

Sobre el órgano del corazón, el médico Felipe de Castriocelo -amigo de Tomás- le preguntó cómo se movía el corazón del hombre, porque al parecer todo procedía de este movimiento, además quién lo movía a él, puesto que no estaba claro si era un movimiento natural o voluntario. A lo que el Aquinate respondió con Maimónides que el movimiento del cuerpo lo da el corazón; con los platónicos responde que el movimiento del corazón y del hombre lo da el alma como principio de movimiento o de vida; como teólogo el alma es creada a imagen y semejanza de Dios. Sin embargo, en la síntesis de respuesta que Tomás elaboró concluyó con la perspectiva teológica originaria del alma, es decir, su origen divino, como lo expresa Lobato:

La vida es movimiento, y el alma es el principio de lo que se mueve en el hombre. El cuerpo humano se mueve por el movimiento del corazón, pero este movimiento, que es tan importante porque de él dependen cosas como el calor humano, los espíritus, los sentimientos, y el movimiento de todo lo corporal, está originado por el alma, creada por Dios ${ }^{160}$.

Pero -al decir de Abelardo-, Tomás hace además una distinción de la importancia y la primacía entre el órgano del corazón y la cabeza en la corporeidad del hombre. De manera que en el movimiento corporal prima el corazón y en el cognoscitivo la cabeza. Como lo señala Lobato:

En relación con el movimiento tiene primacía el corazón y por ello lo acepta como el órgano primario de todo lo referente al movimiento, y también a la vida afectiva, que tiene tanta parte en

\footnotetext{
${ }^{159}$ Ibíd., p. 145.

${ }^{160}$ LOBATO, A. Dignidad y aventura humana. Salamanca: Edibesa, 1997, p. 247.
} 
la vida humana y en la vida cristiana. Pero en relación con la vertiente cognoscitiva tiene primacía la cabeza, porque en ella se dan todos los sentidos, exteriores e interiores, a excepción del tacto que se encuentra distribuido por todo el cuerpo ${ }^{161}$.

\section{1. 4 El hombre es por naturaleza animal político y social}

Otra de las ideas de la antropología tomista comentada y desarrollada por Lobato es del hombre como animal político. Más aún, para éste el hombre por naturaleza se descubre como un animal político. De manera que la política se refiere al hombre en relación con la polis o ciudad. Según Lobato, "el animal político se propone como fin supremo el bien de los que forman la comunidad humana. La colaboración hace posible la paz y la felicidad de todos y cada uno de los miembros"162. De modo que para Lobato es importante resaltar con Tomás de Aquino el bien de todos las personas que conforman la sociedad: el bien común.

Las relaciones interpersonales del hombre en la ciudad dan origen a la vida social. Según Lobato la vida social del hombre para Tomás de Aquino se da por naturaleza, pero al mismo tiempo por la complexión o estructura corporal, es decir, "a diferencia de todos los demás animales el hombre vendría al mundo descalzo, desnudo, desarmado"163. Así que en sociedad es como el hombre puede satisfacer sus deseos y necesidades espirituales y corporales. Al decir de Lobato:

Tomás expone la doctrina sobre el hombre como "animal social" por naturaleza. Hay animales gregarios, como las abejas, las hormigas, las ovejas, las grullas; pero el hombre lo es mucho más. En vez de los instintos de los animales, el ser humano tiene la razón. Pero no puede por sí solo responder a todo lo que necesita para sobrevivir. Ésta es la señal de que la naturaleza lo inclina a convivir en sociedad, para remedio de su indigencia ${ }^{164}$.

Sobre la naturaleza social y política del hombre en Santo Tomás -y como lo expresa Lobato-, surge de la indigencia de la corporeidad del hombre. De igual manera, para este último las palabras de indigencia y miseria -además de referirse a la condición vulnerable y finita del cuerpo- significan la falta de una vida llevada a plenitud. De la naturaleza humana y su condición frágil, según el Aquinate, Lobato afirma:

\footnotetext{
${ }^{161}$ LoBATO, A. "La antropología de Santo Tomás de Aquino y las antropologías en nuestro tiempo”. Op. Cit., p. 196.

162 LOBATO, A. "El ser y quehacer político". Albertus Magnus (2009), núm. 2, p. 130.

163 Ibíd., p. 124.

${ }^{164}$ Ibíd., p. 126.
} 
El hombre es el único animal erecto, el único que tiene cosquillas, el único que ríe, el único que habla, el único racional y el único que tiene manos. Pero es al mismo tiempo el más indigente y el que se vale menos por sí solo para la vida. Por ello es normal que viva en sociedad y que sea más social que ningún otro ${ }^{165}$.

Además, uno de los aspectos fundamentales de la vida social que resalta Lobato en el pensamiento tomista es la comunicación. El hombre es de los seres más comunicativos de todos los animales. Las relaciones interpersonales se establecen por medio del lenguaje y la palabra, con la que se expresa lo humano, es decir, ideas, sensaciones y emociones. Sobre la importancia de la comunicación para la vida social -según el Aquinate-, señala Lobato:

Lo es también por su capacidad de comunicar con los demás por medio de la palabra. Los animales tienen una cierta capacidad de comunicación de sus necesidades de gozo o tristeza. El perro ladra, el caballo relincha. El hombre por medio del lenguaje, no sólo comunica con los demás su estado de ánimo, lo que es útil o inútil, justo o injusto. La comunidad ciudadana entre los hombres se hace mediante la palabra hablada, escrita, significada ${ }^{166}$.

Lobato resalta que santo Tomás era un hombre de la palabra y de la escritura. En el Aquinate conviene subrayar que su ejercicio de la palabra se hace explícita en la predicación por su vocación y carisma dominicano, pero acompañada del lema veritas: como dominico era un predicador de la verdad. Además, sus escritos abundantes y de diferentes índoles evidencian a un gran escritor. De manera que para Lobato:

Tomás de Aquino tuvo conciencia de la importancia cultural de la palabra y se esforzó por transmitirnos su pensamiento por escrito. No hay duda de que fue un gran escritor. La mayor parte de las palabras de Tomás que han llegado a nosotros han nacido como palabras escritas ${ }^{167}$.

El lenguaje en Tomás de Aquino es diálogo que origina encuentro. Sus escritos se construyeron en forma de diálogo que permitió a su vez el encuentro con otras culturas y formas de pensamiento. Sin embargo, su punto de partida y finalidad es la búsqueda y construcción de la verdad. Sobre el pensamiento del Aquinate y su elaboración siempre en diálogo afirmó Lobato:

\footnotetext{
${ }^{165}$ LoBATo, A. "La antropología de santo Tomás de Aquino y las antropologías en nuestro tiempo". Op. Cit., p. 144.

${ }_{166}$ LOBATO, A. "El ser y quehacer político". Op. Cit., p. 126.

${ }^{167}$ LOBATO, A. "El lenguaje y la palabra en Tomás de Aquino". Revista de filosofía. (1989), núm. 65, p. 137.
} 
La filosofía de Tomás de Aquino lleva en su entraña una exigencia de diálogo y encuentro, de enraizamiento en el pasado para poder proyectarse hacia delante, de acogida de toda aportación a la gran tarea comunitaria de conquista de la verdad, de memoria del pasado y anticipación del futuro $^{168}$.

\section{1. 5 La familia humana}

Para Tomás de Aquino la familia es la primera forma de vida social. Lobato resalta dos aspectos muy importante del hombre a la luz del pensamiento tomista: la singularidad y la sexualidad humana. La singularidad humana la aporta el cuerpo o materia como principio de individuación. Al mismo tiempo, la singularidad humana se presenta en la diferencia corporal sexual de varón o mujer. Según Lobato:

La existencia del ser humano es siempre singular, gracias a la materia corporal, que la realiza en concreto y hace posible la multiplicación de los seres dentro de la especie. Hay algo más en la doctrina tomista. El singular humano se verifica de modo dual gracias al cuerpo, es decir se diferencia en uno de los dos sexos, el singular es varón o es mujer ${ }^{169}$.

Para Abelardo el Aquinate tiene presente en su reflexión antropológica y de cara a la sexualidad el dato bíblico y los aportes de la cultura griega. El hombre es imagen y semejanza de Dios. La imagen esta en el alma creada directamente por Dios y en el cuerpo como una huella de la imagen, es decir, una imagen participada. Como lo señala Lobato:

Para Tomás el cuerpo no es solo un vestigio o una "huella" de Dios, es también imagen y semejanza de Dios. La semejanza se considera desde la forma. Pero la forma del cuerpo humano es el alma racional, en la cual se verifica la imagen de Dios. Y por eso en el cuerpo humano no se da solamente la semejanza del vestigio, sino también la semejanza de la imagen, en cuanto tiene $\operatorname{alma}^{170}$.

En la cultura griega se inspiró el Aquinate para hablar del hombre a nivel ontológico y biológico. En el primer nivel hizo suya una vez más la interpretación hilemórfica del hombre para hablar del ser concreto, es decir, cuerpo y alma que constituyen en su unidad la persona. Al decir de Lobato:

${ }^{168}$ LOBATO, A. "La filosofía de santo Tomás de Aquino y su estructura dialógica". Angelicum (1984), núm. 61, p. 82.

${ }^{169}$ LOBATO, A. "La antropología de santo Tomás de Aquino y las antropologías en nuestro tiempo". Op. Cit., p. 172.

${ }^{70}$ Ibíd., p. 173. 
Es una lectura del ser concreto que no admite acepción. Ahí entra de pleno la corporeidad de todos los seres humanos, en su esencia y en sus caracteres. Es ahí donde el cuerpo cobra toda su densidad ontológica y su dignidad al estar informado por el principio espiritual que es el alma $^{171}$.

En cuanto al segundo nivel, para Tomás de Aquino los dos sexos cooperan en la trasmisión de la vida humana. Según Lobato, "en ella se describe el papel de los dos sexos en orden a la generación de la especie humana"172. Pues si uno de los dos sexos falta ya no hay generación del ser humano. Con el desarrollo de la vida corporal y sexual en el pensamiento tomista, lo que el español resaltó fue la diferencia del hombre y la mujer, al mismo tiempo que destacó la importancia de la vida familiar y comunitaria.

Otro de los rasgos fundamentales de la relación interpersonal del varón y la mujer son las funciones perfectivas de la vida humana. De manera que -para Lobato- en santo Tomás son dos funciones complementarias que se dan en la vida de pareja: la primera es comunitaria y la segunda es familiar generativa. Así, el complemento se da por la mutua atracción de los sexos; además de la sociedad familiar, lugar de generación y educación de la prole. Según Lobato:

Para esta doble función la naturaleza ha dispuesto la unión del varón y la mujer, no sólo para un tiempo sino de modo permanente en la convivencia, en la cual los hijos pueden ser educados y llevados al pleno desarrollo, con la cooperación del hombre y la mujer ${ }^{173}$.

\section{1.6 El conocimiento del hombre}

Para Abelardo Lobato es fundamental el aporte de Tomás de Aquino a la promoción humana desde el desarrollo de las virtudes intelectuales, morales y técnicas o artísticas. EI Aquinate es formador del hombre, es decir, de las capacidades que ya tiene por naturaleza. Para Lobato: "las operaciones humanas se despliegan en tres órdenes diversos y concatenados. Los griegos lo habían clasificado como, theoria, praxis y poiesis" ${ }^{\text {"174. }}$.

En el italiano -según Lobato-, "en realidad hay que distinguir dos ámbitos de la acción humana, uno inmanente al sujeto, y otro transitivo" ${ }^{175}$. En el primero los actos acaecen en el interior del sujeto como principio y fin; en el segundo los actos parten del sujeto y

\footnotetext{
171 Idem.

172 Idem.

173 Idem., p. 179.

174 Ibíd., p. 201.

175 Idem.
} 
acaecen en la materia exterior, y quedan dispuestos conforme decide el hombre. Este aspecto es muy importante para Lobato porque de allí acontece lo que se llama cultura.

Lobato resaltó que en Tomás de Aquino hubo dos modos de acción inmanente: la manera como percibe la realidad y la proyección hacia ella. Esto sucede en virtud de las potencias o facultades de la razón y de la voluntad. De manera que por la primera potencia hay un movimiento que va de las cosas al alma. De ahí que conocer es abstraer y tiene su punto de partida en la sensibilidad externa y sigue al interior del hombre; por la segunda potencia se presenta un movimiento que va del alma a las cosas. Existe una relación entre conocimiento y lo que se desea, entre razón y voluntad, en cuanto se apetece sólo lo que se conoce. De modo que el hombre sale de sí y va hacia fuera en busca de lo que le conviene y le hace falta. Para Lobato:

De todo ello resultan los tres órdenes complementarios de acción y los tres tipos de hombre que conforman: orden del conocer, del apetecer, y del hacer. En el primero el hombre recibe los datos de las cosas, en los dos segundos ejercita su libertad. Del despliegue de los actos por medio de las potencias en la corporeidad resulta el homo sapiens, volens, faber ${ }^{176}$.

Para Lobato el alma humana, por su condición espiritual, es apertura ilimitada. Tomás se apropió la expresión aristotélica cuando afirma que el alma es en cierto modo todas las cosas (traducido al latín como anima quodammodo omnia). Pero el alma no obra por sí misma sino por medio de las potencias. En expresión lobatiana:

Los actos del hombre tienen su principio en la forma que es el alma. Pero no brotan de un modo inmediato, ni siquiera cuando son acciones peculiares de la parte espiritual del ser humano. La virtud fontal del alma se plurifica en sus potencias ${ }^{177}$.

La primera actividad del hombre es cognoscitiva. Del mismo modo lo manifiesta Tomás de Aquino en seguimiento de Aristóteles, cuando afirma que todo hombre por naturaleza desea conocer. No obstante, siguiendo el fundamento aristotélico-tomista del hilemorfismo, para Lobato:

El conocer humano se sitúa entre el conocer del animal, limitado a la esfera de lo sensible externo e individual, y el conocer de los espíritus, que tienen presencia de sí a sí mismos y penetran a la esencia de las cosas. Por ser una actividad que se sitúa entre esos dos extremos, necesita partir

\footnotetext{
176 Ibíd., p. 201.

177 Ibíd., p. 200.
} 
del orden externo, concreto y sensible, y puede culminar en el orden material, por el que capta la esencia $^{178}$.

Algunas actividades son propias del alma como conocer y querer, otras lo son del compuesto. Así mismo, en las del compuesto aparece un doble elemento: la potencia y el órgano. Sin embargo, en una y en otra el cuerpo es el lugar donde se origina el proceso de conocimiento. De manera que el conocimiento parte de lo sensible y se eleva a lo inteligible. Para Lobato, "todo conocer humano parte de la sensibilidad externa, y procede hacia el interior, en un proceso de selección y de cierta abstracción" ${ }^{\text {"179. }}$.

Entre los sentidos externos a los que Tomás de Aquino asignó más importancia fue al sentido de la vista y el oído. Pero el Aquinate adjudicó un significado más allá del objeto propio, como puntualizó Lobato: "Tomás da primacía al sentido de la vista, como sentido del mundo externo, y al oído como sentido de la palabra y la trasmisión de la cultura" ${ }^{180}$. Ahora bien, se produce otra actividad diferente a la cognitiva en su procedimiento porque parte del interior del hombre hacia el exterior. El Aquinate lo denomina apetito o movimiento hacia el bien. Éste se sitúa en relación con lo cognitivo. Según Lobato:

Para Tomás el conocer es un proceso que va de las cosas a la mente, y el apetito es el proceso contrario, que va de la mente a las cosas. El hombre sale de sí, va hacia fuera, porque busca lo que le conviene y le falta. Se apetece sólo lo que le falta ${ }^{181}$.

En Tomás de Aquino el apetito del hombre se desarrolla en tres esferas complementarias o integrativas que son -según Lobato-, "el genérico de la sensualidad, el específico de las pasiones, el trascendente de la voluntad y el acto libre" ${ }^{\text {182 }}$. El primero es el apetito natural que es común a todos los seres. La naturaleza les impulsa a su lugar natural. De esta manera, para Lobato, "el apetito natural no requiere conocimiento previo, tiende hacia el bien de modo determinado y bien seguro" ${ }^{183}$. El segundo es el apetito sensitivo, la sede de las pasiones. El alma se mueve hacia las cosas concretas conocidas por los sentidos y las desea en cuanto le producen un bien o las rechaza en cuanto le producen un mal. De manera que para el Aquinate, según Lobato:

\footnotetext{
178 Ibíd., p. 202.

179 Ibid., p. 203.

180 Ibíd., p. 204.

181 Ibíd., p. 209.

182 Ibíd., p. 211.

183 Ibíd., p. 213.
} 
El apetito sensitivo o sensualidad tomista es movimiento del sujeto hacia los bienes concretos, que el conocimiento ha descubierto en la esfera de lo sensible, en los entes reales, y los apetece aquí y ahora, como algo que le agrada, que le es útil o algún mal del cual huye porque es nocivo ${ }^{184}$.

Tomás de Aquino ha distinguido -a partir de la tradición aristotélica- las pasiones del alma en dos géneros, a saber: concupiscible (amor y odio, deseo y fuga, gozo y tristeza) e irascible (la esperanza y la desesperación, el temor y la audacia, y la ira, que no tiene contrario). La primera tiende a poseer lo que es proporcionado a su naturaleza, y la segunda tiende a superar lo que es contrario a la misma.

El tercero es el apetito racional. El objeto de la voluntad es el bien absoluto, si bien hay un dominio de la voluntad sobre el apetito natural y sensitivo. $Y$ sólo en este sentido -en cuanto tiene un dominio sobre ellas- se puede decir que son morales las pasiones humanas. Para Lobato, "la plena comprensión del apetito sensitivo se logra sólo desde la relación que tiene con el apetito superior, designado como voluntad o apetito racional, en la cual confluyen la naturaleza y la libertad" 185 .

La actividad transitiva que surge del sujeto pero que recae sobre la materia exterior se llama hacer, por el cual transforma su entorno. El hombre moldea la realidad según sus necesidades corporales y espirituales. Al decir de Lobato:

Tomás de Aquino ha entendido la actividad del homo faber como una respuesta a las necesidades de la corporeidad y un servicio a las capacidades del espíritu. Por ello ha comprendido el dinamismo factivo realizado en el trabajo, en el arte y en el cuidado y cultivo del cuerpo y de sus posibilidades humanas ${ }^{186}$.

El arte es una virtud intelectual que perfecciona el hacer del hombre. El hacer exterior está orientado por la razón. Desde esta perspectiva, para Tomás -como lo había afirmado Aristóteles-, las manos son el instrumento de los instrumentos. Para el Aquinate -según Lobato-, "la mano es el instrumento de su conexión con mundo y uno de los órganos de la razón"187.

\footnotetext{
184 Idem.

185 Ibíd., p. 216.

186 Ibíd., p. 219.

187 Idem.
} 


\section{1. 7 Finitud y fragilidad humana}

El límite de la vida humana es la muerte. Para Lobato el Aquinate era consciente de la condición-límite del hombre. Al decir de Lobato: "Tomás suele recurrir a lo humano, a la condición humana como lugar de necesidades y de miserias, debido a la corporeidad que impone límites a la realidad del hombre" ${ }^{188}$. No obstante, al Aquinate le interesó la comprensión de las miseria y sus defectos.

La situación de las necesidades en las que se encuentra el hombre, existe una ley natural que lo impulsa a satisfacer dichas necesidades. El hombre es por su condición corporal frágil y vulnerable, un ser de necesidades y deseos. Según Lobato:

Hay en todo hombre una lex naturalis que le empuja de modo constante y profundo a la búsqueda de todo lo que necesita para vivir como hombre. Buscar el alimento y dar satisfacción a las necesidades de la vida humana en todos sus niveles hace del hombre un ser menesteroso a lo largo de toda su existencia. Desde este punto de vista la vida del hombre es un tejido de necesidades y deseos ${ }^{189}$.

Según Lobato, el Aquinate explicó el estado actual o la situación del hombre desde la perspectiva teológica en tres momentos, a saber: el estado del hombre creado a imagen de Dios, el re-creado en Cristo, y el definitivo que es la participación de la vida divina. Así lo explicó Lobato:

La situación actual del hombre se puede ilustrar algo mejor desde tres puntos de referencia que van implicados en ella: uno el estado del hombre cuando fue creado por Dios, otro es el ejemplar perfecto que es Cristo, y un tercero es el estado definitivo de la vida eterna ${ }^{190}$.

Para Tomás de Aquino el hombre en el estado de inocencia o antes del pecado tenía en plenitud tres bienes constitutivos de su naturaleza por la que participaba de la bienaventuranza. Al decir de Lobato:

Tomás distingue tres clases de bienes de la naturaleza: esenciales, consecuentes, gratuitos. Una primera clase son los principios constitutivos de la naturaleza humana y las propiedades que de ellos se siguen, como las potencias del alma; otra clase de bienes es la inclinación a la virtud y al

\footnotetext{
188 Ibíd., p. 235.

189 Ibid., p. 239

190 Ibíd., p. 235.
} 
bien que emana de la misma naturaleza; y la tercera clase es la justicia original, un don especial dado al primer hombre para todos los hombres ${ }^{191}$.

No obstante, después del pecado la naturaleza del hombre ha quedado herida o debilitada para sus operaciones naturales de manera perfecta. Al mismo tiempo, el pecado ha deshumanizado al hombre en cuanto lo ha lesionado para obrar el bien o vivir virtuosamente. Según Lobato:

Tomás acoge la interpretación de Beda 'el Venerable' que describe las cuatro grandes heridas recibidas por el pecado original, las cuales han desvirtuado la naturaleza en su inclinación al bien, y han propiciado el desarrollo de la inclinación al mal. Esas heridas tocan los sujetos de la virtud: la razón, sede de la prudencia, la voluntad, asiento de la justicia, la potencia irascible, en la que reside la fortaleza, y la potencia concupiscible, sede de la templanza ${ }^{192}$.

El mayor de los males o enfermedades del hombre es la muerte. Así mismo, ella se constituye en el mayor obstáculo que el cuerpo impone al espíritu. Al mismo tiempo la muerte priva al hombre del mayor de los bienes que es la vida. Para Lobato:

Tomás de Aquino analiza el hecho universal de la muerte de todos los hombres y lo describe como privación de la vida, o separación de los elementos componentes del ser humano, justo lo contrario de la unión substancial del alma y del cuerpo ${ }^{193}$.

El problema para Tomás de Aquino no es la inmortalidad del alma, sino la inmortalidad del hombre. Sin embargo, para Lobato, "en la doctrina de Tomás sobre la muerte hay que poner de relieve tres afirmaciones, profundamente enlazadas entre sí: el hecho cierto de la muerte, la vida humana después de la muerte, y la resurrección de la carne”194.

La muerte del hombre es la separación del cuerpo y del alma. De esa manera la muerte es la privación de la vida. El hombre muere de verdad pero no muere del todo porque su forma subiste. El alma separada del cuerpo no muere por ser inmortal. Aunque el alma una vez separada del cuerpo hay una inclinación a unirse con él porque es su estado natural el estar unido al cuerpo y no separado. Así mismo, en la comprensión de la muerte tiene un papel fundamental para la teología cristiana el acontecimiento de la resurrección de Jesucristo, por la que el hombre participa de una nueva vida que será restablecida humana y teológicamente.

\footnotetext{
191 Ibíd., p. 247.

192 Ibíd., p. 248.

193 Ibíd., p. 251.

194 Idem.
} 


\section{1. 8 La persona humana}

La concepción de persona en el Aquinate es otro de las palabras fundamentales en el pensamiento lobatiano. Tomás de Aquino elabora su significado de persona de la herencia o legado histórico que antecede su desarrollo y evolución. De manera que para Lobato los vocablos que acompañan a la palabra persona son: la máscara, el sujeto, la dignidad.

La palabra persona significó en primer lugar máscara. Tomás es consciente de este primer significado que lo recoge de Boecio que hace alusión a los actores del teatro griego que representan o personifican a hombres y dioses en las tragedias y comedias. Al decir de Lobato:

Tomás conoce el origen de la palabra persona. La noticia le viene de Boecio, que la deriva de verbo latino personare. Los actores del teatro usaban máscaras para salir a la escena. La máscara tenía una doble función: la de presentar ante los demás un 'personaje' determinado, bien de los dioses o bien de los hombres, y el de proclamar en alta voz, resonar con potencia, servir de altavoz para el auditorio ${ }^{195}$.

Del significado de la persona hacia fuera como máscara paso a la interioridad de sujeto humano. De manera que Tomás descubre un segundo significado de la persona como sujeto. Según Lobato:

Para Tomás el sujeto humano se presenta como el lugar del infinito. El hombre es capaz de volver sobre sí mismo, y vive en una cierta presencia de sí a sí de modo atemático, que puede desplegar en sus actos a través de la conciencia y de la reflexión. La libertad brota de esta profundidad del sujeto humano ${ }^{196}$.

Finalmente, Tomás conoce un tercer aporte que los propone los dos misterios de la fe a saber: Dios es una esencia y tres personas; hay dos naturalezas en y una sola persona en Jesucristo. La persona es misterio que se devela a la luz de Dios y se concibe con un ser digno. Para Lobato:

El misterio de las personas divinas abre la puerta a la teología de la persona. La persona cobra un nuevo e inesperado significado, da el salto a lo más digno y noble, y abraza en un horizonte a Dios, los espíritus y el hombre ${ }^{197}$.

\footnotetext{
195 Lobato, A. "La persona en Santo Tomás de Aquino". Ius Públicum. (2001), núm. 6, p. 15

196 Ibíd., p. 18

197 Idem.
} 
La novedad tomista radica en la definición de la persona desde el ser y queda plasmado en la definición sencilla y densa: persona significa la realidad más perfecta, un ser concreto de naturaleza racional. Desde esta perspectiva las notas que caracterizan a la persona desde la perspectiva tomista son: totalidad, subsistencia y espiritualidad. De tal manera que la persona es un sujeto integral, subsistente y de naturaleza espiritual.

De manera que la persona en primer lugar es totalidad, integridad, singular y existente: "El ser personal queda excluido donde hay sólo partes, entidades abstractas, donde no hay autonomía e independencia" ${ }^{198}$; en segundo lugar la persona es subsistente $e$ incomunicable: "La subsistencia es el fundamento del singular. Indica el modo de ser, la duración en el ser, la exigencia de independencia y autonomía” ${ }^{199}$; en tercer lugar, la persona implica naturaleza espiritual: "Se requiere en la persona un modo de ser noble, digno, excelso: la condición espiritual”200.

\section{1.9 La dignidad del hombre}

Para Lobato el tema de la dignidad humana es desarrollado por Tomás de Aquino al lado del tema de la persona. De manera que Lobato hace eco de dos afirmaciones del Aquinate en las que hace alusión a la correlación de estas dos palabras: "La persona omnium naturarum dignissima, perfectissima in tota natura" ${ }^{201}$.

Una de las constantes de la dignidad humana es la de atribuirle una propiedad de excelencia. Según Lobato: "Para Tomás de Aquino la dignidad no puede reducirse a un mero accidente, no puede ser sólo una conquista mediante o consecuencias del ejercicio de algunas relaciones" ${ }^{202}$. Para Abelardo hay dos modos de acceso a la dignidad y al mismo tiempo son contrarios en la manera de concebirla. De modo que para Lobato,

Uno la concibe como la cualidad de un sujeto humano; el otro la percibe como el sujeto mismo. En el primer momento la dignidad brota de un modo de ser; en el segundo la dignidad da origen al ser mismo. Allí tenía carácter de accidente, aquí ha ocupado el puesto de la sustancia, del fin. El primero modo la adscribe al ser, el segundo la hace origen del ser. El primer modo implica una

\footnotetext{
${ }^{198}$ Ibíd., p. 24.

199 Ibíd., p. 25.

200 Ibíd., p. 26.

201 LOBATO, A. "La dignidad del hombre y los derechos humanos". Op. Cit., p. 82.

202 LobAto, A. "La dignidad del hombre en santo Tomás de Aquino". Carthaginensia. Vol. 6 (1990), núm. 9, p. 146.
} 
metafísica, que da origen a una ética, el segundo es más bien una dimensión ética que excluye toda metafísica ${ }^{203}$.

Entonces a Santo Tomás se le puede ubicar en medio de las dos concepciones de la dignidad; no obstante, seguirá de algún modo en la línea de la primera concepción. Es así que para Abelardo la dignidad del hombre en Tomás de Aquino hay que comprenderla desde el ser del hombre, es decir, la vía metafísica. Por lo tanto, según Lobato para el Aquinate:

No hay otra vía para fundar la dignidad que no incluya la vía metafísica. Esa es la vía del ser. El ser del hombre es personal. De la persona le viene al hombre la dignidad radical. De esa raíz originaria, común a todo hombre, proceden todas las otras perspectivas de la dignidad humana. Sin ella no tiene consistencia ${ }^{204}$.

Sin embargo, Abelardo tiene presente que Tomás de Aquino como teólogo trata más de la dignidad de Dios y de Cristo que del hombre. De ahí que cuando el Aquinate se refiere a la dignidad del hombre lo hace con referencia a Dios y de su creatura sólo por participación. De modo que para Lobato, "por ser teólogo Tomás de Aquino ha tratado más de la dignidad de Dios y de su Hijo Jesucristo que de la dignidad del hombre, quien sólo participa de esa fontal dignidad" ${ }^{\prime 205}$.

En definitiva, la incidencia que el pensamiento tomista ha tenido en la obra de Lobato es fundamental para la construcción de su pensamiento. Es así que va a crear un horizonte conceptual de pensamiento propio que se designa lobatiano. Esto ha sido posible porque Abelardo Lobato ha seguido la enseñanza o doctrina de Santo Tomás y se ha servido de ella para iluminar en un diálogo fructífero los problemas de la cultura actual, abriendo nuevos horizontes de futuro para la humanidad.

\section{2 Horizonte conceptual del pensamiento lobatiano}

Abelardo Lobato es creador de un horizonte conceptual propio de su pensamiento. Esto ha sido posible y es fruto del diálogo que establece entre el saber tomista y la cultura actual. De ahí que es fundamental el desarrollo los conceptos propios del pensamiento lobatiano. Esto permite conocer los fundamentos, lo propio y central de su doctrina.

\footnotetext{
203 Ibíd., p. 143.

${ }^{204}$ Ibíd., p. 146.

${ }^{205}$ LOBATO, A. "La dignidad del hombre en Santo Tomás de Aquino". Op. Cit., p. 147.
} 


\section{2. 1 Las vías de acceso al hombre en la actualidad}

Para Lobato la amnesia es lo que caracteriza la cultura actual. Sobre todo hay un olvido de lo trascendental y que ha venido como consecuencia de la metafísica, en efecto: "Hay un olvido de Dios, que ha venido como consecuencia del olvido del ser"206. Además Lobato subraya que hay que señalar a éstos dos olvidos radicales, "el olvido del alma, el olvido de la inteligencia y el olvido de la virtud"207.

Lobato, al momento de adentrarse a tratar el tema del hombre se encuentra, como el Aquinate en su momento, con diversos caminos o vías de acceso al hombre en la modernidad. De manera que para el dominico español en la búsqueda y comprensión acerca de la verdad sobre el hombre en la actualidad encuentra que hay una situación antropológica que resulta siendo paradójica y la describe de la siguiente manera: "Nunca supimos tantas cosas acerca del hombre. $Y$ al mismo tiempo el hombre de hoy se siente incapaz de decir una palabra definitiva sobre el ser del hombre"208. Esto ha dado origen a las pluriformes e inconexas antropologías con las que nos encontramos en la actualidad. Ante esta situación considera Lobato que es necesaria una reflexión clarificadora, ${ }^{209}$ es decir, que nos permita conocer la antropología actual.

Todo discurso antropológico busca la verdad acerca del hombre. Para Lobato los primeros discursos antropológicos tienen su origen en la cultura griega que inicia con Aristóteles en la obra De Anima. Posteriormente, su desarrollo se presenta en la cultura cristiana con los tratados De Homini a partir de Nemesio de Emesa. $Y$ desde el fenómeno histórico del lluminismo se designa con el hombre de Antropología ${ }^{210}$. Mientras tanto, la situación antropológica actual se caracteriza -al decir de Lobato-, porque vivimos las consecuencias del llamado giro antropológico ${ }^{211}$.

Para Lobato el giro antropológico lo inició resueltamente L. Feuerbach. Aunque el significado de la expresión se fue enriqueciendo y ha variado con el tiempo, sin embargo

${ }^{206}$ LoBATO, A. Dignidad y aventura humana. Op. Cit., p. 14.

207 Idem.

${ }^{208}$ LOBATO, A. "La antropología de santo Tomás de Aquino y las antropologías en nuestro tiempo". Op. Cit., p. 72.

${ }^{209}$ Cf. LOBATo A. "Antropología y metantropología: Los caminos actuales de acceso al hombre". En: Antropologia e Cristologia ieri e oggi. Atti del Convegno di Studio della SITA. Roma: Pontificia Universitá S. Tommaso D'Aquino, 1987, p. 6.

210 LobATo, A. "La antropología de santo Tomás de Aquino y las antropologías en nuestro tiempo". Op. Cit., p. 72.

7.

Cf. LoBAto A. "Antropología y metantropología. Los caminos actuales de acceso al hombre”. Op. Cit., p. 
para el filósofo alemán, "era la proyección de su horizonte intelectual"212. Es decir que si en primer lugar su pensar se fundamentaba en Dios, Creador del hombre a su imagen, posteriormente llega a considerar que es el hombre quien crea a los dioses a su medida. No obstante, con el tiempo el significado de giro antropológico ni implica tácitamente la exclusión de Dios o del mundo, sino que el hombre necesita partir desde sí mismo para poder interesarse por lo demás. En este caso dirá Lobato: "Para que algo tenga actualidad en nuestra cultura es preciso que implique lo humano, que diga referencia al hombre" ${ }^{213}$. Éste es el punto donde ha anclado el giro antropológico con sus consecuencias.

Aunque para Lobato la compresión del hombre ha tenido dos etapas o momentos que le han precedido, que se distinguen e inciden en nuestra situación cultural, a saber: el pensamiento clásico y el pensamiento kantiano. De manera que, "una es la etapa del pensamiento clásico, connatural al hombre, otra es la etapa que se inicia con el pensamiento kantiano, expresión del iluminismo que ha imperado en la modernidad”214. En efecto, la comprensión del hombre en el pensamiento clásico se realiza en el horizonte de la totalidad del ser, acentuando la diferencia sin perder la unidad. Como lo explica Lobato:

Por una cierta inclinación connatural a la inteligencia, al intentar una autocomprensión el hombre es propenso a verse como un ser entre los demás, en un horizonte de totalidad, en comunión con el resto de los entes, percibido en su singularidad por algunos rasgos diferenciales ${ }^{215}$.

Así mismo, en el modo clásico de construir una antropología aparecen dos notas o expresiones que la caracterizan, entre las que oscilan, en primer lugar: "Los pensadores buscan al hombre en el seno de la totalidad a través de las diferencias" ${ }^{216}$; en segundo lugar: "Se percibía mejor a sí mismo desde el proceso descendente de la participación" La primera es propia de la cultura griega, para la cual la imagen de hombre es la de microcosmos y la segunda de la cultura judeo-cristiana, para quien el hombre es imagen de Dios. De modo que el hombre al mismo tiempo que un ser en el mundo es una creatura de Dios. Al decir de Lobato:

\footnotetext{
${ }^{212}$ LoBAto, A. "La antropología de santo Tomás de Aquino y las antropologías en nuestro tiempo". Op. Cit., p. 73.

213 Ibíd., p 74.

214 Idem.

215 Ibíd., p. 75.

216 Idem.

${ }^{217}$ Idem.
} 
En definitiva el pensamiento clásico, que se prolonga desde el pensar griego hasta el desarrollo de la filosofía cristiana, cuyo exponente más completo es Tomás de Aquino, trata de la comprensión del hombre desde una precomprensión del ser, de la totalidad de los entes, dado que su pensar es siempre pensar el ser y los entes ${ }^{218}$.

Además de esta comprensión del hombre en el pensamiento clásico se originan diversos discursos antropológicos. Lobato señala los siguientes: animal dotado de palabra, ser habitado por el espíritu, imagen y semejanza de Dios, microcosmos, animal racional, ser social y político ${ }^{219}$. Aunque sin perder todos estos discursos acerca del hombre su fundamento y unidad.

Para Lobato, "en el seno de esa poderosa tradición surgió la antropología kantiana"220. Lo decisivo en el pensamiento de Kant ha sido la suplantación del campo del objeto por el sujeto, es decir, el pensamiento por el objeto a pensar. En efecto, el hombre ilustrado es aquel que sigue los criterios que ilumina la propia razón. Para Abelardo: "Hay dos palabras que caracterizan el pensamiento kantiano: la crítica y la antropología"221. La crítica es un rechazo a la metafísica y a la comprensión del hombre en la totalidad del ser y queda una preferencia por la subjetividad y por el hombre como fundamento y horizonte de comprensión. Sobre la crítica señala Lobato:

Por un lado la crítica designa el análisis de las condiciones de posibilidad de todo pensar humano, es como irrupción del sujeto que impone límites a la misma realidad. Por la crítica el sujeto descubre sus posibilidades, el rol del yo pienso pone de manifiesto que el pensar es más bien proyectar que recibir, que lo conocido en los objetos es lo puesto en ellos por el sujeto, que el sujeto está en la raíz de todo filosofar. Por la crítica se descubren los límites de la razón en su anhelo natural de ir a las cosas. Con ella se deshace esta pretensión ingenua de alcanzar las cosas en sí mismas a través del pensamiento ${ }^{222}$.

Por lo tanto, para Kant el nuevo camino de la filosofía es la antropología, pues de ella depende el saber, el hacer y el esperar del hombre. De manera que para Kant el hombre es punto de partida y de llegada de todos los problemas. Más aún como lo hace saber

\footnotetext{
218 Ibíd., 76.

${ }^{219}$ Cf. LOBATO A. "Antropología y metantropología. Los caminos actuales de acceso al hombre". Op. Cit., p. $9-10$.

220 Ibíd., p. 11

${ }^{221}$ Idem.

222 LOBATO, A. "La antropología de santo Tomás de Aquino y las antropologías en nuestro tiempo". Op. Cit., p. 77.
} 
Lobato: "El hombre suplanta el puesto que antes ocupaba el ser y había sido reservado en la historia a Dios o a la physis" ${ }^{223}$. Sobre la antropología señala Lobato:

Y la antropología tiene que enfrentarse primero con el hombre, con la pregunta por el hombre, como la más radical, y luego ser capaz de prolongar esa pregunta en las dos grandes direcciones, la de la naturaleza y la de la libertad. Kant proyecto la antropología como la disciplina peculiar de la filosofía, y trato de desarrollar en tres partes integrantes, una fundamental, que responde a la pregunta por el hombre; otra física, que analiza lo que la naturaleza hace con el hombre, y otra pragmática, que se ocupa de lo que el hombre hace con su libertad ${ }^{224}$.

No obstante, para Lobato el proyecto antropológico kantiano no se realizó o es inacabado. Como lo indica este estudioso español:

De hecho el proyecto kantiano de inversión de marcha realizó mejor la parte crítica que la antropológica. Le fue más fácil demoler que construir. Es cierto que se ocupó de la antropología, pero sólo de la que llamo pragmática, en la cual apenas encontramos un manojo de reflexiones que resisten un análisis serio y puedan decirse frutos del genio. La antropología quedó como "deseo natural", como él decía de la metafísica ${ }^{225}$.

Algo semejante ocurre con el pensador Max Scheler, para quien los problemas de la filosofía se reducen a la pegunta: ¿qué es el hombre? Aunque en sus ensayos anticipaba la elaboración de una gran antropología que daría respuesta definitiva a los problemas sobre hombre, no lo logró: "La muerte le salió al paso antes de llevar a cabo su trabajo y sólo nos quedan las primicias anticipadoras de su esquema en el libro de 1928, fruto de algunas conferencias: el puesto del hombre en el cosmos"226. De manera que Scheler proyectaba una antropología como cuarta vía que englobara las que aún persistían en su momento, es decir, la judeo-cristiana, la griega y la darwiniana. Sin embargo, se pregunta Lobato si el proyecto antropológico scheleriano era realizable, a lo que responde:

Pero Scheler estaba condenado a no poder llevar a cabo su obra porque no tenía bases para fundarla: no tenía adecuada comprensión de la función de la inteligencia en la penetración de lo real; dejaba de lado al ser, diluía el espíritu del hombre en una fusión con el espíritu absoluto,

\footnotetext{
${ }^{223}$ Idem., p. 78.

${ }^{224}$ LOBATO A. "Antropología y metantropología. Los caminos actuales de acceso al hombre". Op. Cit., p. 12.

${ }^{225}$ Ibíd., p. 12.

${ }^{226}$ LobATo, A. "La antropología de Santo Tomás de Aquino y las antropologías en nuestro tiempo". Op. Cit., p. 78.
} 
como si fuera el lugar donde el Absoluto se realiza, ya que de suyo se caracteriza por la impotencia y la debilidad ${ }^{227}$.

Ahora bien, el proyecto antropológico de Scheler ha tenido efectos contrarios a los propuestos. Es decir que el problema de nuestra situación antropológica actual es que en lugar de antropología tenemos antropologías, fenómeno que llama Lobato el laberinto de las antropologías, porque estamos inmersos en un pluralismo. Por lo cual, para éste es necesario una comprensión que permita clasificarlas para conocer las características y diferencias de cada una de ellas. En este orden de ideas, para lograr la comprensión de las antropologías actuales, sus diferencias e integrarlas, el método adecuado sigue siendo para Lobato las dos vías clásicas de la escala cognoscitiva, es decir, "del singular al universal, y del universal al singular, del hombre existente al hombre, del concepto del hombre, al hombre de carne y hueso"228.

Lobato acepta una primera clasificación y diferenciación de la antropología en nuestro tiempo en tres campos, a saber: el científico, el filosófico y el teológico ${ }^{229}$. Así las cosas, considera que hay dos momentos por las que se han distinguido: el primero por su relación mutua en estos tres campos del saber; el segundo por su independencia y separación. En un primer momento, al decir de Lobato:

La teología era sabiduría de las cosas de Dios y tenía subordinadas a todas las ciencias humanas. La filosofía primera era sabiduría y sometía todo el saber de las ciencias. La ciencia, por tanto, resultaba subordinada a los saberes superiores y su campo era el de las conclusiones en torno al objeto propio $^{230}$.

A decir verdad, para Abelardo esta relación de los saberes ha cambiado, de igual manera que ha cambiado su relación, la superioridad y subordinación se ha invertido. Ya no sólo son autónomas sino separadas e independientes. Además, la primacía la ocupa en el momento actual la ciencia y sobre ella se han construido la antropología filosófica y teológica. Así mismo, estos últimos saberes sienten la necesidad de dialogar con la ciencia y de admitir sus resultados, mientras que ésta no presta interés por las teorías de los filósofos y de los teólogos. Como advierte Lobato:

${ }^{227}$ LOBATO A. "Antropología y metantropología. Los caminos actuales de acceso al hombre". Op. Cit., p. 13.

${ }^{228}$ Ibíd., p. 17

229 Idem.

${ }^{230}$ Idem. 
Ni la filosofía ejerce una función ancilar, ni las ciencias admiten pacíficamente un saber superior que le indique sus competencias. En el mejor de los casos los distintos saberes se consideran autónomos. $\mathrm{Y}$ en la mayoría de las situaciones hoy tiene la ciencia la pretensión de imponer su criterio y de ejercer sobre los demás saberes un dominio despótico, una primacía, apoyada en la proximidad a lo real y en la fuerza de los datos que verifique en su propio campo ${ }^{231}$.

La ciencia se ha extendido y concretado en la técnica. Al mismo tiempo su etapa más avanzada está expuesta en la cibernética e informática. De igual forma se ha extendido a la comprensión del hombre. De modo que en su análisis antropológico ha dado origen a nuevas ramas que se llaman las ciencias humanas. Entre los senderos que ha abierto la ciencia en la búsqueda de lo humano y del hombre, Lobato distingue los siguientes: la física, la biología, las ciencias del hombre y la cibernética ${ }^{232}$.

Desde luego, la física ha contribuido a la comprensión del significado del hombre en el universo, y además a interrogarse sobre la relación del mundo con él. De igual manera a situarse el hombre en el cosmos. Efectivamente, para Lobato: "Asistimos en nuestros días a una apasionante discusión en torno al llamado principio antrópico del hombre"233. Es así que el intento de los físicos teóricos, desde A. Einstein a W. Heisenberg, ha buscado exponer la visión total del universo y el puesto que el hombre ocupa en el cosmos. Además de los físicos anteriormente mencionados, según Lobato tenemos que señalar en esta misma línea al físico teórico Stephen Hawking. Sin embargo, para Lobato la teoría que más impacto cultural ha causado en la comprensión del hombre ha sido la de P. Teilhard de Chardin al integrar al máximo al hombre en el universo.

Por otra parte, "la biología ocupa en parte el puesto de la antigua physis"234. Aunque la biología humana con frecuencia se convierte en antropología. De esta manera en la comprensión del hombre el biólogo J. Monod considera que el hombre es un ser más que integra el reino de la vida que funciona como lo demás y es fruto en parte del azar y en parte de la necesidad ${ }^{235}$, como lo sustenta en su escrito El azar y la necesidad. Más aún, según Lobato, para los biólogos la principal barrera que se opone a la comprensión del

\footnotetext{
${ }^{231}$ LoBATO, A. “La antropología de Santo Tomás de Aquino y las antropologías en nuestro tiempo”. Op. Cit., p. 17.

${ }^{232}$ Cf. LobAto A. “Antropología y metantropología. Los caminos actuales de acceso al hombre”. Op. Cit.,19

${ }^{233}$ Idem.

${ }^{234}$ LoBATo, A. "La antropología de Santo Tomás de Aquino y las antropologías en nuestro tiempo". Op. Cit., p. 82.

${ }^{235}$ Cf. Idem. Op. Cit., p. 83.
} 
hombre es el origen de la vida y el funcionamiento del cerebro, pues todo lo demás lo reducen a la materia viva explicada desde el ADN, responsable de contener toda la información genética de un individuo o ser vivo ${ }^{236}$.

Así mismo, para Lobato desde la biología se ha buscado la diferencia y la relación entre el hombre y el animal. Para unos como Scheler la diferencia estriba en la manera de relacionarse el hombre con el mundo, mientras el animal está determinado por el mundo que lo rodea, el hombre lo domina y construye; para otros como A. Gehlen existe sólo una diferencia de grado y no de naturaleza; y hay quienes buscando una postura media -como E. Morin- considera que el hombre proviene del animal, pero se diferencia porque ha desarrollado la cultura ${ }^{237}$. Finalmente, se pone el acento en la diferencia que presenta el hombre: su pensamiento como lo observó Descartes.

De igual manera, los biólogos han realizado el análisis para la comprensión del hombre a partir de tres binomios de palabras: cuerpo-alma, cuerpo-mente, cerebro-pensamiento. Para Lobato persiste un fuerte rechazo para hablar del alma, a tal punto que ha quedado sustituida por la mente. De modo que se han desarrollado dos tesis: una monista y otra dualista. Para el monismo reduccionista el cerebro es la única realidad humana en que todo tiene su explicación. En ella se presentan dos tipos de explicación que son: monismo fisicalista y el materialista emergentista. Para el primero todo lo humano se puede explicar desde la mecánica, cuyos defensores son H. Feigl, D. M. Armstrong, M. A. Turing, y D. M. Mackay. Mientras que el segundo defiende que el hombre es superior a los animales porque es libre y creativo, postura típica de M. Bunge.

A su vez, la tesis dualista establece las diferencias entre mente y cerebro. De manera que el cerebro sería material y la mente no lo es. Entre sus partidarios está K. Popper, quien defiende el dualismo emergentista, según el cual la mente es una inmaterialidad producida por la misma evolución. Mientras J. C. Eccles sostiene un dualismo neo-cartesiano al tratar de mantener la espiritualidad y admite la presencia del espíritu. Mientras que J. A. Fador sostiene un dualismo funcionalista que se hace patente en la Inteligencia Artificial (IA).

\footnotetext{
${ }^{236}$ Cf. LobATo A. "Antropología y metantropología. Los caminos actuales de acceso al hombre". Op. Cit., p. 20.

${ }^{237}$ Cf. LobATo, A. "La antropología de Santo Tomás de Aquino y las antropologías en nuestro tiempo". Op. Cit., p. 83.
} 
Para Lobato, "las ciencias del hombre han sido punto de partida de numerosas antropologías de nuestro tiempo" ${ }^{238}$. Las ciencias humanas son la psicología y la sociología. La psicología ha tratado de develar lo profundo o interior del hombre, aunque como ciencia -según Lobato- sea sin alma. Freud fue el pionero en querer descubrir el interior del hombre y halló el inconsciente; desde entonces su aportación se hizo fundamental en la construcción del discurso antropológico.

Por otra parte, la sociología se indaga por la relación del hombre con otros hombres. Así mismo, se detiene en la observación del comportamiento del hombre con los demás. La sociología crítica o de la escuela Frankfurt y la sociología analítica han abierto nuevos horizontes en la comprensión del hombre, con sus investigaciones sobre el fenómeno social en la antropología actual. Además la sociología realiza un giro copernicano, al decir de Lobato, "de una interpretación del hombre como ser singular, personal, aislado, se ha pasado a una comprensión de la convivencia humana, del comportamiento del hombre con el hombre"239.

En cuanto a la cibernética -al decir de nuestro autor-, "es la más moderna de las ciencias con proyección en la antropología"240. En ella se relaciona la ciencia y la técnica al modo humano. Es decir, las máquinas se construyen a imitación de las funciones corpóreas humanas. Este nuevo saber cada año evoluciona con nuevos inventos al servicio del hombre, al mismo tiempo que busca atender y satisfacer las necesidad en general del hombre como a crear otras.

En el campo del saber filosófico, para Lobato la filosofía actual ha tratado de hacer antropología. Esto se debe a que ha perdido el ser o la trascendencia que guiaba el horizonte filosófico. Los filósofos se han reducido al campo de la subjetividad y ha pasado del ser del hombre al estar. "En este clima han llamado la atención de los pensadores los fenómenos existenciales, la condición, la situación, las actividades" ${ }^{241}$. En consecuencia, ha surgido una antropología filosófica con un sentido de tragedia en el que impera la angustia y la miseria.

\footnotetext{
${ }^{238}$ LOBATO A. "Antropología y metantropología. Los caminos actuales de acceso al hombre". Op. Cit., p. 22. $\mathrm{p}_{240} 85$.

${ }^{241}$ lbíd., p. 87.
} 
En consonancia, para Lobato: "El panorama de la filosofía antropológica actual es más difícil de abarcar que el científico, porque cada filósofo elabora su propia antropología"242. No obstante, él llevó a cabo una aproximación a la filosofía antropológica desde Heidegger y Zubiri. Al primero lo consideró prolongador de la obra inconclusa de Scheler; el segundo trató de enlazar la escolástica con la cultura actual. Y entre los dos filósofos ubicó una serie de antropólogos en tres grupos: "el primer grupo pone de relieve la finitud del sujeto humano, el segundo destaca los fenómenos y actividades del hombre desde las cuales descubre las estructuras que los apoyan, y el tercero subraya la dimensión cultural típica del hombre" 243 .

Heidegger -además de mostrarse preocupado por una comprensión del hombre- orientó su pensamiento hacia el ser y no hacia el ente. Para Lobato: "Heidegger analizó la finitud, se circunscribió al horizonte de la temporalidad, y desarrolló su pensamiento como un ensayo sobre el ser del hombre, que es un ser ahí, un Dasein"244. Puesto que el hombre no puede ser fundamento de toda verdad, como lo pretendía Kant, necesita un fundamento que es el ser, que le excede y le funda. De manera que el hombre es el lugar donde el ser se manifiesta.

Según Lobato, la obra Ser y tiempo de Heidegger es una reflexión sobre el hombre y sus estructuras en cuanto ser finito. Por lo que la categoría finitud es central en su pensamiento. De manera que el ser humano es un-ser-en-el-mundo. En esta perspectiva como lo señala Lobato-, "el hombre en definitiva, es una existencia en el mundo, situada en el horizonte del cielo y de la tierra, de los dioses y los hombres"245. De aquí surgen todas las antropologías existencialistas, pues tomaron la existencia como punto de partida y centro de todo su pensar en torno al hombre.

Entre los principales mentores del existencialismo se encuentra J. P. Sartre. Para Abelardo, la obra El ser y la nada es un ensayo de antropología y, por ende, su pensamiento es un intento de aproximación al hombre. Y la forma de hacerlo es buscando un espacio para hablar del ser-para-sí y de la libertad. Finalmente, el hombre viene siendo pura libertad pero que se extingue en sí misma sin trascenderse. "Por ello el hombre es una pasión inútil, un ser de más, un absurdo, el único ser en el que la existencia precede la

245 LoвAto A. "Antropología y metantropología. Los caminos actuales de acceso al hombre". Op. Cit., p. 27. 
esencia"246. El existencialismo es para Lobato una aproximación al ser del hombre en la realidad cotidiana y singular. A su vez, un fenómeno efímero o pasajero que no dejo huella durable.

Posteriormente al existencialismo viene el estructuralismo. Se trata de ver más de cerca la finitud del sujeto humano. Entre sus representantes está M. Foucault, quien, según Lobato, se atreve a afirmar que, "el hombre es una invención reciente, llamada a desaparecer muy pronto, porque en realidad ni hay sujeto, no se da una historia humana, ni hay espacio para las ciencias del hombre distintas de las ciencias de la Naturaleza"247. En efecto, no hay más que estructuras. Su discurso antropológico es desarrollado por Lévy-Strauss y L. Althuser, quienes llegaron al mismo resultado o conclusiones.

El segundo grupo de filósofos "por el contrario, se declaran por el hombre, son defensores de lo humano"248. En su mayoría proceden del campo de la fenomenología y tienen, por lo tanto, alguna relación con Husserl. De igual manera este grupo atento a los fenómenos humanos intenta develar lo que es el hombre a través de ellos. Entre los fenómenos más estudiados están el lenguaje, la historicidad y la mortalidad.

Los griegos habían definido al hombre como un animal parlante. Con la fenomenología el lenguaje se convierte como el lugar de la revelación del hombre y del ser. "Ahora el lenguaje es sustituto del ser y del pensar". Desde la perspectiva filosófica, Wittgenstein es el iniciador, lo sigue Fichte y desde la perspectiva religiosa Buber y Ebner. En cuanto a la historicidad, es otro de los fenómenos antropológicos, que considera al hombre como un ser histórico. "El compromiso de la libertad humana frente a Dios, frente a los hombres y frente a sí mismo, el modo de asumirla y proyectarla en las diversas circunstancias hace la historia"249. Para Ortega y Gasset el hombre es historia. No obstante, desde Kierkegaard la historicidad y la libertad se hacen subjetivas.

Por otra parte, en el pensamiento antropológico actual la condición mortal del hombre se constituye en otro de los fenómenos de reflexión. La novedad estriba en la comprensión del sentido de la muerte. De aquí surge la concepción del hombre como ser personal. "El

${ }^{246}$ LOBATO, A. "La antropología de santo Tomás de Aquino y las antropologías en nuestro tiempo". Op. Cit.,

${ }_{247} 89$.

248 LOBATO A. "Antropología y metantropología. Los caminos actuales de acceso al hombre". Op. Cit., p. 28.

${ }^{249}$ LobAto, A. "La antropología de santo Tomás de Aquino y las antropologías en nuestro tiempo". Op. Cit., p. 91. 
recurso a la persona era una sólida defensa del hombre. Se trataba de una oposición al idealismo, a las ideologías que ignoraron el valor del singular"250. Maritain -en su defensa por la persona- la opone al individuo; Mounier, quien la personifica, descubre las relaciones radicales de la persona, su vocación, comunión y compromiso; Levinas es quien desarrolló esta tendencia filosófica en su dimensión ética y el rostro humano.

Asimismo, la cultura es otro lugar antropológico. "La cultura es englobante de buena parte de los fenómenos humanos: del lenguaje, las costumbres, las técnicas, los valores éticos y religiosos" ${ }^{251}$. El hombre no sólo produce la cultura sino que es producto de ella. Entre los mejores exponentes está Bloch.

Finalmente, Lobato cierra el panorama filosófico con Zubiri, además de García Bacca y Julián Marías como filósofos actuales españoles que han reflexionado acerca del hombre. Zubiri plasmó su reflexión acerca de la realidad y su prelación sobre la esencia. Su obra Sobre el hombre es una respuesta a los interrogantes de la antropología actual, desde los supuestos de la filosofía realista. De manera que: "analiza con rigor las estructuras del hombre, como ser personal con sus dimensiones, individual, social, e histórica, moral y religiosa" ${ }^{252}$.

Como culmen, en el ámbito del saber teológico la antropología teológica ha conocido el giro antropológico. Para Lobato esto ha sucedido tanto en la teología católica como protestante. Entre sus representantes en el ámbito protestante descuellan K. Barth, P. Tillich, R. Bultmann, W. Pannenberg, J. Moltmann, J. A. Robinson y D. Bonhoeffer. En el ámbito católico sobresalen R. Guardini, J. B. Metz, H. Küng, H. R. Schlette, H. Mühlen, E. Schillebeeckx, K. Rahner, Urs Von Balthasar, entre otros.

Rahner es considerado como uno de los defensores del giro antropológico. Para lograr su cometido ha interpretado el pensamiento del Aquinate desde el método trascendental kantiano. "Rahner ha afirmado más de una vez y tratado de demostrarlo que toda teología es antropología y viceversa" ${ }^{253}$. El teólogo Urs Von Balthasar desarrolla su antropología teológica desde el recurso de la analogía antis y la belleza como trascendental. Para este teólogo, según Lobato: "Es preciso partir de la prioridad de la analogia fidei, por la cual el

\footnotetext{
250 Idem.

251 lbid., p. 92.

${ }^{252}$ Idem.

${ }^{253}$ LOBATO A. "Antropología y metantropología. Los caminos actuales de acceso al hombre”. Op. Cit., p. 33.
} 
hombre es capaz de responder a la llamada de Dios. Esta analogía funda la analogia entis, en la cual se expresa la consistencia de la creatura y su autonomía en relación con el plan de Dios" ${ }^{254}$. De manera que en la encarnación de Cristo se concreta la analogia entis. De allí recorre la historia de la salvación guiado por la belleza que Dios ha derramado en su obra.

Por otra parte, el teólogo protestante Pannenberg elabora su antropología teológica desde la autotrascendencia. "La referencia a Dios es un constitutivo de la naturaleza humana. Este teólogo está convencido de que todo en el hombre conduce a Dios, a la participación del ser en Dios" ${ }^{\prime 25}$. No obstante, la naturaleza humana se desarrolló en diversas etapas de la historia hasta llegar a su perfección con la gracia de Dios.

\section{3 La antropovisión en el pensamiento lobatiano}

Una vez que Abelardo ha descrito y presentado un panorama general del pensamiento contemporáneo acerca del hombre, elabora su propio discurso antropológico. Aunque valora los aportes que se han hecho en torno a la pregunta por el hombre, sin embargo llega a afirmar lo siguiente: "son muchas las aportaciones de los pensadores a la pregunta antropológica, que nunca en el pasado el hombre conoció tantas cosas sobre sí mismo, pero al mismo tiempo que nunca como en nuestra cultura ignoró lo que en verdad es el hombre" 256 . Para el autor la causa es el olvido de la verdad del hombre: "La mayor laguna en las antropologías en nuestro tiempo es esta huida de la verdad del hombre. Son pocas las que tiene respuesta a las grandes cuestiones en torno al hombre: la existencia y la esencia"257.

Para resolver esta situación paradójica actual de la antropología desde el pensamiento lobatiano es importante tener presente la hipótesis planteada: El pensamiento lobatiano está orientado a la constitución y desarrollo de la metantropología. Su comprensión permitiría la construcción de un nuevo horizonte de conceptualización del humanismo cristiano para el contexto propio de la Universidad Santo Tomás de Colombia. Así mismo, para la comprensión del hombre desde la metantropología se desarrollará en tres

\footnotetext{
${ }^{254}$ LobAto, A. "La antropología de santo Tomás de Aquino y las antropologías en nuestro tiempo". Op. Cit., p. 91. 255 Ibid., p. 94.

${ }^{256}$ LOBATO, A. "La verdad integral sobre el hombre: La antropología tomista”. E-aquinas (2006), núm. 7, p. 4.

${ }^{257}$ LOBATO, A. "Antropología y metantropología. Los caminos actuales de acceso al hombre". Op. Cit., p. 38.
} 
momentos complementarios, a saber: La metantropología como fundamento; el homo viator como desarrollo, y el humanismo cristiano como culminación.

\section{3. 1 Metantropología como fundamento}

Según Abelardo Lobato, para superar la situación actual en que se encuentra la antropología, es decir, de tan diversos discursos sobre la comprensión del hombre o antropologías, se requiere una fundamentación que denomina metantropología porque se fundamenta en la metafísica o filosofía del ser. Como lo señaló: "La superación de la situación actual requiere poder realizar la fundamentación de la antropología en la metantropología, y la integración en aquella de las diversas antropologías”258. Así mismo, recalcó cuál ha de ser su competencia al afirmar: "Las antropologías actuales piden la superación en una antropología. A ésta le compete unificar, acoger y fundar todas las aportaciones de aquéllas"259.

En consecuencia, en la comprensión del hombre es importante el fundamento y Lobato cree encontrarlo en la metantropología. De modo que para él: "La antropología pide una metantropología, desde la cual tengamos justificado el fundamento" ${ }^{260}$. Al mismo tiempo considera que el hombre no puede ser fundamento de sí mismo por lo que la antropología requiere una fundamentación metafísica. De ahí que: "La antropología pide una ontología. El problema del hombre es el de ser finito, que no puede ser fundamento absoluto" ${ }^{261}$. Como también advierte el español: "El hombre de suyo no es fundamento, ni tiene la clave total de sí mismo. Necesita trascenderse y eso sólo lo hace en el ser. Desde el ser hay comprensión de la verdad del hombre"262.

Es así que Abelardo desarrolló una original doctrina del hombre denominada metantropología, como se ha indicado, por su fundamentación metafísica. El significado es propio del pensamiento lobatiano, mientras el significante lo recoge del pensamiento tomista. Puesto que la antropología de santo Tomás hunde sus raíces en su metafísica nueva y original al considerar al ser como acto. Como resalta Lobato: 
Tomás logró una filosofía peculiar, original, hasta hoy no superada, que culmina en su noción de ser como acto. Desde esta cima se puede dar razón del ser y de los entes, de la unidad y de la diferencia, de Dios y del mundo, en los límites en que se mueve la humana inteligencia. La filosofía es obra de la razón humana, una obra de la sabiduría que está llamada a descubrir el orden existente en lo real, y ser principio del orden que depende de la inteligencia en su propio acto y en los dominios de las potencias ${ }^{263}$.

No obstante, es preciso tener presente las siguientes consideraciones de metafísica señaladas por Abelardo: 1) "La metafísica se ocupa del ser"264. 2) "Su objeto es el ente"265. 3) "El ente es lo que es" ${ }^{266}$; 4) "Al hombre se le ha dado la inteligencia para el conocimiento del ente"267; 5) "La función de la inteligencia es la comprensión del ente a la luz del ser"268; 6) "La inteligencia humana no llega a ser sino a través de los entes concretos" ${ }^{269}$. Según Abelardo Lobato:

La dimensión óntica o metafísica recobra la línea del pensar trascendental y trata de dar razón del ser del hombre a partir del ente como primum cognitum. Por esa vía se llega a núcleo del pensar de Tomás, a la distinción del acto del ser, o del existir en acto, y del ser como acto. El ser en acto del hombre le trasciende y sólo es posible por un agente de poder infinito. Todo ente causado procede de otro, la vida es siempre una herencia"270.

Según el enfoque lobatiano, Tomás ha analizado las diferentes etapas que ha recorrido la filosofía hacia el ser, hasta llegar a la comprensión del ser como acto con el Aquinate:

La primera etapa en este caminar inteligente fue la de la superación de la barrera de la materia. Un salto costoso y una tentación perenne. Fue Anaxágoras el primero que logró ascender a un grado inmaterial del ser. La superación de la materia hizo posible la segunda etapa, la del encuentro con el ser espiritual. Lo descubre el hombre en su propio interior, a través de los actos de conocer y de amar que no implican materia y exige la dimensión espiritual. Una tercera etapa se realiza en la comprensión de la totalidad de los entes, vistos en su finitud, su unidad, su ordenación. El mundo no se basta a sí mismo. Su finitud exige una causa, un origen y un destino, una causa eficiente y una causa final ordenadora. El ente finito es compuesto. La mente logra la resolución de sus elementos integrante de esencia y existencia, de potencia y de acto de ser.

\footnotetext{
${ }^{263}$ LoBATO, A. "Filosofía y Sacra Doctrina en la escuela dominicana del s. XIII". Angelicum, Vol. 71 (1994), núm. 1, p. 31.

${ }^{264}$ LOBATO, A. “Afirmación de Dios, confirmación del hombre”. Communio, Vol. 23 (1990), p. 20.

265 Idem.

${ }^{266}$ LOBATO, A. Ser y belleza. Barcelona, España: Herder, p. 107.

${ }^{267}$ LoBATO, A. "Afirmación de Dios, confirmación del hombre". Op. Cit., p. 20.

${ }^{268}$ Idem.

${ }^{269}$ Ibíd., p. 21

${ }^{270}$ LOBATO A. "La verdad integral sobre el hombre: La antropología tomista". Op. Cit., p. 7.
} 
Tales son los elementos radicales del ente finito. En esta comprensión la inteligencia tiene una base para el salto definitivo hacia arriba.

El ser finito tiene origen por vía de creación, es una participación del ser finito. La existencia de los entes es punto de partida seguro para que la inteligencia remonte hasta el principio y la causa que los ha producido. Así se llega a la cuarta etapa, a la última resolución: es la de los elementos en el acto de ser y la de los efectos en la causa que los origina en un proceso de participación gradual. Tal es la genial penetración en el ente lograda por vez primera en la historia por Tomás de Aquino ${ }^{271}$.

Así mismo, Lobato realzó cómo Tomás llegó a la comprensión del ser como acto:

Aristóteles había iniciado la ascensión del pensamiento hacia el acto al proponer el alma humana como acto del cuerpo, y haber descubierto la actualidad y la potencialidad en lo real. Es el momento cumbre del pensamiento griego. Pero no pasó de ahí. Su metafísica es una teoría de la sustancia. En cambio Tomás, bien apoyado en él, intuyó la plenitud del acto de ser, y llega a la comprensión por vía de la resolución y de la participación. Así develó el ente a la luz del ser y la participación del ser en los entes. Su camino filosófico quedo trazado, el ser como acto es el acto de lo actos y la perfección de las perfecciones. El ser como acto es la raíz de todo cuanto acontece en el ente ${ }^{272}$.

En este orden de ideas, a la pregunta del Salmo 8: Señor Dios nuestro ¿qué es el hombre?, lo que busca Lobato con su respuesta es la verdad integral del hombre o una antropología integral. De manera que no responde únicamente desde la perspectiva antropológica sino también metafísica y teológica:

Para dar solución al problema del hombre y a los problemas humanos hay que situarlo, al estilo de los neoplatónicos, como anillo de conjunción entre dos horizontes, el del ser y el del hacerse, porque el hombre es y se hace. La esfera del ser lleva a la trascendencia, en la cual el hombre se entiende como la realización de uno de los modos de ser, y como fundado en el ser, religado a Dios. Por este lado no hay posible antropología sin antropología y sin teología. En el otro extremo del anillo humano está el mundo creado por el hombre como ser libre, un mundo cultural envolvente, admirable, en el cual el hombre está llamado desde dentro y desde fuera a comportarse conforme a lo que es y a lo que debe ser. La antropología está sometida a la primacía de los valores culturales, éticos y religiosos ${ }^{273}$.

\footnotetext{
${ }^{271}$ LobAto, A. "Afirmación de Dios, confirmación del hombre". Communio, Vol. 23 (1990), p. 21.

272 LobATo, A. "La persona en santo Tomás de Aquino". Op. Cit., p. 23.

${ }^{273}$ LoBATO, A. Dignidad y aventura humana. Op. Cit., p. 13.
} 


\section{3. 2 El homo viator como desarrollo}

Uno de los conceptos más constantes de la antropología lobatiana es el de homo viator. Para este abordaje "por naturaleza el ser humano es siempre un homo viator"274. Así mismo, el significado de dicho concepto se reviste de matices, entre ellos el de itinerante $^{275}$, el de camino ${ }^{276}$ (Lobato, 1996, p. 5), el de peregrino ${ }^{277}$; en efecto, para Abelardo "el hombre es un ser en camino, un itinerante, un peregrino del absoluto, homo viator" $^{278}$.

Al pensamiento lobatiano le interesa además del ser del hombre como fundamento, el desarrollo del homo viator, es decir, el hacerse hombre. Más aún, para Lobato: "Todo ser humano, mientras peregrina en el mundo, es un ser en camino, es y se hace. $Y$ entre todas las cosas que está llamado a ser, ninguna es tan importante como la de hacerse nada menos que todo un hombre"279. De ahí que para Lobato existe una paideia humana que consiste en hacerse hombre, es decir, en llegar a la madurez humana en sus diversas posibilidades de perfección.

Además, como pedagogo conduce con su enseñanza o doctrina al desarrollo de las facultades y dimensiones humanas. Como él mismo manifiesta: "Se confía al pedagogo dirigir al adolescente hacia la plenitud humana. Los latinos la entendieron como humanitas, desarrollo de las potencias y posibilidades del hombre" ${ }^{280}$. Así mismo, Lobato es fiel y seguidor del pensamiento tomista al considerar:

La antropología tomista no se detiene en el ser del hombre, dedica mucho más espacio al hacerse hombre, a la conquista del fin que es el camino del retorno a Dios. Cuando el sujeto humano logra las virtudes que no sólo lo hacen sabio, o artista, sino que lo hacen buen hombre, puede decirse que el hombre lleva consigo el mundo y vuelve a Dios. En este camino son

\footnotetext{
274 Lobato, A. "Senderos abiertos hacia el nuevo humanismo". Espíritu (2001), núm. 124, p. 4.

275 LOBATO, A. "El futuro como dimensión humana”. Angelicum. Vol. 49 (1972), pp. 162- 195.

276 LoBATO, A. "El problema del hacer humano". Salmanticensis. Vol. 13 (1996), fasc. 2, p. 5

277 Lobato, A. "La persona en Santo Tomás de Aquino". Familia et vita (2000), núm. 2, p. 107.

278 LoBATO, A. "La aportación de los Dominicos en el S. XVI a la defensa y promoción del hombre". Angelicum. Vol. 70 (1993), pp. 363-415.

${ }^{279}$ LobATO, A. (2006). "Lo sacro y la religión en santo Tomás de Aquino". Doctor Communis. p. 150.

${ }^{280}$ LoBATo, A. Tomás de Aquino, arquitecto de la vida universitaria. El profesor ideal de la paideia tomista. Bogotá: Universidad Santo Tomás, 2003, p. 43.
} 
decisivas las virtudes morales, que no sólo hacen bueno el acto, sino que hace bueno al hombre. Este es el fin intentado por Dios al crear el hombre del limo de la tierra y ponerlo en el paraíso ${ }^{281}$.

Para el desarrollo del homo viator o hacerse hombre se proponen a la luz del pensamiento lobatiano nueve senderos o dimensiones que es fundamental recorrer. Sin embargo, los vamos a llamar paideia, es decir, camino de formación humana. El camino que hace el homo viator es ascendente, hasta alcanzar el hombre ejemplar que es Jesucristo.

1. La paideia de lo cósmico. Para el hombre y toda persona es importante que se pregunte por el lugar que ocupa en el cosmos. Al decir de Lobato: "El hombre necesita saber dónde se encuentra, descubrir su puesto en el universo"282. El hombre forma parte del mundo y no existe hombre sin mundo. Del mismo modo, el hombre necesita descubrir el puesto en el universo porque es una parte del todo, pero a su vez diferente.

Asimismo, el hombre debe ir descubriendo en su conciencia y de su experiencia con la realidad que hay un principio trascendental como causa de lo existente, y el mundo en el que habita es lugar de humanización. Como advierte Lobato: "El mundo ha sido comprendido como totalidad, producido por un artista inteligente y con el fin de ser lugar de los seres humanos" ${ }^{283}$. Aunque el universo participa de la bondad de Dios, el hombre alcanza un mayor grado de participación al ser creado a imagen de Dios. Al decir de Lobato:

(...) a pesar de su pequeñez el hombre descubre que todo lo cósmico ha sido credo para él; y que se le ha dado el dominio para que lo administre y gobierne mediante la cultura; el mundo es para el hombre, conforme a este principio antrópico, y por más que sea muy grande, no es el mundo el que contiene el hombre, sino que es el hombre el que contiene el mundo ${ }^{284}$.

Para Tomás de Aquino el hombre es síntesis de la creación, es decir, una obra de Dios. En Lobato el concepto de microcosmos o mundo en pequeño es el que define mejor al hombre. Además el hombre por su condición de espíritu encarnado es ciudadano de dos mundos que debe conjugar: el ser ciudadano del mundo corporal y del mundo material. Como lo explica Lobato:

\footnotetext{
${ }^{281}$ Lobato, A. "El hombre, síntesis de la creación”. En: José M. Petit Sullá - José M. Romero Baró (Eds.). Actas del congreso "La síntesis de santo Tomás de Aquino". Barcelona: Publicacions i edicions de la Universitat de Barcelona, 2002, p. 136.

282 LOBATO, A. "La verdad integral sobre el hombre: La antropología tomista". Op. Cit., p. 9.

283 LoBAto, A. "El hombre, síntesis de la creación”. Op. Cit., p. 128.

${ }^{284}$ Ibíd., p. 5.
} 
El hombre es como el anillo de conjunción de los dos mundos, el espiritual y el corporal. Sus pies están bien asentados en la materia corpórea y su cabeza entra en conexión con la esfera espiritual. Es un compuesto de espíritu y materia. Es ciudadano de dos mundos. Por la corporeidad es ciudadano del mundo de los cuerpos, y es el cuerpo más perfecto de todos los existentes, en orden al cual están hechos todos los demás. Por el espíritu es conciudadano del mundo espiritual, es el árbol con las raíces hacia arriba, capaz de trascender la materia, capaz del sumo ben, capax Dei, como dice san Agustín ${ }^{285}$.

A todas luces, el hombre está llamado a cuidar el mundo y al mismo tiempo a transformarlo por medio de su inteligencia y sus manos. Como lo enfatiza Lobato: "El ser humano no sólo vive inmerso en un mundo admirable, que en cierto modo es un espejo de quien lo ha creado para el hombre, sino que abriga la certeza de que el Creador ha querido contar con él en su gobierno y desarrollo"286. Así mismo, el hombre como co-creador adquiere una responsabilidad con el planeta: evidenciar una huella de su ser creativo y no destructivo.

Ahora bien, la huella del hombre en el mundo es estética. Hay una belleza en la creación que es imagen de la belleza divina, que el hombre contempla y es vía de acceso al conocimiento de Dios. No obstante, en Cristo y en el acontecimiento de la encarnación se condensa la belleza de Dios y con ella la belleza del hombre perdida por el pecado. Como afirma Lobato: "El hombre es una maravilla de la Creación cuando se contempla en los dos ejemplares que han salido de las manos de Dios, en Jesucristo, el más hermoso de los hombres, y en Adán y Eva"287.

De manera que hay una belleza antropológica, del hombre en cuerpo y alma, en lo que es y hace. La primera se da porque el hombre es imagen y semejanza de Dios y se hace en la medida en que el hombre pone en acto sus facultades: "El hombre está llamado a la conquista de la belleza en su plenitud personal" ${ }^{\text {288; }}$; la segunda en la medida en que el hombre despliega sus capacidades en la belleza de lo que hace. De manera que el hombre es creador de belleza porque con su inteligencia y sus manos devela la belleza escondida en los entes.

2. La paideia de antropología integral. Una de las expresiones constantes de Lobato en la comprensión del hombre es la de antropología integral o verdad integral del hombre. Con dicha expresión lo que indica el tomista español es totalidad o una unidad conformada por

\footnotetext{
${ }^{285}$ Ibíd., p. 134.

${ }^{286}$ LOBATO, A. "El horizonte estético del hombre medieval. La perspectiva tomista”. Op. Cit., p. 59.

${ }^{287}$ Ibíd., p. 62.

${ }^{288}$ Ibíd., p. 68.
} 
dos principios diferentes pero constitutivos de la realidad que llamamos Hombre. Como lo indica él mismo: "El hombre es un compuesto de dos elementos contrarios que se unen de modo sustancial como materia y forma, es decir de cuerpo y alma"289. Sin embargo, infiere con santo Tomás lo siguiente: "El alma es forma sustancial del cuerpo, pero no es forma material, sino emergente por su condición espiritual" ${ }^{290}$. Por su naturaleza humana el hombre está llamado a hacerse en el ejercicio y perfeccionamiento de sus facultades: "El desarrollo del hombre se lleva a cabo mediante el despliegue de las posibilidades del alma en el cuerpo" ${ }^{\prime 291}$.

Sin embargo, para Lobato: "El olvido del alma ha sido fatal para la cultura de occidente. El peso de la corporeidad ha oprimido todo lo humano"292. De ahí que es fundamental la teoría hilemórfica desarrollada por el Aquinate para dar razón del alma humana y con ella del hombre. "Pues el alma es lo que da origen a la corporeidad humana a su vez porque es la que da el ser y donde no hay alma no se puede hablar de lo humano"293. De modo que ante la pregunta por el hombre para Lobato hay dos respuestas:

Parte de la existencia: el hombre está ahí en cada uno de los singulares existentes. Esto se comprueba en la realidad. La otra es la que nos indica su esencia. Por ser compuesto, tiene una forma y una potencia. La forma da razón del compuesto. Los seres se conocen por su forma ${ }^{294}$.

De esta comprensión del hombre en su existencia y esencia se sigue la tarea o paideia a la que el hombre en cuanto hombre está llamado todo los días y es a la plena realización como persona. Como lo manifiesta Lobato:

La tarea más importante entre las actividades humanas no es la del homo faber, la de producir objetos útiles o bellos, sino la del homo sapiens, la que brota de la misma forma humana y se ocupa de lo que es más propio del hombre, en cuanto ser racional ${ }^{295}$.

Empero, el ser racional no es un olvido del cuerpo o un rechazo de él al estilo platónico sino del hombre en su compuesto. Pues el hombre está llamado a realizarse de manera integral y en el ejercicio de las facultades del alma, el cuerpo por medio de sensibilidad es su punto de partida para el conocimiento. Según Lobato:

\footnotetext{
${ }^{289}$ LOBATO, A. "El horizonte estético del hombre medieval. La perspectiva tomista”. Op. Cit., p. 61.

290 Idem.

291 Idem.

292 LOBATO, A. "La verdad integral sobre el hombre: La antropología tomista". Op. Cit., p. 6.

293 LOBATO, A. "Senderos abiertos hacia el nuevo humanismo". Op. Cit., p. 16.

${ }^{294}$ LOBATO, A. Dignidad y aventura humana. Op. Cit., p. 85.

295 LoBATO, A. "El horizonte estético del hombre medieval. La perspectiva tomista". Op. Cit., p. 68.
} 
El hombre es ser racional, no es una pura inteligencia al estilo platónico o cartesiano, sino que es un viviente sensible, que requiere del ejercicio de los sentidos para conocer. Todo conocer tiene su punto de partida en la sensibilidad. Nada hay escrito en su alma cuando viene al mundo ${ }^{296}$.

Hacerse hombre implica poner en acto las facultades humanas a través de las virtudes. En clave lobatiana:

La virtud es un hábito que eleva a la potencia y a sus actos al máximo de sus posibilidades. Son tres las operaciones que ejercita el hombre por su condición de animal racional: conocer, obrar, hacer. Cada una de estas actividades admite una escala de posibilidades, que dan origen a tres tipos de virtudes: intelectuales, artísticas, morales. Las intelectuales ayudan a la conquista de la verdad de las cosas, las artísticas cooperan en el dominio del mundo a través del poder de las manos dirigidas por el entendimiento práctico, y las morales ayudan al dominio del acto humano y a la realización del hombre mismo. Como virtudes todas son camino de perfección humana, porque todas son perfectivas de la potencia y de su objeto ${ }^{297}$.

En la formación humana las virtudes son fundamentales. No obstante para entre las virtudes para Abelardo es más importante el desarrollo de las virtudes morales. La formación humana :

Las virtudes morales son las necesarias para la vida humana. El hombre no se dice bueno por las virtudes intelectuales sino por las virtudes morales. Cuanto más poder acumula el hombre en su mente o en sus manos, es más peligroso, si el hombre no es bueno ${ }^{298}$.

La dimensión integral del hombre tiene que hacerse a través del desarrollo de las virtudes morales, las que hacen buena la obra y bueno al hombre. $Y$ para este cometido es importante el desarrollo de las virtudes humanas. A este propósito comenta:

La virtud de la prudencia es la más radical, la que dignifica al hombre y lo hace 'buena persona'. La virtud de la justicia es la virtud de la alteridad, la que hace posible el encuentro del hombre con el hombre en paz y concordia. La virtud de la templanza dice un orden explícito a la dignidad del sujeto humano. La 'honestas' hace al hombre honore dignus. La templanza reclama para sí un decoro especial, una belleza más espléndida. En cambio los vicios de la intemperancia rebajan la dignidad del hombre al nivel de la vida animal ${ }^{299}$.

\footnotetext{
${ }^{296}$ Ibíd., p. 63.

297 LOBATO, A. (2006). "Lo sacro y la religión en Santo Tomás de Aquino". Op. Cit., p. 149.

298 LOBATO, A. "El sentido moral en situación de peligro en la cultura contemporánea". Angelicum, Vol. 72 (1995), p. 52.

299 LoBATo, A. "La dignidad del hombre en Santo Tomás de Aquino". Carthaginensia. Vol. 6 (1990), núm. 9 , p. 151.
} 
El hombre se hace en la historia como homo viator porque es un ser histórico. El modo de ser en el tiempo se llama historia. Además el proceso de hacerse hombre es relacional es decir en compañía del hombre con el hombre se realiza el proceso histórico de humanización. "El hombre con el hombre realiza el proceso de humanización, de personalización, y ello da origen a otro componente del hombre: la historia. El hombre es un ser histórico, que es y se hace con los demás" ${ }^{300}$.

La historia se hace lineal en las etapas sucesivas de presente, pasado y futuro. No obstante, la humanización del hombre es ascendente, más de altura que de longitud. De hecho, el ascenso humano es posible en la historia que el hombre construye. El hombre es atraído a la construcción desde el futuro por lo que la actitud del hombre es dinámica no estática. "El futuro no es lo que llega, lo por-venir que se recibe pasivamente, sino que se prepara, lo que se anticipa, a base de pro-yectos" ${ }^{\text {"301. }}$.

3. La paideia de la persona. La palabra persona ha tenido un largo proceso desde su origen hasta su significado en nuestros días. Todo hombre es persona y como tal está llamado a hacerse y vivir en plenitud. Para Lobato, "todo parte de la persona, se ordena a la persona como un absoluto que está llamado a vivir su plenitud"302. Así las cosas, para Lobato en su origen y desarrollo han confluido dos tradiciones: "una etrusca que heredan los romanos, y otra griega que perfeccionan los cristiano" ${ }^{303}$. Sin embargo, los dos casos se generan en la experiencia del teatro. De modo que en la primera tradición la palabra usada para designar la máscara ha sido phersuna, de donde los romanos la adujeron por persona. Según Lobato: "La tumba degli auguri podría ser el primer testimonio histórico de la palabra que designa la máscara" ${ }^{304}$; en la segunda tradición para expresar la misma

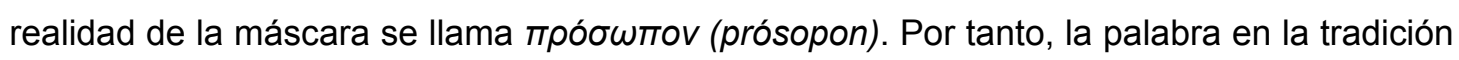
romana y griega significó inicialmente máscara teatral.

Según Lobato, en el desarrollo de la palabra persona, Séneca es el primero en usarla para referirse al individuo como persona, en este caso al emperador Claudio como sujeto singular y como persona ${ }^{305}$. Así se pasa de la máscara del teatro a los individuos humanos.

\footnotetext{
${ }^{300}$ LoBATO, A. "Los derechos humanos en el pensamiento contemporáneo". Verbo. (1980), núm. 189-190, p. 1176

${ }^{301}$ LOBATO, A. "El futuro como dimensión humana". Angelicum, Vol. 49 (1972), p. 164

302 Lobato, A. Tomás de Aquino, maestro de maestros. Op. Cit.,p. 84.

${ }^{303}$ LoBATO, A. Dignidad y aventura humana. Op. Cit., p. 100.

${ }^{304}$ Lobato, A. "La persona en Santo Tomás de Aquino". Op. Cit., p. 16

305 LoBATO, A. Dignidad y aventura humana. Op. Cit., p. 16.
} 
Por otra parte, en la perspectiva cristiana recurre a la palabra persona para referirse al misterio de la Trinidad y de la Encarnación. Así mismo, Tertuliano es el pensador cristiano que hace la distinción entre naturaleza y persona. Por lo cual se pasa del teatro a la intimidad del misterio divino.

Para Lobato la palabra persona ha conocido tres momentos en la historia a saber: la metafísica, la psicológica y la fenomenológica. "La etapa metafísica abrió la pista a la psicología y ésta a la fenomenología. En la primera se atiende más bien al ser, en la segunda al conocer, y en la tercera se privilegian las relaciones" ${ }^{\text {306 }}$. Analógicamente, en el primer momento el filósofo Boecio fue el primero en clarificar e introducir en la cultura occidental con su definición de corte aristotélico en el que indica el género y la diferencia: persona es la sustancia singular de naturaleza racional.

Posteriormente, se produjo el encuentro del concepto dignidad y persona. Para Lobato, "Alejandro de Hales incorpora la dignidad a la noción de persona: Persona est hypostasis proprietate ad dignitatem pertienente" ${ }^{307}$. Finalmente en esta etapa el teólogo Tomás de Aquino hace una definición metafísica de la persona desde el acto de ser o del ser como acto: "Ser persona implica lo más elevado del ente, tanto el acto de ser cuanto los modos perfectos de realizarse" ${ }^{\text {"308 }}$. Abelardo sintetiza tres notas fundamentales en la definición de persona desde el Aquinate:

Tres notas destacan en la persona: la primera es una totalidad, no una parte; la segunda es la subsistencia, un ser que se apoya en sí mismo, que subsiste; y la tercera, que tiene un rango de naturaleza racional. Las tres notas nos sitúan ante un ser singular, concreto, que no pude ser de otro, ni con otro, ni para otro porque le compete una clausura ontológica, que la hace incomunicable; una naturaleza tan noble, que implica el modo más alto de ser, el espiritual ${ }^{309}$.

El segundo momento histórico es la vuelta al sujeto, es decir a la interioridad subjetiva. En efecto, "la persona no se define por su peso ontológico, sino por su presencia, porque se conoce, percibe el mundo, tiene actos que le son propios" ${ }^{310}$. El tercer momento es el fenomenológico que se caracteriza por una vuelva a la persona desarrollado por el personalismo. Al decir de Lobato: "El personalismo ha despertado el tema de la persona y

\footnotetext{
${ }^{306}$ Ibíd., p. 103.

307 Ibíd., p. 105.

308 Idem.

${ }^{309}$ Lobato, A. Tomás de Aquino, maestro de maestros. Op. Cit., p. 85.

${ }^{310}$ LoBATO, A. Dignidad y aventura humana. Op. Cit., p. 106.
} 
de sus relaciones con la totalidad. Su virtud ha sido la vuelta a esta cima del sujeto, su límite intentar reducirlo todo a la persona"311.

En la tarea de hacerse hombre es importante el concepto de personalidad. "La persona es un don, la personalidad una conquista. Consiste en la adquisición de la madurez en los estilos de ser, de comportarse, a actuar. La personalidad sigue a la persona"312. Para su desarrollo, según Lobato, son fundamentales las relaciones interpersonales que tienen lugar en la persona. Así mismo, para Lobato son tres las que la constituyen y sin las cuales no es posible la vida de la persona: el encuentro cara a cara, el diálogo y la autodonación por el amor.

Efectivamente, el encuentro se da entre personas diferentes y a su vez origina la convivencia humana. La corporeidad es lugar de encuentro hacia fuera con las cosas y las demás personas sobre todo a través del órgano de la mano. Además, a nivel interpersonal la familia es lugar de encuentro que se convierte en el inicio para otros lugares o espacios de encuentro. Pero no son encuentro pasivos sino encuentro de formación y crecimiento: "la persona se va formando en los encuentros con los otros, por lo que recibe y por lo que $\mathrm{da}^{\text {"313. }}$. Así mismo, el rostro humano ha sido el primer lugar de encuentro interpersonal, como lo narra el texto bíblico, de dos personas diferentes que se encuentran cara a cara para vivir en mutua comunión. Lobato arguye al respecto: "Mujer y varón se encuentran llamados a vivir frente a frente, a mirarse a la cara, donde se encuentran las mejores expresiones del ser personal” ${ }^{314}$. Además para Lobato:

$\mathrm{Si}$ todo el cuerpo es significante, el lugar privilegiado de los signos de la corporeidad es el rostro humano. Es aquí donde se contempla la maravilla del hombre. Los seres humanos expresan sus relaciones cara a cara, y sobre todo a través de la mirada ${ }^{315}$.

El otro lugar de encuentro es la palabra. Ésta es el medio más apto para el hombre comunicarse. La comunicación se da entre las personas capaces de lenguaje: "La palabra es un medio excelente de relación interpersonal. Se le confían tres dimensiones de la vida de la persona: expresa lo interior, significa lo pensado, comunica con otro sujeto". La palabra humana es lugar de crecimiento personal y comunitario. De ahí que el proceso

\footnotetext{
311 Ibíd., p. Op. Cit., p. 107.

312 LOBATO, A. "La mujer y el varón cara a cara. El problema de la diferencia". Angelicum, Vol. 72, (1995). p. 570.

313 LoBAto, A. Dignidad y aventura humana. Op. Cit., p. 115.

314 LOBATO, A. "La mujer y el varón cara a cara. El problema de la diferencia”. Op. Cit., p. 565.

${ }^{315}$ LoBAto, A. "La paideia cristiana de la libertad en relación interpersonal". Sophia, Colección de Filosofía de la Educación. (2007), núm. 3, p. 56.
} 
pedagógico de los diferentes espacios comunitario y de relaciones interpersonales se configura a través de la palabra.

Finalmente, el amor es una tercera relación interpersonal necesaria para la vida de la persona. El amor acerca y crea comunidad. El encuentro de las personas está habitado por el amor. Para Lobato: "Lo propio del amor es darse a sí mismo como don gratuito a los demás. El amor es la fuerza unitiva” ${ }^{316}$. Para él la fuerza del amor es arquitecta del hombre. Según este autor: "Cada hombre es una edificación del amor. El amor construye la personalidad del hombre. El sujeto personal se va construyendo desde el amor ${ }^{317}$.

4. La paideia de la dignidad. Toda persona es digna por su misma naturaleza. Pero la dignidad es un don y al mismo tiempo una tarea: vivir con dignidad. Entonces la dignidad resulta una segunda acepción, una conquista o una aventura humana. Como lo manifiesta Lobato: "El caminar del hombre hacia la dignidad es su gran aventura"; así mismo: "El muy noble por su origen, el homo viator, se dignifica mientras va de camino hacia su meta" ${ }^{\text {"318. }}$. En su sentido etimológico la palabra dignidad para Lobato:

Todo parece indicar que su origen lingüístico más remoto es sánscrito. Procede de la raíz dec, la misma que se encuentra en vocablos afines, como decoro, decente. La flexión digno viene del latín. Esta lengua unió la raíz dec con la terminación nus. Así resulto dec-nus, que con el tiempo evolucionó a dignus ${ }^{319}$.

No obstante, para Lobato la dignidad de la persona debe partir de un fundamento ontológico o metafísico. Así mismo, como lo advierte Lobato:

No hay otra vía para fundar la dignidad que no incluya la vía metafísica. Esa es la vía del ser. El hombre es digno por su mismo ser. El ser del hombre es personal. De la persona le viene al hombre la dignidad radical. De esa raíz originaria, común a todo hombre, proceden todas las otras perspectiva de la dignidad humana. Sin ella no tiene consistencia ${ }^{320}$.

Lobato recurre a tres condiciones que considera indispensable para adentrarse en la dignidad: "La primera es la atención a la totalidad. La dignidad humana implica la totalidad de lo humano en su unidad y su complejidad ${ }^{321}$; la segunda es la trascendencia. En el

\footnotetext{
${ }^{316}$ LoBATO, A. Dignidad y aventura humana. Op. Cit., p. 119.

317 LOBATO, A. "Amor humano y familia cristiana en el alba del siglo XXI". Vol. 33 (1994), p. 741.

318 Lobato, A. Dignidad y aventura humana. Op. Cit., p. 19.

${ }^{319}$ LOBATO, A. Dignidad y aventura humana. Op. Cit., p. 56.

${ }^{320}$ LoBATo, A. "La dignidad del hombre en Santo Tomás de Aquino". Op. Cit., p. 146.

${ }^{321}$ LoBATO, A. Dignidad y aventura humana. Op. Cit., p. 47.
} 
hombre hay algo que supera lo humano ${ }^{322}$; la tercera es la universalidad. Todo hombre es digno. Esto es una gran verdad" ${ }^{\text {323. }}$.

La dignidad parte de un fundamento ontológico pero a su vez es un regalo. En un primer momento el hombre es digno por su ser, por el hecho de ser hombre. La dignidad se manifiesta en su naturaleza racional y por ser persona. En segundo lugar la dignidad se desarrolla en un proceso, en una dimensión ética, en el desarrollo de todas las capacidades humanas. De tal manera que puede ser conquista o pérdida. Para Lobato: "La dignidad inherente y radical es un regalo, la dignidad adquirida una gran aventura, una lenta conquista, la dignidad perdida una desventura humana”324.

La dignidad del hombre se constituye en fundamento de los derechos humanos. Como lo señala Lobato: "La dignidad humana, por diversos motivos, es la fuente de los derechos humanos" ${ }^{325}$. Aunque el origen de los derechos humanos son las inclinaciones de la naturaleza humana. Es así que Lobato los haya en Tomás de Aquino cuando señala:

En el célebre artículo 2 de la cuestión 94 de la I-II de la Summa Santo Tomás deja entrever cinco grandes inclinaciones de la naturaleza humana que dan origen a los derechos humanos. El hombre tiene una profunda inclinación connatural: al bien, a la conservación del propio ser, a la trasmisión de la vida, a la búsqueda de la verdad, y a la vida justa y pacífica en la sociedad ${ }^{326}$.

Los derechos humanos son caminos de humanización del hombre. Así mismo todo lo que atente contra las inclinaciones de la naturaleza humana es una amenaza al hombre. Además los derechos humanos se fundamentan en "la humanidad del hombre, su libertad y su dignidad personal" ${ }^{327}$. De manera que: el hombre tiene el gran derecho a ser plenamente hombre; el hombre ha nacido para la libertad; el hombre tiene derecho a realizar su personalidad integral.

5. La paideia de la libertad. El hombre es un ser libre. En el camino de ascenso humano o de hacerse la libertad es un don y una tarea: "Es un don la libertad, y pertenece al hombre ser libre" ${ }^{328}$. No obstante, la libertad para ser real tiene que estar liberada, en efecto,

\footnotetext{
322 Idem.

${ }^{323}$ Idem.

324 Ibíd., p. 229.

${ }^{325}$ LOBATO, A. "La dignidad del hombre y los derechos humanos". Op. Cit., p. 101.

${ }^{326}$ LobAto, A. "Nuevos horizontes de los derechos humanos. La Iglesia y los derechos de los pueblos". Angelicum Vol. 73, (1996), p. 214.

327 LOBATO, A. "Los derechos humanos en el pensamiento contemporáneo". Op. Cit., p. 1196.

${ }^{328}$ Lobato, A. Tomás de Aquino, maestro de maestros. Op. Cit., p. 101.
} 
educada para su conquista: "La libertad implica una constante liberación"329. Porque de lo contrario como advierte Lobato: "El hombre es un ser libre y la libertad es un gran poder de promoción y de destrucción del hombre"330.

El punto de partida para tratar la libertad es la del hombre en su realidad de cuerpo y alma, es decir el hombre libre y no una parte de él. Sin embargo, la libertad humana obtiene su principio en la inteligencia humana: "Raíz y fundamento de la libertad es la inteligencia. Ella no es libre frente a su propio objeto, pero origina la libertad de la voluntad que se inclina al bien siguiendo la dirección de la razón" ${ }^{331}$. Pero al mismo tiempo la libertad está orientada al bien del hombre, al del bien y la verdad, como afirma Lobato: "Todo se orienta hacia la libertad y ésta se dirige a la conquista del bien y de la verdad"332.

La libertad para ser real y vivida a plenitud debe ser liberada: "La libertad implica una constante liberación” ${ }^{\text {333 }}$. Además, requiere la libertad antropológica en su fundamento no puede estar condicionada por factores internos o externos. Es así que para él: "Ser libre implica algunas condiciones: no estar determinado o coaccionado desde fuera ni desde dentro" ${ }^{334}$. El alma es la fuente originaria de las potencias o facultades. Es así que por las facultades de la razón y la voluntad y de su desarrollo educativo el hombre va liberando la libertad: "Ser libre implica tener dominio de sí mismo, estar por encima de las circunstancias" 335 . La elección es el acto por excelencia de la libertad, no obstante como lo indica Lobato: "Comprometen la libertad humana los diversos actos del sujeto, la elección sobre todo. Porque elegir es determinarse, hacer esto y no lo otro, mientras que ser libre es poder hacer esto y lo otro". 336

Desde la perspectiva del pensamiento lobatiano hay tres lecturas de la libertad: la griega, la cristiana y la moderna ${ }^{337}$. Todas ellas parten de una experiencia diversa de libertad. De manera que para la cultura griega la libertad está relacionada con la experiencia de liberación del dominio de otras culturas; en la cultura moderna que es poscristiana se

\footnotetext{
${ }^{329}$ LoBATO, A. Dignidad y aventura humana. Op. Cit., p. 94.

${ }^{330}$ LobAto, A. Santo Tomás arquitecto de la vida universitaria. El profesor ideal de la paideia tomista. Bogotá: Universidad Santo Tomás, 2002, p. 55.

${ }^{331}$ LOBATO, A. "El valor y la libertad humana". Estudios filosóficos. Vol. 8 (1959), núm. 17, p. 122.

${ }^{332}$ LoBATo, A. Santo Tomás arquitecto de la vida universitaria. El profesor ideal de la paideia tomista. Op.

Cit., p. 57.

${ }^{333}$ LOBATO, A. Dignidad y aventura humana. Op. Cit., p. 94.

${ }^{334}$ Ibíd., p. 93

${ }^{335}$ Idem.

${ }^{336}$ LOBATO, A. "El valor y la libertad humana". Op. Cit., p. 117.

${ }^{337}$ LobAto, A. "La filosofía cristiana de la libertad". Sapientia. Vol. 34 (1979), núm. 133-134, p.
} 
centra en hacer de la libertad un valor absoluto, es decir, el hombre es libertad; para el cristianismo la liberta relaciona al hombre con Dios.

Por su condición re-ligante con Dios el hombre es un ser dialogal, abierto, capaz de Dios. Se le ha colocado en el mundo para que lo domine, tiene a su lado al hombre para que comparta con él su existencia, pero lleva sobre sus hombros el peso de la respuesta que da a su propio destino, porque es árbitro de sí mismo y de la historia que se le confía ${ }^{338}$.

Para Lobato la libertad del hombre se realiza en sus relaciones con el mundo, consigo y con su apertura al ser. En dichas relaciones se considera tres momentos históricos constitutivos de la libertad: el cosmológico, el antropológico y el ontológico. En el primero apunta hacia la relación constante del hombre con el mundo. El hombre se siente enfrentado con las leyes de la naturaleza y muchas veces su vida determinada por ella; en el segundo momento la libertad se descubre como carácter y poder del hombre, algo que le compete por su misma realidad humana. Es la libertad del hombre frente al mundo porque toma conciencia de sí mismo y se posee; en el tercer momento el hombre como ser abierto es capaz de trascendencia, va más allá de sí mismo, se sitúa en un horizonte sin fronteras. Es decir que el hombre es pura libertad.

Se pregunta Lobato con respecto a la libertad: ¿cómo orientar la libertad de modo que mediante los actos libre, sea el hombre un ser en verdad libre y liberado? ${ }^{339} \mathrm{~A}$ lo que responde que el hombre tiene dos grandes ayudas: la conciencia y la ley. De modo que para este dominico:

La moralidad supone la conciencia como criterio del bien y del mal en el sujeto, testigo y juez, que anuncia en el santuario de cada uno de los principios de su conducta, y aprueba y reprueba, aplaude y condena, testifica y remuerde. La conciencia implica una referencia a una regla desde la cual se juzga si es recta la acción o no es, si conviene al ser racional o no. El criterio de la conciencia es necesario, pero no suficiente. Puede estar deformado por la cultura o las pasiones. Por encima de la conciencia está la ley natural, participación de la ley eterna en la creatura racional, de la cual brotan las grandes inclinaciones hacia el ser, el bien, la verdad ${ }^{340}$.

Además de la conciencia y la ley natural, Lobato introduce la persona de Cristo desde la sentencia evangélica "conoceréis la verdad y la verdad os hará libre" ${ }^{341}$, es decir, no hay

\footnotetext{
${ }^{338}$ Idem., p. 297.

${ }^{339}$ LobAto, A. Tomás de Aquino, maestro de maestros. Op. Cit., p. 101.

340 LoBATO, A. Santo Tomás arquitecto de la vida universitaria. El profesor ideal de la paideia tomista. Op. Cit., p. 56.

${ }^{341}$ Lobato, A. Tomás de Aquino, maestro de maestros. Op. Cit.
} 
libertad sino en la verdad. La verdad viene siendo una persona, Jesucristo, y el encuentro con Él y su seguimiento se constituyen en el punto de partida de la libertad. Desde esta perspectiva cristiana: "Ser llamado a la libertad es estar implicado en una constante liberación como respuesta. La libertad es como la atmósfera del cristiano. Vive desde la libertad, en la libertad y para la libertad”342.

6. La paideia de la palabra. El hombre es de los animales más comunicativos. Como lo indica Lobato: "El hombre ha sido designado desde antiguo como animal que tiene palabra a diferencia de los animales que son muchos y no hablan"343. El hombre puede utilizar muchas formas de comunicarse con sus semejantes pero la manera más excelente es el lenguaje: "El hombre es homo loquens, el ser que tiene lenguaje mediante el cual comunica de persona a persona" ${ }^{344}$.

El lenguaje es humano y a su vez mediación para comunicar nuestra realidad interna y externa, pensada o vivida: "El lenguaje es nuestra mediación de la realidad. Donde desaparece el lenguaje se pierde el hombre. Pero el lenguaje humano es de la palabra hablada. El hombre necesita significar y comunicar lo que vive" ${ }^{\text {"345. }}$.

El lenguaje tiene un fundamento antropológico y metafísico. La palabra humana es espiritual pero se origina en la realidad, es decir, hablamos de lo que ha pasado por nuestros sentidos, que llega a la mente y la expresamos. Como lo señala Lobato: "La comunicación tiene como punto de partida y de encuentro común el ser. Lo espiritual se ordena al ser para aprehenderlo, para poseerlo, para llenarse de él. Toda comunicación supone este punto de partida"346.

El hombre por medio del lenguaje hablado expresa ideas, pensamiento, emociones, pero a su vez crea comunión entre las personas. "El hombre habla porque no está a solas. Habla para comunicar con otros hombres con los cuales convive en la familia y en la sociedad” ${ }^{347}$. La comunicación diáfana se da entre dos sujetos capaces de lenguaje, cuyas condiciones

\footnotetext{
${ }^{342}$ LoBATO, A. "La filosofía cristiana de la libertad". Op. Cit., p. 1232.

343 LoBATO, A. Dignidad y aventura humana. Op. Cit., p. 117.

${ }^{344}$ Lobato, A. El Ave María. La espositio de Santo Tomás. Comentario de Abelardo Lobato Casado, O. P., (S. F.) p. 6.

345 LobATo, A. "Experiencia de Dios y palabra humana en Teresa de Jesús". Angelicum, Vol. 59 (1982), núm. 1, p. 345.

${ }^{346}$ LOBATO, A. "Primacía de lo intelectual en la comunicación interpersonal". Revista de Filosofía (1962), núm. 80-81, p. 92.

${ }^{347}$ LoBATO, A. "El lenguaje y la palabra en Tomás de Aquino". Revista de filosofía. (1989), núm. 65, p. 141.
} 
son las de parlante y oyente: "La relación de sujeto parlante se establece con otro sujeto oyente, y entre ambos nace el diálogo, y entre muchos el coloquio" ${ }^{348}$. Pero hay un aspecto que no podemos olvidar en la comunicación y es que la palabra y es el silencio que la antecede: "El silencio es anterior, originante. La palabra sólo puede brotar, ser trasmitida y llegar a su destino en el silencio. El silencio es como la constante vital que a veces se interrumpe por la palabra"349.

La palabra humana es humanizadora y liberadora del hombre. La familia, la escuela y los medios de comunicación social son lugares donde las palabras deben estar llenas de un contenido liberador. De la misma manera son lugares para la formación o educación de los grandes principios de la vida humana y no para la información. Para Lobato: "La palabra humana está en el origen de la transmisión de la cultura, del aprendizaje, de la capacidad de progreso de todo lo humano" ${ }^{\text {"350. }}$.

Para Lobato: El lenguaje es complejo. Implica un sujeto que habla, un objeto del cual se habla, y un interlocutor a quien se habla. El lenguaje es relación interpersonal por medio de signos que trasmiten algo desde una interioridad ${ }^{351}$. Existe todo un proceso para llegar a la palabra. Hay tres tipos de palabra: de los labios, de la mente, de corazón. Para que sea palabra tiene que ser proferida, salir hacia fuera, del corazón, de la mente de la boca”352. Pero la palabra del corazón es una y necesita muchas de la mente para ser expresada, lo mismo la mente, requiere muchas palabras de la boca para lo que la persona piensa o siente. Así mismo, como lo señala Lobato:

Al hablar el hombre produce un triple verbo, del corazón, de la mente, de la boca. Los dos primeros se verifican en silencio y en la interioridad. Sólo el tercero, el verbum oris rompe el envolvente silencio en que la palabra viene a la luz ${ }^{353}$.

7. La paideia de la verdad. En el camino de ascenso del homo viator y de hacerse hombre es importante la verdad para la vida. Así mismo, hay un deseo natural del hombre por buscar la verdad: "El hombre ha nacido para la verdad y no puede vivir sin ella" ${ }^{354}$. La

\footnotetext{
348 LOBATO, A. "La mujer y el varón cara a cara. El problema de la diferencia". Op. Cit., p. 573.

349 LobATO, A. "El silencio de Dios y el Dios del silencio". Communio (1999), núm. 2., p. 285.

350 LoBATO, A. "La paideia cristiana de la libertad en relación interpersonal". Sophia, Colección de Filosofía de la Educación. 2007, núm. 3, p. 57.

${ }^{351}$ LOBATO, A. "Catequesis y pensamiento contemporáneo". Communio, Vol. 12 (1979), p. 80.

352 Lobato, A. Dignidad y aventura humana. Op. Cit., p. 117.

353 Lobato, A. "El silencio de Dios y el Dios del silencio". Communio, Op. Cit., p. 287.

354 LoBATo, A. Dignidad y aventura humana. Op. Cit., p. 283.
} 
verdad se constituye en una búsqueda y gozo de la misma: "El hombre ama la verdad porque ha nacido para ella, y cuando la encuentra la gusta" ${ }^{355}$.

Según Lobato, en la historia cultural hay tres concepciones originarias de la verdad.

La primera procede de la cultura hebrea, que concibe la verdad como emet, fidelidad; la segunda ha tenido origen en la cultura griega, la verdad es entendida como aletheia, patencia o presencia, la tercera ha conocido su desarrollo en la cultura cristiana medieval cuando la verdad se describe como relación del entendimiento con las cosas y consiste en una adaequastio, conformidad ${ }^{356}$.

De tal manera que cada una de estas concepciones hay un significado de comprensión de la verdad, como lo señala Lobato:

La primera dice relación con el comportamiento ético, la segunda tiene a buscar el fundamento de la verdad en el ente que se presenta al hombre, la tercera pone el lugar de la verdad en el entendimiento en cuanto solo allí donde se da la adecuación se realiza la verdad. ${ }^{357}$

El hombre por naturaleza tiene todas capacidades y facultades para buscar y gozar de la verdad. Como lo indica Lobato: "Por naturaleza el hombre no posee ninguna verdad concreta, pero tiene ya la capacidad de adquirirla: todo hombre nace con un cierto instinto espiritual de la verdad y con lo requerido para acrecentarlo"358. Por consiguiente, el bien del hombre y de la facultad intelectiva es la verdad pero el fundamento de la verdad es el ente: "La verdad tiene su fundamento en el ente como una de sus propiedades" 359 . La inteligencia la que tiene la capacidad de hacer inteligible las cosas o de captar su esencia. Así lo señala Lobato: "La inteligencia es la única que lee dentro, intus-legit, de las cosas, la que de verdad puede preocuparse de ellas, comprenderlas y hablar de ellas" ${ }^{360}$. De ahí que la verdad es formalmente la adecuación de la inteligencia con la verdad y que se verifica en el juicio.

Cuando se falta a la verdad se empobrece la vida humana. Como lo manifiesta Lobato: "La vida intelectual no se nutre de ideas, sino de verdades" ${ }^{\text {361 }}$. El hombre así como construye la

\footnotetext{
${ }^{355}$ LoBATO, A. La paideia exigida por la verdad. En: Robert Christian, O.P. (Eds.). La formazione integrale domenicana. Bologna: 1996, p. 278.

${ }^{356}$ Ibíd. 283

357 Idem.

${ }^{358}$ lbíd., p. 286

359 LOBATO, A. "Tomás de Aquino, modelos de quienes buscan la verdad". Op. Cit., p. 28.

${ }^{360}$ LobAto, A. La verdad como conquista humana. En: Sapientia Aquinatis. Relationes - Communicationes et Acta IV Congressus Thomistici Internationalis. Roma: 1956, p. 209.

${ }^{361}$ LoBATo, A. Dignidad y aventura humana. Op. Cit., p. 108.
} 
verdad o llega a encontrarla después de muchas años y esfuerzo de igual manera la puede destruir y en cuestión de segundo. Para Tomás de Aquino -como para Abelardo-: "Son tres los caminos por los cuales el hombre destruye la verdad: el del pecado, porque quita su verdad a la vida, el error por la cual se aleja de la verdad de la doctrina y el de la injusticia, por el cual la sociedad se corrompe"362.

Además, la verdad es una construcción o búsqueda comunitaria y de la humanidad. De modo que una generación la han recibido de sus predecesores porque ha sido compartida. Es así que, "la verdad es siempre una conquista solidaria, una empresa en común"363. De ahí que debe buscarse porque está esparcida por el mundo y en los sabios. Como lo señala Lobato: "Hay semillas de verdad en todos los pesadores" ${ }^{\text {"364 }}$, y esta convicción se debe seguir el espíritu investigativo de santo Tomás, para quien la verdad venga de donde viniere, siempre procede del Espíritu Santo. De modo que todo inicio de búsqueda de la verdad ya tiene una deuda con el pasado y un compromiso de comunicarla con el futuro. Por consiguiente, hay tres momentos que son la búsqueda de la verdad, el gozo de poseerla y poder comunicarla.

En la búsqueda de la verdad hay un ascenso en el que se parte de las cosas hasta llegar a Dios. Para Lobato en hombre en búsqueda de la verdad: "Aunque tenga que partir de las cosas sensibles en las que hay materia, es capaz de alzarse a la trascendencia y llegar hasta Dios mismo"365. No obstante, la verdad que nos acerca a Dios se ha manifestado en la persona de Jesucristo, de suerte que, "la verdad del ser, la verdad del conocer, y la verdad del vivir se dan en plenitud en Jesucristo" ${ }^{\text {"66 }}$. Así mismo, según Lobato: "La verdad coincide con el ser, del cual es una propiedad, pero está en la mente y viene en definitiva de Dios, y por ello sólo se manifiesta plenamente en Jesucristo, quien dice de sí mismo: Yo soy la verdad (Jn 14, 6)"367.

8. La paideia de la familia. "En el principio era la familia, fruto del amor, fuente del amor humano" ${ }^{368}$. Entre los olvidos de la cultura actual está la familia y es grave porque la familia

\footnotetext{
${ }^{362}$ LoBATO, A. "Tomás de Aquino, modelos de quienes buscan la verdad". Op. Cit., p. 13.

${ }^{363}$ LoBATO, A. Santo Tomás arquitecto de la vida universitaria. El profesor ideal de la paideia tomista. Op.

Cit., p. 33.

${ }^{364}$ Idem., 35

${ }^{365}$ LOBATO, A. "La paideia exigida por la verdad". Op. Cit., p. 282.

${ }^{366}$ Ibíd., p. 280.

${ }^{367}$ LoBATO, A. Santo Tomás arquitecto de la vida universitaria. El profesor ideal de la paideia tomista. Op. Cit., p. 42.

${ }^{368}$ LOBATO, A. "Amor humano y familia cristiana en el alba del siglo XXI". Op. Cit., p. 747.
} 
es fuente de vida y de humanidad, el lugar primordial para hacerse hombre. Como lo recuerda Lobato: "Partimos de un hecho bien patente, ante el cual no es posible dar un rodeo y pasar de largo: el 'olvido' actual de la familia"369. Así mismo, la familia es el lugar primordial y adecuado para la formación y desarrollo integral de la persona o del hacerse hombre.

La familia es el primer lugar donde el hombre encuentra respuestas a las necesidades más humanas como cariño, protección, cuidados, respeto, de ahí que afirmara Lobato: "El hombre es un ser familiar por el simple hecho de que nace, crece, vive y muere en familia” ${ }^{370}$. La condición social se inicia de manera primordial en la familia que a su vez se convierte en núcleo de la vida social: "La sociedad se basa en las personas, y éstas tiene su lugar natural en la familia”371. Entonces: "Por su misma condición humana, antes que ser político o social, el hombre es un ser familiar, tiene su genealogía, padre, madre, hermanos"372. Para Lobato hay cinco notas que por naturaleza conlleva la familia:

\begin{abstract}
Cinco notas lleva por naturaleza la familia: la radical igualdad de personas, varón y mujer cara a cara, imagen de Dios; la insuficiencia recíproca y complementariedad de los sexos: 'no es bueno que el hombre esté solo" (Gn 2,18); la unidad irrompible entre ambos, porque "los dos serán una sola carne' (Gn 2,24); la fecundidad y la duración sin límites, porque está llamados a tener hijos: 'creced y multiplicaos' (Gn 2,28), pues el amor implica la totalidad en el arco de la existencia; y la universalidad, porque afecta a todos los seres humanos en todos los tiempos ${ }^{373}$.
\end{abstract}

Uno de los aspectos fundamentales de la familia es ser lugar de humanización, de formación y promoción de la persona. "La tarea de la familia es formadora, ordenada a la promoción del hombre hasta la plenitud, forjadora de la personalidad"374. Los primeros responsables y formadores de la persona son los padres: "Los padres están llamados a ejercer en la familia la tarea de pedagogos y de escultor"375. A tal punto que: "la tarea de educar a los hijos, que consiste en llevar a la plenitud de lo humano las capacidades que recibe con su naturaleza, es la más propia de los padres" ${ }^{\text {"376 }}$. Así mismo, es fruto del amor,

\footnotetext{
${ }^{369}$ LoBATO, A. "La familia y la Communio Personarum". En: Higinio Marín Pedreño (coord.). Actas Congreso Internacional. Educación, Familia y Vida. Murcia: Universidad Católica San Antonio, 2002, p. 17. 370 Lobato, A. "La familia y la Communio Personarum". En: Higinio Marín Pedreño (coord.). Actas Congreso Internacional. Educación, Familia y Vida. Murcia: Universidad Católica San Antonio, 2002, p. 22. ${ }^{371}$ LoBATO, A. Tomás de Aquino, maestro de maestros. Op. Cit. p. 88.

372 LobATO, A. "La familia y la Communio Personarum". Op. Cit. p. 18

${ }^{373}$ Ibíd., p. 90.

${ }^{374}$ LoBATO, A. Dignidad y aventura humana. Op. Cit., p. 194.

${ }^{375}$ Ibíd., p. 193.

${ }^{376}$ LobATO, A. Tomás de Aquino, maestro de maestros. Op. Cit. p. 91.
} 
de la unión de varón y mujer en orden a la convivencia, la procreación de los hijos y su formación integral. Pues como lo indica Lobato:

El ejercicio de la maternidad y paternidad es constante e irrenunciable en los primeros años de la vida, en la infancia y en la adolescencia. Es en esta época cuando se adquiere la socialización y se educa la libertad del sujeto ${ }^{377}$.

En el hombre el amor es la fuerza creadora y de vida para el desarrollo persona y comunitario. Además el amor humaniza las relaciones interpersonales y la vida recobra un nuevo sentido desde el servicio y la entrega. Como lo señala Lobato: "El ser humano ha nacido para amar. Si no ama no es hombre. Tiene que amar el bien y la verdad, amar a las personas, amar dándose a sí mismo. Esta es su tarea. $Y$ esta tarea es personal”378. Del mismo modo el amor es fundamento de la familia y de la familia del futuro: "La familia vive del amor, y sólo el amor en plenitud puede dar vida a la familia, y por medio de ella lograr los tiempos nuevos" ${ }^{379}$. Más aún: "La familia del futuro tiene que partir de la convicción de que no tiene otra roca más sólida que la del amor" ${ }^{\prime 30}$. De manera que el alimento cotidiano o el pan de cada día de la familia es el amor: "La familia no sólo vive de pan, vive de amor"381.

La familia está compuesta de sujetos personales. La persona por naturaleza está llamada a la relación interpersonal y la familia es el lugar donde las inicia. Sin embargo, a diferencia de otros tipos de relación en otro grupo es que la familia es donde se inicia y debe marcar las demás relaciones y formas de vida grupal. Se trata de una relación de calidad como la describe Lobato: "El mundo de la familia es de la relación sin posesión, desinteresada, de entrega y de servicio, sobre todo de los esposos y de los padres" ${ }^{\text {"32 }}$. Así, la familia adquiere una dimensión trascendental, es decir, icono de Dios. Y lo es en la medida que hay unidad y diferencia de las personas que la componen. Es fundamental la comunión de personas. Al decir de Lobato: "El ser humano se realiza siempre y sólo en la dualidad de los sexos, en la igualdad y la diferencia, en la unidad y la diversidad, en la correlación y reciprocidad” ${ }^{\text {"383. }}$.

\footnotetext{
377 LobAto, A. "La familia y la Communio Personarum". Op. Cit. p. 37.

${ }^{378}$ LoBATO, A. Dignidad y aventura humana. Op. Cit., p. 200.

${ }^{379}$ Ibíd., p. 191.

380 Ibíd., p. 194.

${ }^{381}$ Ibíd., p. 193.

382 Idem.

${ }^{383}$ LOBATO, A. "La paideia cristiana de la libertad en relación interpersonal”. Op. Cit. p. 37.
} 
El hombre en su condición familiar es imagen de Dios en dos sentidos: uno amplio, en cuanto pertenece a la gran familia humana que se extiende a todos los hombre de todos los tiempos, pues todos son creados por la cooperación de los padres y de Dios mismo que infunde el alma en la materia organizada, y otro bien preciso, en cuanto toda familia humana participa de la primera familia, de Adán y Eva, y está ordenada a vivir unida, formando una sola carne para multiplicarse en los hijos. La imagen de Dios creador y vivificador se da de un modo más plano en la familia ${ }^{384}$.

9. La paideia de la cultura. Según Lobato: "La cultura es todo aquello que el hombre añade a su naturaleza, tanto a la humana como a las realidades del contorno humano" ${ }^{385}$. En la tarea de hacerse hombre la cultura es una prolongación de la misma naturaleza humana por la que busca y procura las carencias de su naturaleza. A juzgar por su relevancia, es adaptar el medio en el que se encuentra para su desarrollo personal y comunitario. Como lo señala Lobato:

El hombre es un ser natural que se realiza en la cultura. Hoy hablamos de la cultura en un sentido de totalidad envolvente, de una cierta atmósfera en la cual respira a sus anchas, por cuanto integra los elementos que completa las carencias de su naturaleza ${ }^{386}$.

Las exigencias de la naturaleza humana a las que responde la cultura -según este neotomista- son cinco:

La cultura humana es la respuesta a las cinco exigencias inscritas en la lex naturalis de cada ser humano: la felicidad en la consecución del bien, la conservación del ser, la propagación de la especie por la unión del varón y la mujer, la aspiración a la verdad, la vida en comunión por medo de las relaciones interpersonales ${ }^{387}$.

En consecuencia, la cultura es una respuesta a las necesidades de la naturaleza humana que por sí misma no es suficiente. Así mismo, el hombre es el resultado de lo que ha venido añadiendo y transformando de su naturaleza, y cultivando a lo largo de su historia. Para Lobato, "la cultura se hace por la transformación de lo natural, por la información de la materia" ${ }^{388}$. Además, el mundo creado por el hombre o por la cultura el hombre haya respuesta a su deseos y carencias. Se establece entonces una reciprocidad entre hombre y cultura:

\footnotetext{
${ }^{384}$ LoBATO, A. "La familia y la Communio Personarum". Op. Cit. p. 27.

${ }^{385}$ LobAto, A. "Senderos abiertos hacia el nuevo humanismo". Op. Cit., p. 22.

${ }^{386}$ LOBATO, A. "El horizonte estético del hombre medieval. La perspectiva tomista". Op. Cit., p. 58.

${ }^{387}$ LOBATO, A. "La mujer y el varón cara a cara. El problema de la diferencia". Op. Cit., p. 567.

${ }^{388}$ LoBATO, A. Dignidad y aventura humana. Op. Cit., p. 202.
} 
El hombre es un ser cultural, capaz de construir un mundo a su medida, una nueva biosfera en la cual el hombre encuentra respuesta a sus anhelos y necesidades. La cultura es fruto del hombre y a su vez el hombre es fruto de la cultura ${ }^{389}$.

De manera que la cultura es todo lo que el hombre ha creado y añadido a su naturaleza, una esfera que él mismo va fabricando y envuelve todas las dimensiones humanas. De igual modo lo indica Lobato:

La cultura es la esfera envolvente en que el hombre se mueve. La misma naturaleza le empuja a la creatividad cultural. Cultura no es solo lo que perfecciona a un individuo, no es solo un elemento intelectual. La cultura se entiende ahora como el conjunto de productos que el hombre añade a la naturaleza y que forman la totalidad del mundo en que se sitúa el ser humano ${ }^{390}$.

Así las cosas, la cultura es una dimensión humana. Con todo, un aspecto importante de la cultura es el de promover el desarrollo de la humanidad. $Y$ esto se logra de manera especial a través de los valores y de las virtudes morales, perfeccionando lo humano del hombre. Como lo indica Lobato: "La dimensión cultural tiene una clave de perfección y plenitud de lo humano. Esa clave son los valores de alcance universal" ${ }^{391}$. Al mismo tiempo, es creadora de nueva humanidad para que el hombre sea más hombre: "El auténtico humanismo es el que encuentra su base y su camino ideal en el hombre bueno, virtuoso, que es el que desarrolla la profunda humanidad del hombre ${ }^{392}$.

De ahí que la cultura es ascenso humano por medio del desarrollo de las capacidades humanas: "Hay una cultura que es paideia, educación y promoción del hombre hasta la plenitud virtuosa (...)"393. Pues como lo recalca Lobato: "El hombre es, por su misma condición, un ser ético, porque es libre y está en sus manos hacer el bien y evitar el mal, es principio responsable de sus propios actos" ${ }^{394}$. Pues la cultura es promotora de humanidad y no destructora, como lo puntualiza Lobato: "Ha sido nefasto para la cultura el haberla amputado de la misión más sagrada que era la de forjar hombre maduros en el dominio de sí mismos y en el uso de los conocimientos, que ya ponen un poder en sus manos"395.

\footnotetext{
${ }^{389}$ LOBATO, A. "La paideia cristiana de la libertad en relación interpersonal". Op. Cit., p. 49.

390 LOBATO, A. "La mujer y el varón cara a cara. El problema de la diferencia". Op. Cit., p. 566.

391 LOBATO, A. "La paideia cristiana de la libertad en relación interpersonal". Op. Cit., p 60.

392 LoBATO, A. "Senderos abiertos hacia el nuevo humanismo". Op. Cit., p. 24.

393 LobAto, A. "Maimónides, Averroes y Tomás de Aquino. Diálogo de tres culturas". Communio, Vol. 19 (1986), p. 37.

${ }^{394}$ LOBATO, A. "El sentido moral en situación de peligro en la cultura contemporánea". Angelicum. Vol. 72 (1995), p. 42

${ }^{395}$ LoBATo, A. Santo Tomás de Aquino. Maestro de maestros. Op. Cit., p. 96.
} 


\section{3. 3 El humanismo cristiano como culminación.}

Para Lobato una de las tareas fundamentales del presente siglo es la humanización del hombre. De manera que: "El siglo XXI debe devolver al hombre su auténtico rostro tan desfigurado en el XX. Nos preguntamos cómo lograrlo. Sentimos la fuerza de la invitación y

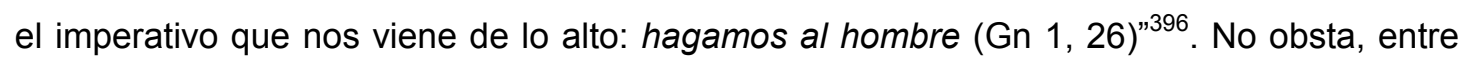
los olvidos de la cultura moderna, denunciar con Lobato el olvido de Dios: "Uno de los fenómenos más preocupantes de nuestra situación cultural es la ausencia, el olvido, el eclipse de Dios"397. De hecho, el olvido de Dios ha afectado la comprensión de la verdad del hombre. Pero el hombre ante Dios encuentra la respuesta integral de lo que es:

Sólo ante Dios, cara a cara, el pequeño absoluto del ser humano, como sujeto que se distiende hacia el infinito, encuentra la respuesta buscada. La verdad definitiva del hombre, $<<$ la verdad toda entera $>>$ tiene que buscarla frente al Absoluto que es Dios. Es ahí donde el hombre obtiene la respuesta que necesita, la que puede dar sentido a su existencia ${ }^{398}$.

El acontecimiento de la Encarnación, de Dios hecho hombre es fundamental para conocer el verdadero rostro de Dios, desfigurado por las diversas y opacas propuestas antropológicas. "Porque Dios se ha hecho hombre, el hombre tiene una nueva vocación filial para ir al encuentro de Dios que lo eleva a la condición de hijo"399. Desde luego, para un mejor conocimiento del hombre la vía de acceso además de la metantropología es la cristología, la persona de Jesucristo, el Hombre en plenitud y el Hombre Nuevo por excelencia. Según Lobato: "La antropología de nuestro tiempo prestará mejores servicio al hombre si se deja enriquecer con las aportaciones de la metantropología y de la cristología" ${ }^{\text {400. }}$.

Jesucristo es el punto de convergencia de la obra divina. Es la vía por la cual todo desciende hasta el hombre y por la cual el todo hombre vuelve a Dios. Desde ese momento para comprender al hombre es preciso penetrar en el misterio de Cristo, y desde Cristo tratar de descifrar el misterio del hombre. El hombre puede decirse centro de la realidad, fin de toda generación, principio antrópico del mundo, pero desde la encarnación es un centro

\footnotetext{
${ }^{396}$ LOBATO, A."El hombre y el misterio de Dios". Op. Cit., 20.

397 LOBATO, A. "El silencio de Dios y el Dios del silencio". Op. Cit., p. 273.

${ }^{398}$ LoBATO, A. "El hombre y el misterio de Dios". Op. Cit., p. 23.

399 LOBATO, A. "El hombre y el misterio de Dios". Op. Cit., 24.

400 LoBATO A. "Antropología y metantropología. Los caminos actuales de acceso al hombre". Op. Cit., p. 41.
} 
$<<$ descentrado >>. El verdadero centro es Cristo, el hombre nuevo. La antropología requiere una mentantropología, y ésta remite a una cristología ${ }^{401}$.

Por consiguiente, el hombre al ser creado a imagen y semejanza de Dios es una criatura teologal. Así mismo, Dios es principio y fin del ser humano. De manera que la pregunta por el hombre y su comprensión de cara a su Creador encuentra la respuesta. Al decir de Lobato: "Sólo frente a Dios el hombre logra su verdad integral. Por su condición espiritual es teotrópico. La dimensión religiosa o teologal da sentido a su origen por creación y a su destino de vida eterna en comunión con Dios" ${ }^{\$ 02}$. Por lo tanto, la dimensión teológica y teologal es central en cuanto encontramos la verdad del hombre en la medida que se relaciona y se acerca a Dios como fundamento antropológico. Según el parecer de Lobato:

Porque ante todo el hombre es un proyecto de Dios, imago Dei, y por ello capax Dei, La relación con Dios es constitutiva en su origen, pues ha sido creado por él, y lo es en su destino, porque está ordenado a Él; lo es en su estructura cognoscitiva porque busca la verdad que sólo en Dios encuentra de modo definitivo; lo es en la esfera volitiva, pues tiende al bien que tiene su fuente en Dios; lo es en su dimensión estética, porque es atraído por la infinita belleza de Dios, participada de mil modo en las creaturas. El nuevo humanismo necesita recorrer este sendero de las relaciones del hombre con Dios $^{403}$.

Dios se acondiciona a la naturaleza del hombre para que pueda conocerlo. Además, Dios es quien toma la iniciativa para el encuentro con el hombre. Como lo puntualiza Lobato: "Las vías que sirven al hombre para el encuentro con Dios deben ser proporcionadas a la naturaleza y ser del hombre, un compuesto de alma y cuerpo y por ello de carne y hueso, de materia y espíritu" 404 . Así mismo, lobatianamente hablando: "Tres son las vías del hombre para el acceso a Dios, en cuanto es objeto de la mente humana allende todo objeto: fe, experiencia y razón" ${ }^{405}$. No obstante, Dios se ha dado a conocer de manera plena en Jesucristo, verdadero Dios y verdadero hombre. Así, Dios ha descubierto su rostro en su Hijo y en Él el verdadero rostro del hombre.

\footnotetext{
${ }^{401}$ LoBATO, A. "El hombre a la luz del misterio de Cristo". En: LOBATO, A (Dir)., y otros. El pensamiento de Santo Tomás de Aquino para el hombre de hoy. Vol. II, El hombre, Jesucristo y la Iglesia. Valencia, España: EDICEP, 2007, p. 34.

${ }^{402}$ LOBATO A. "La verdad integral sobre el hombre: La antropología tomista”. Op. Cit., p. 25.

${ }^{403}$ LOBATO, A. "Senderos abiertos hacia el nuevo humanismo". Op. Cit., p. 7-8.

404 LoBATO, A. "Lo sacro y la religión en Santo Tomás de Aquino". Op. Cit., p. 145.

405 LoBATO, A. "Afirmación de Dios, confirmación del hombre". Op. Cit., p. 5.
} 
El misterio de la Encarnación del Verbo no enseña que Dios desciende hasta el hombre para humanizarse por amor al hombre, para que el hombre recobre su dignidad perdida y conformándose con él ascienda hacia la plenitud de lo humano en una especie de deificación ${ }^{406}$.

De igual modo, la vida de hombre va a consistir en el encuentro con Jesucristo, su relación y configuración con Él por medio de los sacramentos, especialmente del bautismo en el que todo hombre está llamado a un nacer de nuevo o una nueva forma de ser y asumir la vida. "El ser humano está llamado a la transformación en Cristo de un modo tan original y profundo que sin dejar de ser él mismo llega a ser otro" ${ }^{\circ 07}$. El seguimiento de Jesús se constituye para el hombre caminante en camino, verdad y vida. Así mismo y en palabras de Lobato: "Dos misterios caracterizan la fe cristiana, el de la Trinidad y el de la Encarnación. $Y$ en ambos tenemos ya el proyecto hombre, en el primero su origen, en el segundo su realización" ${ }^{408}$.

Inferimos que el hombre además de las facultades humanas y su desarrollo por medio de las virtudes cuenta con el auxilio divino llamado gracia que ayuda en su perfeccionamiento. Como lo señala Lobato: "La gracia es el nuevo principio de ser del cristiano. Un principio que viene de fuera, pero que se infunde para llevar a la perfección la misma naturaleza" ${ }^{\text {"409. }}$. Así mismo con la gracia están las virtudes humanas y cristianas, de modo que: "Si la gracia es el punto de partida, las virtudes son el camino de la transformación cristiana" ${ }^{410}$. Con expresión de Lobato:

La clave de la formación humana está en la conquista y adquisición de las virtudes que no sólo hacen al hombre capaz de la verdad o del dominio del mundo, sino que hacen bueno el acto y forjan al hombre bueno y al buen cristiano. No hay otro camino para la forma de la personalidad humana y cristiana, que el cultivo de las virtudes, morales, teologales, y la docilidad a los dones del Espíritu ${ }^{411}$.

En resumen, la metantropología lobatiana se constituye en punto de partida y fundamento para la comprensión del hombre en la actualidad porque integra los diversos discursos antropológicos. Así mismo, el hombre tiene como tarea el hacerse hombre, homo viator, a través del desarrollo de todas sus facultades y el ejercicio de las virtudes morales. De esta

\footnotetext{
${ }^{406}$ LoBATO, A. "Lo sacro y la religión en Santo Tomás de Aquino". Op. Cit., p. 153.

407 LOBATO, A. "La paideia cristiana de la libertad en relación interpersonal". Op. Cit., p. 64.

408 Lobato, A. Actas del IV Congreso Internacional de la S.I.T.A. Córdoba, España (Tomo I): 1999, p. 301

${ }^{409}$ LOBATO, A. "La paideia cristiana de la libertad en relación interpersonal". Op. Cit., p. 64.

410 lbíd., p. 65.

${ }^{411}$ LoBATO, A. "La Orden de Predicadores y su misión doctrina”. Communio, (2001), Vol. 34, p. 274.
} 
forma el hombre se realiza en las dimensiones $u$ horizontes humanos en las que va ascendiendo en forma de espiral hasta Jesucristo, el hombre nuevo, en el que se revela la imagen de Dios y la verdadera imagen del hombre. Así y todo, el hombre se encuentra a sí mismo de modo radical ante Dios en su Hijo, verdadero Dios y verdadero Hombre. 


\section{CAPÍTULO V}

\section{DESAFÍOS Y RETOS DE LA UNIVERSIDAD DESDE EL HORIZONTE LOBATIANO}

El objetivo del quinto capítulo del presente trabajo de investigación es interpretar la concepción de metantropología como horizonte de conceptualización del humanismo cristiano en la obra de Abelardo Lobato, en el contexto de la Universidad Santo Tomás de Colombia. Para su desarrollo lo dividiremos en los siguientes apartados: 1. La universidad en el pensamiento lobatiano; y 2. La Universidad Santo Tomás en Colombia; 3. 'FACIENTES HUMANITATIS': Hacia un nuevo humanismo en la educación universitaria para el siglo XXI.

\section{1. La universidad en el pensamiento lobatiano}

En el pensamiento lobatiano es fundamental la cultura universitaria para la promoción del humanismo cristiano. Así mismo, para nuestro autor el gran reto de la universidad en el presente y su desafío para el futuro es hacer de la universidad lugar de humanismo o cuna de humanización del hombre. La paideia griega, la humanitas romana y la educación cristiana se han interesado por la formación y humanización del hombre.

De manera que para Lobato la universidad se gesta en el seno de la tradición cristiana. Como él mismo lo indica: "La universidad es una creación de la cristiandad medieval, que ha sido posible gracias a las escuelas de los monasterios y de las catedrales, que ya funcionaban con regularidad en el siglo XII" ${ }^{\text {"12. }}$. Más aún señala: "Ha sido una creación europea, cristiana y medieval ${ }^{\text {413. }}$. Para Lobato la universidad es lugar de humanización del hombre y su misión o finalidad es la búsqueda de la verdad sobre la cual se levanta toda la estructura universitaria. Lobato describió de la siguiente manera la universidad:

La universidad es el lugar adecuado para el desarrollo de la humanidad del hombre, dirigido por su condición de ser inteligente, racional. La racionalidad del ser humano tiene un centro orientador, designado con la palabra verdad. El ser humano ha nacido para la verdad, en su

\footnotetext{
${ }^{412}$ LoBATO, A. Santo Tomás: Arquitecto de la vida universitaria, el profesor ideal de la paideia tomista. p. 17.

${ }^{413}$ Ibíd., p. 19.
} 
estructura radical está conformado para apropiársela intencionalmente y, desde su condición de ser libre, se siente interpelado para dejarse modelar y transformar por ella ${ }^{414}$.

Abelardo Lobato consideraba a la universidad o la escuela como el útero espiritual, una imagen que la toma por una cierta analogía con el útero materno, es decir, un lugar privilegiado de crecimiento, formación integral y humanización del hombre. No obstante, es una imagen universitaria que la retoma del Aquinate. Pues como lo indica él mismo: "Para Tomás la escuela es como el útero espiritual (ST II, II, 10,12), que mantiene una cierta analogía con el útero materno" ${ }^{, 15}$.

Según el filósofo dominicano, la universidad -a la luz del pensamiento tomista-, asume tres quehaceres o tareas específicas e ineludibles al servicio de la humanidad: conservar, vivificar y proyectar. La primera es: "la universidad tiene que ser el lugar de la tradición cultural y de la memoria del pasado" ${ }^{\mathrm{N16}}$. Esta primera tarea implica, grosso modo, tres cosas: en primer lugar, conciencia de la unidad del género humano dentro de un mismo proceso ascendente. Aunque la historia de la humanidad la dividamos y distingamos por etapas o periodos es una sola. $Y$ la universidad juega un papel muy importante en su ascenso y debe evitar que la humanidad decline, decaiga o deshumanice. En segundo lugar, la vigilancia y aprecio por todo lo que han hecho quienes nos han precedido. Pues una generación puede correr el riesgo de destruir en segundos lo que la generación anterior en muchos años ha construido. Efectivamente, una generación se impulsa como el péndulo de la anterior para tomar fuerza y seguir avanzando o ascendiendo. En tercer lugar, en la búsqueda y construcción de la verdad toda la humanidad participa porque es una conquista solidaria y una empresa en común. De manera que la universidad es memoria viva de la humanidad, desde la cual se produce el desarrollo y progreso. De ahí la denuncia profética de Lobato sobre los grandes olvidos de la cultura actual, insertada en la cual ha de desarrollarse en la cultura universitaria una cultura de la memoria. Según Lobato:

La tarea primordial de la universidad consiste en la memoria viviente de la tradición cultural, para acogerla, conservarla y hacerla propia. La racionalidad humana exige una tarea de constante

\footnotetext{
414 Ibíd., p. 32.

${ }^{415}$ Abelardo, haz memoria: Ibíd., p. 325.

416 LobATO, A. "Santo Tomás. Arquitecto de la vida universitaria, el profesor ideal de la paideia tomista". p. 33.
} 
colaboración cultural, de armonía con el pasado del hombre en la conquista de su plena humanidad ${ }^{417}$.

Para nuestro pensador: "La segunda tarea arquitectónica de la universidad está en la trasmisión de la verdad en el presente" ${ }^{418}$. La universidad no guarda el tesoro de la sabiduría sino que lo comparte, no acumula sino que riega el saber. Y la manera de hacerlo es a través del proceso de enseñanza-aprendizaje. En este proceso es como se busca y se construye la verdad, es decir en el diálogo y en la investigación:

Nada hay tan poderoso como la verdad. Hasta Jacob puede discutir con Dios, porque Dios se deja vencer sólo por la fuerza de la verdad. Por ello la tarea universitaria es la de aproximación a la verdad. A la teología se le confía la suprema sabiduría. Pero compete a la razón la búsqueda de la verdad a su alcance, y para ello la universidad tiene que ser el lugar del diálogo y de la investigación $^{419}$.

No obstante, para Abelardo la vida del cristiano oscila entre la verdad revelada que es acogida por la fe y la verdad que se busca, se construye y se demuestra por la fuerza de la razón. En la búsqueda de la verdad se debe tener presente el diálogo, la investigación y el método. La verdad se construye en el diálogo y la controversia (disputatio), ya que no se impone por fuerza de simple autoridad; la investigación beneficia a la enseñanza universitaria porque mejora su calidad; y el método que permite argumentar, distinguir y definir (quaestio), con miras a construir sobre el cimiento de la verdad. De manera que: "La verdad hace al hombre feliz, y la falsedad y el error lo hacen desgraciado" ${ }^{420}$. Insiste Lobato:

Es ahí donde se manifiesta el arquitecto que no edifica sobre opiniones, pareceres, corrientes, sino sobre la roca sólida de la verdad poseída, comunicada, demostrada. En esta perspectiva dialogal la universidad se perfila como una comunidad de investigadores exigentes, de críticos rigurosos, de hombres que necesitan llegar a los principios para dar solidez a lo que enseñan ${ }^{421}$.

Según este neotomista: "La tercera tarea del arquitecto universitario, del oficio del sabio, está orientada hacia el futuro" ${ }^{\text {"22 }}$. La universidad está llamada a proyectar el humanismo del Hombre, el humanismo cristiano: "La universidad está llamada a ser el lugar de la forja integral del hombre, donde se debe hacer posible el futuro más racional de la

\footnotetext{
417 Ibíd., p. 35.

418 Ibíd., p. 36.

419 lbíd., p. 38

${ }^{420}$ Idem.

${ }^{421}$ Ibíd., p. 39.

422 Ibíd., p. 40.
} 
humanidad"423. De manera que para Lobato el futuro del hombre debe ser pensado desde un humanismo cristiano integral en la universidad. Así, para Lobato:

La universidad es una escuela, en su más alto grado, lugar de promoción cultural, del desarrollo del hombre en el encuentro entre maestros y discípulos. Compete a los maestros conducir a sus alumnos hasta llegar a la madurez humana en sus diversas posibilidades de perfección ${ }^{424}$.

Por otra parte, pero en relación con el quehacer de la universidad, de sus retos y desafíos, es importante para Lobato la presencia del maestro, fundamental en la humanización del hombre. De ahí que una de las tareas principales del maestro es la de orientar al alumno hacia la plenitud de la vida humana. Como sabio tomista: "El maestro es un guía en el camino de lo humano, en la conquista de la perfección a la que se siente llamado todo hombre. La universidad realiza su obra a través de sus maestros" ${ }^{\text {"25 }}$. Para Lobato -y en fiel seguimiento de Tomás de Aquino- el maestro es orientador del humanismo:

El maestro ideal en la paideia tomista tiene que ser un maestro al servicio del discípulo, capaz de llevarlo a un desarrollo humano integral, para que pueda contribuir al bien de la sociedad desde el uso adecuado de sus talentos personales ${ }^{426}$.

Además, en la universidad el maestro es un mediador en la conquista personal de la verdad. Así mismo, Lobato llega a afirmar del maestro lo siguiente: "El maestro humano es un auxiliar del alumno, un instrumento a su servicio" ${ }^{427}$. Con estas dos características del maestro, es decir, de auxiliar e instrumento, Lobato define el rol que debe desempeñar en el proceso de enseñanza-aprendizaje, que Tomás había definido como coadyuvante.

El maestro ayuda desde fuera mediante una variedad de elementos para el aprendizaje: los signos, las palabras, los ejemplos que componen la didáctica, partiendo la enseñanza de cosas conocidas por la experiencia en quien aprende. Pues como muy bien lo señala el autor: "Quien aprende es el alumno, y sólo lo hace cuando es capaz de realizar el proceso desde su interior, por sí mismo" ${ }^{428}$.

También el maestro debe caracterizarse por promover las capacidades que el hombre tiene por naturaleza, es decir sus facultades o potencias. Así mismo, para Lobato, en

423 Ibíd., p. 42.

424 Ibíd., p. 43.

${ }^{425}$ Idem.

426 Ibíd., p. 44.

427 Ibíd., p. 45.

${ }^{428}$ Ibíd., p. 46. 
seguimiento de la paideia tomista, el maestro es un orientador y promotor de la formación humanista del hombre. De manera que la formación humana del hombre consiste principalmente en las virtudes. Como lo señala él: "La promoción humana consiste en lograr que el educando adquiera los hábitos dianoéticos, éticos y poiéticos, que son llamadas virtudes intelectuales, morales y técnicas o artísticas, que hacen al sabio, al virtuoso y al genio" 429 .

No obstante, la paideia lobatiana enfatiza la formación moral del hombre, porque recaen sobre el sujeto y lo hacen bueno o virtuoso, es decir, hacen buena la obra y bueno al hombre. Pero en la cultura actual se ha ponderado más en la educación el desarrollo de lo cognitivo y técnico que en lo moral. De modo que con respecto a las virtudes morales -en comparación con las intelectuales y técnicas-, Lobato afirma:

La perfección teórica está en la verdad conocida, la perfección fáctica en la obra realizada. Estas dos actividades indican la capacidad perfectiva del hombre, pero ninguna recae sobre el sujeto y lo hace bueno. En cambio la virtud moral, la prudencia, la justicia, hacen bueno al hombre. Es ella la virtud por antonomasia. Sin ésta no hay plenitud de lo humano ${ }^{430}$.

Más aún, el maestro además de ser docto o sabio en lo que enseña, ha de ser virtuoso, porque enseña la virtud al estudiante con su doctrina y ejemplo de vida. De esta manera la universidad y la formación del hombre en la cultura universitaria conviene que estén al servicio de la sociedad y del Bien Común. En efecto, con relación a la universidad y su servicio a la sociedad, anota Lobato: "La universidad está al servicio de la sociedad. En ella nace, desde ella vive y para ella vive y para ella trabaja. La universidad debe ser espejo de la realidad cultural, tribunal de juicio de su orientación y sus desvíos, instrumento de promoción del Bien Común" ${ }^{\sharp 31}$. De igual manera, el universitario debe ser un profesional competente y al servicio del Bien Común porque de estos talentos y actitudes dependerá la marcha de la sociedad y el ascenso de la humanidad.

\section{2. La Universidad Santo Tomás en Colombia}

La comunidad religiosa Orden de Predicadores (O. P.) o también conocida como dominicos -por su fundador Santo Domingo de Guzmán-, en Colombia han asignado el nombre de Santo Tomás a la Universidad fundada y regentada por los mismos hasta nuestros días. El

\footnotetext{
${ }^{429}$ Ibíd., p. 50.

${ }^{430}$ Ibíd., p. 51

431 Ibid., p. 53.
} 
nombre de la Universidad es, pues, en honor a Tomás de Aquino porque ha sido uno de los pensadores más eximios para la Orden y un hito en el pensamiento de la Iglesia Católica y aun fuera de ella.

El proceso de conformación de la Universidad fue lento hasta su consolidación como hoy día se conoce. Su creación forma parte del carisma dominicano y del espíritu misionero de los primeros frailes dominicos españoles, que arribaron en 1528 a las nuevas tierras encontradas y llamadas el Nuevo Reino de Granada. Muchos de estos frailes de espíritu misionero eran teólogos, filósofos y juristas que habían sido formados en la Escuela de Salamanca y en el seno de la tradición tomista. Entre ellos podemos mencionar a Francisco de Vitoria (1483-1546), Domingo de Soto (1494-1570), Melchor Cano (15091560), Antonio de Montesinos (1475-1540), Bartolomé de las Casas (1484-1566) y san Luis Bertrán (1526-1581).

La presencia histórica de estos primeros frailes dominicos que estuvieron atentos al desarrollo y proceso de evangelización es importante subrayarla por sus contribuciones en la defensa y promoción del hombre amerindio. Además porque en sus predicaciones y escritos subyace el humanismo y la comprensión del hombre a la luz del pensamiento tomista. De la siguiente manera lo indica Lobato:

\footnotetext{
Creo que a ellos les debemos dos contribuciones decisivas en este campo humanizante: ante el hecho de la opresión del hombre por el hombre, han denunciado con acento profético la injusticia y han defendido la dignidad de todo hombre; además han descubierto el principio que hace posible el desarrollo de la promoción integral del hombre en la sociedad. La pasión por la verdad y la justicia les capacita para juzgar con acierto los hechos y la asimilación de la doctrina tomista les prepara para una visión adecuada de los problemas desde la luz de los principios ${ }^{432}$.
}

El compromiso misionero y evangelizador que reflejaron en sus predicaciones y escritos estuvieron acompañadas de una reflexión y comprensión del hombre desde el humanismo cristiano. De manera que cabe recordar el memorable sermón pronunciado por Antonio de Montesinos, cuando en diciembre de 1511, el cuarto domingo de Adviento, subía al púlpito del templo de los dominicos en La Española (Santo Domingo) para denunciar la esclavitud y deshumanización del amerindio durante la conquista: Decid, ¿con qué derecho y con qué

\footnotetext{
432 LoBATO, A. "La aportación de los Dominicos en el S. XVI a la defensa y promoción del hombre". Vol. 70, Angelicum (1993), p. 366.
} 
justicia tienen en tan cruel y horrible servidumbre a estos indios?... ¿Acaso éstos no son hombres?

En el mismo sentido, es importante destacar en estos frailes la comprensión tomista del hombre y del humanismo que desarrollaron desde este contexto histórico porque va a incidir posteriormente en el origen y desarrollo de la misión de la Universidad Santo Tomás de Colombia. Además, la misión principal de los primeros frailes misioneros fue la de fundar convento, predicar y educar. Es así que en nuestros días aún se encuentran sus estructuras físicas conformadas por el convento como lugar de vida comunitaria dominicana, la capilla o parroquia como lugar de predicación y el Colegio o la Universidad como lugar de educación.

La Universidad Santo Tomás fue conocida inicialmente o desde su creación con el nombre de Universidad Tomística, y se constituyó en el 'Primer Claustro Universitario' creado en Colombia. Así mismo, fue aprobada como Universidad mediante el documento o Bula Romanus Pontifex del Papa Gregorio XIII, el 13 de junio de 1580. Sin embargo, su proceso fundacional había comenzado en 1563, y siguió su desarrollo en primer lugar como Colegio-Universidad, hasta que se consolidó como Universidad Tomística en 1639.

El claustro conventual, que se llama así por la construcción cuadrangular que tienen los conventos, es para los frailes dominicos un lugar de vida comunitaria, oración, estudio y apostolado, ideal para vivir el carisma dominicano de la predicación. Además, en el Nuevo Reino de Granada los conventos fueron lugares de evangelización y donde se impartían las primeras lecciones a los hijos de los caciques y de los españoles, por lo cual siguió siendo lugar de evangelización y de educación como lo había sido durante la Edad Media.

De modo que la Universidad Tomística nació en el claustro conventual de Nuestra Señora del Rosario de Santa Fe de Bogotá. Así mismo, los primeros docentes fueron frailes dominicos, pues su presencia en la pastoral docente universitaria hace parte del carisma. Santo Domingo, además de incorporar el estudio al carisma, pidió a los frailes que se fundaran conventos cerca de las universidades.

La pedagogía o formación de la persona en el claustro conventual es una prolongación del modelo de formación medieval. Según Plata, ${ }^{433}$ la formación inicial se basó en el trívium -

\footnotetext{
${ }^{433}$ Cf. PlATA, WILLIAM. En: "La universidad Santo Tomás de Colombia ante su historia: siglos XVI-XIX”. En: Nacimiento del estudio conventual. Bogotá: Universidad Santo Tomás, 2005, p. 83.
} 
conformado por gramática, retórica, dialéctica, y por el cuadrívium, aunque con menos talante, conformado por aritmética, música, geometría, y astronomía. Los estudios superiores fueron fundamentalmente filosofía y teología. Se continuó la lectura de Pedro Lombardo en teología y de Aristóteles en filosofía, pero desde una óptica tomista, es decir, desde los comentarios hechos por Tomás de Aquino a estos pensadores. Poco a poco la lectura de Pedro Lombardo -que duró hasta el año 1551- se remplazará por la lectura directa de la Suma de Teología de Tomás de Aquino. Posteriormente, en el año 1771 se sumará a los estudios de teología la lectura de la obra de fray Melchor Cano, O.P., por un año.

La organización académica conventual se fundamentó en el espíritu de gobierno dominicano. Para Plata ${ }^{434}$, la Orden de Predicadores en Colombia asumió tres tipos de estudios: conventuales, solemnes y generales o universitarios. Los diferentes tipos de estudio tenían en común que estaban orientados por un regente de estudios, un maestro de estudiantes y los lectores que leían públicamente los cursos.

Ahora bien, en los conventos dominicanos, en el Nuevo Reino de Granada, predominó el pensamiento de Tomás de Aquino, cuya enseñanza entre los frailes después de su muerte se había ordenado (1286). No obstante, el tomismo o pensamiento de Tomás se enseñó de manera rutinaria, conservadora y poco creativa, pues se reducía a leer, repetir, comentar y memorizar. Para Cárdenas ${ }^{435}$, no faltaron frailes que con el tiempo y por su formación en el tomismo y su lectura asidua de la obra de Tomás de Aquino, presentaron algunos elementos propios de la formación y pedagogía tomista, como fue el caso de fray Saturnino Gutiérrez Silva, O.P. Los aportes hechos a la comprensión de la pedagogía o formación de la persona -desde Tomás de Aquino- fueron fruto de una fidelidad y creatividad del tomismo; no obstante, su desconocimiento hizo que no prosperara y se perdiera con el tiempo.

Por otra parte, la pedagogía y el modelo de formación del claustro conventual pasó al claustro universitario. Esto se debió a que inicialmente el claustro conventual se convirtió en claustro universitario, no sólo en su estructura sino en su modelo de formación, que seguirá siendo al estilo medieval. De igual manera, el Colegio-Universidad Santo Tomás y

${ }^{434}$ Ibíd., p. 75.

${ }^{435}$ Cf. CÁRdenas Patiño, Alberto. La Universidad Santo Tomas de Colombia ante su historia: Siglos XIXXX: voluntad de persistencia. En: El proyecto educativo del último secretario de la tomística. Bogotá. Universidad Santo Tomás. 2009, p. 168. 
la Tomística seguirán su tradición académica medieval, preocupada por afirmar el tomismo oficial con el que se identificó la Orden de Predicadores y su espíritu universitario.

El movimiento de ideas de la llustración que se había desarrollado en Europa cuando llegaron al nuevo continente, tuvo sus efectos diferentes y contrarios al pensamiento educativo que se había desarrollado en el 'claustro universitario'. Ante las posibles amenazas que representó el pensamiento ilustrado para la Universidad Tomística -según Plata- ${ }^{436}$, se reafirmó la doctrina tomista en la Universidad. Sin embargo, el fenómeno de la Ilustración -ante la poca apertura dialógica de los tomistas- debilitará el tomismo a partir del año 1830, durante la llustración colonial.

La pedagogía ilustrada de Rousseau -y sobre todo de su discípulo Pestalozzi- se fue imponiendo cada vez más como modelo de formación. Al introducirse en el año de 1850 el método de Pestalozzi en la formación de la persona, se trasladará la pedagogía medieval del claustro universitario. Para Cárdenas ${ }^{437}$, dominicos como fray José de Jesús Saavedra, O.P., ya asumían ideas pedagógicas y de formación de la persona más próximas al modelo roussoniano que tomista.

Así las cosas, no dejaron de faltar las propuestas de renovar y defender la doctrina tomista. Sin embargo, en su afán de actualizar y defender el tomismo se intentó poner en diálogo el pensamiento tomista con las corrientes del pensamiento ilustrado, sin obtener ningún resultado satisfactorio. Este renovar y defender el tomismo siguió latente entre los que querían un tomismo puro -llamados tomasianos-, y los que buscan un tomismo dialógico, es decir, poner en diálogo a Tomás y su pensamiento con otras corrientes filosóficas, llamados tomistas.

A todas luces, uno de los elementos fundamentales del pensamiento tomista que se rescató y se incorporó a la formación de la persona fue el humanismo, que renacerá en el Colegio Santo Tomás fundado hasta 1948; durante un largo tiempo fue suprimida o clausurada la Tomística por el gobierno de Tomás Cipriano de Mosquera en 1861, que se prolongó hasta 1965. Cuando el 7 de marzo de 1965 se restauró la Tomística con el nuevo nombre de Universidad Santo Tomás, se resaltó el humanismo cristiano de Tomás de

\footnotetext{
${ }^{436}$ Cf. PLATA, WILLIAM. En. La universidad Santo Tomás de Colombia ante su historia: siglos XVI-XIX. Op.

Cit., p. 217.
${ }_{437}$ Cf. CARDENAS PAtIÑO, Alberto. La Universidad Santo Tomas de Colombia ante su historia: Siglos XIXXX: voluntad de persistencia. Op. Cit., p. 92.
} 
Aquino. Este humanismo cristiano se caracterizaba por ser aplicado, es decir, abierto a los problemas actuales y al diálogo con las distintas formas de pensamiento, como lo indicaba la postura o pensamiento del Aquinate en su obra Suma contra Gentiles y Suma de Teología.

De manera que en el proceso, desarrollo y consolidación de la Universidad Santo Tomás se ha destacado siempre la humanización del hombre. Su origen hay que ubicarlo en los frailes misioneros y pensadores tomistas de la Escuela de Salamanca, que participaron de manera directa o indirecta en defensa y promoción humana del amerindio. La doctrina tomista y el ideal de formación de la Universidad Tomística siempre estuvo amenazada por nuevas ideas y diferentes a las que había desarrollado hasta casi su extinción. Sin embargo, después de su clausura por el presidente del momento y su demorada restauración, renació con ella el humanismo cristiano-tomista que ya se había recuperado en el Colegio Santo Tomás como ideal de formación.

\section{3. La identidad universitaria tomasina}

La Universidad Santo Tomás se inscribe históricamente y se inspira en la amplia y profunda tradición educativa y cultural de la Orden Dominicana, fundada en el siglo XIII, para dedicarse principalmente a la predicación y defensa de la fe cristiana y la enseñanza de la verdad. En la actualidad, como se menciona en el Estatuto Orgánico de la Universidad Santo Tomás:

La Universidad Santo Tomás es una institución de Educación Superior, privada y católica, fundada, restaurada y dirigida por los Frailes de la Orden de Predicadores de la Provincia de San Luis Bertrán de Colombia, con carácter de Fundación, sin ánimo de lucro, de utilidad común, con personería jurídica y autonomía dentro de los límites señalados por la Constitución Política de la República de Colombia, las leyes y el Concordato suscrito entre el Estado Colombiano y la Santa Sede ${ }^{438}$.

Además, la Universidad Santo Tomás, "Primer Claustro Universitario de Colombia", fue la primera institución privada con presencia nacional que recibió la Acreditación Institucional de Alta Calidad Multicampus por parte del Ministerio de Educación Nacional. Efectivamente, mediante Resolución №. 01456 del 29 de enero del 2016, el Ministerio de Educación Nacional otorgó para las sedes de las ciudades de Bogotá, Medellín y Villavicencio, junto con las seccionales en la ciudad de Tunja y Bucaramanga, y los 26

${ }^{438}$ Estatuto Orgánico de la Universidad Santo Tomás. Título primero, art. 2. 
Centros de Atención Universitaria en el territorio nacional, la respectiva Acreditación. Este reconocimiento fue importante porque la Universidad se ubicó entre las primeras universidades que le apuestan por una educación integral y de calidad.

Es así que los elementos que caracterizan a la Universidad Santo Tomás en Colombia están plasmando en sus documentos institucionales -de manera especial en el ya mencionado Estatuto Orgánico de la Universidad Santo Tomás-, el Proyecto Educativo Institucional (PEI), el Modelo Educativo y Pedagógico (MEP), la Política Curricular para Programas Académicos y el Estatuto Docente. Por el momento, nos interesa señalar la misión, visión, el proceso de enseñanza-aprendizaje, así como el humanismo cristiano que definen la filosofía educativa de la Universidad.

De hecho, lo que identifica y distingue a la Universidad lo expresa el Estatuto Orgánico en los siguientes conceptos que plasman su misión:

La Misión de la Universidad Santo Tomás, inspirada en el pensamiento humanista y cristiano de Santo Tomás de Aquino, consiste en promover la formación integral de las personas, en el campo de la Educación Superior, mediante acciones y procesos de enseñanza-aprendizaje, investigación y proyección social, para que respondan de manera ética, creativa y crítica a las exigencias de la vida humana y estén en condiciones de aportar soluciones a la problemática y necesidades de la sociedad y del país ${ }^{439}$.

Ahora bien, entre los componentes de la misión de la Universidad que retoma el Proyecto Educativo Institucional y que resalta están los siguientes:

1. Pensamiento humanista cristiano de Santo Tomás de Aquino ${ }^{440}$. La Universidad se inspira en el pensamiento humanista cristiano de Santo Tomás, por lo tanto tiene una filosofía propia que define su modelo educativo y pedagógico.

2. Promover la formación integral de las personas ${ }^{441}$. La promoción humana es un componente esencial, ya que implica el ascenso de toda persona al estado de la virtud, el desarrollo de todas las facultades y de todas sus dimensiones humanas.

3. Mediante acciones y procesos de enseñanza-aprendizaje, investigación y proyección social $^{442}$. La docencia, la investigación y la proyección social son las tres funciones

\footnotetext{
${ }^{439}$ Ibíd., Cap. 1, art. 7.

${ }_{440}^{44}$ Proyecto Educativo Institucional. Cap. 1. núms. 1.2.3.

${ }^{441}$ Ibíd., núms. 1.2.4.
} 
sustantivas de la Universidad, es decir, las actividades características y fundamentales de la Educación Superior: El docente y el alumno son los sujetos activos del proceso de enseñanza-aprendizaje, la investigación se encamina al aporte y construcción de nuevos saberes en cada área de conocimiento, y la proyección social es una manera de responder de manera asertiva a las necesidades concretas de los otros.

4. Para responder de manera ética, creativa y crítica a las exigencias de la vida humana ${ }^{443}$. El formando tomasino es responsable y corresponsable de su vida y de sus semejantes. Además asume las diferentes situaciones complejas de la humanidad.

5. En condiciones de aportar soluciones a la problemática y necesidades de la sociedad y del país ${ }^{444}$. El profesional tomasino se forma para dar solución a las necesidades e interrogantes de la sociedad y del país; en efecto, se busca que sea un experto en definir problemas dentro de las necesidades comunes.

La Universidad Santo Tomás se proyecta hacia el futuro y este escenario lo pone en evidencia en su visión. De modo que la visión de la Universidad es la siguiente:

En 2027 la Universidad Santo Tomás de Colombia es referente internacional de excelente calidad educativa multicampus, por la articulación eficaz y sistémica de sus funciones sustantivas, y es dinamizadora de la promoción humana y la transformación social responsable, en un ambiente sustentable, de justicia y paz, en procura del Bien Común ${ }^{445}$.

Así, en la visión de la Universidad es preciso resaltar los siguientes aspectos caracterizantes:

1) La promoción humana. El humanismo sigue siendo un tema central en el futuro de la formación de la persona para la Universidad; 2) La trasformación social responsable. El desarrollo social es fundamental para la vivencia y convivencia ciudadanas. Además la corresponsabilidad de los valores sociales e interpersonales de la justicia y la paz. 3) En procura del Bien Común. El interés principal de la nación debe ser el Bien Común por encima de los intereses personales y egoístas, que atentan contra el bien de todos. De manera que la Universidad salvaguardará y estará atenta a cuidar los intereses comunes de la nación.

442 Ibíd., núms. 1.2.6.

443 Ibíd., núms. 1.2.7.

444 Ibíd., núms. 1.2.8.

445 Plan Integral Multicampus. 
Asimismo, la manera como hace realidad la misión y la visión universitarias es a través de la formación de la persona que se plasma en el Modelo Educativo y Pedagógico (MEP). El primero se refiere a los fines y el segundo al proceso de enseñanza-aprendizaje. De manera que la educación, en su sentido teleológico -intencional-, lo entiende la Universidad como un proceso de maduración perfectiva de las facultades del hombre, y como una actualización de sus potencias que desarrolla su naturaleza somática, psíquica y espiritual. De manera que:

"Esta ineludible intencionalidad (teleológica) radica en que el hombre es educable, en cuanto portador de potencias que se pueden encaminar a un máximo desarrollo, y a la realización de su proyecto como ser humano, como persona, en una perspectiva integralm ${ }^{446}$.

En lo referente a la relación pedagógica entre docente y estudiante la Universidad concibe que el rol y la función del maestro no puede ser unilateral autoritaria, ni la actividad del alumno puede concebirse como un activismo protagónico en solitario. De manera que maestro y estudiantes entran en un proceso constructivo del saber a través del diálogo. La Universidad señala el proceso de enseñanza-aprendizaje, entre el maestro y el estudiante de la siguiente manera:

Por ello, la relación profesor-estudiante es dialógica y ninguno de los polos subsume al otro, por lo cual este equilibrio nos libra tanto del predominio absoluto del maestro (modelo tradicionalista) como del populismo pedagógico que pretende hacer del estudiante el primer responsable y único sujeto protagonista de su aprendizaje. Se trata, por tanto, de un realismo pedagógico, que propicia la actividad consciente, responsable y colaborativa del estudiante, su gradual autonomía, sin que ello implique una desaparición o menoscabo del papel también activo del profesor ${ }^{447}$.

De ahí que el Estatuto Docente de la Universidad señale el perfil del maestro tomasino, que debe caracterizarse por su profesionalismo docente e identidad con la filosofía educativa de la institución, y por los fines que persigue en la enseñanza. De manera que la para la Universidad el docente tomasino requiere:

1. Conocimiento de los principios y respeto a la filosofía de la Universidad Santo Tomás, universidad de educación superior, privada y católica. 2 . Sentido de compromiso y consagración a la formación integral de los estudiantes. 3. Respeto, responsabilidad, honestidad y solidaridad con la comunidad académica. 4. Ejercicio ético de su profesión educativa. 5. Interés por la ciencia, la investigación, la docencia y la proyección social de la universidad. 6. Compromiso con el

\footnotetext{
${ }_{446}^{44}$ Modelo Educativo Pedagógico. Cap. 2, núms. 2.5.

447 Ibíd., Cap. 3, núms. 3.3.4.
} 
desarrollo intelectual, espiritual, social y político del país. 7. Búsqueda de la justicia, la paz y el Bien Común ${ }^{448}$.

Desde luego, la filosofía educativa de la Universidad ha sido el humanismo cristiano de Santo Tomás. Es humanista porque el centro de la formación es la persona humana de manera integral y cristiana porque se fundamenta en la persona de Cristo, el Hijo de Dios que asumió la naturaleza humana en el acontecimiento salvífico de la Encarnación. Para Tomás de Aquino el humanismo es teológico porque comprende al hombre desde la mirada o perspectiva teológicas. Además el hombre es creado a imagen y semejanza de Dios por lo que es fundamental destacar la relación del hombre y Dios en la historia de la humanidad, sobre todo en la persona de Jesucristo, verdadero Dios y verdadero hombre, que se constituyó para la humanidad en el Nuevo Hombre y paradigma de todo hombre.

La Universidad Santo Tomás se inspira en el pensamiento humanista cristiano de Santo Tomás de Aquino, construido en el diálogo crítico entre razón y fe, que afirma la dignidad de la persona, fundada en la semejanza con Dios, la necesidad del desarrollo armónico de todas sus potencialidades, al tiempo que enfatiza su dependencia del Creador y su vocación trascendente y social $^{449}$.

Más aún, en consonancia con estos lineamientos, la Universidad Santo Tomás ha creado el Departamento de Humanidades y Formación Integral para el desarrollo de la formación humanística de los estudiantes. Por tanto, el Departamento de Humanidades, inspirado en el humanismo cristiano tomista, pretende dinamizar los procesos de Formación Integral de la comunidad universitaria y aportar elementos para promover una actitud y conciencia críticas, preservando, profundizando y actualizando la misión de la USTA como Universidad de Estudio General en la docencia, la investigación y la proyección social. Esto se concretiza a través de diferentes cátedras que conforman las humanidades como eje trasversal de los diferentes estudios profesionales.

De manera que la principal tarea del Departamento de Humanidades es el énfasis en la formación humanística, y articularla en la formación profesional de los estudiantes tomasinos. Así mismo, los cursos y las cátedras que se imparten para lograr sus objetivos son las siguientes: Epistemología, Filosofía Política, Ética, Cátedras opcionales, Antropología, Cultura teológica, Filosofía institucional, Cátedra Henri Didón, Lectoescritura y Cátedras jurídicas.

${ }^{448}$ Estatuto Docente. Cap. 2, art. 7.

449 Política Curricular para Programas Académicos. Cap. 1, núms. 1.2. 


\section{4. Campos de intersección entre el pensamiento lobatiano y la USTA - Colombia}

Entre la perspectiva lobatiana de universidad y la Universidad Santo Tomás en Colombia existe un campo de intersección que los relaciona y caracteriza lo que es y debe ser la universidad. De modo que la Universidad es lugar de humanización del hombre. En el pensamiento lobatiano el centro de la formación en la universidad es el hombre, quien debe recobrar sentido en este ambiente de formación la expresión bíblica hagamos al hombre (Gn 1:26). Para Abelardo Lobato y la USTA - Colombia la formación del hombre se alcanza por medio del desarrollo de las facultades humanas. Por lo tanto, la universidad debe seguir creando y re-creando el rostro humano del hombre a la luz de la persona de Cristo, quien le revela a la humanidad el verdadero rostro de Dios y el verdadero rostro humano.

En este orden de ideas, el proceso de enseñanza-aprendizaje es fundamental para la construcción del conocimiento humano. Al respecto, un aspecto relevante y enfático de Lobato es la memoria viva en la generación presente de todo lo que se ha edificado en el pasado. Según la misma línea, para la USTA es fundamental la transmisión de los saberes del pasado y se siente responsable de continuar enseñando de manera fiel y a su vez creativa lo que ha recibido. Pero la actitud que se asume es desde la prudencia que mira al pasado, responde a las situaciones concretas del presente y se proyecta hacia el futuro. El maestro y el alumno son los directamente responsables del tesoro del saber que por una parte reciben, comparten y que deben hacer crecer.

Para Abelardo Lobato el diálogo es fundamental en el ascenso histórico de la humanidad. El diálogo es encuentro y acercamiento que se propicia entre épocas, generaciones, culturas y personas. La universidad es el lugar de diálogo para la construcción del saber. Así mismo, la cultura universitaria dialoga con otras culturas y formas de pensar diferente, y asume el diálogo con sus predecesores. Además, entre el maestro y el alumno el diálogo permite el proceso de enseñanza del saber y de su aprendizaje.

Según todos los parámetros anteriores, en la USTA el conocimiento además de enseñarse se construye en diálogo. Así mismo, destaca el papel fundamental que desempeña el maestro en la enseñanza y del alumno en el aprendizaje. Los dos son sujetos activos con una relación horizontal en el que pretende evitar el riesgo de caer en los extremos del 'magistrocentrismo' y el 'paidocentrismo', es decir, el autoritarismo del saber centrado en el maestro y el activismo independiente del alumno sin ninguna guía. 
Ahora bien, la verdad se constituye en otro campo de intersección entre el pensamiento lobatiano y la USTA. Como plus, para este pensador dominicano el sello de identidad de la universidad es la verdad. Además, la verdad es una de las finalidades que busca la universidad y en el proceso de formación de quienes se acercan a ella. De igual manera, para la USTA es fundamental la entrega al trabajo intelectual, al conocimiento profundo y riguroso, al diálogo abierto y al debate filosófico, a la búsqueda de la sabiduría, como lo sintetiza su emblema programático Facientes Veritatem. De manera que la Universidad por vocación y por carisma asume la verdad entre sus principios y finalidades. Así mismo, la verdad que busca y construye en la cultura universitaria apunta hacia Dios como principio y fin sobre el cual se fundamenta toda verdad humana.

A la formación universitaria del Hombre en cuanto Hombre, es decir, libre, autónomo, responsable o dueño de sus propios actos, del hombre en tanto hombre, es decir, dueño de sus actos, no se opone a la formación del hombre profesional. Para Lobato es importante formar al profesional competente al servicio del bien de los que conforman la sociedad. En el mismo sentido, para la USTA el profesional está al servicio de los intereses del Bien Común de la sociedad. Con todo, el profesional se capacita para responder o dar soluciones a los diferentes problemas e interrogantes que se van suscitando en la historia de la humanidad. En efecto, la formación profesional universitaria hace al hombre experto en un área del conocimiento humano, pero al servicio y progreso de la humanidad.

Vistas así las cosas, son muchos los puntos de encuentro que podemos hallar entre la paideia lobatiana sobre la universidad y la formación universitaria con los de la Universidad Santo Tomás de Aquino en Colombia. Los campos de intersección son diversos y, entre otros, resalta la humanización del hombre o del humanismo cristiano, inspirado en el pensamiento de Santo Tomás de Aquino. $Y$ el humanismo tomista es teologal, es decir, comprende al Hombre como un ser creado a imagen y semejanza de Dios. Así mismo, la humanidad y la pregunta por el hombre se responden de cara a Dios en la persona de su Hijo Jesucristo, quien nos revela el verdadero rostro de Dios y del hombre deshumanizado por el pecado.

\section{5. Metodología, análisis y resultados}

Puntualmente, en el marco de la presente investigación se ha procedido a iluminar la cultura universitaria, en el contexto de la Universidad Santo Tomás de Colombia, a la luz del pensamiento lobatiano, de su comprensión metantropológica del hombre como nuevo 
horizonte de comprensión del humanismo cristiano en la Universidad, teniendo muy en cuenta los olvidos que caracterizan a la cultura actual, es decir, el olvido del ser, de Dios, del alma, de la verdad, y del bien. Nos hemos propuesto en esta investigación -con miras a este desarrollo- articular la comprensión del hombre en Lobato con la formación humanística cristiana de la Universidad. El resultado o síntesis de esta articulación entre el pensamiento lobatiano y la cultura universitaria ha de ser una reflexión o una teoría sobre la educación humanista. No obstante, esto exige una metodología que es -en últimas- la teoría fundamentada y el conocimiento del contexto de la Universidad Santo Tomás a través de una encuesta concreta a sus estudiantes.

\section{5.1. Metodología de la teoría fundamentada}

¿Qué tipo de hombre se está formando en la Universidad Santo Tomás en Colombia? Para dar respuesta a esta pregunta fundamental sobre la formación del hombre en el contexto de la cultura universitaria es importante la metodología de la teoría fundamentada. Esta metodología permite articular y comparar la teoría existente -en este caso puntual que nos ocupa de la comprensión del hombre en el pensamiento lobatiano y su relación con el contexto de la formación humanista de la Universidad-, el resultado es la construcción de una nueva teoría. Porque la teoría fundamentada asume como propósito final generar o descubrir una teoría. Este método surge y se fundamenta del proceso de recolección, análisis y sistematización de datos. Entre las técnicas apropiadas privilegiamos la entrevista, la observación y la encuesta.

Ahora bien, en coherencia con esta metodología se ha procedido a la realización de una encuesta a los estudiantes del 'Claustro Universitario' de la Universidad Santo Tomás. Una vez realizada la encuesta se codificaron las categorías-clave y significativas de la cultura y formación humanística, es decir, se realizó una interpretación y análisis de los resultados obtenidos en dichas encuestas. Finalmente, a la luz del pensamiento lobatiano sobre la comprensión metantropológica del hombre se interpretará la formación humanística universitaria en orden al desarrollo de una nueva teoría.

\section{5. 2. Instrumento de investigación}

El instrumento diseñado y empleado en esta investigación lo comprende la encuesta como técnica y el cuestionario como herramienta. Así mismo, el instrumento para la recolección de datos contiene o está conformado por los siguientes puntos: 
I) Datos generales de los participantes; II) La Universidad y la formación humana; III) Las Humanidades, contexto y formación; IV) Sociedad, cultura y persona. Las categorías que componen cada uno de los apartados de la encuesta, se enmarcan o corresponden al contexto universitario y la formación humanística. De igual manera, en cada uno de los puntos se han elaborado diferentes preguntas con selección múltiple a modo de respuestas. Además, se aportó el espacio para que el estudiante tomasino que estudia en la Universidad Santo Tomás pueda escribir y expresar su propia opinión cuando to considere pertinente. Se ha utilizado la herramienta virtual de formularios que contiene Gmial para la realización de la encuesta a nivel nacional. Para tener acceso a ella se utilizó el siguiente correo electrónico: universitatencuesta@gmail.com; password: wilson2017, al ingresar se escogían las aplicaciones de gmail en la aplicación Drive. En ella se encontraban la encuesta y el porcentaje de los resultados.

\section{5. 3. Población}

La población son los estudiantes de la Universidad Santo Tomás, a nivel nacional, de los distintos programas académicos o profesionales, pero que adelantan asignaturas propias del Departamento de Humanidades y Formación Integral de la Universidad. Así mismo, la Universidad Santo Tomás cuenta en el momento con una población estudiantil de 33.508, distribuidos de la siguiente manera: en pregrado 28.906 y en posgrado 4.602. Está conformada por tres Sedes y dos Seccionales: Sede principal de Bogotá, Sede Medellín y Sede Villavicencio, Seccional Tunja y Seccional Bucaramanga. La oferta de programas académicos es la siguiente: 77 pregrados, 111 posgrados, divididos en 67 especializaciones, 40 maestrías y 4 doctorados.

\section{5. 4. Muestra}

La muestra fue la siguiente:

\begin{tabular}{|l|c|}
\hline Sede o Seccional: & Número de encuestados y participantes. \\
\hline Sede principal Bogotá & 496 \\
\hline Sede Medellín & 4 \\
\hline Sede Villavicencio & 2 \\
\hline Seccional Bucaramanga & 0 \\
\hline Seccional Tunja & 6 \\
\hline
\end{tabular}




\section{5. 5. Resultados de las encuestas}

I. Datos generales de los encuestados:

En el primer punto de la encuesta se abordaron los datos generales de los estudiantes participantes. Esto se realizó con el fin de conocer quiénes son los que más participan en cuanto al género, la edad y la facultad.

1. Género. El mayor número de participación en la encuesta estuvo representado por las mujeres. De modo que en total participaron en la encuesta 290 mujeres, muestra equivalente al porcentaje del $57,1 \%$. Mientras tanto, 218 varones participaron en la encuesta, muestra correspondiente al porcentaje del $42,9 \%$. Este dato permitió inferir que entre los estudiantes universitarios, las mujeres son las que más participan y las más comprometidas con los ejercicios de evaluación de la cultura universitaria.

2. Edad. La edad de los universitarios participantes oscila entre los 17 y los 40 años de edad. Sin embargo, la edad de las personas universitarias que más participaron en la encuesta fue una media entre los 19 y 22 años. De modo que participaron 112 estudiantes de 21 años y 110 estudiantes de 20 años de edad. Este dato permitiría pronosticar que el país siempre va a tener profesionales jóvenes en las diferentes áreas de conocimiento que ofrece la Universidad.

3. Facultad. Las facultades que tomaron parte en las encuetas fueron en el orden siguiente: Negocios Internacionales, Mercadeo y Publicidad, Ingeniería Civil, Negocios Internacionales, Ingeniería Industrial, Comunicación Social, Gobierno y Relaciones Internacionales, Derecho, Economía, Administración de Empresas, Psicología, Ingeniería Mecánica, Teología, Sociología, Ingeniería de Sistemas, Contaduría Pública, Ingeniería Ambiental y Cultura Física (18). Es importante desatacar la participación de la Facultad de Ingenierías.

4. Semestre. Los semestres que participaron en la encuesta pertenecían de I-X semestres en las diferentes carreras o facultades de la Universidad. Sin embargo, se observó que hubo mayor participación de $\mathrm{V}$-X semestres.

5. Sede o Seccional. La encuesta se realizó a nivel nacional, es decir, a partir de una muestra poblacional de todas las Sedes y Seccionales donde la Universidad está presente. La Sede universitaria con mayor número de participantes fue la Sede Central Bogotá, con 
496 participantes que equivalía al porcentaje de $97,7 \%$. De la Seccional Tunja participaron 6 estudiantes, que equivalían al porcentaje del 1,2\%. De la Sede Medellín participaron 4 estudiantes, que equivalían al porcentaje del $0,8 \%$. De la Sede de Villavicencio participaron 2 estudiantes, equivalentes al porcentaje del 0,2\%. Finalmente, en la Sede Bucaramanga no participó ningún estudiante en la encuesta.

II. Universidad y formación humana:

La manera como se procedió al análisis de la información adquirida fue en cuatro momentos: 1. Se presentaron las categorías objeto de análisis; 2 . Tabulación general de las respuestas; 3 . Resultados obtenidos; 4. Análisis de las respuestas.

Categoría 1: sobre la universidad y formación humanística. Con respecto a este tópico, se interrogó a los estudiantes encuestados sobre el significado de la universidad como lugar de formación y en particular por la Universidad Santo Tomás de Colombia. El interés sobre esta segunda parte de la encuesta era conocer el significado de cultura y formación universitaria según los estudiantes. Además de la identidad que asumen los estudiantes tomasinos con los principios universitarios y los fundamentos institucionales, se tuvieron en cuenta los intereses personales que persiguen o buscan a través de la formación en la Universidad.

Con respecto a la categoría 1 -sobre "la Universidad y la formación humanística"-, la pregunta No. 1 y los resultados obtenidos fueron los siguientes:

\begin{tabular}{|l|c|l|}
\hline \multicolumn{1}{|l|}{ Pregunta No. 1: Para usted, ¿qué es la Universidad? } \\
\hline Respuestas: & $\begin{array}{l}\text { Número de } \\
\text { estudiantes }\end{array}$ & Promedio \\
\hline a. Un lugar donde se crea conocimiento científico. & 327 & $64,4 \%$ \\
\hline b. Un lugar para la humanización del hombre. & 75 & $14,8 \%$ \\
\hline $\begin{array}{l}\text { c. Una Institución donde se enseñan saberes } \\
\text { especializados. }\end{array}$ & 73 & $14,4 \%$ \\
\hline Otros & 33 & $6,5 \%$ \\
\hline
\end{tabular}

El resultado obtenido de la pregunta No. 1, según las categorías 'Universidad y formación humanística' fue la siguiente: 327 estudiantes, que correspondía al promedio de $64,4 \%$, 
respondió que es "un lugar donde se enseñan saberes especializados". Por otra parte, 75 estudiantes, correspondientes al porcentaje de $14,8 \%$, manifestaron que es "un lugar para la humanización del hombre". Mientras tanto, 73 estudiantes, correspondientes al porcentaje del $14,4 \%$, consideraron que la universidad es "un lugar donde se crea conocimiento científico".

No obstante, en la opción "otros" de la encuesta, 33 estudiantes, equivalentes al porcentaje del 6,5\%, respondieron que la universidad es "un lugar de formación intelectual y humanística". Por ejemplo, el estudiante X escribió lo siguiente: "Un lugar donde se crea conocimiento científico y se enseñan conocimientos especializados, de igual manera es un lugar donde se forman personas humanas en pro de la sociedad" (sic.).

Análisis de la respuesta a la primera pregunta: Según los resultados podemos considerar que en general los estudiantes de la Universidad Santo Tomás, asumen una visión de la universidad como lugar de formación especializada. De manera que la formación profesional impera sobre lo humanístico, que desciende a segundo lugar, y de lo científico que ocupa el tercer lugar de interés. Sin embargo, hay que señalar que algunos estudiantes unen la formación profesional a la humanista.

Con respecto a las categorías 1, sobre "la Universidad y la formación humanística", pregunta número 2 , los resultados fueron los siguientes:

\begin{tabular}{|c|c|c|}
\hline \multicolumn{3}{|c|}{$\begin{array}{l}\text { Pregunta } \mathrm{N}^{\circ} .2 \text { ¿ ¿Conoce usted el modelo educativo y pedagógico de la Universidad } \\
\text { Santo Tomás? }\end{array}$} \\
\hline Respuestas: & Número de estudiantes & Promedio \\
\hline Sí. & 363 & $71,5 \%$ \\
\hline No. & 145 & $28,5 \%$ \\
\hline
\end{tabular}

Los resultados obtenidos de la pregunta No. 2, según las categorías "Universidad y formación humanística" fue la siguiente: 363 estudiantes, equivalentes al porcentaje del $71,5 \%$, respondieron "SÍ. Por otra parte, 145 estudiantes, equivalentes al porcentaje del $28,5 \%$, respondieron "No".

Análisis de la respuesta de la pregunta No. 2: Al parecer la mayoría de los estudiantes tomasinos conocen el modelo educativo y pedagógico de la Universidad (MEP). No obstante, persiste una contradicción entre las respuestas a la primera y segunda pregunta. 
La contradicción que pudimos detectar estribó en lo siguiente: el modelo educativo y pedagógico de la Universidad enfatiza la formación humanista, que conocían todos los estudiantes; sin embargo, optaron por una visión universitaria de tipo o enfoque cognitivo, en su énfasis profesional y científico.

Con respecto a las categorías 1 , sobre "la universidad y la formación humanística", la pregunta No. 3 arrojó los siguientes resultados:

\begin{tabular}{|l|c|l|}
\hline \multicolumn{1}{|c|}{ Pregunta No. 3: ¿Cuál es el fin de la educación en la Universidad Santo Tomás? } \\
\hline \multicolumn{1}{|c|}{ Respuestas: } & Número de estudiantes & Promedio \\
\hline $\begin{array}{l}\text { a. La adquisición de nuevos aprendizajes o } \\
\text { conocimientos. }\end{array}$ & 95 & $18,7 \%$ \\
\hline $\begin{array}{l}\text { b. La conducción y promoción de la persona al } \\
\text { estado perfecto del hombre en cuanto el } \\
\text { Hombre es el estado de virtud. }\end{array}$ & 180 & $35,4 \%$ \\
\hline $\begin{array}{l}\text { c. La educación de los futuros profesionales del } \\
\text { país. }\end{array}$ & 202 & $39,8 \%$ \\
\hline Otros & 31 & $6,1 \%$ \\
\hline
\end{tabular}

El resultado obtenido de la pregunta No. 3, según las categorías "la Universidad y la formación humanística" fue el siguiente: 202 estudiantes, equivalentes al porcentaje del $39,8 \%$, respondieron, entre las diferentes opciones, que la finalidad educativa de la Universidad es: "la educación de los futuros profesionales del país". Por otra lado, 180 estudiantes, que corresponde al promedio de $35,4 \%$, respondieron "la conducción y promoción de la persona al estado perfecto del Hombre en cuanto hombre que es el estado de virtud". Mientras tanto, 95 estudiantes, correspondientes al porcentaje del 18,7\%, respondieron: "la adquisición de nuevos aprendizajes o conocimientos".

Sin embargo, en la opción "otros", respondieron 31 estudiantes, correspondientes al porcentaje del $6,1 \%$; en su mayoría consideraron que el fin de la educación en la Universidad Santo Tomás es la educación de los futuros profesionales con una visión humanista de la sociedad. De esta manera, por ejemplo, el estudiante $\mathrm{X}$, que recogió en su opinión la mayoría de las opiniones, respondió lo siguiente: "La educación de los futuros profesionales pero enfocado también al comportamiento de estos en la sociedad y lo que pueden aportar" (sic.) . 
Análisis de la respuesta de la pregunta No. 3: La prioridad de la Universidad es la formación humanista cristiana de las personas que se incorporan al Claustro Universitario. Sin embargo, la prioridad no quita la importancia fundamental a la formación profesional. Pero la formación profesional debe estar al servicio de la sociedad y del Bien Común o al servicio de la humanidad. Una vez más, la prioridad de los estudiantes tomasinos estuvo enfocada u orientada a lo profesional sobre la formación humanista.

Con respecto a las categorías 1, sobre "la universidad y formación humanística", la pregunta No. 4, los resultados fueron los siguientes:

\begin{tabular}{|l|c|l|}
\hline \multicolumn{2}{|l|}{ Pregunta No. 4: ¿Cuál es el modelo pedagógico de la Universidad Santo Tomás? } \\
\hline \multicolumn{1}{|c|}{ Respuestas: } & Número de estudiantes & Promedio \\
\hline $\begin{array}{l}\text { a. Es 'magistrocentrista', es decir, centrado en la } \\
\text { enseñanza y saberes del maestro. }\end{array}$ & 60 & $11,8 \%$ \\
\hline $\begin{array}{l}\text { b. Es 'paidocentrista', es decir, centrada en } \\
\text { autoaprendizaje del alumno con la compañía } \\
\text { del maestro. }\end{array}$ & 150 & $29,5 \%$ \\
\hline $\begin{array}{l}\text { c. Es un diálogo y proceso en el que se construye } \\
\text { el saber entre el maestro y alumno. }\end{array}$ & 293 & $57,7 \%$ \\
\hline Otros & 5 & $1 \%$ \\
\hline
\end{tabular}

El resultado obtenido de la pregunta No. 4, según las categorías "la Universidad y la formación humanística" es la siguiente: 293 estudiantes, equivalente al porcentaje del $57,7 \%$, respondieron: "es un diálogo y proceso en el que se construye el saber entre el maestro y alumno". Por otro lado, 150 estudiantes, equivalente al porcentaje del $29,5 \%$, respondieron: "es 'paidocentrista', es decir, centrada en autoaprendizaje del alumno con la compañía pasiva del maestro". Mientras tanto, 60 estudiantes, equivalente al porcentaje del $11,8 \%$, consideraron que "es 'magistrocentrista', es decir, centrada en la enseñanza y saberes del maestro, mientras que el alumno es un receptor pasivo".

En la opción "otros", respondieron 5 estudiantes, equivalentes al porcentaje del $1 \%$ de los encuestados, respondieron que el modelo pedagógico es problémico, es decir, se genera una situación problema, teórico o situacional, y sobre ella los estudiantes deben buscar una solución. De esta manera, el estudiante $\mathrm{X}$ respondió lo siguiente: "Es problemática, es 
decir, centrado en el planteamiento de un problema con el fin de progresivamente desarrollar su solución" (sic.)

Análisis de la respuesta de la pregunta No. 4: El modelo pedagógico se refiere al proceso de enseñanza-aprendizaje o a la relación entre el maestro y el estudiante. Es importante resaltar que se trata de un proceso pedagógico en el que los dos, maestro y estudiante, participan activamente. De manera que el saber se construye en un proceso pedagógico entre el estudiante y el alumno tomasino. No obstante, se puede encontrar algunos rasgos del modelo pedagógico paidocentrista y magistrocentrista, en el que sólo tiene una participación activa y central el alumno o el maestro.

Con respecto a la categoría 1, sobre "la universidad y formación humanística", la pregunta No. 5, arrojó los siguientes resultados:

\begin{tabular}{|c|c|c|}
\hline \multicolumn{3}{|c|}{$\begin{array}{l}\text { Pregunta } N^{\circ} .5 \text { : En su opinión, la Universidad del sigo XXI debe educar a las jóvenes } \\
\text { universitarios para: }\end{array}$} \\
\hline Respuestas: & Número de estudiantes & Promedio \\
\hline a. El bien común. & 231 & $45,5 \%$ \\
\hline b. La libertad. & 55 & $10,8 \%$ \\
\hline c. El humanismo. & 195 & $38,4 \%$ \\
\hline Otros & 27 & $5,3 \%$ \\
\hline
\end{tabular}

El resultado obtenido de la pregunta No. 5, según las categorías "la Universidad y la formación humanística” fue el siguiente: 231 estudiantes, equivalentes al porcentaje del $45,5 \%$, respondieron que para "el bien común". Por otra parte, 195 estudiantes, equivalentes al porcentaje del $38,4 \%$, respondieron: "para el humanismo". Mientras tanto, 55 estudiantes, equivalentes al porcentaje del 10,8\%, consideró: "para la libertad". En la opción "otros", 27 estudiantes, equivalentes al porcentaje del 5,3\%, respondieron en su mayoría que para la emancipación y el saber científico.

Cuando se preguntó a los estudiantes las razones o el porqué según las opciones de respuestas dadas o propuestas, escribieron lo siguiente: sobre el Bien Común porque toda persona debe estar al servicio de la comunidad o del bien de todos los que a ella pertenecen. En este sentido, el estudiante $X$ encuestado respondió: "Porque un universitario que se enfoque en el bien común ayudará a la construcción de una mejor sociedad" (sic.) 
Los que optaron por el humanismo argumentaban porque es necesario pensar en el otro. Al respecto, el estudiante $\mathrm{X}$ respondió: "Porque si los jóvenes somos más humanos, vamos a trabajar por el bien común, pensando en el semejante" (sic.) En cuanto a la libertad porque el hombre desarrolla mejor sus capacidades, un estudiante $X$ respondió: "El conocimiento es liberador, y es con este que el hombre se logra desprender de las ataduras de la ignorancia" (sic.).

Análisis de la respuesta de la pregunta No. 5: Además del conflicto armado interno colombiano, la corrupción se ha convertido en el segundo factor que más daño le ha hecho al país para su desarrollo y progreso. De ahí probablemente que muchos estudiantes hayan optado por el Bien Común, pues la falta de honestidad y transparencia en muchos dirigentes del país, evidenciada por los múltiples escándalos de desfalcos financiero ha atentado estructural y sistemáticamente contra el bien de todos los ciudadanos. No obstante, la Universidad enfatiza la formación humanista y profesional al servicio de la sociedad y del Bien Común. De manera que los estudiantes tomasinos sienten el compromiso de trabajar por un mejor país desde su formación profesional.

Con respecto a las categorías 1 , sobre "la universidad y la formación humanística", la pregunta No. 6, arrojó los siguientes resultados:

\begin{tabular}{|c|c|c|}
\hline \multicolumn{3}{|c|}{$\begin{array}{l}\text { Pregunta } \mathrm{N}^{\circ} .6 \text { ¿Los cursos o asignaturas de la línea del Departamento de } \\
\text { Humanidades y Formación Integral le han servido para el proyecto de vida personal y } \\
\text { profesional? }\end{array}$} \\
\hline Respuestas: & Numero de estudiantes & Promedio \\
\hline Sí. & 407 & $80,1 \%$ \\
\hline No. & 101 & $19,9 \%$ \\
\hline qué? & & \\
\hline
\end{tabular}

El resultado obtenido de la pregunta No. 6, según las categorías "la Universidad y la formación humanística" fue el siguiente: 407 de los estudiantes encuestados, equivalentes al porcentaje del 80,1\%, respondió "SÍ". Por otra parte, 101 estudiantes, equivalentes al porcentaje del 19,9\%, respondió "NO". Así mismo, se les preguntó los motivos o el porqué. Como resultado de las respuestas afirmativas, para la mayoría de los estudiantes la razón 
fue porque ayudan a forjar los valores como estudiantes. Al respecto, la estudiante $X$ respondió lo siguiente: "No solo me formo como ingeniera civil sino como persona" (sic.)

Por otra parte, los que respondieron negativamente, consideraron que son materias de "relleno" en cuanto no le aportaron nada de conocimiento al saber profesional que realizan. Por ejemplo, un estudiante $\mathrm{X}$ respondió lo siguiente: "Siento que son materias de relleno que lo que enseñan se puede resumir en una sola cátedra y no casi una por semestre" (sic.)

Análisis de la respuesta No. 6: El Departamento de Humanidades y Formación Integral de la Universidad Santo Tomás tiene la misión de fortalecer en los estudiantes tomasinos la ética profesional para prestar un mejor servicio especializado a los problemas que surgen en contexto. Además se interesa por la formación de personas integrales y profesionales. Sin embargo, es importante seguir articulando las Humanidades en las diferentes áreas o programas académicos que ofrece la Universidad para que el estudiante pueda asimilar la formación humanística en su experiencia de vida práctica.

Con respecto a las categorías 1 , sobre "la universidad y la formación humanística", la pregunta No. 7 arrojó los siguientes resultados:

\begin{tabular}{|c|c|c|}
\hline Respuestas & Número de estudiantes & Promedio \\
\hline Sí. & 494 & $97,2 \%$ \\
\hline No. & 14 & $2,8 \%$ \\
\hline
\end{tabular}

El resultado obtenido de la pregunta No. 7 , según las categorías "la Universidad y la formación humanística" fue el siguiente: 494 estudiantes, equivalentes al porcentaje del $97,2 \%$, respondieron "Sí". Por otra parte, 14 estudiantes, equivalente al porcentaje del $2,8 \%$, respondieron "NO".

Análisis de la respuesta de la pregunta No. 7: Para la Universidad es importante que los estudiantes conozcan que su enfoque humanista es cristiano. Además, que está inspirado en el pensamiento de Santo Tomás de Aquino. De modo que según los resultados obtenidos es preciso destacar el conocimiento que tienen los estudiantes sobre el enfoque humanista cristiano de la Universidad porque crea identidad en los estudiantes con la 
misión universitaria. Sin embargo, urge insistir en la dimensión cristiana porque debe tener como modelo la Persona de Jesucristo.

Con respecto a la categoría 1, sobre "la universidad y formación humanista", la pregunta No. 8 arrojó los siguientes resultados:

\begin{tabular}{|l|c|l|}
\hline \multicolumn{3}{|c|}{ Pregunta No. 8: Para usted, ¿qué significa el concepto humanista cristiano? } \\
\hline \multicolumn{1}{|c|}{ Respuestas: } & Número de estudiantes & Promedio \\
\hline $\begin{array}{l}\text { a. Que todo gira alrededor del hombre, es decir, el } \\
\text { hombre es el centro de todo. }\end{array}$ & 30 & $5,9 \%$ \\
\hline $\begin{array}{l}\text { b. Ascenso o crecimiento del hombre a través } \\
\text { del desarrollo de todas sus facultades con la } \\
\text { ayuda de Dios. }\end{array}$ & 451 & $88,8 \%$ \\
\hline $\begin{array}{l}\text { c. El hombre puede realizarse por sí mismo sin la } \\
\text { ayuda de nadie. }\end{array}$ & 13 & $2,6 \%$ \\
\hline \begin{tabular}{l} 
Otro. \\
\hline
\end{tabular} & 14 & $2,8 \%$ \\
\hline
\end{tabular}

El resultado obtenido de la pregunta No. 8, según las categorías "la Universidad y la formación humanística" fue el siguiente: 451 estudiantes, equivalente al porcentaje del $88,8 \%$ respondieron que es "ascenso o crecimiento del hombre a través del desarrollo de todas sus facultades con la ayuda de Dios". Por otra parte, 30 estudiantes, equivalente al porcentaje del 5,9\%, el humanismo cristiano significa: "que todo gira alrededor del hombre, es decir, el hombre es el centro de todo". Mientras tanto, 13 estudiantes, equivalentes al porcentaje del 2,6\%, opinaron: "el hombre puede realizarse por sí mismo sin la ayuda de nadie". En la opción "otros", 14 estudiantes, equivalentes al porcentaje del 14,8\%, consideraron que el humanismo cristiano significa, un método, la relación del hombre con Dios, ciencia y Dios.

Además, se le preguntó a los estudiantes los motivos o el porqué de las respuestas, y en general fueron la respuesta "b", porque el hombre es un ser religioso y necesita siempre de Dios. El estudiante $X$ respondió lo siguiente: "Dios es el camino la verdad y la vida. De acuerdo a esto él nos guía por el camino adecuado en diferentes aspectos y rumbos que como seres humanos deseamos tomar" (sic.). Para otros estudiantes la respuesta es "a" porque el hombre es el centro de todo. El estudiante $\mathrm{X}$ respondió: "Porque se debe tener disposición propia en el aprendizaje, no todo es obra de Dios" (sic.). Para otro grupo de estudiantes la respuesta fue "c", porque en términos generales, no dependemos de nadie 
para hacer las cosas o tomar decisiones. En este caso la estudiante $\mathrm{X}$ respondió: "Nadie depende de nadie para hacer algo" (sic.).

Análisis de la respuesta de la pregunta No. 8: Los estudiantes tomasinos resaltaron el desarrollo de las potencias humanas, pero al mismo tiempo destacaron la acción de Dios en la vida personal para el crecimiento humano. Se reconoció que existe una cierta ausencia de Dios en un grupo pequeño de estudiantes que se centró más en un tipo de antropocentrismo. Así mismo, se cree en Dios pero ausente de la vida profesional o proyecto de vida. Una vez más conviene resaltar que el humanismo de la Universidad es cristiano, y asume a la persona de Cristo como fundamento.

Con respecto a la categorías 1 sobre "la universidad y la formación humanística", la pregunta No. 9 arrojó los siguientes resultados:

\begin{tabular}{|c|c|c|}
\hline $\begin{array}{l}\text { Pregunta } \mathrm{N}^{\circ} .9 \text { : ¿De qué manera para usted } \\
\text { Universidad? }\end{array}$ & se manifiesta el human & smo en la \\
\hline Respuestas: & Número de estudiantes & Promedio \\
\hline $\begin{array}{l}\text { a. En el respeto hacia la manera de pensar y creer } \\
\text { la otra persona. }\end{array}$ & 411 & $80,9 \%$ \\
\hline $\begin{array}{l}\text { b. En la manera mutua de relacionarse todas las } \\
\text { personas en la universidad sin importar su } \\
\text { creencia, pensamiento, profesión o estrato social. }\end{array}$ & 81 & $15,9 \%$ \\
\hline Otros & 16 & $3,1 \%$ \\
\hline
\end{tabular}

El resultado obtenido de la pregunta No. 9, según las categorías "la Universidad y la formación humanística" fue el siguiente: 411 estudiantes, equivalente al porcentaje del $80,9 \%$, respondió: "en la manera mutua de relacionarse todas las personas en la universidad sin importar su creencia, pensamiento, profesión o estrato social" (sic.). Por otra parte, 81 estudiantes, equivalente al porcentaje del 15,9\%, consideró: "en el respeto hacia la manera de pensar y creer la otra persona" (sic.). En la opción "otros", 8 estudiantes, equivalente al porcentaje del $3,1 \%$, consideraron que se manifiesta en la multiculturalidad de los que hacen parte de la Universidad o del crecimiento intelectual que allí se adquiere. 
Análisis de la respuesta de la pregunta No. 9: Para los estudiantes hay un humanismo que se puede percibir en la Universidad. La manera de percibirse es en el buen trato en las relaciones interpersonales. Además, en las relaciones humanas no se tienen en cuenta el credo religioso, la ideología, la profesión o el estrato social. Igualmente el humanismo se manifiesta en el respeto hacia la manera de pensar y creer de las otras personas. Podemos resaltar un alto grado de convivencia o de relación interpersonal. Sin embargo, no existe una afirmación explícita sobre la persona de Cristo o propiamente del humanismo en perspectiva cristiana.

Con respecto a las categorías 1 , sobre "la universidad y la formación humanística", la pregunta No. 10 arrojó los siguientes resultados:

\begin{tabular}{|c|c|c|}
\hline \multicolumn{3}{|c|}{ Pregunta №. 10: Para usted, ¿qué significa el concepto 'humanismo cristiano'? } \\
\hline Respuestas: & Número de estudiantes & Promedio \\
\hline Sí. & 439 & $86,4 \%$ \\
\hline No. & 69 & $13,6 \%$ \\
\hline
\end{tabular}

El resultado obtenido de la pregunta No. 10, según las categorías "la Universidad y la formación humanística" es la siguiente: 439 personas, equivalentes al porcentaje del $86,4 \%$, respondieron "SÍ". Por otra parte, 69 estudiantes, equivalentes al porcentaje del $13,6 \%$, han respondido "NO".

Análisis de la respuesta de la pregunta No. 10: Para la Universidad es importante resaltar que es humanista y de confesión cristiano-católica porque hacen parte de su identidad institucional. Así mismo, se trata de un cristianismo que por su carácter católico está abierto al diálogo, a recibir y compartir los valores de la cultura humanista. Sin embargo, puede suceder que se tenga conocimiento a nivel teórico del humanismo cristiano sin una experiencia o vivencia y práctica del mismo.

Con respecto a la categorías 1 , sobre "la universidad y la formación humanística", la pregunta No. 11 arrojó los siguientes resultados:

Pregunta №. 11: ¿Qué importancia tiene para usted la confesión cristiana católica de la Universidad Santo Tomás en la formación profesional?

\begin{tabular}{l|l|l|} 
Respuestas: & Numero de estudiantes & Promedio
\end{tabular}




\begin{tabular}{|l|c|l|}
\hline a. Ninguna. & 140 & $27,6 \%$ \\
\hline $\begin{array}{l}\text { b. Hace parte de la formación integral } \\
\text { de la persona. }\end{array}$ & 243 & $47,8 \%$ \\
\hline $\begin{array}{l}\text { c. Para relacionar fe y razón e integrarlas en la } \\
\text { vida personal. }\end{array}$ & 117 & $23 \%$ \\
\hline Otros & 8 & $1,6 \%$ \\
\hline
\end{tabular}

El resultado obtenido de la pregunta No. 11, según las categorías "la Universidad y la formación humanística" fue el siguiente: 140 estudiantes, equivalentes al porcentaje del $27,6 \%$, respondieron: "ninguna". Por otra parte, 243 estudiantes, equivalentes al porcentaje del $47,8 \%$, respondieron: "hace parte de la formación integral de la persona". Mientras tanto, 117 estudiantes, equivalentes al porcentaje del 23\%, respondieron: "para relacionar fe y razón e integrarlas en la vida personal". En la opción de respuesta "otros", 8 estudiantes, correspondientes al porcentaje del $1,6 \%$, consideraron que al conocimiento propio y al diálogo fe y razón, aunque no siempre estén unidas.

Análisis de la respuesta de la pregunta No. 11: Para la Universidad es importante destacar que desde la perspectiva cristiano-católica se promueve la persona en las dimensiones humana y profesional así como en el diálogo entre fe y razón. De manera que es importante resaltar que la confesión cristiano-católica de la Universidad es concebida en los estudiantes tomasinos como promotora de humanidad. Así mismo, la relación entre fe y razón es fundamental en la cultura universitaria, de manera que la Universidad ha inculcado entre los estudiantes la importancia y relación entre fe y razón. No obstante, es preciso considerar que se trata más bien o probablemente de una relación entre vida profesional y religión cristiana o religiosa.

III. Humanidades, contexto y formación

Categoría 2, sobre humanismo cristiano. En la presente categoría se quiere conocer la concepción que forjan los estudiantes tomasinos del humanismo cristiano, e identifica la filosofía educativa de la Universidad Santo Tomás. Además, se trata de determinar los principales olvidos -desde la perspectiva lobatiana-, que subyacen en la cultura universitaria. 
Con respecto a la categoría 2, sobre "humanismo cristiano", la pregunta No. 12 arrojó los siguientes resultados:

\begin{tabular}{|c|c|c|}
\hline \multicolumn{3}{|c|}{$\begin{array}{l}\text { Pregunta N. 12: ¿Han sido importante para su formación humana y profesional los } \\
\text { cursos del Departamento de Humanidades y Formación Integral? }\end{array}$} \\
\hline Respuestas: & Número de estudiantes & Promedio \\
\hline Sí. & 406 & $79,9 \%$ \\
\hline No. & 102 & $20,1 \%$ \\
\hline
\end{tabular}

El resultado obtenido de la pregunta No. 12, según la categoría "humanismo cristiano" fue el siguiente: 406 estudiantes, equivalentes al porcentaje del 79,9\%, respondieron "SI'". Por otra parte, 102 estudiantes, equivalentes al porcentaje del 20,1\%, respondieron "NO". Así mismo, se preguntó a los estudiantes tomasinos encuestados los motivos o el porqué de sus respuestas. Los que respondieron afirmativamente resaltaron que han sido importantes los contenidos sobre las Humanidades y los valores humanos que se infunden. Por ejemplo, el estudiante X respondió: "Por su contenido humanista y en valores" (sic.) Los que respondieron negativamente, consideraron que no son importantes porque no tienen ninguna relación con el estudio profesional que están realizando. De esta manera, verbigracia, el estudiante $\mathrm{X}$ respondió: "No tienen mucho sentido para mí" (sic.).

Análisis de la respuesta de la pregunta No. 12: es una pregunta que ya se había formulado aunque de manera diferente con el ánimo de determinar la incidencia que tienen las Humanidades en la Universidad con miras a la formación integral del estudiante tomasino. Los diferentes cursos y materias del área de Humanidades están encaminados a la formación humana de los estudiantes.

Con todo, en la mayoría de los estudiantes universitarios se ha logrado inculcar la importancia que adquieren las Humanidades para la formación integral y la vida profesional. No obstante, se debe seguir articulando más la formación humanística a la formación profesional, pues de lo contrario se considerarán como dos realidades separadas de la formación universitaria. Además, las Humanidades deben evidenciarse en lo cotidiano y en la práctica profesional, y no reducirse a asignaturas sólo teóricas sino aplicadas. De hecho, cuando no se logra articular lo humanístico y lo profesional se convierten las diferentes materias de las Humanidades en algo suelto y ajeno a la vida del universitario, lo que ellos denominan despectivamente como 'relleno' o 'costura'. 
Con respecto a la categoría 2, sobre "humanismo cristiano", la pregunta No. 13 arrojó los siguientes resultados:

\begin{tabular}{|l|c|l|}
\hline \multicolumn{4}{|l|}{ Pregunta No. 13: ¿Profesa usted algún credo o religión? } \\
\hline \multicolumn{1}{|c|}{ Respuestas: } & Número de estudiantes & Promedio \\
\hline Sí. & 358 & $70,5 \%$ \\
\hline No. & 138 & $27,2 \%$ \\
\hline Otros & 12 & $2,4 \%$ \\
\hline
\end{tabular}

El resultado obtenido de la pregunta No. 13, según la categoría "humanismo cristiano" fue el siguiente: 358 estudiantes, equivalentes al porcentaje del $70,5 \%$, respondió que "SÍ". Por otra parte, 138 estudiantes, equivalentes al porcentaje del 27,2\%, respondió "NO". Mientras tanto, en la opción "otros", 12 estudiantes, correspondientes al porcentaje del 2,4\%, manifestaron que no profesan ninguna religión pero creen en Dios, y otros se consideran agnósticos.

Análisis de la respuesta de la pregunta No. 13: Aunque hay un gran número de estudiantes creyentes o abiertos a lo trascendental, no obstante persiste un número considerable de estudiantes que no profesan ningún tipo de credo, por lo tanto se cierran a la experiencia de relación con lo divino. La formación humanística cristiana tiene presente que el hombre es un ser teologal. Además porque lo trascendental hace parte de la formación integral.

Con respecto a la categoría 2, sobre "humanismo cristiano", la pregunta número 14 arrojó los siguientes resultados:

Pregunta $\mathrm{N}^{\circ}$. 11: Para usted, uno de los problemas más graves que afronta el hombre en la cultura actual es:

\begin{tabular}{|l|c|l|}
\hline \multicolumn{1}{|c|}{ Respuestas: } & Número de estudiantes & Promedio \\
\hline a. El olvido de Dios. & 135 & $26,6 \%$ \\
\hline b. La búsqueda del sentido de la vida. & 139 & $27,4 \%$ \\
\hline c. El buscar y decir la verdad. & 46 & $9,1 \%$ \\
\hline d. La práctica de las virtudes humanas. & 148 & $29,1 \%$ \\
\hline Otros. & 40 & $7,9 \%$ \\
\hline ¿Por qué? & & \\
\hline
\end{tabular}


El resultado obtenido de la pregunta No. 14, según la categoría "humanismo cristiano" fue el siguiente: 135 estudiantes, correspondientes al porcentaje del 26,6\%, consideraron que "el olvido de Dios". Por otra parte, 139 estudiantes, equivalentes al porcentaje del 27,4\%, señalaron: "la búsqueda de sentido de la vida". Mientras tanto, 46 estudiantes, equivalentes al porcentaje del 9,1\% respondieron: "el buscar y decir la verdad". Por otro lado, 148 estudiantes, equivalentes al porcentaje del $29,1 \%$, respondieron: "la práctica de las virtudes humanas". En la opción "otros", 40 estudiantes, equivalentes al porcentaje del 7,9\%, respondieron que entre los problemas más graves está: La falta de valores, el olvido de la alteridad, la ambición, el capitalismo, la discriminación, el olvido de la espiritualidad.

Asimismo, se preguntó por las razones o el porqué de las respuestas: algunos adhirieron al ítem "a". Dios sigue siendo una respuesta para las preguntas del hombre, "b". Se ha subvalorado el don de la vida humana, "c". Se hace mucho daño engañando al prójimo, "d". Aspectos fundamentales para la vida social o convivencia ciudadana.

Análisis de la respuesta de la pregunta No. 14: Para los estudiantes tomasinos el problema que más aqueja al hombre de hoy es la práctica de las virtudes humanas. Puede llegar a ser contradictorio porque siempre en sus respuestas apareció el énfasis en lo profesional. En efecto, se manifestó interés por las relaciones interpersonales, por la vida cívica y el Bien Común. Igualmente, en cuanto a la búsqueda de sentido de la vida recalcaron el no saber tomar decisiones fundamentales, el equivocarse en las elecciones que todos los días se están tomando, la falta de referentes sociales o políticos a seguir.

En cuanto al olvido de Dios, se trata más bien de una indiferencia frente al fenómeno religioso. Se cree en Dios o en un Ser supremo, pero no se profesa ningún tipo de credo o religión. Además, se debe a la pérdida de credibilidad en las instituciones religiosas (Iglesia católica). Sobre buscar y decir la verdad, es por el engaño en la vida política que tanto mal le hace al Bien Común, a las falsas promesas de trabajar por el desarrollo y bienestar social.

Con respecto a la categoría 2, sobre "humanismo cristiano", la pregunta número 15 arrojó los siguientes resultados:

Pregunta №. 15: Considera usted que Dios:

\begin{tabular}{|c|l|l|}
\hline Respuestas: & Número de estudiantes & Promedio \\
\hline
\end{tabular}




\begin{tabular}{|l|c|l|}
\hline a. Está presente en la historia de la humanidad. & 407 & $80,1 \% \%$ \\
\hline $\begin{array}{l}\text { b. Solamente en la oración y los sacramentos } \\
\text { de la Iglesia. }\end{array}$ & 30 & $5,9 \%$ \\
\hline c. Está ausente de los acontecimientos humanos. & 31 & $6,1 \%$ \\
\hline Otros. & 40 & $7,9 \%$ \\
\hline
\end{tabular}

El resultado obtenido de la pregunta No. 15, según la categoría "humanismo cristiano" fue el siguiente: 407 estudiantes, equivalentes al porcentaje del $80,1 \%$, consideraron que Dios "está presente en la historia de la humanidad". Por otra parte, 30 estudiantes, equivalentes al porcentaje del 5,9\%, señaló: "solamente en la oración y en los sacramentos de la Iglesia". Mientras tanto, 31 estudiantes, equivalentes al porcentaje del 6,1\%, respondieron: "está ausente de los acontecimientos humanos". Finalmente, en la opción "otros", 40 estudiantes, correspondientes al porcentajes del $7,9 \%$, afirmaron que no existe o se consideraron agnósticos.

Análisis de la respuesta de la pregunta No. 15: Es muy significativo que un gran porcentaje de los estudiantes tomasinos, además de ser religiosos o creyentes, puedan concebir que Dios está presente en la historia de la humanidad. No obstante, algunos estudiantes redujeron la presencia de Dios a espacios y lugares sagrados. Así mismo, para otros estudiantes Dios está ausente de la experiencia de la vida humana. Finalmente, quienes escribieron su opinión personal, creen en Dios pero consideraron que Él está ausente de la historia de la humanidad.

Con respecto a la categoría 2, sobre "humanismo cristiano", la pregunta No. 16 arrojó los siguientes resultados:

Pregunta $\mathrm{N}^{\circ}$. 16: Desde las diferentes asignaturas del Departamento de Humanidades $y$ Formación Integral de la Universidad Santo Tomás, ¿cuál es la mejor comprensión del hombre?

\begin{tabular}{|l|c|l|}
\hline \multicolumn{1}{|c|}{ Respuestas: } & Número de estudiantes & Promedio \\
\hline $\begin{array}{l}\text { a. El hombre es solamente alma, y es lo más } \\
\text { importante. }\end{array}$ & 21 & $4,1 \% \%$ \\
\hline b. El hombre es fundamentalmente corporeidad. & 31 & $6,1 \%$ \\
\hline c. El hombre es una unidad substancial de alma y & 445 & $87,6 \%$ \\
\hline
\end{tabular}




\begin{tabular}{|l|c|l|}
\hline cuerpo. & & \\
\hline Otros. & 11 & $2,2 \%$ \\
\hline
\end{tabular}

El resultado obtenido de la pregunta No. 16, según la categoría "humanismo cristiano" fue el siguiente: 21 estudiantes, equivalentes al porcentaje del $4,1 \%$, respondieron: "el hombre es solamente alma, y es lo más importante". Por otro lado, 31 estudiantes, correspondientes al porcentaje del $6,1 \%$, respondieron: "el hombre es fundamentalmente cuerpo". Mientras tanto, 445 estudiantes, equivalentes al porcentaje del $87,6 \%$, respondieron: "el hombre es una unidad sustancial de cuerpo y alma". En la opción "otros", 11 estudiantes, equivalentes al porcentaje del $4,1 \%$, escribieron en términos generales que el hombre es conciencia o un ser virtuoso.

Análisis de la respuesta de la pregunta No. 16: Para la Universidad es importante que los estudiantes adquieran una visión antropológica del hombre como totalidad. Además porque de esta antropovisión depende la formación integral de la persona. De modo que un gran porcentaje de los estudiantes tomasinos tiene una visión integral del hombre. Sin embargo, se pueden notar vestigios antropológicos dualistas y reduccionistas en los que se resaltó una visión parcializada del hombre.

Con respecto a la categoría 2, sobre "humanismo cristiano", la pregunta No. 17 arrojó los siguientes resultados:

\begin{tabular}{|l|c|l|}
\hline \multicolumn{3}{|c|}{ Pregunta No. 17: En su opinión, el hombre en sus relaciones interpersonales es: } \\
\hline \multicolumn{1}{|c|}{ Respuestas: } & Número de estudiantes & Promedio \\
\hline a. Un ser sociable y político. & 365 & $71,9 \%$ \\
\hline b. 'Un lobo para el hombre'. & 74 & $14,6 \%$ \\
\hline c. Un amigo para el hombre. & 62 & $12,2 \%$ \\
\hline Otros. & 7 & $1,4 \%$ \\
\hline
\end{tabular}

El resultado obtenido de la pregunta No. 17, según la categoría "humanismo cristiano" fue el siguiente: 365 estudiantes, equivalentes al porcentaje del $71,9 \%$, respondieron: "el hombre es un ser sociable y político". Por otra parte, 74 estudiantes, equivalentes al porcentaje del 14,6\%, respondieron: "el hombre es un lobo para el hombre" (Plauto / Thomas Hobbes). Mientras tanto, 62 estudiantes, equivalentes al porcentaje del 12,2\%, 
respondieron: "el hombre es un amigo para el hombre". En la opción, "otros", resaltaron en términos generales que el hombre es un ser sociable pero al mismo tiempo conflictivo.

Análisis de la respuesta de la pregunta No. 17: Para los estudiantes de la Universidad Santo Tomás el hombre se caracteriza por el desarrollo de su dimensión social y política. Así mismo, resaltaron que mediante las relaciones interpersonales el hombre puede hacerle daño a sus semejantes. La amistad es una virtud social que hace falta desarrollarse más probablemente en el contexto universitario y sobre todo social. Por otra parte -y con un participación menos significativa de los estudiantes- se concibe al hombre en sus relaciones interpersonales como un ser social pero capaz de hacer daño a los demás.

Con respecto a la categoría 2, sobre "humanismo cristiano", la pregunta No. 18 arrojó los siguientes resultados:

Pregunta №. 18: La verdad es un valor fundamental en la vida del hombre. En su opinión:

\begin{tabular}{|l|c|l|}
\hline \multicolumn{1}{|c|}{ Respuestas: } & Número de estudiantes & Promedio \\
\hline a. La verdad no existe. & 12 & $2,4 \%$ \\
\hline b. La verdad es relativa. & 226 & $44,5 \%$ \\
\hline c. La verdad se busca y se construye. & 261 & $51,6 \%$ \\
\hline Otros. & 9 & $1,8 \%$ \\
\hline
\end{tabular}

El resultado obtenido de la pregunta No. 18, según la categoría "humanismo cristiano" fue el siguiente: 12 estudiantes, equivalentes al porcentaje del 2,4\%, señalaron: "la verdad no existe". Por otro lado, 226 estudiantes, equivalentes al porcentaje del 44,5\%, respondieron: "la verdad es relativa". Mientras tanto, 261 estudiantes, equivalentes al porcentaje del $51,4 \%$, respondieron: "la verdad se busca y se construye". En la opción de respuesta "otros", 9 estudiantes, equivalentes al porcentaje del 1,8 \%, anotaron: "la verdad es un consenso social y cultura, en el que la mayoría de personas se ponen de acuerdo".

Además, cuando se preguntó el porqué de las respuestas, hubo las siguientes acotaciones: la verdad no existe porque no es única ni absoluta. En este caso, el estudiante $X$ respondió: "porque no existen saberes absolutos" (sic.). La verdad es relativa porque lo que una persona puede concebir por verdadero no lo es para otro. Por ejemplo, el estudiante $X$ respondió: "porque depende de cada situación y perspectiva de quien la dice" (sic.). 
Finalmente, la verdad se busca y se construye porque se da en diferentes personas. El estudiante $\mathrm{X}$ respondió: "Porque la verdad nosotros mismos somos quienes la vamos construyendo, y pues al construirla la vamos buscando. Así que siempre intentamos de hacer lo mejor para que esta se construya de la mejor manera" (sic.).

Análisis de la respuesta de la pregunta No. 18: Los estudiantes de la Universidad Santo Tomás consideraron en su mayoría que la verdad se busca y se construye. Esto muy en consonancia con el lema de la Universidad y lo que busca inculcarle a los estudiantes. No obstante, omitieron en las respuestas las consideraciones del diálogo y Dios en la construcción de la verdad, como se pudo evidenciar en las respuestas dadas. Sin embargo, un número considerable de estudiantes manifestó que la verdad es relativa, es decir, se tiende más a la opinión y al respeto indiscriminado por lo que cada uno piensa y diga respecto de las cosas. Para un número muy mínimo la verdad simplemente no existe.

Con respecto a la categoría 2, sobre "humanismo cristiano", la pregunta No. 19 arrojó los siguientes resultados:

\begin{tabular}{|c|c|c|}
\hline \multicolumn{3}{|c|}{$\begin{array}{l}\text { Pregunta №. 19: Para usted, ¿en qué virtudes el hombre debería ser fundamentalmente } \\
\text { educado? }\end{array}$} \\
\hline Respuestas: & Número de estudiantes & Promedio \\
\hline a. En las virtudes intelectuales. & 71 & $14 \%$ \\
\hline $\begin{array}{l}\text { b. En las virtudes morales de la prudencia, la } \\
\text { justicia, la fortaleza y la templanza. }\end{array}$ & 376 & $74 \%$ \\
\hline c. En las virtudes artísticas o técnicas. & 19 & $3,7 \%$ \\
\hline Otros. & 42 & $8,3 \%$ \\
\hline
\end{tabular}

El resultado obtenido de la pregunta No. 19, según la categoría "humanismo cristiano" fue el siguiente: 71 estudiantes, equivalentes al porcentaje del 14\%, respondieron: "en las virtudes intelectuales". Por otra parte, 376 estudiantes, equivalentes al porcentaje del $74 \%$, consideraron: "en las virtudes cardinales". Mientras tanto, 19 estudiantes, equivale al 3,7\%, señalaron: "en las virtudes artísticas o técnicas". En la opción "otros", 42 estudiantes, equivalentes al porcentaje del $8,3 \%$, señalaron "todas las anteriores" en cuanto conduzcan a la construcción de la propia vida.

Análisis de la respuesta de la pregunta 19: Hay un interés de los estudiantes tomasinos por la formación en las virtudes morales, aquellas que hacen bueno al sujeto y sus actos. 
También existe un número considerable de estudiantes que optaron por una formación netamente intelectual, académica o profesional.

Con respecto a la categoría 2, sobre "humanismo cristiano", la pregunta No. 20 arrojó los siguientes resultados:

Pregunta $\mathrm{N}^{\circ}$. 20: ¿Cuál ha sido el valor central que ha cultivado en el contexto universitario y profesional?

\begin{tabular}{|l|c|l|}
\hline \multicolumn{1}{|c|}{ Respuestas } & $\begin{array}{l}\text { Número de } \\
\text { estudiantes }\end{array}$ & Promedio \\
\hline a. La verdad. & 193 & $38 \%$ \\
\hline b. La libertad. & 152 & $29,9 \%$ \\
\hline c. Justicia. & 123 & $24,2 \%$ \\
\hline Otros. & 40 & $7,9 \%$ \\
\hline
\end{tabular}

El resultado obtenido de la pregunta No. 20, según la categoría "humanismo cristiano" fue el siguiente: 193 estudiantes, equivalentes al porcentaje del 38\%, respondieron: "la verdad". Por otra parte, 152 estudiantes, equivalentes al porcentaje del $29,9 \%$, señalaron que el valor de "la libertad". Mientras tanto, 123 estudiantes, equivalentes al porcentaje del $24,9 \%$, consideraron que la "justicia". En la opción "otros", señalaron reiteradamente que los valores del respeto, la tolerancia y la honestidad.

Análisis de la respuesta de la pregunta No. 20: El valor que más han cultivado los estudiantes tomasinos es "la verdad". Y es muy importante que la hayan señalado en cuanto se relaciona con el lema propio de la Universidad: Facientes Veritatem. Además, está relacionada con la pregunta No. 18, en cuanto la verdad se busca y se construye. Así mismo, el valor de "la libertad" se ha constituido en uno de los valores cultivados por los estudiantes. Y el valor de la justicia. Son importantes los demás valores señalados por el resto de los estudiantes, que están relacionados con la convivencia ciudadana y las virtudes sociales.

\section{SOCIEDAD, PERSONA Y CULTURA}

Categoría 3, sobre dignidad humana. Sobre esta categoría, se le preguntó a los estudiantes tomasinos sobre la concepción de la dignidad de la persona humana. Además, por la manera de relacionarnos con los demás a través de los medios de comunicación. 
Todo hombre o persona es un ser digno, además un ser comunicativo porque es relacional, y una de las maneras de relacionarse es a través de la comunicación que crea encuentro.

Con respecto a la categoría 3, sobre "dignidad humana", la pregunta No. 21 arrojó los siguientes resultados:

\begin{tabular}{|l|c|l|}
\hline \multicolumn{1}{|l|}{ Pregunta $\mathrm{N}^{\circ}$. 21: La dignidad de la persona proviene, en su opinión: } \\
\hline Respuestas: & $\begin{array}{l}\text { Número } \\
\text { estudiantes }\end{array}$ & de \\
\hline a. Por naturaleza, por el hecho de ser persona. & 385 & $75,8 \%$ \\
\hline b. Por ser imagen y semejanza de Dios. & 93 & $18,3 \%$ \\
\hline c. Por los cargos que ocupa y bienes materiales. & 13 & $2,6 \%$ \\
\hline Otros. & 17 & $3,3 \%$ \\
\hline
\end{tabular}

El resultado obtenido de la pregunta No. 21, según la categoría "dignidad humana" es la siguiente: 385 estudiantes, equivale al porcentaje del $75,8 \%$, señalaron que la dignidad del hombre proviene "por naturaleza, por el hecho de ser persona". Por otra parte, 93 estudiantes, equivalentes al porcentaje del 18,3\%, respondieron: "por ser imagen y semejanza de Dios". Mientras tanto, 13 estudiantes, equivalentes al porcentaje del 2,6\%, respondieron: "por los cargos que ocupa y bienes materiales".

Análisis de la respuesta de la pregunta No. 21: Para los estudiantes tomasinos el hombre por ser hombre es un ser digno. Probablemente, indiferente al fenómeno religioso. No obstante, para otros hay un referente y fundamento que es al ser creado 'a imagen semejanza de Dios'. Para otro grupo de estudiantes está muy relacionado con los bienes materiales y cargos públicos que se tienen. En la opción "otros", 13 estudiantes, equivalentes al porcentaje del 2,6\%, escribieron: "es un constructo social", es decir, lo que significa lo crea un grupo de personas y las acciones que las personas realizan constantemente.

Con respecto a la categoría 3, sobre "dignidad humana", la pregunta No. 22 arrojó los siguientes resultados:

Pregunta №. 22: ¿Qué actos considera usted que atentan más en su contexto social con la pérdida de la dignidad humana? 


\begin{tabular}{|l|c|l|}
\hline \multicolumn{1}{|c|}{ Respuestas: } & $\begin{array}{l}\text { Número } \\
\text { estudiantes }\end{array}$ & Promedio \\
\hline a. Las drogas alucinógenas. & 39 & $7,7 \%$ \\
\hline b. El conflicto armado. & 53 & $10,4 \%$ \\
\hline c. La corrupción. & 373 & $73,2 \%$ \\
\hline Otros. & 44 & $8,7 \%$ \\
\hline
\end{tabular}

El resultado obtenido de la pregunta No. 22, según la categoría "dignidad humana" fue el siguiente: 39 estudiantes, equivalentes al porcentaje del 7,7\%, respondieron: "las drogas alucinógenas". Por otro lado, 53 estudiantes, equivalentes al porcentaje del 10,4\%, consideraron: "el conflicto armado". Mientras tanto, 373 estudiantes, equivalentes al porcentaje del 73,2\%, señalaron: "la corrupción". En la opción "otros", 44 estudiantes, correspondientes al porcentaje del 8,7\%, escribieron el individualismo y la intolerancia.

Análisis de la respuesta de la pregunta No. 22: Para los estudiantes tomasinos, entre los diferentes actos que atentan contra la dignidad de la persona en el contexto social y colombiano, está la corrupción. En todos los aspectos de la vida nacional la corrupción ha atentado contra la dignidad humana, sobre todo a nivel político porque ha atentado contra el Bien Común y educativo, porque pocas personas tienen facilidad para acceder a la educación. De ahí el interés de los estudiantes tomasinos por el Bien Común y todos los valores o virtudes sociales para la ciudadanía y la democracia. Así mismo, el conflicto armado interno que por tantos años le ha hecho daño al país pasa a un segundo lugar...

Con respecto a la categoría 3, sobre "dignidad humana", la pregunta No. 23 arrojó los siguientes resultados:

\begin{tabular}{|c|c|c|}
\hline \multicolumn{3}{|c|}{ Pregunta $\mathrm{N}^{\circ}$. 23: En su opinión, ¿cómo se puede definir la familia humana? } \\
\hline Respuestas: & $\begin{array}{l}\text { Número de } \\
\text { estudiantes }\end{array}$ & Promedio \\
\hline a. La unión de hombre y mujer e hijos. & 169 & $33,3 \%$ \\
\hline $\begin{array}{l}\text { b. El conjunto de personas de un mismo sexo e } \\
\text { hijos. }\end{array}$ & 7 & $1,4 \%$ \\
\hline c. Todas las anteriores. & 280 & $55,1 \%$ \\
\hline Otros. & 52 & $10,2 \%$ \\
\hline
\end{tabular}


El resultado obtenido de la pregunta No. 23, según la categoría "dignidad humana" fue el siguiente: 169 estudiantes, equivalentes al porcentaje del 33,3\%, respondieron: "es la unión de hombre y mujer e hijos". Por otra parte, 7 estudiantes, equivalentes al porcentaje del $1,4 \%$, consideraron: "el conjunto de personas de un mismo sexo e hijos". Mientras tanto, 280 estudiantes, equivalente al porcentaje del $55,1 \%$, consideraron: "todas las anteriores". En la opción "otros", que familia es donde están los valores del amor y el respeto.

Análisis de la respuesta de la pregunta No. 23: Para los estudiantes de la Universidad, es importante el concepto de familia tradicional. Por el contrario, para algunos estudiantes tomasinos pueden existir y convivir las diferentes tipologías de familia. Pero la gran mayoría de los estudiantes señalaron que lo más importante en la familia es que haya los valores del respeto y el amor. Esto sería lo que constituye una familia, es decir, los valores en sus relaciones interpersonales y no las personas que la constituyen.

Con respecto a la categoría 3, sobre "dignidad humana", la pregunta No. 24 arrojó los siguientes resultados:

\begin{tabular}{|l|c|l|}
\hline Pregunta No. 24: ¿Qué medio usted utiliza más para comunicarse? \\
\hline \multicolumn{1}{|c|}{ Respuestas: } & $\begin{array}{l}\text { Número } \\
\text { estudiantes }\end{array}$ & de \\
\hline a. Facebook. & 13 & $2,6 \%$ \\
\hline b. El lenguaje humano directo. & 260 & $52,1 \%$ \\
\hline c. Whatsapp. & 196 & $38,6 \%$ \\
\hline Otros. & 39 & $7,7 \%$ \\
\hline
\end{tabular}

El resultado obtenido de la pregunta No. 24, según la categoría "dignidad humana" fue el siguiente: 13 estudiantes, equivalentes al porcentaje del 2,6\%, respondieron: "Facebook". Por otro lado, 260 estudiantes, equivalentes al porcentaje del $52,1 \%$, señalaron: "el lenguaje humano directo". Mientras tanto, 196 estudiantes, equivalentes al porcentaje del $38,6 \%$, respondieron: "whatsapp". En la opción "otros" consideraron que todos los anteriores.

Análisis de la respuesta de la pregunta No. 24: Sin duda que el lenguaje humano sigue siendo el medio más propicio para la comunicación en los estudiantes de la Universidad. Y 
este aspecto es muy importante porque acrecienta las relaciones interpersonales. Entre los medios de comunicación se hace más uso del medio digital whatsapp que del facebook.

Con respecto a la categoría 3, sobre "dignidad humana", la pregunta No. 25 arrojó los siguientes resultados:

\begin{tabular}{|l|c|l|}
\hline \multicolumn{1}{|c|}{ Pregunta No. 25: ¿En qué ámbito social influye más el medio de comunicación elegido? } \\
\hline \multicolumn{1}{|c|}{ Respuestas: } & $\begin{array}{l}\text { Número } \\
\text { estudiantes }\end{array}$ & Promedio \\
\hline a. En el familiar. & 158 & $3,11 \%$ \\
\hline b. En las relaciones de amistad. & 206 & $40,6 \%$ \\
\hline c. En el académico. & 78 & $15,4 \%$ \\
\hline Otros. & 66 & $13 \%$ \\
\hline
\end{tabular}

El resultado obtenido de la pregunta No. 24, según la categoría "humanismo cristiano" fue el siguiente: 158 estudiantes, equivalentes al porcentaje del 3,11\%, respondieron: "en el familiar". Por otra parte, 206 estudiantes, equivalentes al porcentaje del 40,6\%, señalaron: "en las relaciones de amistad". Mientras tanto, 78 estudiantes, equivalentes al porcentaje del $15,4 \%$, señalaron: "en el académico". En la opción "otros", consideraron que todos los anteriores.

Análisis de la respuesta de la pregunta No. 25: En relación con la pregunta No 17 -donde la vida social y política tienen más importancia que las relaciones de amistad-, sucedió que en la comunicación se amplía a las relaciones interpersonales y no queda reducida a espacios pequeños y cerrados. De manera que los estudiantes tomasinos consideraron la vida social y política como dimensiones principales en las relaciones interpersonales del hombre; sin embargo, ellas están constituidas por la comunicación.

\section{5.6. Interpretación y análisis de los resultados}

La interpretación y el análisis de los resultados obtenidos de la encuesta realizada a los estudiantes de la Universidad Santo Tomás de Colombia se realizan en términos generales a partir de la formación humanística cristiana como categoría central. De modo que se ha llegado a las siguientes consideraciones:

1. La formación de los estudiantes de la Universidad Santo Tomás se caracteriza más por ser profesional que humanística. Sin duda que la Universidad descuella por una 
fundamentación teórica sobre el modelo de formación humanística, plasmada en los diferentes documentos Institucionales. No obstante, los estudiantes han priorizado la formación académica profesional y la Universidad ha respondido muy bien a estos intereses académicos de los estudiantes.

2. Existe un interés de los estudiantes tomasinos por lo humanístico. Aunque los estudiantes priorizan lo profesional a lo humanístico, éste no deja de ser importante en su vida personal y de compromiso con los problemas a nivel local y nacional. Sin embargo, puede llegar a tratarse más de un compromiso profesional que propiamente de formación humanística. Es decir, hay garantía de una formación académica de calidad y profesional, pero esto no garantiza que el estudiante sea bueno en sus actos, propio de la virtud y que subyace en la expresión e intencionalidad de una formación humanística e integral. Pues además de formar excelentes profesionales la universidad busca formar buenas personas moralmente.

3. El Departamento de Humanidades y Formación Integral debe articular más la formación humanística y la formación profesional. De hecho, el eje trasversal son las Humanidades en la Universidad. Así mismo, porque el centro de la formación es la persona humana. Esto implica la formación o el desarrollo de todas sus facultades. No obstante, en la Universidad se ha formado más para las competencias profesionales. Además, el Departamento de Humanidades de la Universidad debe seguir resaltando más la importancia que adquiere la formación humanística para el desarrollo integral del estudiante tomasino. Probablemente una de sus debilidades es que sus asignaturas y cátedras sean muy teóricas y no las articulan al saber profesional. Esto tiene como efecto negativo que las Humanidades para muchos estudiantes se convierten en temas o materias de interés cultural, y otras veces sin importancia porque las consideran como no impactantes en la vida personal o profesional.

4. Resaltar más la persona de Cristo, o el humanismo cristiano. El humanismo de la Universidad es cristiano, y éste no puede ser un adorno o añadido -prótesis- de lo humanista, porque lo especifica. Así mismo, lo cristiano relaciona al estudiante universitario con la experiencia religiosa y trascendental. El Departamento de Humanidades debe entonces re-orientar la experiencia religiosa en lo cristocéntrico y reinocéntrico. En verdad, muy poco o casi nada se menciona a la persona de Cristo.

En efecto, desde la metodología de la teoría fundamentada, la formación humana desde el pensamiento lobatiano y el enfoque humanista cristiano de la Universidad Santo Tomás 
deben orientarse hacia el facientes humanitatis, hacer al hombre verdadero Hombre. No obstante, se trata de hacer al hombre teniendo como prototipo a la persona de Cristo, la verdadera imagen del Hombre y de Dios. $Y$ de esta manera responder a la exigencia de la educación del siglo XXI, encaminada hacer el hombre y que responda de manera comprometida, responsable y corresponsablemente a los problemas del hombre y de la sociedad actual.

V. 5. 7. 'FACIENTES HUMANITATIS': Hacia un nuevo humanismo en la educación universitaria para el siglo XXI

La educación ha tenido diferentes fines en todos los tiempos y en las diversas culturas. Así mismo, se encuentran muchas propuestas o modelos para la educación del hombre. No obstante, el centro de la educación sigue siendo el hombre, que está en constante proceso de formación y de transformación. El hombre es, pero al mismo tiempo se hace. Y en la tarea de hacerse hombre la educación ha sido fundamental para la humanización del hombre.

De manera que el nuevo humanismo para la educación del siglo XXI debe ser la del Facientes Humanitatis, es decir, hacer al Hombre plenamente Hombre. Pero se trata de hacer al hombre según Jesucristo, verdadero Dios y verdadero hombre. Se trata de una formación humanística integral a la luz de la persona creada a imagen y semejanza divina. La formación humanística a la luz de Cristo como modelo del nuevo humanismo. Hoy más que nunca, es indispensable retomar el concepto de humanismo y resignificarlo, sobre todo si estamos comprometidos con la tarea educadora y creemos que tiene sentido en la medida que logre sembrar la semilla de la humanización.

\section{La paideia cristiana}

En muchos países cada vez más se sigue tomando conciencia de que para su desarrollo y progreso la clave es la educación. Así mismo, se considera que una de las principales crisis de una educación de calidad es la falta de inversión o de presupuesto por parte de los organismos gubernamentales; esto sucede sobre todo en los países de América Latina. Además de la necesidad urgente de una educación de calidad, los centros educativos abogan por una educación en la ciencia, la tecnología e innovación como claves para el futuro y esperanza sobre todo de los países menos desarrollados. De manera que para Andrés Oppenheimer: 
El déficit de capital humano para la innovación en la región - léase la falta de ingenieros, científicos y técnicos- es dramática. Y el motivo no es ningún secreto: se debe a que la mayoría de los estudiantes universitarios de América Latina se vuelcan a las Humanidades y a las ciencias sociales $^{450}$.

No obstante, esta idea de educación encaminada a la ciencia, la tecnología y la innovación se está imponiendo cada vez más en las instituciones educativas. Además, este modelo educativo está suplantando el papel fundamental o central que la formación humanística había desempeñado hasta el momento en los centros de educación. Para Martha Nussbaum: "En casi todas las naciones del mundo se están erradicando las materias y las carreras relacionadas con las Artes y las Humanidades, tanto a nivel primario y secundario como a nivel terciario y universitario" ${ }^{\prime 451}$.

Las Humanidades han estado siempre presente en los centros educativos. De igual manera la formación humanística ha permeado los diferentes saberes profesionales. Pero en la cultura contemporánea las Humanidades han venido perdiendo su importancia porque se tiende a una educación para la producción en una cultura consumista. De manera que se ha perdido la formación humanística para el desarrollo y ejercicio de la ciudadanía.

En cambio, la preparación para el ejercicio de la ciudadanía durante los años más importantes de la infancia está en muy mal estado a escala mundial. La formación desde el nivel preescolar hasta el $12^{\circ}$ grado sufre las exigencias del mercado global, que traslada el foco de intención a las aptitudes científicas y técnicas hoy concebidas como la clave de la educación ${ }^{452}$.

Abelardo Lobato advierte, desde la perspectiva tomista, sobre el olvido de las virtudes morales que hacen al hombre bueno y buena su obra. A cambio de ellas se ha puesto el énfasis en la sociedad del conocimiento y de la producción intelectual y técnica. De manera que en la sociedad industrial y técnica, donde sólo cuenta la producción y la utilidad, todo hacer que no hace producir utilidades tiende a ser minusvalorado. No obstante, si la innovación es la esperanza para los países latinoamericanos -y si los países desarrollados

\footnotetext{
450 OPPENHEIMER, ANDRÉS. ¡Crear o morir! La esperanza de Latinoamérica y las cinco claves de la innovación. Colombia, Bogotá: Penguin Random House Grupo Editorial, 2015, p. 292.

451 Nussbaum, Martha C. Sin fines de lucro. Por qué la democracia necesita de las Humanidades. Argentina, Buenos Aires: Katz Editores, 2011, p. 20.

${ }^{452}$ Ibíd., p. 177.
} 
son el ejemplo o modelo a seguir-, sucede que para éstos la innovación pone en riesgo el humanismo del hombre. De esta manera:

Si esta tendencia se prolonga, las naciones de todo el mundo en breve producirán generaciones enteras de máquinas utilitarias, en lugar de ciudadanos cabales con la capacidad de pensar por sí mismos, poseer una mirada crítica sobre las tradiciones y comprender la importancia de los logros y los sufrimientos ajenos ${ }^{453}$.

De manera que surgen las siguientes preguntas: ¿Cuál es la prioridad educativa en la cultura contemporánea, la formación humanística o la científica, técnica y la innovación? Es importante resaltar que todo modelo educativo debe conducir a la formación integral de la persona y a promoverla, puesto que la formación humanística tiende hacia la formación del hombre en su totalidad o integridad. Además, siguiendo la enseñanza tomista y lobatiana la formación humana basada en las virtudes humanas hacen al hombre plenamente Hombre, porque lo hacen bueno y sus actos. Así mismo, une o integra en su ser y su hacer las virtudes intelectivas y las técnicas.

A todas luces, la cultura contemporánea necesita formar personas integrales, que por una parte sean capaces de responder por sí mismas, dueñas de sus propios actos, autónomas y libres. Pero, por otra parte, desarrollar las capacidades como ciudadanos del mundo, del mundo globalizado y multicultural. También personas útiles a la sociedad y comprometidas con el Bien Común. El nuevo siglo requiere también personas capaces de resolver problemas y buscar soluciones diferentes para lo que no funciona. De manera que:

Si no insistimos en la importancia fundamental de las Artes y las Humanidades, éstas desaparecerán, porque no sirven para ganar dinero. Sólo sirven para algo mucho más valioso: para fomentar un mundo donde valga la pena vivir, con personas capaces de ver a los otros seres humanos como entidades en sí mismas, merecedoras de respeto y empatía, que tienen sus propios pensamientos y sentimientos, y también con naciones capaces de superar el miedo y la desconfianza en pro de un debate signado por la razón y la compasión ${ }^{454}$.

Ahora bien, la universidad como lugar de formación humana no puede perder el horizonte de las Humanidades. Porque todo centro de educación antes de formar profesionales es formador de la persona, del humanismo del hombre. En efecto, se trata de un enfoque integral del proceso de formación humanística, y éste debe constituir su misión propia,

453 Ibíd., p. 20.

454 lbíd., p. 189. 
orientada al desarrollo de todas las habilidades o facultades para el desarrollo de su personalidad, el reconocimiento del otro, la ciudadanía y el ejercicio democrático.

La paideia cristiana tiene presente que la universidad católica se caracteriza porque es lugar de humanización. Cuando se le preguntó al actual Papa Francisco: ¿qué es lo que hace que una institución sea verdaderamente cristiana?, respondió: "no se puede hablar de educación católica sin hablar de humanidad" ${ }^{455}$. Y, como muy bien lo señala, "porque precisamente la identidad católica es que Dios se ha hecho hombre" ${ }^{456}$. De hecho, la paideia cristiana se fundamenta en el acontecimiento de la Encarnación, en la pedagogía divina en la que Dios se hizo hombre para humanizar al hombre.

El Concilio Vaticano II, en su Declaración Gravissimus Educationis, señaló la importancia central que tiene la educación orientada hacia la promoción humana a nivel personal y social. La paideia cristiana asume el compromiso de: "Promover la perfección integral de la persona humana, en bien de la misma sociedad terrestre y para la edificación de un mundo que esté configurado más humanamente" ${ }^{457}$.

De igual manera, la universidad cristiana tiene la tarea de conocer "los misterios del hombre y del mundo explicándolos a la luz de la Revelación" ${ }^{\text {"458 }}$. La Encarnación es el punto de partida y fundamento para dar razón de nuestra fe pero también del hombre y el mundo. Es así que la universidad no puede perder su horizonte humanístico como principio estructural de la cultura y saber universitario: "En donde la filosofía y la idea de humanidad dejen de ser el principio estructural, la universidad pierde su razón de ser como universitas y reniega al propio tiempo de su vocación y de su misión propia" ${ }^{\text {"45. }}$.

En el contexto de la educación colombiana son diferentes los estudios que se han realizado para orientarla, es decir, para saber cuál es la prioridad de la educación y su finalidad. La primera tarea ha sido la de hacer partícipes de la educación a todos los miembros de la sociedad colombiana, y mejorar las oportunidades de acceso a la educación básica, media y superior.

\footnotetext{
${ }^{455}$ http://www.romereports.com, recuperado 2015/11/23/

$456 \frac{\text { ldem. }}{\text { ldem. }}$

${ }^{457}$ Concilio Vaticano II. Declaración, Gravissimum Educationis, núm. 3.

458 Juan Pablo II. Constitución Apostólica, Ex Corde Ecclesiae, 1991, núm. 4.

459 SCHILlEBEECKX, EdWARD, O. P.. El mundo y la Iglesia. España, Salamanca: Sígueme: 1969, p. 434.
} 
Así mismo, a través de la educación se ha buscado responder a las situaciones y momentos históricos particulares. Por ejemplo, en el marco de conflicto armado colombiano se ha creado el programa Educar para la paz. De manera que la educación colombiana ha estado al servicio y determinada por sus procesos históricos hacia un país cada vez más democrático.

No obstante, para el desarrollo de un país más democrático y participativo las entidades gubernamentales deben seguir apostándole a la educación e invirtiendo en ella. Desde la perspectiva de la formación humanística y en el contexto histórico colombiano, la educación debe estar encaminada a la formación ciudadana, interpelándose: ¿Qué tipo de ciudadano estamos formando o debemos formar? La educación para formar colombianos ha de estar orientada a hacer de las personas en sociedad más tolerantes, democráticas y honestas. Formar en la tolerancia para desterrar el conflicto, formar en la democracia para la participación social y política, y formar en la honestidad para el Bien Común.

Efectivamente, la Universidad Santo Tomás en Colombia, inspirada en el pensamiento humanista y cristiano de Santo Tomás de Aquino asume como horizonte y eje trasversal el humanismo cristiano, que permea todas las diferentes carreras profesionales. La prioridad de la Universidad desde la paideia cristiana es la formación integral de la persona o la formación humanística. De manera que se forma primero a la persona y al profesional que estén al servicio de la sociedad y del Bien Común. La persona humana se constituye en el principio estructural y la razón de ser de todo el quehacer universitario.

Más aún, las tres funciones sustantivas de la universidad, a saber: la enseñanza, la investigación y la proyección social se orientan al desarrollo integral de la persona, pero al mismo tiempo a responder y aportar soluciones a la problemática y necesidades de la sociedad y del país. De modo que, siguiendo los principios rectores de la paideia cristiana y de las necesidades según el contexto de la educación colombiana, le apuesta a formar personas desde el humanismo cristiano integral con compromiso ciudadano.

La educación humanista ha sido fundamental para el proceso de la formación personal y social. En muchos centros de formación institucional a nivel mundial las Humanidades no tienen espacio porque la educación se ha volcado hacia la innovación, lo técnico y lo científico. Sin embargo, en los países que han puesto su confianza en estos nuevos modelos de educación basados más en la producción, el desarrollo y la sostenibilidad de 
un país, se ha tomado conciencia de que lo que se ha ganado en adelantos técnicos, científicos e innovación se ha perdido en humanismo o en crecimiento humano.

De ahí que la paideia cristiana ha sido maestra de humanismo. Pero se trata de un humanismo en perspectiva cristiana o humanismo cristiano, como un plus o 'valor agregado'. Esta perspectiva tiene como fundamento el acontecimiento de la Encarnación, por la que Dios hecho hombre en Jesucristo se convirtió en modelo del nuevo humanismo del hombre, y en el que Cristo es el maestro y ejemplo de humanidad a seguir.

Así las cosas, la educación colombiana tiene que seguir fortaleciendo en las instituciones educativas la formación humanística para la ciudadanía. La Universidad Santo Tomás, desde la paideia cristiana y en su inspiración tomista, busca responder a las necesidades de una formación humana cristiana integral para la convivencia ciudadana y profesional de sus egresados.

2. Pedagogía teológica: "Hagamos al hombre"...

En cada modelo o propuesta de educación subyace una antropología. Por lo cual es necesario el estudio y la reflexión sobre el hombre y la sociedad en el mundo actual con el fin de reformular y repensar la antropología educativa. Además es importante una comprensión antropológica integral en la base de la educación de la persona para el presente siglo, que integre la atomización antropológica en el momento presente. De manera que:

En primer lugar, tenemos que reformular la antropología que se encuentra en la base de nuestra misión de educación del siglo XXI. Se trata de una antropología filosófica que tiene que ser una antropología de la verdad. Una antropología social, es decir, donde se concibe el hombre con sus relaciones y en su modo de existir. Una antropología de la memoria y de la promesa. Una antropología que hace referencia al cosmos y se preocupa por el desarrollo sostenible. $Y$ aún más, una antropología que hace referencia a $\operatorname{Dios}^{460}$.

La primera afirmación y fundamental que debemos hacer del hombre para una comprensión integral es: el hombre sólo se comprende a la luz de Dios. La antropología teológica es una pedagogía teológica en la que Dios crea o forma al hombre: Hagamos al hombre ${ }^{461}$. Más aún, Dios ha creado al hombre -varón y mujer- a imagen de É $\left.\right|^{462}$. De modo

\footnotetext{
${ }^{460}$ Congregación para la educación católica. Educar hoy y mañana, una pasión que se renueva. Instrumentum Laboris. Cap. III.

${ }^{461} \mathrm{Gn} .1,26$.
} 
que el hombre es icono de la Trinidad. Dios habita en él y lo hace sacro. El hombre desde su creación está re-ligado a lo trascendente, es un ser teologal: "La más profunda raíz de la vida humana consiste en ser persona, en ser imagen de Dios, en estar llamado a un diálogo y a una unión real con Dios ${ }^{463}$.

El mal o lo que deshumaniza al hombre ha entrado en la humanidad en el momento de la ausencia de $\operatorname{Dios}^{464}$. Y como lo manifiesta Lobato: "El hombre ensaya su aventura de vivir a solas, desata sus lazos con Dios, proclama su autonomía. El ateísmo surge allí donde Dios se ausenta. El hombre sin Dios es el hombre a-teo" ${ }^{465}$. Es que el eclipse de Dios ha conducido a un eclipse y oscuridad del hombre, a una pérdida de su imagen y semejanza. La cultura contemporánea con sus ideologías ha recreado la ausencia y el olvido de Dios. De manera que: "El pensar contemporáneo, en un primer momento se ha caracterizado, por su ruptura con todo lo que supusiera trascendencia"466.

El hombre, porque es creado a imagen y semejanza de Dios, es también capaz de Dios, es decir, de conocerlo y amarlo. No obstante, ante la ausencia, el silencio y el olvido de Dios en el hombre y la sociedad contemporánea es fundamental predicar la bienaventuranza al homo viator, que se realiza como persona y peregrino hasta el encuentro definitivo con su Creador. Es importante que la humanidad sienta la misma confianza y amor de amistad con las que fue creado, y comprenda que Dios no es el rival del hombre, sino su principio y fundamento.

Por el contrario, Dios es promotor de la naturaleza humana, como muy bien lo consideró el maestro Tomás de Aquino, para quien la gracia no suprime la naturaleza sino que la perfecciona y la diviniza ${ }^{467}$. De manera que: "El hombre es capaz de ateísmo, pero es también capaz de Dios, y esto es lo que hay que mostrar hoy, porque es una gran verdad desconocida" ${ }^{\text {468. }}$. Así mismo, el gran problema del hombre y de nuestro tiempo es haber desterrado a Dios de su vida y de su historia, al considerarlo innecesario para alcanzar sus proyectos o como un oponente de ellos.

\footnotetext{
462 Gn. 1, 27.

${ }^{463}$ LOBATO, Abelardo. "Secularización y ateísmo". Op. Cit., p. 465.

464 Gn. 3, 1-10

465 LOBATO, Abelardo. "Secularización y ateísmo". Op. Cit., p. 454.

466 Lobato, A. "Catequesis y pensamiento contemporáneo". Op. Cit., p. 61.

${ }^{467}$ Cf. Tomás de Aquino. Suma de Teología, I, q. 1, a. 1 ad. 2.

${ }^{468}$ LoBATo, A. "Secularización y ateísmo". Op. Cit., p. 462.
} 
Porque es preciso superar el prejuicio moderno de que Dios es un cierto rival del hombre, cuando no se toma por opresor. Bien al contrario, Dios es el auténtico fundamento de todo lo humano, la garantía de su plenitud. Por ello afirmar a Dios es confirmar al hombre y, por el contrario, negar a Dios es hacer imposible al hombre ${ }^{469}$.

A decir verdad, el olvido de Dios en el mundo contemporáneo ha desfigurado el rostro humano y auténtico por las manos del mismo hombre. El nuevo humanismo a la luz de Dios o de la pedagogía teológica tiene la tarea de recordarle su dignidad creada a Imagen y semejanza de Dios y re-creada en Cristo. Como lo señala Lobato: "EI siglo XXI debe devolverle al hombre su auténtico rostro, tan desfigurado en el siglo XX. Nos preguntamos cómo lograrlo. Sentimos la fuerza de la invitación y del imperativo que nos viene de lo

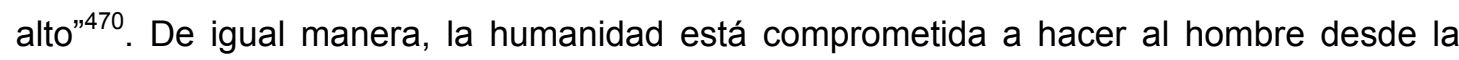
pedagogía divina: "Todo el que tenga oídos atentos a la voz que resuena en su interior, al principio de este milenio, puede oír de nuevo la potente palabra del Creador del hombre, invitándole a esta tarea primordial: Hagamos al hombre (Gen, 1, 26-28),471.

La pedagogía humana es sencillamente una colaboración a la pedagogía de Dios, que promueve integralmente el dinamismo de nuestra auto-realización humana para que asumamos de manera autónoma, libre y responsable nuestra plena realización como personas. Así es como la enseñanza y el acompañamiento de todo pedagogo humano o desde la óptica de Dios, no es sólo permitir que el hombre exista sino que sea en realidad causa consistente y creativa, forjadora de su propia historia. De manera que llevar al discípulo en camino de plenitud, darle su propia densidad de autoafirmación, es dar a Dios su plena gloria.

Referido a nosotros significa que Dios, en virtud de su poder creador, redentor o santificador, no solamente hace que seamos, sin más, efectos pasivos, sino que seamos verdaderamente causas, principios activos, dinamismos en acción. Nuestro vivir es movernos nosotros mismos por nosotros mismos, dueños de nuestros propios actos, para llegar a nuestra perfección, a nuestra plena realización, es decir, a la actuación de todo nuestro riquísimo y complejo potencial que, por lo demás, es un regalo de Dios. El hombre como tal es dueño de sus actos y capaz de caminar hacia este fin por sí mismo.

\footnotetext{
${ }^{469}$ Lobato, A. "Afirmación de Dios, confirmación del hombre”. Op. Cit., p. 30.

470 Lobato, A. "El hombre y el misterio de Dios". Op. Cit., p. 20.

471 Lobato, A. "Senderos abiertos hacia el nuevo humanismo". Op. Cit., p. 2.
} 
Debemos, no obstante, tener en cuenta que un ser puede tender a un fin de dos modos distintos: uno, cuando se mueve a sí mismo hacia el fin, como es el caso del hombre; otro, cuando es otro ser quien lo encamina al fin, como ocurre con la flecha, que se dirige a un fin determinado porque la lanza un arquero, dirigiendo su acción al fin ${ }^{472}$.

La vida humana es don. Todo lo que somos nos viene de Dios como un regalo. Pero al mismo tiempo la vida es tarea. Todo depende de nuestro empeño y de nuestro trabajo. Somos un dinamismo activo; y nuestro destino, por exigencia y a impulso de la gracia de Dios y de nuestra estructura natural, es dar salida a nuestro potencial para realizarnos plenamente, tales como somos y estamos dotados por la gracia y por la naturaleza. El hombre es, en la concepción lobatiana, homo viator, peregrino hacia la conquista de la dignidad, pero también hacia la perfección, la plenitud y la felicidad por sus propios medios humanos y con la gracia de Dios.

Sin embargo, la gracia de Dios, es decir, Dios mismo cuya presencia en nosotros y con nosotros es la primera gracia, no suple nuestro trabajo ni se nos da para llenar los vacíos dejados por nuestra desidia, ni para imponernos una respuesta ya hecha y prefabricada. Por el contrario, potencia y promueve nuestra capacidad para que obremos autónomamente. Más aún potencia y promueve nuestra capacidad de auto-realizarnos, potenciando y promoviendo nuestra capacidad de responder de nosotros mismos por nosotros mismos, sin adherencias umbilicales a nadie, ni a nuestros progenitores, ni a nuestros educadores, ni siquiera a Dios mismo.

Es una sencilla exigencia de crecimiento, de liberación y de madurez, plantada precisamente por la acción de Dios, en el centro mismo de nuestro ser vital; por su parte, Dios nos respeta y promueve nuestra autonomía, respetando y promoviendo su designio. $Y$ viceversa: respeta y promueve su designio, respetando y promoviendo nuestra autonomía. $Y$ todo ello, porque quiere de nosotros, respecto de Él, no una relación de esclavos, sino una relación de personas libres y maduras por convicción y por amor; una comunión, en definitiva, autónoma, gratuita y desinteresada. De manera que reducir o bloquear este proceso autoafirmativo es reducir y bloquear el plan y la acción de Dios: "Luego Dios comunicó a las cosas creadas su bondad de manera que una de ellas pudiese trasfundir a

${ }^{472}$ TOMÁs DE AQUINO. Suma de Teología, I-II, q. 1, a. 2. 
otra lo que recibió. Quitar por lo tanto, sus propias acciones a las cosas es derogar la bondad divina" ${ }^{473}$.

En efecto, es en la familia, la escuela y la universidad, allí donde se forma humanamente al hombre, como en un útero materno, de modo invisible pero real; Dios sigue pronunciando la palabra creadora Hagamos al hombre. Pero Dios ha delegado a la humanidad la responsabilidad de seguir formando al hombre teniendo como modelo a Jesucristo, el nuevo prototipo de Humanidad. De manera que la persona de Jesucristo teje en un mismo horizonte naturaleza y gracia para que el hombre llegue a hacerse plenamente Hombre.

\section{3. "Y el Verbo se hizo carne..."}

El cristianismo asume una forma peculiar de conocer a Dios, porque Dios se nos ha revelado en la persona de su Hijo Jesucristo. La presencia de Dios en nuestro mundo ha sido, y es, una presencia de Encarnación que en Jesús de Nazaret llegó a su punto culminante: "Y el Verbo si hizo carne y habitó entre nosotros" jamás a Dios; el Hijo único, Dios, que estaba al lado del Padre, Él nos lo dio a conocer”775. De manera que los dos grandes misterios que caracterizan la fe cristiana son el de la Trinidad y el de la Encarnación.

A la luz de estos dos grandes misterios de la fe cristiana, se adquiere una nueva comprensión del hombre. Porque en el primero tenemos nuestro origen, el hombre creado a imagen y semejanza de Dios, y en el segundo su realización, Jesucristo, verdadero Dios y verdadero Hombre. Pero esta nueva manera de comprender la antropología es la del proyecto Hombre como un proyecto de Dios que se realiza cabalmente en la persona de Cristo. De modo que el proyecto Hombre es hacer al hombre según la imagen de Dios, y que se plenifica en la persona de su Hijo Jesucristo.

En el misterio del Verbo encontramos la vía de acceso al hombre porque en él la Humanidad asumida alcanza todo la perfección, porque el origen del hombre es trinitario y hunde sus raíces en el misterio de la Encarnación. Más aún, la formación del hombre en la pedagogía de Jesús es circular en tres momentos complementarios: descenso, progreso y ascenso. De manera que la paideia divina es un proceso cristiforme.

\footnotetext{
473 TOMÁs DE AqUINO. Suma contra los Gentiles, lib. III, cap. 69.

474 Jn. 1, 14.

475 Jn. 1, 18.
} 
El descenso de Dios: en su Hijo Jesucristo, Él asumió la naturaleza humana en su estructura integral. Dios no asumió una parte del hombre sino su totalidad. De modo que la Encarnación es el descenso de Dios a lo más profundo del ser humano para asumirla. Este descenso divino implicó salir Dios de sí mismo por su bondad y amor. Por lo tanto, es Él quien ha tomado la iniciativa para comunicarse y comunicar su plenitud al hombre. Igualmente, significa comunicación, que lo hace Dios por medio de su Palabra que humaniza al hombre. También es un encuentro entre la eternidad y el tiempo en un horizonte que densifica la persona de Jesucristo, Dios y Hombre.

Así mismo, en el progreso humano hacia su plenitud, Jesús es el maestro, el pedagogo de la humanidad. Más aún, Jesús como hombre y como Dios es viador y bienaventurado. Como lo señala el Aquinate: "Pero Cristo no fue sólo viador, sino también bienaventurado. $\mathrm{Y}$, por eso, es cabeza no sólo de los viadores, sino también de los bienaventurados, porque posee en grado plenísimo la gracia y la gloria" ${ }^{\text {"76 }}$. Así mismo, para el progreso humano son necesarias las virtudes morales y su perfeccionamiento por medio de las virtudes teologales, los sacramentos, los dones y los frutos de Espíritu Santo.

De hecho, Jesucristo es el modelo de humanidad a seguir: "Yo soy el camino, y la verdad, y la vida" ${ }^{477}$. Y en la pedagogía del seguimiento de Cristo la formación es una transformación en Jesucristo, verdadero Dios y verdadero Hombre, la luz que ilumina el camino de todo hombre en la tarea de hacerse hombre.

El proyecto Hombre ya sólo es posible por la unión con Jesucristo, mediante el seguimiento y la conformación con Él. El círculo de la salvación se extiende a todos los hombres en el curso de la historia. Nadie queda fuera de este proyecto de Dios. Todo hombre es capax Dei, pero sólo logra llegar a Dios por Jesucristo, Salvador de los hombres.

El ascenso humano se realiza en la medida en que nos asemejemos con la persona de Cristo. De modo que ascender humanamente conlleva el seguimiento de Jesús, la cristificación. Con Él la humanidad es llevada a su plenitud al asumir en la Encarnación la naturaleza humana. Pero la naturaleza humana no queda absorbida o anulada por la gracia de Dios, manifestada en la Encarnación. Por el contrario, ella se constituye en impulso hacia el fin último del hombre. De manera que el hombre retorna en el ascenso al estado original en cuanto es imagen de Cristo y participa de la vida divina. Ésta es la voluntad de

\footnotetext{
476 TomÁs DE AqUino. Suma de Teología, III, q. 8, a. 4, ad. 2.

477 Jn. 14, 6.
} 
Dios: "Dios quiere de nosotros es que el hombre sea restablecido al estado y dignidad en que fue creado el primer hombre" 478 .

En efecto, la Encarnación es la clave del nuevo humanismo educativo y el horizonte de comprensión del hombre en la cultura universitaria y en su proyecto humano de formar o hacer al hombre. La formación humanística desde la Encarnación es una pedagogía teológica, cuyo centro de formación es la persona humana. Como lo señaló el maestro Tomás de Aquino:

Debemos, pues, ver al hombre, después de los ángeles, como más digno que las demás creaturas, y no aminorar nuestra dignidad de ningún modo por el pecado o por el apetito desordenado de las cosas corpóreas, que son más viles o inferiores a nosotros y que han sido hechas para nuestro servicio; sino que debemos mantenernos en el modo en que nos hizo Dios $^{479}$.

\section{La formación sólida en tiempos líquidos}

Nos encontramos en un mundo caracterizado por cambios profundos, constantes y acelerados, que afectan la vida de las personas en todos sus sentidos y dimensiones. De modo que es fundamental educar "agentes de cambio", pero desde una formación sólida, lo que supone un alto componente moral, holístico o integral para hacer el hombre. Y una respuesta de formación sólida a esta situación de incertidumbre en la que se encuentra la cultura actual por los constantes cambios que desestabilizan todo proyecto encaminado a hacer el hombre, la hallamos en la formación humanística en clave encarnacional.

La formación humanística cristiana es integral por su comprensión del hombre tan única desde la Encarnación. Y lo es porque une o teje en un mismo horizonte lo humano y lo divino, que ninguna otra antropología puede ofrecer al hombre y que está encaminada a la formación humana como promotora de un nuevo humanismo: Facientes humanitatem, hacedora de la humanidad del hombre, cuya imagen o modelo es Jesucristo.

De manera que a la luz del facientes veritatem, del humanismo cristiano integral, se presentan siete principios o claves de una formación sólida en 'tiempos líquidos' ( $Z$. Bauman).

\footnotetext{
478 TOMÁs DE AQUINO. Exposición sobre la oración dominical, el Padrenuestro. Tercera petición: 'Hágase tu voluntad así en la tierra como en el cielo'.

${ }^{479}$ TOMÁs DE Aquino. Exposición del Símbolo de los Apóstoles, art. 1. 'Creo en un solo Dios Padre omnipotente, Creador del cielo y de la tierra'.
} 
Primer principio: pedagogía de la Humanización. El centro de la formación o de toda propuesta educativa es la persona humana. La enseñanza se encamina a hacer del hombre plenamente humano, a que aprenda a desarrollar todas las capacidades o facultades que por naturaleza se tienen. La humanización es un camino de conducción y promoción humana, de hacer del hombre una persona virtuosa, dueña de sus propios actos. De modo que si todas las personas se educaran en la virtud todas serían buenas y, por ende, buenos sus actos.

En este orden de ideas, humanizar al hombre es un proceso de enseñanza y de aprendizaje, de formación y transformación de la humanidad. Pero humanizar implica vivir la humanidad con una intensidad especial. Así mismo, el humanismo de la Encarnación es el proyecto de una nueva humanidad, abierta a la trascendencia que supera el falso dilema de contraponer a Dios y al hombre. Entonces descubrimos una pedagogía teológica integral desde la persona de Jesucristo, que es el Primer Hombre de esta nueva humanidad que nos muestra el camino de un auténtico humanismo, en el que lo humano y lo divino se encuentran.

Segundo principio: pedagogía del diálogo. Paradójicamente, en la cultura de la hipercomunicación se ha perdido el sentido que tiene el diálogo, la comunicación y el lenguaje en las relaciones de encuentro interpersonal. El diálogo acerca y respeta las opiniones entre personas y culturas diferentes. Más aún, el diálogo es una manera de crecer humanamente en sentido personal y comunitario. El hombre se hace en el diálogo porque es un ser social y político. De manera que sin diálogo no hay proceso de enseñanza- aprendizaje.

En un mundo globalizado e interconectado es necesario formar en la humanidad multicultural, y para esto es fundamental el diálogo. Multiculturalismo no significa un conjunto amorfo de retazos de diferentes culturas sino diálogo con todas las culturas, a partir de una cultura que se abre a las demás. Donde hace falta el diálogo se impone el autoritarismo y se tiende a desconocer lo demás. Desde la perspectiva de la pedagogía teológica integral la encarnación es un diálogo entre la eternidad y el tiempo. De manera que ser plenamente humano incluye la necesidad de complementarnos mutuamente, de intercambiar, de dar y recibir. 
Tercer principio: pedagogía de la verdad. La verdad se construye en comunidad. Así mismo, la verdad es hacedora de humanidad porque una generación es deudora de la anterior, de sus aportes y descubrimientos. Sin embargo, en la cultura actual el lugar de la verdad lo ocupa la opinión. Y esta situación hace que se pierda el sentido de enseñanza y construcción de la verdad, desaparezca el valor de durabilidad, de continuidad, aporte o construcción comunitaria. Hoy una generación no hereda ni quiere heredar ningún tesoro del saber. En un mundo cambiante se pierde la noción de conocimiento de la verdad útil para toda la vida a cambio de lo provisional y relativo.

En la pedagogía teológica, Jesús enseña a que la verdad libera al hombre de las ataduras y todo tipo de esclavitud ideológica humana que deshumaniza (Cf. Jn 8, 32). Una de las principales tareas de la formación humana y del hacerse hombre es la de enseñar a responder. De igual manera es importante una pedagogía de la respuesta en los procesos de formación. Porque cuando se enseña a responder se hace un hombre libre, responsable, autónomo y con convicciones profundas. El proceso de enseñanzaaprendizaje es un proceso de enseñar y aprender a dar respuesta por sí mismo, capaz de tomar opciones y decisiones. De modo que no hay que pedirle a los maestros que den respuesta sino que enseñen a responder. A preguntarnos y respondernos por nosotros mismos, por convicción propia y por amor, liberándonos día a día de toda imposición y de todo apego bloqueadores y enajenantes de nuestra primigenia capacidad de pregunta y de respuesta.

Cuarto principio: pedagogía de la compasión. En el mundo del consumismo, el de 'usar y tirar', se va perdiendo la sensibilidad humana. Así mismo, no hay compromiso ni corresponsabilidad por la vida de la otra persona. La 'ceguera moral' del hombre en la cultura contemporánea es la indiferencia humana. No obstante, el hacerse hombre es en comunidad, en compañía de sus semejantes, y siempre requiere de las relaciones mutuas y humanas, y no hay nada más humano que la compasión o el experimentar el dolor de nuestro semejante $y$ totalmente otro. Es importante enseñar y aprender a amar la humanidad y a compadecernos de ella, proteger y cuidar la dignidad de todo hombre.

El modelo pedagógico teológico enseña que Dios se ha compadecido de la humanidad. En la compasión Jesús le muestra al hombre su humanidad. En la mirada del Jesús se conoce la compasión de Dios, que no queda sin hacer nada ante lo que atenta contra la dignidad de la persona. Toda ley o norma del hombre debe tener como centro la vida humana. La 
compasión es promotora de humanidad, y en ella nace lo humano del hombre porque es salir de sí para asumir -como Jesucristo-, el dolor del otro.

Quinto principio: Pedagogía de la ciudadanía. El hombre es un amigo para el hombre. No obstante, al lema natural de vivencia o convivencia humana se opone el lema antihumanista licántropo, 'el hombre es un lobo para el hombre' (Plauto / Hobbes). La educación debe formar para la cultura ciudadana mundial, aprender a vivir juntos, que implica vivir experiencias concretas de contacto con lo diferente, de solidaridad, de respeto, y de responsabilidad con respecto al otro.

Ahora bien, la manera más humana de relacionarnos es la amistad. A nivel de la pedagogía teológica, Dios ha establecido una amistad con el hombre desde la Creación, pero de modo único con la persona de su Hijo Jesucristo. La filantropía es connatural en el hombre y, en comparación con los otros tipos de amistades humanas, es la más grande. La amistad humana se extiende a todos sus semejantes, sin importar la condición porque ante todo somos personas. La humanidad forma una gran familia porque somos conciudadanos del mundo. El hombre es un amigo para el hombre porque somos ciudadanos del mundo globalizado. La amistad es koinonía de la gran familia humana, es decir, la comunión mundial que se genera en la humanidad y que se encarna en los valores del diálogo, la inclusión, participación, compasión, caridad y solidaridad.

Sexto principio: Pedagogía del Bien Común. La vida en comunidad conduce a la realización de proyectos o fines comunes. Así mismo, para una sociedad alcanzar los fines es importante la cooperación de todas las personas que la componen. Sin embargo, al Bien Común se opone o la amenaza el individualismo y la corrupción. De manera que los intereses egocéntricos atentan contra el compromiso y la cooperación en el bien de todos. La corrupción por parte de quienes tienen la responsabilidad de orientar los intereses comunes y la atención a las necesidades particulares de las personas, trasgrede todo derecho humano a una vida en dignidad.

Por otra parte, la formación humana y en clave encarnacional se orienta al crecimiento personal pero en comunidad. Toda persona está llamada a servir a la humanidad, al Bien Común. El progreso humano y el desarrollo social involucran a todos los que la conforman. Se trata de una pedagogía de la inclusión y la participación de todos los miembros de la sociedad para la realización de proyectos humanos y humanizantes. De igual manera es fundamental humanizar las estructuras humanas para la promoción del Bien Común. 
Séptimo principio: pedagogía de la predicación. La relación del hombre con Dios es algo esencial que no se puede suprimir de la vida humana. El hombre es un ser social y político, pero además es un ser teologal. Afirmar a Dios y al hombre a la vez hoy se considera cada vez más incompatible en el mundo contemporáneo. Y la negación de Dios tiene como consecuencia la negación y la muerte del hombre, porque Dios es principio, fundamento y fin del hombre por ser creado a imagen y semejanza de Dios.

El nuevo humanismo del siglo XXI debe dar respuesta a establecer una correcta relación entre el hombre, Dios y el mundo. De ahí que sea importante crear ambientes en los que se facilite en encuentro con la persona de Jesús, que nos sigue mostrando el verdadero rostro de Dios y del hombre. El hombre es capaz de negar a Dios, pero mucho más de conocerlo y amarlo. La pedagogía del encuentro con la persona de Jesús se convierte en la experiencia cristiana fundante del seguimiento de Cristo, que nos invita a un nacer de nuevo, a una metanoia, es decir, conversión o radical transformación desde dentro.

En efecto, la tarea principal de todos los centros o lugares de formación es hacer al hombre plenamente humano. Sin embargo, ante las diferentes propuestas educativas y diversidad de humanismos, el humanismo en clave encarnacional responde a una formación integral de la persona para el siglo XXI. Por consiguiente, en la Encarnación se origina un nuevo humanismo y comprensión del hombre, una pedagogía teológica porque en Jesucristo conocemos el verdadero rostro de Dios y del hombre, a la luz del cual tenemos la responsabilidad de re-crear al hombre. 


\section{CONCLUSIÓN}

El pensador dominico y español fray Abelardo Lobato Casado, O.P., es uno de los mejores conocedores y exponentes de Santo Tomás de Aquino y de su doctrina tomista en el presente siglo. La incidencia del pensamiento tomista en él fue fundamental para crear y desarrollar su propia doctrina. En los escritos de Lobato son abundantes y diversos los temas abordados, y presenta como referente al Aquinate.

Lobato se caracterizó por ser un dominico, discípulo de Santo Tomás y un humanista. Como dominico vivió el carisma de la predicación de la verdad a través de la enseñanza o docencia, como lo evidenció la itinerancia de sus múltiples viajes a diferentes países donde fue invitado para tratar temas o problemas de actualidad. Como discípulo del Aquinate se dedicó de tiempo completo al estudio de su pensamiento, de sus fuentes, en su contexto histórico, de tal manera que tenía una visión profunda de su pensamiento. Además, sobresalió en la difusión de la doctrina tomista con su enseñanza y diversos estudios y artículos dedicados a temas de Santo Tomás. Finalmente, al diálogo entre Tomás de Aquino y la cultura actual. Esto último lo logró porque estuvo atento a la problemática actual y la iluminó a la luz del 'sol de Aquino'. Como humanista se interesó por el humanismo del hombre y su dignidad, en tanto el hombre es un ser digno por naturaleza, pero también una aventura humana que se conquista o también se pierde.

Uno de los problemas actuales que trató Abelardo Lobato fue la comprensión del hombre, para cuyo abordaje conoció y estudió de cerca los diferentes estudios de la antropología contemporánea, y encontró en ellos la diversidad en la manera de comprender al hombre, si bien vio varios de esos estudios inconexos y contrapuestos. De manera que creó y desarrolló una nueva comprensión del hombre llamada mentantropología -en virtud de su fundamentación metafísica-, a través de la cual buscó superar la complejidad del hombre e integrar las diversas y contradictorias antropologías actuales. De igual manera, desde esta comprensión metantropológica del hombre ayudó a la superación de los olvidos radicales de la cultura contemporánea, de los cuales señaló fundamentalmente cinco: el olvido del ser, el olvido de Dios, el olvido del alma, de la inteligencia y de la virtud.

A Abelardo Lobato se le puede considerar como un profeta o un filósofo de la anámnesis o de la memoria en una cultura que se caracteriza por el olvido, por la ruptura con el pasado, sin referentes y pedagogos. No obstante, Abelardo buscó horizontes de comprensión a los 
diferentes problemas que el hombre de hoy afronta, y los trata desde fundamentos sólidos, de manera crítica y diáfana.

De ahí el desarrollo investigativo que estamos implementando de la metantropología en el pensamiento lobatiano para la comprensión del humanismo cristiano en el contexto de la Universidad Santo Tomás en Colombia. Por eso se ha planteado la pregunta de esta investigación: ¿De qué manera la comprensión del hombre desde la metantropología en Abelardo Lobato posibilita un horizonte de conceptualización del humanismo cristiano en el contexto universitario? Así mismo, a la pregunta planteada se ha propuesto la hipótesis siguiente: El pensamiento lobatiano está orientado a la constitución y desarrollo de la metantropología. A todas luces, su comprensión permitiría la construcción de un horizonte de conceptualización del humanismo cristiano en el contexto propio de la Universidad Santo Tomás de Colombia.

Para responder a la pregunta planteada y a la hipótesis propuesta se establecieron las siguientes consideraciones:

Primera: sobre el pensamiento de Abelardo Lobato se ha realizado una investigación sobre su concepción de dignidad humana. Sin embargo, se han realizado estudios sobre su vida, escritos y de manera general, y de los principales temas tratados en su obra. Se ha resaltado la incidencia que tuvo el pensamiento tomista en la doctrina y enseñanza del pensador dominico, al punto que él mismo llega a considerar que el Aquinate es la fuente fundamental de su pensamiento. La originalidad del pensamiento lobatiano radica en la creación del concepto de mentantropología y su desarrollo, el cual articula con todo los temas abordados.

Segunda: para Lobato el principal problema de la cultura contemporánea es el olvido, que él amplifica como una cultura sin memoria. Pero no se trata de cualquier tipo de olvidos, sino radicales, porque afectan la estructura antropológica del hombre, en su ser y hacer. Esto ha sucedido porque las principales teorías del pensamiento contemporáneo han significado ruptura, desprendimiento de los pedagogos, entre ellos Dios, la familia, los maestros, y todo proceso pedagógico de acompañamiento hacia la madurez. Por lo tanto, Abelardo Lobato consideró que era importante recuperar la memoria de los olvidos radicales a los que ha llegado el hombre de hoy. Es urgente volver y recuperar la memoria del ser ante el nihilismo, la memoria de la fe en Dios ante el ateísmo, la memoria del alma o de una antropología integral ante su atomización; memoria de la verdad ante su 
relativismo; y memoria de la virtud ante una ceguera moral o simplemente anclada en lo provisional.

Tercera: Lobato fue un estudioso de Santo Tomás de Aquino y al mismo tiempo de la humanidad del hombre. Así mismo, los temas de interés y de investigación que compusieron su obra y pensamiento fueron abundantes y de diferente índole. Todos ellos conformaron sus ideas constantes y reflexiones propias dentro de un sistema de pensamiento bajo el nombre de su autor, que lo hemos llamado: Pensamiento Lobatiano. Todas sus investigaciones conducen a la comprensión metantropológica del hombre. De igual manera son una respuesta a los olvidos radicales de la cultura contemporánea, propuesta que ha tenido como fuente de iluminación el pensamiento tomista.

Cuarta: en Abelardo Lobato la referencia al maestro Tomás de Aquino está presente en toda su obra y su perspectiva humanista. Así mismo, la imagen que asume Lobato de santo Tomás es la del teólogo y humanista que van a incidir en su personalidad. Pero, en últimas, el enfoque del humanismo del Aquinate -como el de Lobato- es la del humanismo cristiano. De modo que, si su punto de partida del horizonte intelectual fue la metantropología, a partir de donde trata de dar respuesta a los olvidos radicales del hombre de hoy, el punto de llegada debe ser la persona de Cristo como modelo del Hombre y de la nueva Humanidad. La vida humana es ascenso hasta la configuración con Jesucristo, verdadero Dios y verdadero hombre.

Quinta: desde la concepción metantropológica como horizonte de conceptualización del humanismo cristiano en Abelardo Lobato -en el contexto universitario de la Universidad Santo Tomás de Colombia-, se ha concebido y desarrollado la expresión Facientes Humanitatis, es decir, la universidad como hacedora de humanidad. Así mismo, la universidad de carácter cristiana-católica-tomista en el siglo XXI asume la tarea de hacer el hombre en clave encarnacional, desde la persona de Jesucristo como paradigma de la nueva humanidad.

En el contexto de la Universidad Santo Tomás de Colombia se ha llegado a determinar que tiene una fundamentación humanista cristiana muy bien definida en los documentos institucionales, de inspiración humanista. No obstante, muy poco desarrollado y vivido en la experiencia de la cultura universitario de los jóvenes tomasinos. 
Los estudiantes tomasinos tienden a comprender la formación más en clave profesional que humanista. Sin embargo, persiste un compromiso profesional con los problemas e interrogantes en el contexto local y nacional. Pero esto no garantiza una formación humanística. Aunque sucede todo lo contrario: la formación humanística de los estudios sí garantiza una formación de calidad y profesional.

El Departamento de Humanidades y Formación Integral debe articular más las materias y cursos con miras a la formación humanista a la profesional. Los estudiantes tomasinos, si bien para algunos han sido importantes las Humanidades en la vida personal y profesional, para muchos son materias que no se relacionan con su carrera universitaria. 


\section{RECOMENDACIONES}

Dentro de las recomendaciones que se pueden trazar a partir de esta investigación se contemplan las siguientes:

- Tendría un gran interés y sería de gran utilidad que se comenzara a preparar y a editar las Obras Completas de Abelardo Lobato. Para la Universidad Santo Tomás sería interesante tomar esa iniciativa, ya que se inspiran en el humanismo cristiano según Santo Tomás de Aquino, y Abelardo Lobato lo desarrolla muy bien en su vida y obra.

- Para el Departamento de Humanidades y Formación Integral de la Universidad Santo Tomás es importante inculcar en sus maestros el Pensamiento Lobatiano como una aproximación al tomismo y al humanismo cristiano, tan propicios para el claustro docente.

- Para futuras investigaciones sobre el Pensamiento Lobatiano se hace necesario desarrollar más el tema de los Derechos Humanos en el contexto de violencia que se vive hoy a nivel mundial, continental, nacional y regional. 


\section{BIBLIOGRAFÍA}

a). Fuentes primarias:

LOBATO, A. "El sentido moral en situación de peligro en la cultura contemporánea". Angelicum, Vol. 72 (1995), pp. 3-12.

. "La dignidad del hombre en Santo Tomás de Aquino". Carthaginensia. Vol. 6 (1990), núm. 9, pp. 139-153.

. "Afirmación de Dios, confirmación del hombre". Communio, Vol. 23 (1990), pp. 3-30.

. "Los Derechos Humanos en el pensamiento contemporáneo". Verbo. (1980), núm. 189-190, pp. 1171-1197.

. "Antropología y metantropología: Los caminos actuales de acceso al hombre". En: Antropologia e Cristologia ieri e oggi. Atti del Convegno di Studio della SITA. Roma: Pontificia Universitá S. Tommaso D’Aquino, 1987, pp. 175-211.

. "Nuevos horizontes de los Derechos Humanos: La Iglesia y los derechos de los pueblos". Angelicum Vol. 73, (1996), pp. 186-216.

Santo Tomás, arquitecto de la vida universitaria: El profesor ideal de la paideia tomista. Bogotá : Universidad Santo Tomás, 2002, pp. 57.

- "La paideia cristiana de la libertad en relación interpersonal". Sophia, Colección de Filosofía de la Educación (2007), núm. 3, pp. 33-76.

"Experiencia de Dios y palabra humana en Teresa de Jesús". Angelicum. Vol. 59 (1982), núm. 1, pp. 323-354.

"La paideia cristiana de la libertad en relación interpersonal". Sophia, Colección de Filosofía de la Educación. 2007, núm. 3. pp. 33-76.

"La Orden de Predicadores y su misión doctrinal". Communio, (2001), Vol. 34, pp. 263-287. 
"La familia y la Communio Personarum". En: Higinio Marín Pedreño (Coord.). Actas del Congreso Internacional. Educación, Familia y Vida. Murcia : Universidad Católica San Antonio, 2002, pp. 17-38.

. "Maimónides, Averroes y Tomás de Aquino: Diálogo de tres culturas". Communio, Vol. 19 (1986), pp.7-23.

. "El sentido moral en situación de peligro en la cultura contemporánea". Angelicum. Vol. 72 (1995), pp. 3-12.

"La paideia exigida por la verdad". En: Robert Christian, O.P. (Eds.). La formazione integrale domenicana. Bologna: 1996, pp. 273-292.

. "La verdad como conquista humana". En: Sapientia Aquinatis. Relationes Communicationes et Acta IV Congressus Thomistici Internationalis. Roma: 1956, pp. 205211.

. "La verdad integral sobre el hombre: La antropología tomista". E-aquinas (2006), núm. 7, pp. 2-9.

"El lenguaje y la palabra en Tomás de Aquino". Revista de filosofía. (1989), núm. 65, pp. 2-9.

. "La filosofía de santo Tomás de Aquino y su estructura dialógica". Angelicum (1984), núm. 61, pp. 63-95.

. "La dignidad del hombre en santo Tomás de Aquino". Carthaginensia. Vol. 6 (1990), núm. 9, pp. 51-82.

. "La dignidad del hombre y los Derechos Humanos". Studium, Vol. 22, (1982), fasc. 1, pp. 71-105.

. "El horizonte estético del hombre medieval: La perspectiva tomista". Revista Española de Filosofía Medieval. (1999), núm. 6, pp. 57-68.

. "Dic mihi, quid est Deus? Diálogo y disputa de Tomás de Aquino con Averroes y Maimónides en torno al monoteísmo". Communio (1998), núm. 2, pp. 225-251. 
"El hombre, síntesis de la creación”. En: José M. Petit Sullá - José M. Romero Baró (Eds.). Actas del Congreso: La sintesis de santo Tomás de Aquino. Barcelona: Publicacions i edicions de la Universitat de Barcelona, 2002, pp. 121-138.

"La aportación de los Dominicos en el Siglo XVI a la defensa y promoción del hombre”. Angelicum. Vol. 70 (1993), pp. 363-415.

Santo Tomás de Aquino: Maestro de maestros. Burgos, España: Monte Carmelo, 2006, pp. 118.

Juan Pablo II y santo Tomás 'Doctor Humanitatis'. Milano, Italia: Studia Universitatis S. Thomae in Urbe, 1991, pp. 32.

. Abelardo, haz memoria: Las obras y los días. Valencia (España) : EDICEP, 2011, pp. 646.

. Dignidad y aventura humana. Salamanca (España) : Edibesa, 1997, 273 p.

. "Tomás de Aquino, modelos de quienes buscan la verdad". Ius Publicum. (2002), núm. 8, pp. 23-45.

. "La persona en Santo Tomás de Aquino". Ius Públicum. (2001), núm. 6, pp. $11-31$.

Ser y belleza. Barcelona (España) : Herder, 146 p.

. "El silencio de Dios y el Dios del silencio". Communio, Vol. 32 (1999), núm. 2, pp. 273-297.

. "El hombre a la luz del misterio de Cristo". En: LOBATO, A. (Dir.) y otros. El pensamiento de Santo Tomás de Aquino para el hombre de hoy. Vol. II, El hombre, Jesucristo y la Iglesia. Valencia (España) : EDICEP, 2007, pp. 23-44.

"Jesucristo y el proyecto Hombre". En: A. LOBATO, O.P. (ED), Actas del IV Congreso Internacional de la S.I.T.A. Tomo I, Ponencias. Córdoba (España) : Publicaciones Obra Social y Cultura Cajasur, 1999, pp. 297-312. 
"La mujer y el varón cara a cara: El problema de la diferencia". Angelicum, Vol. 72, (1995), pp. 541-577.

. "El humanismo de la ley según Santo Tomás. Verbo (1977), Nos. 151-152,

pp. $79-88$.

b). Fuentes secundarias:

BAUMAN, Zygmunt (2015). Vida líquida. Barcelona : Paidós, 201 p.

(2005). Amor líquido: Acerca de la fragilidad de los vínculos humanos.

México D. F. : Fondo de Cultura Económica, 201 p. (2008). Los retos de la educación en la modernidad líquida. Barcelona

: Gedisa, 46 p.

BECK, Ulrich (2008). La sociedad del riesgo mundial: En busca de la seguridad perdida. Barcelona : Paidós, $333 \mathrm{p}$.

CANOBBIO, Giacomo (2010). Sobre el alma: Más allá de la mente y el cerebro. Salamanca (España) : Sígueme.

CÁRDENAS PATIÑO, Alberto (2009). La Universidad Santo Tomás de Colombia ante su historia: Siglos XIX-XX: voluntad de persistencia. En: El proyecto educativo del último secretario de la tomística. Bogotá : Universidad Santo Tomás. 483 p.

FEUERBACH, Ludwig (1975). La esencia del cristianismo. Salamanca (España) : Sígueme. $375 \mathrm{p}$.

FICHTE, Johann Gottlieb (2013). El destino del hombre. Madrid : Gredos. 896 p.

FREUD, Sigmund (1968). Psicopatología de la vida cotidiana. En: Obras Completas, Vol. I. Traducción directa del alemán por Luis López-Ballesteros y de Torres. Madrid: Biblioteca Nueva.

HAN, Byung-Chul (2014). En el enjambre. Barcelona : Herder. 109 p. (2015).Psicopolítica: Neoliberalismo y nuevas formas de poder.

Barcelona : Herder. 127 p. 
JÁUREGUI MADOZ, Vicente (1997). 10 palabras clave sobre los miedos del hombre moderno. Pamplona (España) : Verbo Divino. 350 p.

KANT, Inmmanuel (2010). Contestación a la pregunta: ¿Qué es la ilustración? Madrid : Gredos, Vol. II.

LIPOVETSKY, Gilles (2003). La era del vacío. Barcelona : Anagrama. 220 p.

(2007). La felicidad paradójica. Barcelona : Anagrama. 399 p.

MARX, Karl (2012). El fundamento de la crítica. Madrid: Gredos. 675 p.

NIETZSCHE, Friedrich (2004). Así habló Zaratustra. Madrid : Edimat Libros, S. A. 634 p.

PLATA, William E. (2005). "La universidad Santo Tomás de Colombia ante su historia: siglos XVI-XIX”. En: Nacimiento del estudio conventual. Bogotá : Universidad Santo Tomás. $492 \mathrm{p}$.

SCHILLEBEECKX, Edward, O. P. (1969). El mundo y la Iglesia. Salamanca (España) : Sígueme. $453 \mathrm{p}$.

Tomás DE AQUINO, (2010). Suma de Teología. 5 Tomos. Madrid : BAC. . (2007). Suma contra Gentiles. 2 Tomos. Madrid : BAC. (2001). Comentario a la Política de Aristóteles. Navarra (España) : EUNSA, $680 \mathrm{p}$. (2003). Opúsculos y cuestiones selectas. Tomo II (Teología 2). Q. D., sobre el mal. Madrid : BAC.

(2003). Opúsculos y cuestiones selectas. Tomo II (Teología 2). Exposición del Símbolo de los Apóstoles. Madrid : BAC.

(2003). Opúsculos y cuestiones selectas. Tomo II (Teología 2). Exposición sobre la oración dominical, el Padrenuestro. Madrid : BAC.

(2001). Opúsculos y cuestiones selectas. Tomo I (Filosofía 1). Q. D., de las Creaturas Espirituales. Madrid : BAC. 
(2001). Opúsculos y cuestiones selectas. Tomo I (Filosofía 1). Q. D., sobre la verdad. Madrid : BAC.

(2003). Opúsculos y cuestiones selectas. Tomo II (Filosofía 2). La Monarquía: Al Rey de Chipre. Madrid : BAC.

(2002). Comentario al libro de Aristóteles sobre el cielo y el mundo. Navarra (España) : EUNSA 540 p.

. (2002). Comentario a las Sentencias de Pedro Lombardo. Volumen I /

1. El misterio de la Trinidad. Navarra (España) : EUNSA, 640 p. 


\section{ANEXO I}

\begin{tabular}{|c|c|c|c|}
\hline \multicolumn{4}{|c|}{$\begin{array}{c}\text { Universitat Abat Oliba CEU } \\
\text { Doctorado en Estudios Tomísticos } \\
\text { Propuesta de tesis doctoral }\end{array}$} \\
\hline 1. Titulo: & \multicolumn{3}{|c|}{$\begin{array}{l}\text { Antropología y metantropología en Abelardo Lobato: nuevo horizonte de comprensión del humanismo cristiano en el contexto de la } \\
\text { Universidad Santo Tomas - Colombia }\end{array}$} \\
\hline $\begin{array}{l}\text { 2. Pregunta de } \\
\text { investigación: }\end{array}$ & \multicolumn{3}{|c|}{$\begin{array}{l}\text { ¿De qué manera la comprension del hombre desde la metantropología en Abelardo Lobato posibilita un horizonte de conceptualización del } \\
\text { humanismo cristiano en el contexto universitario? }\end{array}$} \\
\hline 3. Objetivo general: & \multicolumn{3}{|c|}{$\begin{array}{l}\text { Trazar derroteros que permitan la comprensión de la metantropología en Abelardo Lobato para un horizonte de conceptualización del } \\
\text { humanismo cristiano en el contexto universitario. }\end{array}$} \\
\hline \multirow{5}{*}{$\begin{array}{l}\text { 3.1. Objetivos } \\
\text { especificos: }\end{array}$} & \multicolumn{3}{|c|}{$\begin{array}{l}\text { Señalar los principales estudios e investigaciones que se han realizado sobre la vida y obra de Abelardo Lobato y de manera sintética los } \\
\text { insumos fundamentales del pensamiento de Tomás de Aquino que Lobato articula a su enseñanza. }\end{array}$} \\
\hline & \multicolumn{3}{|c|}{$\begin{array}{l}\text { Describir las teorías principales que orientan el pensamiento contemporáneo frente a las que Abelardo Lobato trata de dar respuesta a } \\
\text { través de sus escritos y enseñanza. }\end{array}$} \\
\hline & \multicolumn{3}{|c|}{ Identificar los constructos categoriales humanistas en el Pensamiento Lobatiano. } \\
\hline & \multicolumn{3}{|c|}{$\begin{array}{l}\text { Analizar los constructos epistemológicos en torno a la concepción de metantropología en Abelardo Lobato, que permitan la comprensión } \\
\text { del humanismo cristiano. }\end{array}$} \\
\hline & \multicolumn{3}{|c|}{$\begin{array}{l}\text { Interpretar la concepción de metantropología como horizonte de conceptualización del humanismo cristiano en Abelardo Lobato en el } \\
\text { contexto de la Universidad Santo Tomás de Colombia. }\end{array}$} \\
\hline 4. Hipótesis: & 5. Enfoque: & 6. Método: & 7. Ténica / Herramienta: \\
\hline \multirow{3}{*}{$\begin{array}{l}\text { El Pensamiento } \\
\text { Lobatiano está orientado } \\
\text { a la constitución y } \\
\text { desarrollo de la } \\
\text { metantropología. Su } \\
\text { comprensión permitiria la } \\
\text { construcción de un } \\
\text { horizonterar de } \\
\text { conceptualización del } \\
\text { humanismo cristiano en } \\
\text { el contexto propio de la } \\
\text { Universidad Santo } \\
\text { Tomás de Colombia. }\end{array}$} & $\begin{array}{l}\text { Cualitativo: observación } \\
\text { descripción y comprensión } \\
\text { del fenómeno. }\end{array}$ & Teoría fundamentada. & Encuesta / cuestionario. \\
\hline & 8. Categorías: & 9. Contexto: & 10. Población / muestra: \\
\hline & $\begin{array}{ll}\text { - } & \text { Metantropología } \\
\text { - } & \text { Humanismo } \\
\text { - } & \text { Cristiano } \\
\text { - } & \text { Formalidad } \\
\text { - } & \text { Tomismo }\end{array}$ & $\begin{array}{l}\text { Universidad Santo Tomás - } \\
\text { Colombia. }\end{array}$ & $\begin{array}{l}\text { Estudiantes de distintos programas que adelantan asignaturas } \\
\text { propias del Departamento de Humanidades y Formación Integral } \\
\text { de la USTA } \\
\text { Muestra: } 500 \text { estudiantes seleccionados en las diferentes Sedes y } \\
\text { Seccionales de la USTA Colombia. }\end{array}$ \\
\hline
\end{tabular}




\section{ANEXO II}

\section{UNIVERSITAT ABAT OLIBA CEU Barcelona - España}

Doctorado en Estudios Tomísticos

Encuesta a estudiantes de la Universidad Santo Tomás

UNIVERSIDAD SANTO TOMÁS

'Primer Claustro Universitario de Colombia'

La presente encuesta se realiza como instrumento académico y de investigación propio de la propuesta del trabajo intitulado: Antropología y Metantropología en Abelardo Lobato: Nuevo horizonte de comprensión del humanismo cristiano en el contexto universitario, con el propósito fundamental de conocer y analizar la cultura universitaria de la Universidad Santo Tomás de Colombia.

Lea cuidadosamente las siguientes preguntas relacionadas desde los componentes del Humanismo Cristiano Tomista de la USTA y del pensador dominico Abelardo Lobato, y elija una sola alternativa.

Si su respuesta es "Otros", por favor amplíe la información para mayor claridad.

Fecha límite de entrega: 17 de marzo de 2017

*Obligatorio

Marcar con una $X$ o responder.

\section{DATOS GENERALES}

1. FECHA*

2. GENERO.*

- Masculino.

○ Femenino.

3. EDAD.*

4. FACULTAD. *

5. SEMESTRE. *

6. SEDE / SECCIONAL.*

- Sede Principal Bogotá. 
- Sede Medellín.

- Sede Villavicencio.

- Seccional Bucaramanga.

- Seccional Tunja.

\section{UNIVERSIDAD Y FORMACIÓN HUMANA}

7. Para usted, ¿qué es la Universidad? *

a. Un lugar donde se crea conocimiento científico.

b. Un lugar para la humanización del hombre.

c. Una Institución donde se enseñan saberes especializados.

Otros:

8. ¿Conoce usted el modelo educativo y pedagógico de la Universidad Santo Tomás?*

Sí.

No.

9. ¿Cuál es el fin de la educación en la Universidad Santo Tomás?*

a. La adquisición de nuevos aprendizajes o conocimientos.

b. La conducción y promoción de la persona al estado perfecto del Hombre en cuanto el hombre, el estado de virtud.

c. La educación de los futuros profesionales del país.

Otros:

10. ¿Cuál es el modelo pedagógico de la Universidad Santo Tomás?*

a. Es 'magistrocentrista', es decir, centrado en la enseñanza y saberes del maestro.

b. Es 'paidocentrista', es decir, centrada en autoaprendizaje del alumno con la compañía del maestro.

c. Es un diálogo y proceso en el que se construye el saber entre el maestro y alumno.

Otros:

11. En su opinión, la Universidad del sigo XXI debe educar a los jóvenes universitarios para:*

a. El Bien Común.

b. La libertad.

c. El humanismo. 
Otros:

12. ¿Por qué?

13. ¿Los cursos o materias de la línea del Departamento de Humanidades y Formación Integral le han servido para el proyecto de vida personal y profesional?*

- Sí.

○ No.

14. ¿Por qué?

15. 7. ¿Sabía usted que la Universidad Santo Tomás se inspira en el pensamiento humanista cristiano de Santo Tomás?*

- Sí.

○ No.

16. Para usted, ¿qué significa el concepto 'humanismo cristiano'?*

a. Que todo gira alrededor del hombre, es decir, el hombre es el centro de todo.

b. Ascenso o crecimiento del hombre a través del desarrollo de todas sus facultades con la ayuda de Dios.

c. El hombre puede realizarse por sí mismo sin la ayuda de nadie.

Otros:

17. ¿Por qué?

18. ¿De qué manera para usted se manifiesta el humanismo en la universidad?:*

a. En el respeto hacia la manera pensar y creer la otra persona.

b. En la manera mutua de relacionarse todas las personas en la universidad sin importar su creencia, pensamiento, profesión o estrato social.

Otros:

19. ¿Sabía usted que la Universidad Santo Tomás es de confesión cristiana-católica?:*

- Sí.

○ No. 
20. ¿Qué importancia tiene para usted la confesión cristiana-católica de la Universidad Santo Tomás USTA en la formación profesional?*
a. Ninguna.
b. Hace parte de la formación integral de la persona.
c. Para relacionar fe y razón e integrarlas en la vida personal.

Otros:

\section{HUMANIDADES, CONTEXTO Y FORMACIÓN}

21. ¿Han sido importantes para su formación humana y profesional los cursos del Departamento de Humanidades y Formación Integral?:*
- Si
- No

22. ¿Por qué?

23. ¿Profesa usted algún credo o religión?*
- Sí.
- No.

24. Para usted, uno de los problemas más graves que afronta el hombre en la cultura actual es:*
a. El olvido de Dios.
b. La búsqueda de sentido de la vida.
c. El buscar y decir la verdad.
d. La práctica de las virtudes humanas.

Otros:

25. ¿Por qué?

26. 15. Considera usted que Dios*

a. Está presente en la historia de la humanidad.

b. Solamente en la oración y los sacramentos de la Iglesia.

c. Está ausente de los acontecimientos humanos.

Otros: 
27. Desde las diferentes asignaturas del Departamento de Humanidades y Formación Integral de la Universidad Santo Tomás, ¿cuál es la mejor comprensión del hombre?*

a. El hombre es solamente alma, y es lo más importante.

b. El hombre es fundamentalmente corporeidad.

c. El hombre es una unidad substancial de alma y cuerpo.

Otros:

28. En su opinión, el hombre en sus relaciones interpersonales es:*

a. Un ser sociable y político.

b. 'Un lobo para el hombre'.

c. Un amigo para el hombre.

Otros:

29. La verdad es un valor fundamental en la vida del hombre. En su opinión:*

a. La verdad no existe.

b. La verdad es relativa.

c. La verdad se busca y se construye.

Otros:

30. ¿Por qué?

31. Para usted, ¿En qué virtudes el hombre debería ser fundamentalmente educado?*

a. En las virtudes intelectuales.

b. En las virtudes morales de la prudencia, la justicia, la fortaleza y la templanza.

c. En las virtudes artística o técnica.

Otros:

32. ¿Cuál ha sido el valor central que ha cultivado en el contexto universitario y profesional?*

a. La verdad.

b. La libertad.

c. Justicia.

Otros: 


\section{SOCIEDAD, PERSONA Y CULTURA}

33. La dignidad de la persona proviene, en su opinión:*

a. Por naturaleza, por el hecho de ser persona.

b. Por ser imagen y semejanza de Dios.

c. Por los cargos que ocupa y bienes materiales

Otros:

34. ¿Qué actos considera usted que atentan más en su contexto social contra la pérdida de la dignidad humana?*

a. Las drogas alucinógenas.

b. El conflicto armado.

c. La corrupción.

Otros:

35. En su opinión, ¿cómo se puede definir la familia humana?*

a. La unión de hombre y mujer e hijos.

b. El conjunto de personas de un mismo sexo e hijos.

c. Todas las anteriores.

Otros:

36. ¿Qué medio usted utiliza más para comunicarse?*

a. Facebook.

b. El lenguaje humano directo.

c. Whatsapp.

Otros:

37. ¿En qué ámbito social influye más el medio de comunicación elegido?*

a. En el familiar.

b. En las relaciones de amistad.

c. En el académico.

Otros: 